\title{
PROBLEMY PRACY W KONCEPCJACH PROGRAMOWYCH DELEGATURY RZĄDU NA KRAJ (1941-1945)
}





\section{WAC $Ł A W ~ S Z U B E R T$}

\section{PROBLEMY PRACY \\ W KONCEPCJACH PROGRAMOWYCH \\ DELEGATURY RZĄDU NA KRAJ}

$$
\text { (1941-1945) }
$$

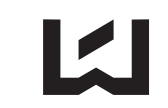

WYDAWNICTWO 
RECENZENT

Zbigniew Góral

REDAKTOR NAUKOWY

Michat Seweryński

REDAKTOR WYDAWNICTWA UŁ

Iwona Gos

SKŁAD KOMPUTEROWY

ESUS - Agnieszka Buszewska

PROJEKT OKŁADKI

Barbara Grzejszczak

Fotografia profesora Wacława Szuberta pochodzi ze zbiorów rodzinnych Autora

(C) Copyright by Uniwersytet Łódzki, Łódź 2012

Wydane przez Wydawnictwo Uniwersytetu Łódzkiego

Wydanie I. 5090/2012

ISBN 978-83-7525-745-8

Wydawnictwo Uniwersytetu Łódzkiego

90-131 Łódź, ul. Lindleya 8

www.wydawnictwo.uni.lodz.pl

e-mail: ksiegarnia@uni.lodz.pl

tel. (42) 66558 63, faks (42) 6655862 


\section{Spis treści}

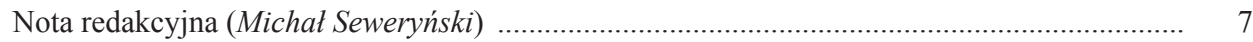

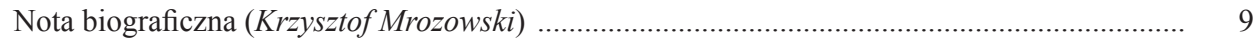

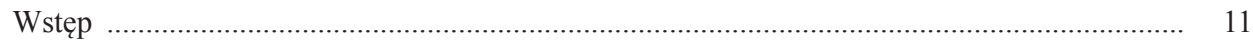

\section{CZĘŚĆ PIERWSZA}

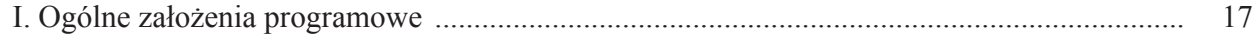

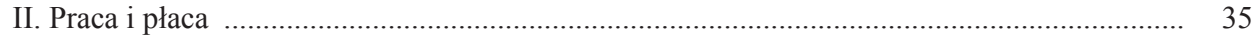

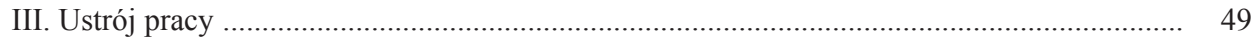

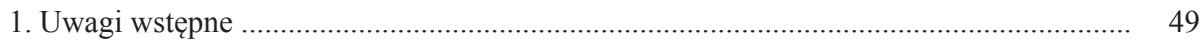

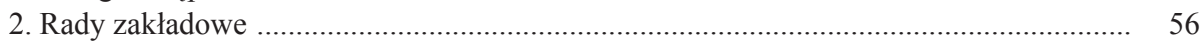

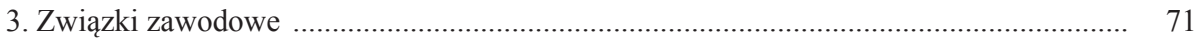

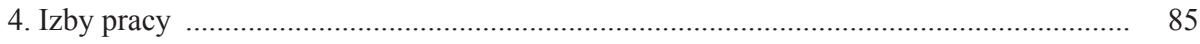

5. Idea samorządu społeczno-gospodarczego …….......................................................... 97

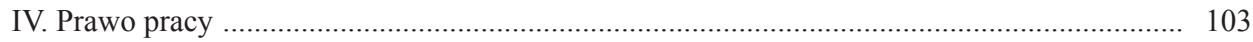

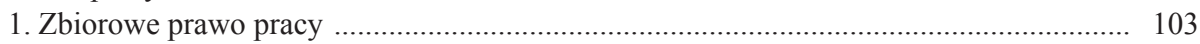

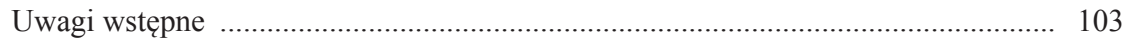

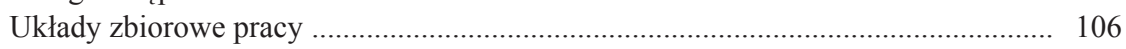

Pojednawstwo i rozjemstwo ..................................................................... 110

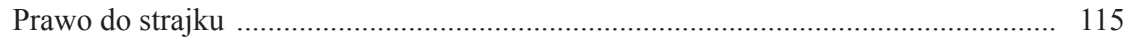

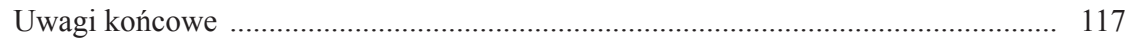

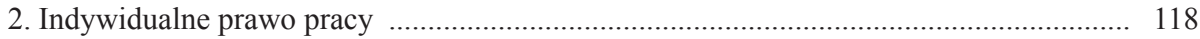

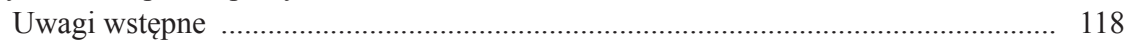

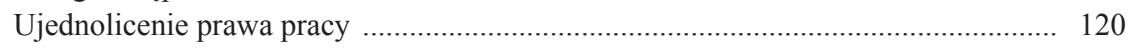

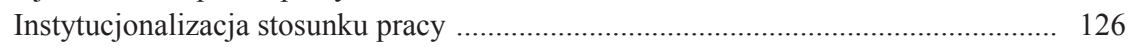

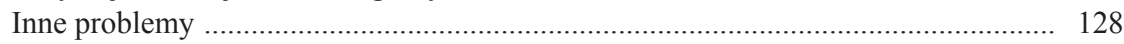

Uwagi końcowe .......................................................................................... 129

\section{CZĘŚĆ DRUGA}

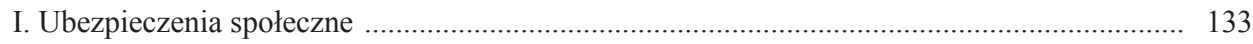

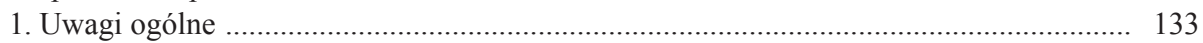

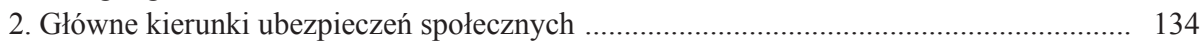

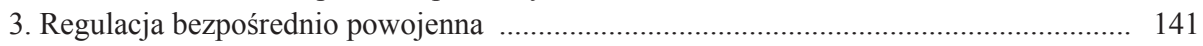

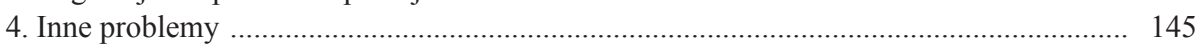

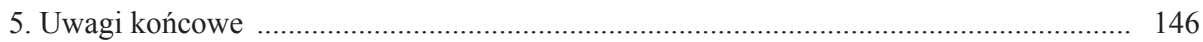




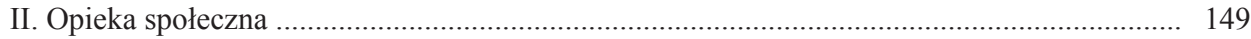

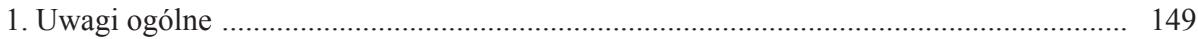

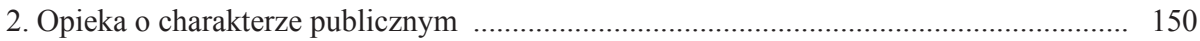

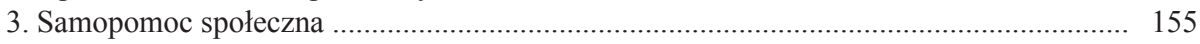

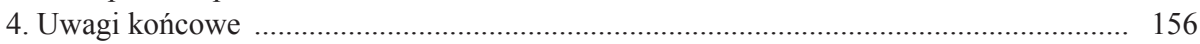

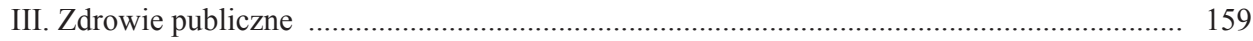

IV. Struktura administracyjna Departamentu i plany prac naukowych .................................. 165

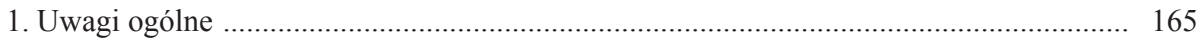

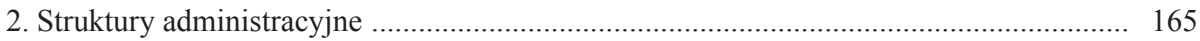

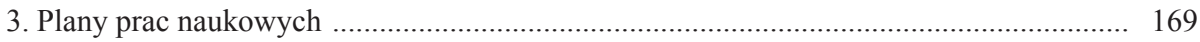

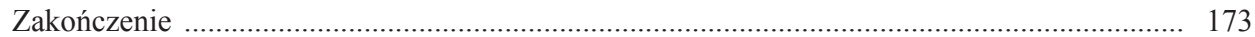

Aneks I. Wacław Szubert, Departament Pracy i Polityki Społecznej Delegatury Rządu (1941-1945) - organizacja i działalność ................................................................... 181

Aneks II. Wacław Szubert, Wspomnienia o Departamencie Pracy i Opieki Społecznej

Delegatury Rządu (1941-1944) ................................................................................ 201

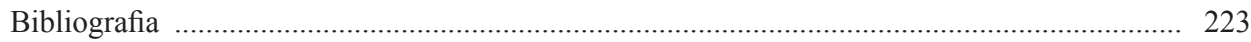




\section{Nota redakcyjna}

Maszynopis książki został odnaleziony i wstępnie opracowany w $2011 \mathrm{r}$. przez Rodzinę profesora Wacława Szuberta. Za jej zgodą uczniowie profesora postanowili wydać tekst drukiem. Na istnienie maszynopisu niniejszej książki wskazywała wypowiedź profesora Juliusza Bardacha, zamieszczona w opublikowanym przezeń artykule Wactaw Szubert o historii prawa i myśli społecznej („Czasopismo Prawno-Historyczne” 1994, t. XLVI, z. 120). Profesor J. Bardach pisał: „W ostatnich latach życia zajął się On problematyką pracy w działalności naczelnych władz państwa podziemnego. Przygotowywał monografię, którą zatytułował: Problemy pracy $w$ koncepcjach programowych Delegatury Rzadu (1941-1944). Pięć rozdziałów, już napisanych, obejmuje wraz z przypisami, 199 stron maszynopisu". Profesor W. Szubert zdążył pracę ukończyć, ale nie zdążył jej opublikować. Powstawała ona prawdopodobnie na przełomie lat osiemdziesiątych i dziewięćdziesiątych minionego wieku, o czym świadczą poczynione w tekście odesłania do ówczesnego piśmiennictwa oraz wzmianka Autora zamieszczona na początku Wspomnień o Departamencie Pracy i Opieki Społecznej Delegatury Rządu (1941-1944), zawartych w aneksie II. Uczniowie domyślali się, że taka książka powstaje, ale profesor był w tej sprawie dyskretny. Dopiero po powstaniu „Solidarności” zdecydował się na omówienie jej fragmentu (poświęconego radom zakładowym) na seminarium prawa pracy, które prowadził w Uniwersytecie Łódzkim.

Opublikowanie książki po wielu latach od jej powstania i od śmierci Autora jest zgodne z Jego intencją, którą wyraził w zakończeniu opracowania: „Nie byłoby [...] uzasadnione przypisywanie pracom koncepcyjnym Departamentu trwalszego znaczenia od tego, jakie było zdeterminowane ich charakterem oraz warunkami, w jakich były prowadzone. Umiejscowione w tych warunkach i czasie ukazują one jednak szersze horyzonty myśli poszukującej dróg przebudowy społecznej oraz pozostają w tym zakresie dokumentem, który nie powinien ulec zapomnieniu".

Uczniowie profesora wypełniają tę wolę w setną rocznicę Jego urodzin. Ta książka dopełnia dorobek naukowy W. Szuberta i stanowi dowód Jego zaanga- 
żowania w konspiracyjną działalność Polskiego Państwa Podziemnego w czasie II wojny światowej. Jest ona także świadectwem niezłomności Narodu Polskiego, który w tym tragicznym okresie swoich dziejów miał odwagę planować społeczny ustrój państwa po odzyskaniu niepodległości.

Przygotowując książkę do druku, zachowano tekst napisany przez Autora w stanie niezmienionym. Dokonane zostały jedynie niezbędne korekty redakcyjne: usunięto błędy literowe, rozwinięto nazwy własne zapisane skrótowo, poprawiono pomyłki w pisowni nazwisk itp. Opuszczono też kilka przypisów, które nie odsyłały do konkretnego dzieła lub fragmentu tekstu, co jednak nie miało wpływu na merytoryczny sens tekstu autorskiego.

Michat Seweryński 


\section{Nota biograficzna}

Wacław Szubert urodził się 19 IX 1912 r. we Włocławku. W 1934 r. uzyskał tytuł magistra prawa na Uniwersytecie Warszawskim, a dwa lata później obronił na Wydziale Prawa UW pracę doktorską pt. Dzieje ubezpieczenia na wypadek bezrobocia w Anglii. Bezpośrednio po uzyskaniu stopnia doktora podjął pracę w Instytucie Spraw Społecznych w Warszawie, gdzie jako asystent zajmował się ubezpieczeniami społecznymi do końca listopada $1939 \mathrm{r}$.

W czasie wojny W. Szubert początkowo (od grudnia 1939 r.) pracował w działającym za zgodą władz okupacyjnych Stołecznym Komitecie Samopomocy Społecznej (podporządkowanym później Radzie Głównej Opiekuńczej), jako sekretarz sekcji do spraw pracy. W listopadzie 1941 r., w związku z próbą aresztowania przez gestapo, zrezygnował z tej pracy i poświęcił się całkowicie działalności konspiracyjnej. Działalność tę rozpoczął jednak już wcześniej: od lutego 1941 r. pracował w komórce, z której powstał Wydział Informacji BIP KG AK. Zorganizował tu i prowadził przez ponad trzy lata referat społeczny, który nie tylko gromadził informacje o warunkach życia i pracy ludności oraz o polityce eksterminacyjnej okupanta, lecz także współorganizował akcję opieki czynnej (pomoc dla więźniów i rodzin rozstrzelanych).

Na początku 1943 r. W. Szubert otrzymał propozycję przejścia do Departamentu Pracy i Opieki Społecznej Delegatury Rządu, którą początkowo - nie chcąc opuszczać AK - odrzucił. Ostatecznie jednak w lipcu 1943 r., na wniosek Delegata Rządu na Kraj - Jana Stanisława Jankowskiego, został odkomenderowany na stanowisko zastępcy dyrektora Departamentu Pracy. Zmiana przydziału miała raczej charakter organizacyjny: z jednej strony, podobnie jak w BIP KG AK, W. Szubert zajmował się tutaj opieką czynną nad ludnością polską, z drugiej strony już wcześniej (od 1941 r.) brał udział w pracach koncepcyjnych Departamentu, kierowanego wówczas właśnie przez J.S. Jankowskiego.

Równolegle W. Szubert uczestniczył w tajnym nauczaniu: od września 1942 r. prowadził kurs wiedzy społecznej, a od października 1943 r. do 31 VII 1944 r. pracował jako wykładowca na Wydziale Prawno-Ekonomicznym Wolnej Wszechnicy Polskiej w Warszawie. 
W czasie powstania warszawskiego W. Szubert łączył działalność w strukturach cywilnych i wojskowych. Przede wszystkim nadal pozostawał zastępcą dyrektora Departamentu Pracy, którego formalne rozwiązanie nastąpiło dopiero w lipcu 1945 r., jednocześnie jednak aż do upadku powstania, jako współpracownik Wydziału Informacji BIP KG AK, wchodził w skład personelu radiostacji „Anna” zainstalowanej przy ul. Marszałkowskiej. Po kapitulacji miasta i zabezpieczeniu dokumentów Departamentu opuścił Warszawę wraz z ludnością cywilną 6 X 1944 r.

W okresie powojennym W. Szubert nierozerwalnie związał się z Uniwersytetem Łódzkim. 1 IV 1945 r. został zatrudniony jako zastępca profesora UŁ, z misją utworzenia Katedry Polityki Społecznej i Ustawodawstwa Społecznego (przemianowanej w 1950 r. na Katedrę Prawa Pracy i Ubezpieczeń Społecznych), którą kierował nieustannie do $1982 \mathrm{r}$. W tym czasie pełnił również funkcje prodziekana (w latach 1950-1953) i dziekana Wydziału Prawa UŁ (w latach 1953-1955 i 1965-1969), a także dyrektora Instytutu Pracy i Spraw Socjalnych w Warszawie (1973-1978). Równocześnie prowadził szeroką działalność naukową, badając problemy z zakresu prawa pracy, ubezpieczeń społecznych i polityki społecznej. Jej zwieńczeniem było nadanie czterech tytułów doktora honoris causa uniwersytetów: Wrocławskiego (1981), Bordeaux I (1983), Jagiellońskiego (1987) i Łódzkiego (1988).

W. Szubert był członkiem m.in. Polskiego Towarzystwa Ekonomicznego (1947-1994), Łódzkiego Towarzystwa Naukowego (1948-1994), Société de Législation Comparé w Paryżu (1969), członkiem rzeczywistym PAN (1976-1994), członkiem-korespondentem Międzynarodowej Akademii Prawa Porównawczego (1979-1994), członkiem zwyczajnym Towarzystwa Naukowego Warszawskiego (1984-1994). W latach 1958-1994 był członkiem zarządu i przewodniczącym polskiej sekcji Société Internationale de Droit du Travail et de la Sécurité Sociale, a od roku 1985 - honorowym prezesem tego stowarzyszenia. Był członkiem rad naukowych Centralnego Instytutu Ochrony Pracy (1958-1980) i Instytutu Nauk Prawnych PAN (1958-1994). W latach 1978-1984 oraz 1990-1992 był przewodniczącym Komitetu Nauk Prawnych PAN; niemal jednocześnie (1976-1981) był także wiceprzewodniczącym Komitetu Problemów Pracy i Polityki Społecznej PAN. W listopadzie 1981 r. został wybrany wiceprzewodniczącym powoływanej wówczas Społecznej Rady Legislacyjnej przy Centrum Obywatelskich Inicjatyw Ustawodawczych „Solidarności”.

Wacław Szubert zmarł 16 I 1994 r. w Warszawie. 


\section{Wstęp}

O powstaniu niniejszej pracy rozstrzygnęło przeświadczenie, że wiedza o latach wojny i okupacji w naszym kraju, udokumentowana na bogatym piśmiennictwie, wymaga pewnego uzupełnienia. Liczne publikacje poświęcone tamtej epoce dają przede wszystkim obraz toczonej wówczas walki i martylologii, charakteryzują struktury organizacyjne i działalność państwa podziemnego, a także sylwetki ludzi, którzy odgrywali wtedy kluczową rolę. Dają obraz różnych formacji politycznych, ich ścierających się wpływów i programów oddziaływających na kształtowanie się ówczesnej rzeczywistości i na wyłaniający się z niej kształt powojennej Polski.

Brak jest natomiast pogłębionej refleksji nad treścią prowadzonych wówczas prac koncepcyjnych, które nie ograniczały się do wskazania ogólnych idei programowych, lecz przynosiły projekty reform obejmujących różne dziedziny życia społecznego w dłuższej perspektywie czasu poza lata powojenne.

Prace tego rodzaju prowadzone były z niejednakowym natężeniem w różnych komórkach organizacyjnych Delegatury Rządu RP na Kraj, a w szczególności $\mathrm{w}$ jej departamentach, zobowiązanych nie tylko do podejmowania zadań o bezpośrednim praktycznym znaczeniu (np. organizowanie tajnego nauczania czy też opieki nad osobami represjonowanymi przez okupanta), lecz także do przygotowywania rozwiązań prawno-organizacyjnych, służących przejęciu władzy i określeniu zasad polityki Rządu w przyszłym państwie polskim. Całość tych prac, składających się na obfity materiał zawarty w różnych opracowaniach programowych, tezach i projektach aktów prawnych, a także wewnętrznych opiniach obrazujących fazy ich powstawania, zasługuje na uwagę i na poddanie go wnikliwej analizie.

Prace, o których mowa, stanowią ważny rozdział kształtowania się polskiej niezależnej myśli społecznej w warunkach, które utrudniały wprawdzie niepomiernie prowadzenie tego rodzaju studiów, lecz równocześnie mobilizowały do nadania im maksymalnej intensywności.

Byłoby błędem ocenianie tych przedsięwzięć jako mających tylko znaczenie efemerydalne ze względu na to, że toczyły się w stosunkowo krótkim okresie 
lat wojny i nie mogły być wykorzystane bezpośrednio po jej zakończeniu, gdy losy kraju zostały zdominowane przez obce wpływy. Prace te wymagają bowiem wpisania w dłuższy ciąg rozwojowy polskiej myśli społecznej jako jego część integralna.

Przede wszystkim były one inspirowane przez realia okresu międzywojennego oraz idee wybitnych przedstawicieli myśli społecznej tamtych lat, którzy poszukiwali dróg przezwyciężenia społeczno-gospodarczej słabości kraju i pchnięcia jego rozwoju na nowe tory. Nie bez wpływu na te prace pozostawały również idee przebudowy społeczno-gospodarczej, zdobywającej sobie w czasie wojny prawo obywatelstwa na Zachodzie.

W okresie powojennym prace, o których mowa, nie mogły wywrzeć wpływu na kształtowanie się ówczesnego porządku społeczno-gospodarczego, który był budowany na zupełnie odmiennych zasadach. Można natomiast postawić sobie pytanie, $w$ jakiej mierze sprawdziły się niektóre zawarte $\mathrm{w}$ tych pracach przewidywania dotyczące procesów i zjawisk niezależnych od ingerencji władz, wobec których musiały one w każdych okolicznościach zająć stanowisko. Wydaje się, że sporo takich trafnych przewidywań dotyczyło zwłaszcza lat bezpośrednio powojennych. Natomiast z chwilą dokonania się zasadniczego przełomu i odrzucenia zasad, na których opierał się system tzw. realnego socjalizmu, powstały możliwości szerokiego czerpania $\mathrm{z}$ dorobku polskiej niezależnej myśli, w tym także $\mathrm{z}$ opracowań powstałych $\mathrm{w}$ latach wojny, w takim zakresie, $\mathrm{w}$ jakim nie straciły one aktualności.

Długi, bo prawie 50-letni okres, jaki upłynął od ich powstania, zmniejszył niewątpliwie ich bezpośrednią przydatność. Wydaje się jednak, że współczesna polityka pracy staje wobec wielu problemów, jakie nasuwały się autorom projektów opracowywanych w latach wojny, przynajmniej w kwestii podstawowych rozwiązań określających zasady ustroju pracy i polityki społecznej. Nie oznacza to bezpośredniej przydatności ówczesnych projektów do praktycznego zastosowania, jednak zapoznanie się z nimi może być pomocne w wypracowywaniu optymalnych rozwiązań odpowiadających obecnym potrzebom. Dotyczy to przy tym nie tylko ogólnych założeń i myśli przewodnich, lecz również szczegółowych koncepcji, które mogą okazać się zaskakująco trafne i przydatne we współczesnym ustawodawstwie.

Uwzględnienie dorobku polskiej myśli z lat okupacji skłania do spojrzenia na jego ciąg rozwojowy z ogólniejszego punktu widzenia. Atrakcyjność różnych idei programowych, jakie znajdowały w nim wyraz, była w znacznej mierze uwarunkowana charakterem ówczesnych potrzeb i stanowiła pewnego rodzaju reakcję na wady systemu, od którego chciano się oderwać. W czasie wojny idea gospodarki planowej zdawała się wskazywać jedyną drogę dla zmobilizowania sił służących rozwojowi gospodarczemu kraju. Zapowiadała przezwyciężenie anarchii wolnego rynku, w tym zwłaszcza rynku pracy, na którym praca ludzka była degradowana do roli towaru. 
We współczesnych przemianach wolny rynek jawi się natomiast jako jedyne panaceum na zwyrodnienie planowej gospodarki, która w istniejącej u nas postaci ugruntowała wszechwładzę aparatu partyjno-państwowego, paraliżując wszelkie możliwości rozwijania inicjatywy indywidualnej i grupowej oraz niezależnego organizowania się sił społecznych.

W każdej z tych faz kształtowania się myśli społecznej nieuniknione były przejaskrawienia i uproszczenia, polegające na oczekiwaniu uzdrawiających skutków od zastosowania nowych koncepcji ustrojowych. Współcześnie przejawem tej postawy jest występująca w pewnych kołach przesadna wiara w pozytywną rolę „niewidzialnej ręki” wolnego rynku, która miałaby samoczynnie wyrównać występujące poprzednio nieprawidłowości i dysproporcje. W koncepcjach z okresu wojny nie ustrzeżono się natomiast wyciągania daleko idących wniosków ze słusznej krytyki stosunków panujących przed wojną na rynku pracy, kwestionując samą ich prawną podstawę, a nie tylko nadużywanie jej na niekorzyść pracowników.

W jednym i drugim przypadku dochodziła do głosu wiara w możność oparcia porządku społecznego na jednej, konsekwentnie zastosowanej zasadzie, wbrew doświadczeniu historycznemu, które każe kwalifikować takie zamierzenia jako utopijne i niemożliwe do trwalszego zastosowania, choćby przejściowo usiłowano je w takiej lub innej formie narzucić.

Przede wszystkim jednak w retrospektywnym spojrzeniu na różne koncepcje przebudowy społecznej, konieczne jest uściślenie pojęć określających jej podstawy. Dotyczy to szczególnie pojęcia gospodarki planowej, któremu bywa nadawana różna treść. W koncepcjach $\mathrm{z}$ lat wojny oznaczała ona kierowniczą rolę państwa $\mathrm{w}$ gospodarce, przy częściowym jedynie uspołecznieniu środków produkcji oraz umocnieniu roli organów samorządu społeczno-gospodarczego, mającego zapobiegać przerostom biurokracji państwowej. Była to wizja zasadniczo odmienna od modelu gospodarki planowej, wprowadzonego po wojnie, który sprowadzał się do nacjonalizacji wszystkich środków produkcji poza drobnym rolnictwem i rzemiosłem oraz do monopolistycznej pozycji państwa jako przedsiębiorcy i pracodawcy.

Wszystkie powyższe okoliczności trzeba mieć na uwadze, aby trafnie odczytać i ocenić charakter programu społeczno-gospodarczego, jaki został opracowany przez organy Polskiego Państwa Podziemnego w latach II wojny światowej. Studium tego programu powinno bowiem nie tylko dać wierny obraz jego treści, lecz również określić jego miejsce wśród różnych koncepcji społeczno-ustrojowych danej epoki oraz stanowić przyczynek do uwydatnienia czynników wpływających na treść zawartych w nich postulatów oraz na sposób ich formułowania.

Koncepcje programowe Delegatury Rządu w okresie okupacji stanowiły - jak wspomniano - wynik prac prowadzonych przez różne jej komórki organizacyjne (departamenty), a syntetyczny ich obraz znalazł odbicie w deklaracji Rady Jedności Narodowej opublikowanej w marcu 1944 r. Opracowanie niniejsze 
nie stawia sobie za cel pełnego przedstawienia tych koncepcji. Ogranicza się ono do tej ich części, która dotyczyła czynnika pracy i związanych z nim zagadnień społeczno-gospodarczych. Zadecydowało o tym przeświadczenie, że te właśnie sprawy miały rozstrzygające znaczenie w określaniu charakteru przyszłego państwa polskiego, jego podstaw ustrojowych i perspektyw rozwojowych. Na tych też sprawach skupiało się w czasie wojny szczególne zainteresowanie, a poświęcone im prace programowe miały wyjątkową intensywność i wyraźny kierunek, zmierzający do budowy „ustroju opartego na pracy” oraz do nadania ludziom pracy „prawa współobywatelstwa społeczności gospodarczej”. Skoncentrowanie uwagi na tej problematyce sprzyja również jej pogłębieniu. Jest ono też możliwe dzięki zachowaniu się materiałów $\mathrm{z}$ tego zakresu w archiwach oraz w zbiorach prywatnych.

Wizja przyszłego obrazu polityki społecznej i ustroju w powojennej Polsce kształtowała się przede wszystkim w opracowaniach programowych jednej komórki Delegatury Rządu, a mianowicie w Departamencie Pracy i Opieki Społecznej, który powstał w 1941 r. O randze tego Departamentu rozstrzygnął nie tylko sam charakter jego zadań, a w pewnej mierze także intensywność prowadzonych przezeń prac, lecz również fakt, że od początku na jego czele stanął wybitny znawca zagadnień społecznych pracy i polityk Jan Stanisław Jankowski, który nie przestał interesować się żywo jego pracami, gdy został powołany w 1943 r. na stanowisko Delegata Rządu na Kraj, a następnie wicepremiera RP. Kierownictwo Departamentu przypadło natomiast wówczas wybitnemu prawnikowi, zasłużonemu sędziemu sądów pracy, Stefanowi Matei, mającemu szczególny dar inspirowania prac zespołowych i promowania nowatorskich idei. O pozycji S. Matei świadczy fakt, że nie będąc członkiem żadnej partii, mógł być mianowany dyrektorem tak ważnego departamentu, pomimo obowiązującego wówczas klucza partyjnego przy obsadzie tego typu stanowisk.

Zadecydowało o tym zaufanie do S. Matei jako człowieka prawego i fachowego oraz głęboko zaangażowanego na rzecz programu głębokich reform społecznych, służących umocnieniu pozycji człowieka pracy i ugruntowaniu zasad sprawiedliwości społecznej. Orientacja ta zbliżała S. Mateję do Polskiej Partii Socjalistycznej (WRN), a także do Partii Pracy, z których każda uważała go po trochu za swojego człowieka, a niekiedy nawet deklarowała oficjalnie jego przynależność, mimo odmiennego stanu rzeczy.

Wskazana wyżej orientacja nie ograniczała jednak jego horyzontów myślowych ani inwencji twórczej w poszukiwaniu rozwiązań służących urzeczywistnianiu wyznawanych przez niego idei bez względu na etykietki, jakimi opatrywano te koncepcje. Na gruncie wyznawanych przez siebie zasad był S. Mateja człowiekiem niezależnie myślącym, otwartym na sugestie przydatne w ich urzeczywistnianiu, chodzącym własnymi drogami w obmyślaniu projektów reform. Cała jego postawa była zaprzeczeniem doktrynerstwa, a także wolna od poczucia ważności związanego z przynależnością do kierowniczego gremium Delegatury Rządu. 
W kierowanym przez siebie Departamencie Pracy i Opieki Społecznej pragnął widzieć ludzi zaangażowanych społecznie i fachowych. Był dla nich niezawodnym przewodnikiem, a także starszym kolegą i przyjacielem w kontaktach osobistych, wykraczających poza stosunki pomiędzy szefem a podwładnymi.

Wszystko to rozstrzygnęło o szczególnej atmosferze, jaka towarzyszyła pracom tego ,zespołu ideowo-fachowego”, który stanowili pracownicy Departamentu. Praca konspiracyjna sprzyjała w wielu przypadkach powstawaniu bliskich koleżeńskich i przyjacielskich stosunków pomiędzy ludźmi współpracującymi na co dzień, zwłaszcza w formacjach walki zbrojnej. Wolno jednak stwierdzić, że Departament Pracy i Opieki Społecznej Delegatury Rządu stanowił szczególny przykład wytworzenia się takiego układu w administracji cywilnej podziemnego państwa.

Okoliczność ta skłania do poprzedzenia charakterystyki koncepcji programowych, składających się na główną treść niniejszej pracy, zobrazowaniem środowiska, w którym koncepcje te powstały. Z tą myślą poświęcamy pierwszą część niniejszej publikacji samemu Departamentowi Pracy i Opieki Społecznej, starając się w niej określić pozycję Departamentu w Delegaturze Rządu, jego skład osobowy, organizację wewnętrzną i metody pracy oraz zakres działalności wykraczającej poza opracowywanie koncepcji przyszłościowych ${ }^{1}$.

W drugiej, nierównie obszerniejszej, części podejmujemy natomiast charakterystykę opracowań przedstawiających wizję polityki społecznej i pozycji czynnika pracy w przyszłej Polsce: jej założeń ogólnych, a następnie najważniejszych dziedzin przez nią objętych, którymi były polityka zatrudnienia i płac, ustrój pracy, prawo pracy, ubezpieczenia społeczne oraz niektóre inne zakresy polityki społecznej, w szczególności służba zdrowia i opieka społeczna.

W każdym z tych zakresów ambicją autora jest wierne przedstawienie koncepcji Departamentu oraz ich przesłanek i uwarunkowań, a także poddanie ich rzeczowej analizie uwydatniającej zarówno ich wartości, jak i to, co może być w nich ocenianie krytycznie czy to ze względu na obranie wątpliwego kierunku rozwiązań, czy też niedostateczne ich rozwinięcie. Tego ostatniego zwłaszcza zarzutu trudno będzie uniknąć, ponieważ prace programowe Departamentu zostały w różnych dziedzinach w nierównym stopniu zaawansowane. Stąd też obok myśli wyraźnie skrystalizowanych i ubranych w wykończoną szatę legislacyjną występują niekiedy w dorobku Departamentu idee wskazujące tylko orientacyjnie kierunek pożądanych rozwiązań. Te pierwsze dotyczą jednak na tyle ważnych zakresów polityki społecznej i ustroju pracy, że pozwalają na odczytanie podstawowych treści programu.

Zakończenie zawiera podsumowanie całości rozważań oraz ogólniejszą refleksję nad koncepcjami z lat wojny ze stanowiska późniejszych doświadczeń oraz nad ich pozycją w dorobku polskiej myśli społecznej, dotyczącym społeczno-prawnych i gospodarczych problemów pracy.

${ }^{1}$ Te informacje s zawarte w aneksie II. 
Opracowanie opiera się, jak już wspomniano, na bogatym materiale źródłowym zawartym $\mathrm{w}$ archiwach $\mathrm{i} \mathrm{w}$ zbiorach prywatnych, a także na publikacjach z lat okupacji i na literaturze przedmiotu mającej związek z jego treścią. O jeszcze jednym źródle należałoby osobno wspomnieć. Jest nim pamięć osobista autora, który w ciągu dwóch lat (1943-1945) był zastępcą dyrektora Departamentu Pracy i Opieki Społecznej Delegatury Rządu, a poprzednio już (od 1941 r.) uczestniczył $\mathrm{w}$ jego pracach. Wspomnieniom osobistym $\mathrm{z}$ tego okresu autor poświęcił odrębną publikację. W tym natomiast opracowaniu pragnie ograniczyć się do relacji o znanych mu faktach i dokumentach. 


\section{Część pierwsza}

\section{Ogólne założenia programowe}

Prace programowe inspirowane „myślą o planowaniu nowego świata” zostały podjęte w latach „klęski i rozgromu” ", których następstwa stale się pogłębiały, a ostateczny obraz był trudny do przewidzenia. Pomnażała się dramatycznie hekatomba krwawych ofiar, powiększało się wyniszczenie biologiczne szerokich warstw społeczeństwa, wzrastała ustawicznie liczba osób wyrywanych ze swojego środowiska przez deportacje, wysiedlenia, zamykanie w obozach koncentracyjnych. Towarzyszył temu ogrom strat materialnych trudnych do oszacowania, prowadzących do unicestwienia znacznej części polskiego dorobku gospodarczego i kulturalnego.

Nie podważało to wiary $\mathrm{w}$ ostateczne zwycięstwo $\mathrm{i} \mathrm{w}$ powstanie na nowo niepodległego państwa polskiego, którego podstawy prawne i społeczno-gospodarcze starano się bliżej określić, wyciągając wnioski z bolesnych doświadczeń niedawnej przeszłości. Pracom programowym, zmierzającym do tego celu, brakowało wielu podstawowych punktów orientacyjnych. Nie wiadomo było, jak będzie się ostatecznie przedstawiała po wojnie substancja i kondycja społeczeństwa polskiego, a także jego struktura i rozmieszczenie przestrzenne. Jak ukształtuje się ostatecznie bilans strat, pasywa i aktywa, jakie wartości uda się ocalić bądź uzyskać kosztem odszkodowań. Brakowało również orientacji co do tego, jak ukształtują się granice przyszłego państwa polskiego, jakkolwiek powszechnie zakładano objęcie nimi nowych ziem na zachodzie i północy (w tym ostatnim kierunku łącznie z Królewcem²).

Należało liczyć się w każdym razie z pewnym okresem destabilizacji, związanej z masowymi ruchami ludności powracającej do kraju i poszukującej w jego nowych granicach miejsc osiedlenia. Wszystko to stanowiło poważną trudność w określaniu podstaw nowego społeczno-politycznego i gospodarczego ładu,

\footnotetext{
${ }^{1}$ S. Ossowski, Ku nowym formom życia spotecznego, Warszawa 1947, s. 13 (broszura wydana poprzednio konspiracyjnie w dwóch częściach w Warszawie, 1943).

${ }^{2}$ Wymownym tego świadectwem było powołanie w 1942 r. Biura Ziem Nowych, powiązanego organizacyjnie z Departamentem Spraw Wewnętrznych Delegatury Rządu. Por. S. Korboński, Polskie Państwo Podziemne, Bydgoszcz, b.r., s. 53.
} 
pomyślanego na dalszą przyszłość, a równocześnie mogącego stawić czoło trudnościom okresu przejściowego.

Naturalnym punktem odniesienia były realia okresu międzywojennego, do których siłą rzeczy należało nawiązać, ale od których równocześnie chciano się oderwać, aby oprzeć budowę nowego państwa polskiego na mocniejszych podstawach. Stosunek do tamtego dwudziestolecia kształtował się bowiem ambiwalentnie. $Z$ jednej strony doprowadziło ono do zrośnięcia się trzech byłych dzielnic zaborczych $\mathrm{w}$ jednolity organizm państwowy oraz przyniosło cenne osiągnięcia, do których należało przede wszystkim zbudowanie portu w Gdyni, a w ostatnich latach przed wojną wydatne wzmożenie ruchu inwestycyjnego, zwłaszcza w tzw. Centralnym Okręgu Przemysłowym. Przyniosło też przede wszystkim odrodzenie niepodległej Polski, której dalsze trwanie symbolizowało - wbrew okupacyjnym realiom - istnienie polskiego Rządu emigracyjnego w Londynie tudzież jego delegatury w kraju oraz podlegających im sił zbrojnych i struktur administracyjnych. Utrzymanie tej ciągłości oraz przedłużenie jej na okres powojenny uznawane było ze zrozumiałych względów za podstawową wartość.

Z drugiej strony nie można było zamykać oczu na słabości Polski dwudziestolecia międzywojennego, które tłumaczyły się w znacznej mierze warunkami, w jakich nastąpił jej powrót do niepodległego bytu, ale których nie zdołano w ciągu tych lat znacząco zmniejszyć, nie mówiąc już o ich wyrównaniu. Po I wojnie światowej Polska odrodziła się jako spustoszony „kraj nędzarzy”3 i zmuszona była jeszcze przez parę lat walczyć o ostateczny kształt swych granic, a także przeciwko wrogiej polityce gospodarczej zachodniego sąsiada (wojna celna). Objęła terytorium niestanowiące jednolitego organizmu gospodarczego ${ }^{4}$ oraz odziedziczyła strukturę społeczno-gospodarczą, nacechowaną słabym uprzemysłowieniem i dominacją prymitywnego rolnictwa. Musiała stawić czoła dwom kryzysom: lat 1923-1926 oraz przede wszystkim lat 1929-1934, który spowodował ogromny regres gospodarczy i zubożenie szerokich kręgów ludności. Borykała się stale z dysproporcjami: między zasobem rozporządzalnych środków a rozmiarem potrzeb, między niewspółmiernościami w rozwoju poszczególnych dzielnic, między potencjałem własnym a reprezentowanym przez potężnych sąsiadów ${ }^{5}$. Błędem własnym było natomiast uporczywe trzymanie się liberalnej polityki walutowej i obrona stałego kursu złotego, co wpływało hamująco na rozwój gospodarczy kraju. Dopiero w 1936 r. nastąpiła w tym względzie zmiana, która przyniosła znaczący, acz spóźniony, wzrost inwestycji finansowanych przez państwo i ożywienie gospodarcze ${ }^{6}$.

${ }^{3}$ E. Kwiatkowski, Dysproporcje, Warszawa 1989, s. 180.

${ }^{4}$ B. Zientara, A. Mączak, I. Ihnatowicz, Z. Landau, Dzieje gospodarcze Polski do 1939 r, Warszawa 1965, s. 469 (cytowane dalej jako Dzieje gospodarcze).

${ }^{5}$ E. Kwiatkowski, op. cit., s. 291, 310, 326.

${ }^{6}$ Dzieje gospodarcze, s. 510-511. 
W ostatecznym wyniku globalna produkcja przemysłu polskiego w $1938 \mathrm{r}$. zaledwie zrównała się z jej poziomem z 1913 r., a w przeliczeniu na głowę mieszkańca pozostawała za nim wyraźnie w tyle. Rozwój przemysłu nie nadążał zatem za wzrostem ludności ${ }^{7}$. Nie nastąpiła też znacząca zmiana struktury rolnictwa ani rozwój produkcji rolnej, a poziom życia ludności chłopskiej spadł nawet poniżej przedwojennego ${ }^{8}$. Ogromna część ludności rolniczej tkwiła w systemie gospodarki naturalnej.

Aparat wytwórczy kraju nie mógł w tym stanie rzeczy zapewnić znacznej części ludności racjonalnego zatrudnienia. Liczebność roczników młodzieży wkraczającej w późnych latach trzydziestych w wiek produkcyjny przekraczała corocznie prawie o 300000 liczbę dostępnych dla niej miejsc pracy9. Liczba osób niewykorzystanych produkcyjnie (a więc tzw. zbędnych) w gospodarstwach rolnych wynosiła, według najbardziej optymistycznych obliczeń IGS, prawie $2500000^{10}$. Rozwiązanie tych problemów narzucało się jako szczególnie ważne we wszelkich planach perspektywicznych, opracowywanych w czasie okupacji.

Niepokój musiała jednak również budzić sytuacja ludności pozostającej w zatrudnieniu. Była ona wprawdzie objęta ustawodawstwem ochronnym, którego treść miała wyraz społecznie postępowy (i z tego zresztą powodu była stale przedmiotem krytyki ze strony tzw. sfer gospodarczych). W praktyce ustawodawstwo to było jednak notorycznie łamane, zwłaszcza w latach kryzysowych oraz w mniejszych zakładach pracy, czemu inspekcja pracy nie była w stanie skutecznie się przeciwstawić $^{11}$. Dotyczyło to zarówno czasu pracy i urlopów pracowniczych, jak również ochrony pracy kobiet i młodocianych oraz bezpieczeństwa i higieny pracy.

Niedostateczna ochrona wynagrodzenia za pracę wynikała natomiast z wąskiego zakresu jego regulacji poprzez układy zbiorowe pracy oraz ze słabości związków zawodowych, które cechowało rozbicie organizacyjne i relatywnie mała liczba członków płacących składki. Inspekcja pracy stwierdzała częste zaleganie przedsiębiorstw $\mathrm{z}$ wypłatą zarobków ${ }^{12}$, a wiadomo było, że pracownicy rzadko uciekali się do ochrony sądowej, nie chcąc narażać się pracodawcy w obawie o utratę zatrudnienia. Nie istniało powszechne przedstawicielstwo pracownicze w zakładach pracy oraz nie rozwinął się samorząd pracowniczy na szczeblu ogólnopaństwowym w postaci izb pracy, przewidzianych w konstytucji z $1921 \mathrm{r}$., ale nie wprowadzonych w życie, co upośledzało pozycję czynnika pracy w państwie w porównaniu ze sferami przemysłowymi ${ }^{13}$.

${ }^{7}$ Ibidem, s. 496, 504.

${ }^{8}$ Ibidem, s. 487-488.

${ }^{9}$ Młodzież sięga po pracę. Instytut Sprawa Społecznych, Warszawa 1938, s. 85.

${ }^{10}$ Bezrobocie wśród chłopów. Instytut Gospodarstwa Społecznego, Warszawa 1939, s. 145.

${ }^{11}$ M. Klott, Ustawodawstwo społeczne a rzeczywistośćc, „Przegląd Ekonomiczny” (Lwów) 1937, t. XVIII, nr. 87-90, s. 49-75 i n.

${ }^{12}$ Ibidem, s. 54.

${ }^{13}$ W. Landau, Izby Pracy, Warszawa 1932, s. 7 i n. 
W tym stanie rzeczy rynek pracy kształtował się, pomimo obowiązywania przepisów i struktur ochronnych, pod przemożnym wpływem pracodawców, co sprawiało, że sama praca nabierała cech towaru będącego przedmiotem wymiany, na warunkach niepodlegających praktycznie skutecznej kontroli.

Sprawę pogarszało daleko idące zróżnicowanie sytuacji prawnej pracowników, które stwarzało wśród nich liczne linie podziału, rażące poczucie niesprawiedliwości społecznej. Należał do nich przede wszystkim podział pracowników na fizycznych (robotników) i umysłowych, który ukształtował się na gruncie tradycji i zwyczajów, a także fragmentarycznych regulacji z czasów zaborczych, stwarzając krzywdzące różnice uprawnień, którym trudno byłoby przyznać rzeczowe uzasadnienie ${ }^{14}$. Dotyczyło to nie tylko uprawnień w dziedzinie samego prawa pracy, lecz również ubezpieczeń społecznych. Szczególnie upośledzoną kategorię stanowili robotnicy rolni, w stosunku do których obowiązywał przez cały okres dwudziestolecia odrębny reżim prawny ${ }^{15}$.

System ubezpieczeń społecznych był nie tylko nacechowany wspomnianymi wyżej dysproporcjami, lecz ponadto nierównomiernością w pokrywaniu potrzeb związanych z różnymi rodzajami ryzyk losowych. Kryzys lat trzydziestych ograniczył poważnie efektywność i rozmiary świadczeń udzielanych na wypadek choroby. Świadczenia na starość dla robotników zaczęto wypłacać w skromnej wysokości dopiero w 1938 r. Hamulcem rozwoju ubezpieczeń były konflikty wokół związanych z nimi obciążeń składkowych. Sfery gospodarcze domagały się stale ich redukcji oraz występowały z postulatami ograniczenia świadczeń do poziomu gwarantującego jedynie minimalne zaspokojenie potrzeb. Poddawały też zasadniczej krytyce nadmierny, ich zdaniem, rozwój polityki społecznej, uznając go za niewspółmierny do możliwości gospodarczych kraju ${ }^{16}$.

Stwierdzenia powyższe nie przekreślały mimo wszystko osiągnięć dwudziestolecia w zakresie gospodarczym i socjalnym, a także w dziedzinie organizacji i funkcjonowania instytucji publicznych. W całości jednak ówczesna Polska borykała się z dramatycznymi problemami, których przezwyciężenie nie leżało w zakresie jej możliwości. Obraz ten tkwił mocno w świadomości ludzi podejmujących w latach wojny trud opracowania programu na przyszłe lata, po przywróceniu niepodległości. Było bowiem rzeczą jasną, że w programie tym należy dążyć nie tylko do wyrównania strat ostatniej wojny i sprawnego uchwycenia na nowo steru rządów, lecz również, czy może nawet przede wszystkim, do usunięcia źródeł dawnych słabości i podźwignięcia gospodarki i życia społecznego kraju na wyższy poziom, gwarantujący mu bezpieczny byt. Program taki musiał znaleźć

${ }^{14}$ M. Święcicki, Instytucje polskiego prawa pracy w latach 1918-1939, Warszawa 1960, s. 69 i 138 .

${ }^{15}$ Ibidem, s. 46.

${ }^{16}$ Program gospodarczy Centralnego Związu Przemystu Polskiego, Warszawa 1933, s. $140 \mathrm{in}$. 
odpowiedź na wskazane wyżej problemy i mieć w związku z tym kompleksowy, szeroko zakrojony charakter.

Kluczowe było przede wszystkim wypowiedzenie się w kwestii zasadniczego charakteru polityki społeczno-gospodarczej państwa. Stanowisko w tej sprawie ulegało stopniowej krystalizacji. Wbrew kierunkowi polityki prowadzonej przez państwo polskie do ostatnich lat międzywojennych oraz wbrew wypowiedziom przedstawicieli sfer przemysłowych, gloryfikujących wolność gospodarczą i automatyzm procesów dostosowawczych w sferze ekonomiki ${ }^{17}$, a także politykę deflacyjną ${ }^{18}$ i pozytywną rolę karteli ${ }^{19}$, rozpowszechniało się coraz bardziej przekonanie o konieczności zdecydowanego wzmocnienia wpływu państwa na kierowanie procesami gospodarczymi.

Idee te miały w naszym systemie gospodarczym odległy rodowód. Kiełkowały już na przełomie XIX i XX w. ${ }^{20}$, a w okresie międzywojennym przyznawało się do nich wielu ekonomistów pozostających poza kręgiem myśli marksistowskiej. Należał do nich Eugeniusz Kwiatkowski, który podkreślał znaczenie „bezpośredniej działalności ekonomicznej państwa" (odróżnianej przez niego zdecydowanie od etatyzmu) oraz „planowości w rozwoju ekonomicznym”"21, a także Stanisław Grabski, wypowiadający się za „narodową gospodarką planową”, której istotę miało stanowić „kierowanie rozwojem gospodarczym”22, zwłaszcza przypływem kapitałów i kredytów do różnych gałęzi produkcji, co miało przyczynić się do podniesienia sił wytwórczych kraju, a tym samym do likwidacji przeludnienia wsi i zapewniania pracy całemu przyrostowi ludności ${ }^{23}$.

Znacznie radykalniej wypowiadał się w tych sprawach (w pismach z okresu międzywojennego) Oskar Lange, który wbrew stanowisku cytowanych wyżej ekonomistów postulował wywłaszczenie banków i wszystkich większych przedsiębiorstw (zatrudniających ponad 20 pracowników). Określał on jednak tę operację jako uspołecznienie (a nie upaństwowienie) środków produkcji oraz przestrzegał przed „zbiurokratyzowaniem życia gospodarczego" i domagał się oddzielenia „zarządu gospodarczego od władzy politycznej” przy zachowaniu autonomii jednostek produkcyjnych tudzież samorządu mas pracujących ${ }^{24}$.

${ }^{17}$ C. Klarner, Zadania i wytyczne państwowej polityki gospodarczej, Warszawa 1932, s. 6 i 11.

${ }^{18}$ Ibidem, s. 26-27 a także Program gospodarczy..., s. 16-17, 88, 91.

${ }^{19}$ Program gospodarczy..., s. 36 i n. oraz s. 60-62.

${ }^{20}$ Dzieje gospodarcze, s. 462.

${ }^{21}$ E. Kwiatkowski, op. cit., s. 373-374.

${ }^{22}$ S. Grabski, Ku lepszej Polsce, Warszawa 1938, s. 207.

${ }^{23}$ Ibidem, s. 122, 170, 214, 239.

${ }^{24}$ O. Lange, Wizje gospodarki socjalistycznej (Wybór pism), Warszawa 1985, s. 133 i n., 141, 211, 252, 253. 
Podobne idee znajdowały w tym czasie wyraz w wielu innych pismach ${ }^{25} \mathrm{i}$ dokumentach ${ }^{26}$.

W podobnym kierunku zmierzał opracowany w latach okupacji przez Zygmunta Zarembę i Tadeusza Szturm de Sztrema Program Polski Ludowej aprobowany przez WRN ${ }^{27}$. Za gospodarką planową wypowiadał się również w swej konspiracyjnej broszurze Stanisław Ossowski, zwracając równocześnie uwagę na związane z nią niebezpieczeństwa oraz postulując ,uspołecznienie, które nie sprowadza się do upaństwowienia"28.

Wśród wypowiedzi, jakie docierały do nas w tym czasie z zagranicy, szczególnie wymowny był program brytyjskiej Labour Party wydany w Warszawie jako druk konspiracyjny (w polskim tłumaczeniu). Postulował on ,planową produkcję na potrzeby ogólnej konsumpcji” oraz szybkie uspołecznienie głównych gałęzi produkcji, połączone z ich ,skoordynowanym planowaniem dla celów ogólnych”29.

Główne ośrodki polityczne i władze Polskiego Państwa Podziemnego stanęły wobec konieczności wypowiedzenia się w tej sprawie. Chodziło przy tym nie tylko o zajęcie zasadniczego stanowiska w kwestii gospodarki planowej, lecz również o bliższe określenie jej charakteru, co do którego zarysowały się w dotychczasowych wypowiedziach bardzo znaczne różnice zdań (od radykalnego uspołecznienia środków produkcji do umocnienia jedynie roli kierowniczej państwa $\mathrm{w}$ gospodarce).

Źródłem trudności były przy tym duże różnice zdań i konflikty pomiędzy stronnictwami politycznymi, na których współdziałaniu opierał się ówczesny ład polityczny ${ }^{30}$. Nie łatwo było w tych warunkach wypracować jednolite stanowisko w kwestiach o tak podstawowym znaczeniu społeczno-politycznym, a nieuniknione kompromisy okazywały się nietrwałe bądź też prowadziły do uzgadniania dokumentów o nie dość wyrazistej treści.

Dokumentem takim była w szczególności Deklaracja Rady Jedności Narodowej z 15 III 1944 r. ${ }^{31}$, która proklamowała oparcie ekonomiki krajowej na zasadach gospodarki planowej oraz objęcie przez państwo funkcji kierowniczych i kontrolnych w gospodarce. Zastrzegała też, że państwo będzie miało prawo

${ }^{25}$ K. Krzeczkowski, Idee przewodnie ubezpieczeń społecznych, Warszawa 1936, s. 183.

${ }^{26}$ J. Tomicki, Polska Partia Socjalistyczna 1892-1948, Warszawa 1983, s. 339-340, a także A. Leinwand, Tadeusz Szturm de Sztrem, Warszawa 1987, s. 129-130.

${ }^{27}$ J. Tomicki, op. cit., s. 419 oraz A. Friszke, O ksztalt Niepodległej, Warszawa 1989, s. 433 i n., a także A. Leinwand, op. cit., s. 129-130.

${ }^{28}$ S. Ossowski, op. cit., s. 38-47.

${ }^{29}$ Nowy Program Brytyjskiej Partii Pracy (Zarys zagadnień przebudowy w czasie wojny i pokoju), WRN (bez r. i m.), s. 11 i n. oraz 29.

${ }^{30}$ Wymowne było wycofanie się Stronnictwa Ludowego z aprobaty Programu Polski Ludowej, pomimo że M. Miłkowski z SL uczestniczył w jego opracowaniu. Por. A. Friszke, op. cit., s. 433 oraz ogólniejszy obraz ówczesnej sceny politycznej ibidem, s. 441 i n.

${ }^{31}$ „Rzeczpospolita Polska”, marzec 1944, numer specjalny. 
„przejmowania lub uspołecznienia” przedsiębiorstw użyteczności publicznej oraz kluczowych przemysłów, transportu i wielkich instytucji finansowych, „w wypadku gdy tego będą wymagały potrzeby ogólne". Ta ostatnia deklaracja miała zatem charakter warunkowy i została wkomponowana w tekst, który przebudowę struktury społeczno-gospodarczej kraju widział przede wszystkim w „upowszechnianiu własności”, tj. ,rozszerzaniu jej na możliwie największą liczbę jednostek gospodarujących".

Punkt ciężkości padał zatem na afirmację podstawowej roli własności prywatnej, i to w postaci warsztatów przemysłowych, rzemieślniczych i handlowych „typu średniego i małego” 32 . Własność miała natomiast stracić charakter „nieograniczonego niczym przywileju osobistego" i być wprzęgnięta w służbę polegającą na „pełnieniu zleconych funkcji społecznych i państwowych”. W treści Deklaracji RJN znalazły ponadto wyraz postulaty wzmocnienia pozycji pracowników i zapewnienia im uczestnictwa w planowaniu społeczno-gospodarczym oraz w nadzorze i kontroli życia gospodarczego.

Tekst ten cechowały niedopowiedzenia, które świadczyły o dążeniu do pogodzenia ze sobą różnych ideowych stanowisk ${ }^{33}$. Kompromis taki nie mógł zadowolić ośrodków politycznych, reprezentujących przeciwstawne punkty widzenia. Deklaracja wzbudzała zasadnicze zastrzeżenia sił zachowawczych ${ }^{34}$. Nie uwydatniała jednak również w pełni stanowiska ośrodków myśli społecznie postępowej, nie tylko wśród stronnictw politycznych, na których opierała się Delegatura Rządu (w szczególności PPS-WRN, a także Stronnictwa Ludowego), lecz również w wojsku ${ }^{35}$ oraz po części w samej Delegaturze, w której poszczególne departamenty nie zawsze były zgodne w ważnych sprawach programowych ${ }^{36}$.

Znaczenie Deklaracji polegało jednak niewątpliwie na afirmowaniu samych zasad gospodarki planowej oraz uspołecznienia w istotnym zakresie środków produkcji ${ }^{37}$, a także przebudowy ustroju rolnego. Kładła ona ponadto nacisk na konieczność uprzemysłowienia kraju i na rozwiązanie podstawowych problemów społecznych (pełne zatrudnienie, wolność od niedostatku).

${ }^{32} \mathrm{O}$ znaczeniu przywiązywanym do tej sprawy świadczyło poświęcenie jej, poza cytowanymi wyżej sformułowaniami, osobnego rozdziału Deklaracji RJN pt. Upowszechnienie własności w miastach (s. 3).

${ }^{33}$ A. Friszke (op. cit., s. 504) widział w tym dążenie do symbiozy idei socjalistycznych ze społeczną nauką Kościoła.

${ }^{34}$ Znalazło to wyraz w zasadniczym zakwestionowaniu treści Deklaracji przez Stronnictwo Narodowe (por. ibidem, s. 507).

${ }^{35}$ Por. ibidem, s. 509 oraz J. Rzepecki, Wspomnienia i przyczynki historyczne, Warszawa 1983, s. $289 \mathrm{in}$.

${ }^{36}$ Por. A. Bień, Bóg jest wyżej, dom jest dalej, „Przedświt”, bez r. i m., s. 71 i 101, gdzie wyeksponowano zwłaszcza różnice stanowisk w kwestii rad zakładowych i reformy rolnej.

${ }^{37}$ Myśl ta została uwydatniona mocniej niż w Deklaracji RJN z 15 III 1944 r. w uchwale Rady Jedności Narodowej z 15 VIII 1944 r. i w opartym na niej memorandum (por. A. Friszke, op. cit., s. 509-510). 
Te ostatnie myśli nawiązywały już wyraźnie do spraw ustroju pracy i polityki społecznej w przyszłej Polsce, ograniczając się jednak do krótkiego ich zasygnalizowania. Nie oznacza to, aby kwestie te nie znalazły uwzględnienia w pracach programowych Delegatury Rządu. Były one rozwijane w pracach jej komórek fachowych: w departamentach, odpowiednio do właściwego im zakresu działania. Problemy ustroju pracy i polityki społecznej stały się przedmiotem szczególnego zainteresowania Departamentu Pracy i Opieki Społecznej, który poprzez swe opracowania koncepcyjne i projekty przygotowywanych aktów prawnych starał się gromadzić materiał przydatny dla komórek centralnych Delegatury oraz pragnął przyczynić się do ostatecznego ukształtowania się jej programu.

O tym, że wpływ taki istotnie miał miejsce, świadczy wyraźnie treść Deklaracji Rady Jedności Narodowej w części poświęconej polityce społecznej38. Dokumenty opracowane przez Departament zarysowały jednak pełniejszą wizję postulowanego ustroju pracy i kierunków rozwoju polityki społecznej. Na tych dokumentach, odpowiadających przedmiotowo treści naszej pracy, skupimy obecnie naszą uwagę.

W kwestii samej akceptacji zasad gospodarki planowej stanowisko Departamentu nie odbiegało na ogół od tego, jakie znalazło wyraz w Deklaracji RJN. Gospodarka planowa stanowiła w ujęciu Departamentu niezbędną przesłankę urzeczywistnienia prawa do pracy ${ }^{39}$ oraz intensywnego uprzemysłowienia kraju i wzmożenia procesu inwestycyjnego ${ }^{40}$. Kierowanie gospodarką miało następować, w koncepcji Departamentu, „W miarę możności przy użyciu metod pośrednich", zakładano jednak, że stosowanie bezpośredniego przymusu będzie w pewnym zakresie niezbędne ${ }^{41}$. Przyjmowano, że ,indywidualne prawo własności środków produkcji nie zostanie uchylone” oraz że „dyspozycja kierownictwem zakładu pracy pozostanie w rękach właściciela"42.

Uznawano jednak równocześnie, że to prawo własności powinno być poddane istotnym ograniczeniom. Postulowano bowiem ,podporządkowanie bezwzględne całego życia społeczno-gospodarczego realizacji ściśle i szczegółowo określonego co do zadań, środków i metod planu gospodarczego", którego założeniem naczelnym miało być skupienie wysiłku całego społeczeństwa wokół intensywnej rozbudowy w celu wyrównania cechującego nasz kraj zacofania i możliwie najszybszego wyrównania zaniedbań z przeszłości ${ }^{43}$. Celowi temu miało służyć „stworzenie centralnej komórki planującej i kierującej działalnością inwestycyjną i wytwórczą w całym państwie"44.

\footnotetext{
${ }^{38}$ Odrębny rozdział Deklaracji RJN (s. 3-4).

${ }^{39}$ Tezy w sprawie polityki zatrudnienia i plac (maszynopis, s. 1, zbiory W.S.).

${ }^{40}$ Ibidem.

${ }^{41}$ Ibidem.

${ }^{42}$ Izby pracy. Opracowanie wstępne dyskusyjne (maszynopis, s. 4, zbiory W.S.).

${ }^{43}$ Ibidem, s. 1 oraz s. 3 (gdzie postulowano dokonanie tych wyrównań „w ciągu życia jednego pokolenia").

${ }^{44}$ Ibidem, s. 3.
} 
Bliższe określenie roli państwa w planowej gospodarce stanowiło oczywiście kwestię o podstawowym znaczeniu. $Z$ treści dokumentów opracowanych w Departamencie wynika, że państwo miało pełnić „funkcję naczelnego kierownictwa i kontroli" ${ }^{45}$ oraz że rola jego miała polegać, jak to sformułowano w innym miejscu, na „nadawaniu kierunku działaniom podmiotów gospodarujących”, obok „stwarzania podstawowych urządzeń gospodarczych”. Zakładało to przeznaczenie znacznych środków na inwestycje publiczne, których kierunek miał być określany przez instytucje planujące ${ }^{46}$.

Bezpośrednie prowadzenie działalności gospodarczej przez państwo przewidywane było natomiast w ograniczonej skali, w dziedzinach nieprzyciągających raczej inicjatywy prywatnej, a więc w przemyśle zbrojeniowym, energetycznym, w przedsiębiorstwach użyteczności publicznej oraz w odniesieniu do niektórych innych wielkich przedsiębiorstw, zwłaszcza przejętych po okupantach ${ }^{47}$.

Całość tych stwierdzeń (zawartych w znacznej części w dokumentach roboczych Departamentu, nacechowanych z natury rzeczy mniejszą precyzją sformułowań niż finalne wypowiedzi programowe) świadczy o akceptowaniu modelu gospodarki planowej, polegającego na wzmożonej roli kierowniczej i kontrolnej państwa nad formami i kierunkami rozwoju gospodarki, przy użyciu przede wszystkim pośrednich środków oddziaływania, a więc instrumentów polityki podatkowej, kredytowej, celnej itp.

Nie oznacza to zasadniczej zmiany ustroju społeczno-gospodarczego, nie podważało bowiem co do zasady prywatnej własności środków produkcji, poddawało natomiast korzystanie z tej własności ograniczeniom, które wynikały z ogólnych założeń planu. Na tym miało polegać „uspołecznienie prawa własności”, rozumiane jako poddanie dyspozycji środkami produkcji - kontroli społecznejes. Inicjatywa prywatna (akceptowana co do zasady) miała być innymi słowy kierowana, co oznaczało związanie przedsiębiorców w ich zasadniczych posunięciach z celami gospodarki planowej, zarówno w odniesieniu do kierunku podejmowanych inwestycji, jak i wysokości zysków, działania monopoli ${ }^{49}$. Postawę Departamentu w kwestii bezpośredniej roli państwa jako przedsiębiorcy cechowała zatem pewna wstrzemięźliwość, która nie wyłączała jednak upaństwowienia dość znacznej części środków produkcji, co pozostawało w zgodzie z programowymi enuncjacjami Delegatury ${ }^{50}$.

W innej natomiast sprawie związanej ściśle z określeniem kierunku przyszłej polityki gospodarczej zarysowało się w Departamencie odrębne stanowisko.

\footnotetext{
${ }^{45}$ Ibidem, s. 3.

${ }^{46}$ Notatka o planowaniu gospodarczym i społecznym (maszynopis, s. 4, zbiory W.S.).

${ }^{47}$ Ibidem, s. 4 i 6, a także: $W$ dążeniu do urzemieślniczenia (maszynopis, s. 2, zbiory W.S.).

${ }^{48}$ Notatka o planowaniu..., s. 6.

${ }^{49}$ Ibidem, s. 5.

${ }^{50}$ Por. przypis 37.
} 
Chodziło mianowicie o tzw. upowszechnienie własności postulowane, jak już wspomniano, w Deklaracji RJN oraz rozwinięte jako podstawowy punkt programu społeczno-gospodarczego w opracowaniu Departamentu Przemysłu ${ }^{51}$. Przeciwko lansowanej w tym dokumencie idei uprzemysłowienia poprzez , jak najszersze rozpowszechnienie placówek wytwórczych”, które miałby cechować „wymiar średni i mały", podniesiono w Departamencie Pracy podstawowe zastrzeżenia. Dotyczyły one zarówno pomniejszania roli państwa, mylnej oceny związku pomiędzy wielkością zakładów przemysłowych a rentownością, jak i zasadniczego nieporozumienia co do walorów społecznych tego programu. Wbrew stanowisku jego autorów, kładących na ten aspekt sprawy szczególny nacisk, Departament Pracy dostrzegał $\mathrm{w}$ powyższym programie zagrożenie dla bezpośrednich interesów pracowników, a także dla kształtowania w nich postaw zaangażowanego współgospodarza oraz umacniania woli pracy i inicjatywy ${ }^{52}$.

Przede wszystkim jednak wyraźne stanowisko Departamentu Pracy zaznaczyło się w kwestii społecznych treści gospodarki planowej polegających na ograniczeniu wpływu biurokracji państwowej i „otamowaniu twórczości urzędników" ${ }^{53}$. Zasadnicza rola do odegrania miała, zdaniem Departamentu, przypadać pochodzącym z wyboru organom samorządu społeczno-gospodarczego, do którego należeć miało, po ustaleniu ogólnych wytycznych planu, opracowanie planów szczegółowych i zadań do wykonania, przy uwzględnieniu postulatów wysuwanych ze strony organów reprezentujących różne interesy gospodarcze. Samorząd, o którym mowa, miał tym samym ,przejąć funkcje kierownicze w zakresie wykonawstwa" planów szczegółowych. W skład struktury samorządu społeczno-gospodarczego miały wchodzić organy reprezentujące różne dziedziny życia gospodarczego, a więc izby: przemysłowe, rzemieślnicze, rolnicze i izby pracy, powołane nie tak, jak to zakładano w okresie międzywojennym, do reprezentowania partykularnych interesów, lecz do przezwyciężania zachodzących między nimi sprzeczności, tak aby produkcja i całość życia gospodarczego była „podporządkowana interesom wspólnoty narodowej” ${ }^{4}$.

${ }^{51} \mathrm{~W}$ dążeniu do uprzemystowienia (maszynopis, s. 32, zbiory rodziny M. Święcickiego).

${ }^{52}$ Znalazło to wyraz w polemicznej notatce noszącej ironicznie zabarwiony tytuł: $W$ dążeniu do urzemieślniczenia i piętnującej dostrzegany w krytykowanym dokumencie „wzór społeczny drobnomieszczaństwa" (maszynopis, s. 2, zbiory W.S). Autorem tego opracowania był Wacław Iwaszkiewicz, a treść jego była jednak zgodna z poglądami przyjętymi w Departamencie Pracy. Pośrednio świadczą o tym notatki krytyczne Stefana Matei na marginesach tamtego dokumentu. W zbiorach Departamentu Pracy zachowało się również nieco obszerniejsze opracowanie krytyczne pt. Uwagi do rozważań zatytułowanych „, W dażeniu do uprzemysłowienia” (maszynopis, s. 4, zbiory W.S.). Treść tego dokumentu odpowiada stanowisku Departamentu Pracy oraz szerzej je rozwija i uzasadnia. Autorstwa i przeznaczenia tego opracowania nie udało mi się jednak ustalić.

${ }^{53}$ Notatka o planowaniu..., s. 7.

${ }^{54}$ Izby pracy..., s. 3-4. W tej materii wyraźny wpływ na poglądy Departamentu wywarły prace Jana Hoppego z ostatnich lat przed wojną i z okresu okupacji w ramach „Unii”, z którą był 
Stanowisko to wynikało z zasadniczego założenia, że planowa intensywna rozbudowa gospodarki jest ,zgodna $\mathrm{z}$ ostatecznymi postulatami wszystkich klas społecznych" oraz że główna uwaga musi być skupiona na produkcji zwiększającej dochód narodowy, a nie na konsumpcji i problemach jego podziału ${ }^{55}$. Imperatyw taki narzucał się istotnie jako oczywisty, zwłaszcza w pierwszej fazie dźwigania kraju ze zniszczeń wojennych. Można też było w tym czasie oczekiwać ze strony szerokich kręgów społeczeństwa dużego zaangażowania na rzecz działań służących dobru ogólnemu. Sprawa „podnoszenia dobrobytu klas pracujących" musiała być z konieczności przesunięta na plan dalszy, trzeba było jednak od początku gospodarować w sposób uwzględniający konieczność zaspokajania niezbędnych elementarnych potrzeb szerokich kręgów ludnościs ${ }^{56}$.

Wzmożony wysiłek produkcyjny i gotowość do ponoszenia ofiar miały być natomiast kompensowane przez wzmocnienie pozycji czynnika pracy i jego wpływu na kierunek polityki społeczno-gospodarczej państwa. Taki cel przyświecał zamierzonemu utworzeniu izb pracy, które miały zapewnić światu pracy „samodzielne uczestnictwo $\mathrm{w}$ rozwiązywaniu zagadnień społeczno-gospodar-

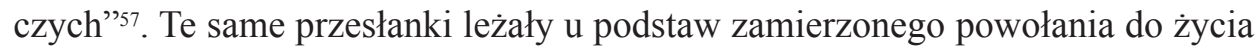
rad zakładowych, które miały normować życie wewnętrzne zakładu pracy oraz oceniać i rozstrzygać w szerokim zakresie sprawy zakładu, ograniczając w ten sposób arbitralną władzę kierownika ${ }^{58}$. Niezmiernie ważne $\mathrm{z}$ tego punktu widzenia było wzmocnienie struktury związków zawodowych, których naczelnym zadaniem miały być, w odróżnieniu od poprzednio wymienionych instytucji, obrona i przedstawicielstwo zbiorowych interesów pracowników, poprzez uczestniczenie w procedurach pojednawczo-rozjemczych, zawieranie układów zbiorowych i organizowanie strajków.

Wokół tych trzech instytucji: izb pracy, związków zawodowych i rad zakładowych, uznanych za podstawowe filary przyszłego ustroju pracy, skupiła się szczególna uwaga Departamentu. Znalazło to wyraz w ukierunkowaniu jego opracowań programowych i projektów aktów prawnych, które właśnie w tej dziedzinie zostały najbardziej zaawansowane. Świadczy o tym treść ostatniego sprawozdania Departamentu przesłanego Rządowi RP w Londynie ${ }^{59}$. Wymowne było

związany Stefan Mateja. Por. J. Hoppe, Samorząd Pracy, Warszawa 1932 oraz idem, Wspomnienia, przyczynki, refleksje, Londyn 1972, s. 76 i n. Do wątku tego nawiążemy w rozdziale III.

${ }_{55}^{5}$ Izby pracy..., s. 1-2.

${ }^{56}$ Ibidem, s. 4 i 5.

${ }^{57}$ Izby Pracy, zał. 3 do Sprawozdania z działalności Departamentu Pracy i Opieki Społecznej za I kwartat 1944, przestanego do Londynu, CA KC PZPR 202/I-34, t. 1, s. 66-86. Cytat dotyczy tezy 1 tego załącznika.

${ }^{58}$ Art. 5 Rozporzadzenia Krajowej Rady Ministrów z dnia 1 VIII 1944 r. o radach zakładowych, Dz. U. 1944, cz. III, nr 2, poz. 16.

${ }^{59}$ Izby Pracy, zał. 3 do Sprawozdania z działalności..., s. 2-3. 
również opublikowanie dekretu o radach zakładowych w „Dzienniku Ustaw”, wydawanym w czasie powstania warszawskiego ${ }^{60}$.

Do wzmocnienia pozycji ludzi pracy miała się też w istotny sposób przyczynić „likwidacja gospodarczej zbędności milionowych mas” oraz szerokie zapewnienie „możliwości awansu poprzez pracę” ${ }^{\prime 1}$. Osiągnięcie stanu pełnego zatrudnienia było jednym z podstawowych postulatów społecznych Departamentu. Wydawało się przy tym w okresie powojennym realne, ze względu na zarysowującą się perspektywę zasadniczej zmiany na rynku pracy: zmniejszenie się globalnej podaży pracy wskutek ubytku ludności spowodowanego przez wojnę i politykę eksterminacyjną okupantów, a z drugiej strony wydatne zwiększenie liczby miejsc pracy poza rolnictwem, w związku z przejęciem zakładów przemysłowych na nowych ziemiach. W szacunku tym należało wprawdzie uwzględnić zniszczenia wojenne, zakładano jednak, że w ostatecznym wyniku nie wystąpi poważniejszy niedobór miejsc zatrudnienia, który tak dramatycznie ciążył na rynku pracy w okresie międzywojennym.

Sytuację mogła natomiast komplikować niekorzystna struktura powojennej podaży pracy: niedobór kwalifikowanych kadr i nadmiar sił niekwalifikowanych. Wynikał stąd postulat podjęcia z jednej strony intensywnej akcji szkolenia, doszkalania i doskonalenia zawodowego, a z drugiej strony uruchomienia na szeroką skalę pracochłonnych robót publicznych, objętych planem odbudowy kraju ze zniszczeń wojennych ${ }^{62}$.

Pełne zatrudnienie musiałoby zmienić samo przez się sytuację na rynku pracy, zwiększając szanse pracowników na poszanowanie ich praw i interesów. Perspektywicznie powinno to przynieść również wzrost dochodów z pracy, tym bardziej że należało liczyć się z silnym oddziaływaniem w tym kierunku odbudowanych na nowych zasadach związków zawodowych. Nie mogło to jednak nastąpić bezpośrednio po wojnie, ani w paroletnim okresie przejściowym, w którym należało realistycznie oczekiwać dużych trudności gospodarczych i w związku z tym niskiego poziomu płac, uzupełnianych przez świadczenia rzeczowe (deputaty) ${ }^{63}$.

Pełne zatrudnienie nie gwarantowało również samo przez się przezwyciężenia towarowego stosunku do pracy. W tym celu było konieczne, według Departamentu, nie tylko wzmocnienie pozycji pracowników na rynku pracy przez likwidację bezrobocia, lecz ponadto dokonanie zmiany przepisów prawa regulującego treść stosunków pracy. Zmiana ta miała przy tym polegać nie tylko

${ }^{60}$ Por. przypis 58. Należy zauważyć, że dwa akty prawne spośród opublikowanych w dwóch numerach „Dziennika Ustaw” w czasie powstania warszawskiego dotyczą polityki społecznogospodarczej. Przedmiotem ich były rady zakładowe (poz. 16) i zabezpieczenie ziemi na cele przebudowy ustroju rolnego (poz. 9). Oba opublikowane w Dz. U. 1944, nr 2.

${ }^{61}$ Izby Pracy, zał. 3 do Sprawozdania z działalności..., s. 1 i 3.

${ }^{62}$ Ibidem, s. 4.

${ }^{63}$ Tezy w sprawie polityki płac, zał. 5 do Sprawozdania z działalności..., pkt B, s. 2-3. 
na zwiększeniu uprawnień pracowniczych w ramach dotychczasowych konstrukcji prawnych, lecz również na przebudowie tych konstrukcji, połączonej z przekształceniem ich charakteru. U podstaw tych koncepcji leżało przekonanie, że umowno-zobowiązaniowa więź prawna między pracodawcą a pracownikiem, nawet podporządkowana przepisom prawa bezwzględnie obowiązującego, nie zapewni jeszcze pracownikowi dostatecznej ochrony.

Postulowano w związku z tym zmianę samego charakteru tej więzi przez nadanie stosunkowi pracy charakteru „gotowej sytuacji prawnej”, wyłączonej całkowicie ze sfery indywidualnych rokowań między stronami. Określano to jako ,instytucjonalizację” stosunków pracy, oznaczającą przeniesienie ich ze sfery prawa zobowiązaniowego (cywilnego) do prawa publicznego ${ }^{64}$. Koncepcja ta wyrastała z przekonania, że prawo umowne (zobowiązaniowe) nie jest w stanie zapewnić skutecznej ochrony interesów pracownika, nawet przez rozbudowę przepisów bezwzględnie obowiązujących, co stanowiło zresztą od początku cechę charakterystyczną prawa pracy w odróżnieniu od prawa cywilnego. Nie podważało to umownej podstawy wstępowania w stosunki pracy oraz wolności wyboru miejsca pracy i zawodu ${ }^{65}$. Natomiast wyłączenie umownego decydowania o warunkach pracy i płacy zostało uznane za niezbędne w celu oderwania się od mechanizmów rynkowych, upodobniających pracę do towaru ${ }^{66}$.

Reminiscencje z okresu międzywojennego obok atrakcyjności modelu gospodarki planowej zaważyły decydująco na tych koncepcjach, nadając im charakter przerysowany i wskutek tego niezbyt przekonywający. Sprawie tej poświęcimy bliższą uwagę $\mathrm{w}$ rozdziale dotyczącym prawa pracy. Na razie ograniczymy się natomiast do stwierdzenia, że przezwyciężenie towarowego stosunku do pracy, ze wszystkimi płynącymi stąd następstwami, zależało przede wszystkim od sytuacji na rynku pracy oraz od układu sił społecznych, a w dużo mniejszym stopniu od treści i charakteru przepisów prawnych nawet wyposażonych w najostrzejsze rygory.

Od regulacji prawnej zależało natomiast $\mathrm{w}$ decydującej mierze określenie treści uprawnień przysługujących różnym kategoriom pracowników oraz ich zróżnicowanie. Stan prawny w okresie międzywojennym był, jak wiadomo, w tym zakresie wysoce niezadowalający, gdyż stwarzał nieuzasadnione społecznie linie podziału i upośledzał niektóre kategorie pracowników, wyłączając ich z zakresu podmiotowego podstawowych przepisów prawa pracy.

Departament Pracy wystąpił zdecydowanie przeciwko tym nieprawidłowościom, formułując postulat ,jedności pracowniczej” ${ }^{67}$, wyłączającej dopuszczal-

\footnotetext{
${ }^{64}$ Zasady nowego prawa pracy (maszynopis, s. 3-4, zbiory W.S.) oraz Tezy w sprawie indywidualnego prawa pracy. Uwagi ogólne (maszynopis, s. 2, zbiory W.S.).

${ }^{65}$ Tezy w sprawie polityki zatrudnienia, zał. 4 do Sprawozdania z działalności..., s. 2, teza D. 2.

${ }^{66}$ S. Mateja, Opieka nad pracownikiem jako obowiazek pracodawcy, maszynopis, BUŁ, s. 107.

${ }^{67}$ Zasady nowego prawa..., s. 1.
} 
ność przyjętego z góry podziału pracowników na „,sztywno rozgraniczone kategorie" oraz przywilejów stwarzających ,nieuzasadnione społecznie rozbicie wśród warstwy pracowniczej" ${ }^{68}$. Wynikało to z zasadniczego założenia, że w przyszłej organizacji życia zbiorowego trzeba unikać wszystkiego, ,co społeczeństwo dzieli, przeciwstawia i rozprasza”, przyczynić się natomiast do „popierania wysiłków i działań umacniających i jednoczących"69.

Z założeniami tymi niezgodny był ,apriorycznie przyjęty” podział pracowników na fizycznych (robotników) i umysłowych, a także wyłączenie poza obręb ustawodawstwa pracy robotników rolnych. Zakwestionowano również z tego punktu widzenia odrębny status funkcjonariuszy państwowych (urzędników), uznając że charakter ich pracy tego nie uzasadnia ${ }^{70}$. „Jedność pracownicza” oznaczała oparcie wszystkich stosunków pracy na wspólnych zasadach i odrzucenie linii podziału, stawiających jednych pracowników w pozycji uprzywilejowanej, a innych w upośledzonej. Nie wyłączała natomiast dyferencjacji uprawnień opartych na kryteriach rzeczowych, związanych z charakterem i warunkami pełnionej pracy (np. w zakresie regulacji czasu pracy czy urlopów wypoczynkowych). Akceptowano również w pełni, ze względów społecznych, odrębną regulację sytuacji prawnej kobiet i młodocianych ${ }^{71}$.

Dążenie do oparcia wszelkich różnic w treści uprawnień pracowniczych na kryteriach rzeczowych objęło również politykę płac, kojarząc się z tendencją do wyrwania ich ze sfery zależności rynkowych („towarowych”). Taki sens miał postulat „obiektywizacji płac”72, której kryteria nie zostały jednak bliżej określone.

Wychodząc z tych samych przesłanek, postulowano jednolity dla wszystkich pracowników powszechny system ubezpieczeń społecznych, który miał w przyszłości objąć także osoby samodzielnie zarobkujące, poza rolnictwem. Zakładano przy tym, że świadczenia udzielane w ramach tego systemu będą utrzymane na poziomie minimum „realnie zapewniającego skromne utrzymanie”, natomiast troska o środki powyżej tego minimum miała być pozostawiona zaradności indywidualnej i zbiorowej. Ta ostatnia miała w szczególności przybierać formę ubezpieczeń dodatkowych, o charakterze fakultatywnym.

W ubezpieczeniach społecznych miał działać samorząd o szerokich kompetencjach, ściśle powiązany z organami samorządu społeczno-gospodarczego (izby) oraz z ruchem zawodowym. Lecznictwo ubezpieczeniowe miało współdziałać z powszechną służbą zdrowia, przy czym punkt ciężkości przyszłych

\footnotetext{
${ }^{68}$ Plan pracy: Uwagi ogólne na temat potrzeby reformy przepisów o indywidualnym stosunku pracy (maszynopis, s. 3, zbiory W.S.).

${ }^{69}$ Zasady nowego prawa..., s. 1-3.

${ }^{70}$ Tezy w sprawie indywidualnego prawa..., teza 3.

${ }^{71}$ Zasady nowego prawa..., s. 1-3.

${ }^{72}$ Tezy w sprawie polityki płac, zał. 5 do Sprawozdania z działalności..., s. 2, teza II A 5.
} 
rozwiązań leżał raczej w tej ostatniej dziedzinie ${ }^{73}$. Służba zdrowia miała być docelowo oparta na sieci szpitalno-ambulatoryjnej, rozbudowanej na wszystkich szczeblach samorządu terytorialnego (w szczególności w powiatach i w województwach). Źródłem poważnych trudności w tej dziedzinie był jednak deficyt fachowych kadr (lekarzy i personelu pomocniczo-lekarskiego), a także urządzeńn ${ }^{74}$.

W dziedzinie opieki społecznej należało liczyć się z ogromem potrzeb, zwłaszcza w okresie bezpośrednio powojennym, co wymagało maksymalnego zmobilizowania siłi środków. Duża rola do odegrania miała tu przypaść Polskiemu Komitetowi Opiekuńczemu, utworzonemu na bazie aparatu Rady Głównej Opiekuńczej, która działała w czasie okupacji. Liczono się też z rozwojem samorzutnej samopomocy i inicjatywy społecznej. Ogólne kierownictwo i decydowanie o sprawach podstawowych w dziedzinie opieki społecznej miało być jednak skoncentrowane w rękach organów administracji publicznej ${ }^{75}$.

Całość powyższych koncepcji opierała się na podstawowych założeniach programowych, określających wizję przyszłej Polski. Szczególną rolę odgrywała wśród nich sformułowana przez Departament idea ustroju opartego na pracy, wyrażająca najważniejsze elementy przyszłego porządku społeczno-gospodarczego. Oznaczała ona nie tylko powszechną dostępność pracy, odpowiadającej indywidualnym kwalifikacjom i uzdolnieniom, lecz również stworzenie hierarchii społecznej, której podstawowym kryterium powinny być: rodzaj i jakość spełnianej pracy oraz jej ważność dla dobra wspólnoty narodowej. To właśnie kryterium, a nie jakiekolwiek inne względy, powinno decydować o pozycji społecznej i sytuacji materialnej jednostek. Takie było ideowe podłoże przedstawionych wyżej koncepcji ,jedności pracowniczej” (przezwyciężającej niesprawiedliwe linie podziału), a także „instytucjonalizacji stosunku pracy” (zapobiegającej nieuzasadnionemu zróżnicowaniu uprawnień wbrew powyższemu kryterium) oraz „obiektywizacji płac".

Idea ustroju opartego na pracy określała również pozycję społeczną inteligencji, o czym miały decydować jej rzeczowe kwalifikacje przejawiane w pełnionej przez nią pracy, a nie jakiekolwiek inne względy, związane z urodzeniem, przynależnością do uprzywilejowanych kręgów społecznych czy posiadanym majątkiem. Wychodząc z tych założeń, należało afirmować kierowniczą rolę inteligencji, jako grupy ludzi twórczych i wysoko kwalifikowanych, co nie uzasadniało

\footnotetext{
${ }^{73}$ Sprawozdanie z działalności..., s. 5 oraz Wytyczne projektu powszechnych ubezpieczeń społecznych, zał. 6 do Sprawozdania z działalności..., zwłaszcza tezy 1-3, 6, 13, 14, 15.

${ }^{74}$ Sprawozdanie z działalności..., s. 5.

${ }^{75}$ Ibidem, s. 6. Dział opieki społecznej należał do najsłabiej opracowanych tematów przez Departament.
} 
jednak przyznawania im w jakiejkolwiek mierze pozycji uprzywilejowanej ani odrębnego statusu prawnego ${ }^{76}$.

Budowa ustroju opartego na pracy była traktowana jako jeden z podstawowych celów polityki społecznej, która nabierała w koncepcji Departamentu szerokiej treści, wykraczającej poza funkcje ochronne, co nie oznaczało odsuwania ich na dalszy plan, lecz wynikało z przeświadczenia, że do nich nie będzie można się ograniczyć. Do zadań polityki społecznej włączano politykę płac przez akcję wychowawczą i propagandową, ale także przez oddziaływanie w kierunku uznania samego pełnienia pracy za obowiązek obywatelski. Polityka społeczna miała również przyczyniać się do podnoszenia kwalifikacji przez szeroko zakrojoną akcję szkolenia zawodowego i eksperymentowanie nowych jego metod. Miała też wnosić swój wkład do gospodarki planowej, przez wpływanie na racjonalne przemieszczanie pracowników i optymalne wykorzystanie ich zdolności i zainteresowań, sprzyjające wyzwalaniu „maksimum dobrowolności i zapału”, a więc rozbudzaniu pozytywnych postaw i inicjatywy.

Polityka społeczna miała zatem być „pozytywna i twórcza w swym nastawieniu, a nie tylko ochronna w stosunku do czynnika pracy”. Miała być też integralna, a więc obejmować „całokształt zagadnień socjalnych, a nie tylko związane ze światem pracy najemnej”, co przejawiało się m.in. w postulatach rozszerzenia zakresu ubezpieczeń społecznych i służby zdrowia na całą ludność kraju. Postulowana polityka społeczna miała wreszcie być „współrzędna i ściśle powiązana z polityką gospodarczą", w czym przejawiała się podwójna myśl. Chodziło bowiem z jednej strony o podkreślenie wspólnoty zasadniczych celów oraz znaczenia wkładu, jaki polityka społeczna może i powinna wnosić do rozwoju gospodarki, nie ograniczając się do czerpania z nagromadzonych przez nią zasobów. Równocześnie jednak, z drugiej strony, w planowaniu rozwoju polityki społecznej należało liczyć się z „,realnymi możliwościami uwarunkowanymi stanem gospodarczym kraju", broniąc się przed myśleniem życzeniowym i formułowaniem postulatów, które nie miały w danym czasie szans urzeczywistnienia $^{77}$.

Obie postawy znalazły wyraz w szczegółowych opracowaniach programowych Departamentu. Pierwsza z nich - zwłaszcza w projektowaniu przyszłej polityki zatrudnienia i podstaw nowego ustroju pracy. Druga - w trzeźwym podejściu do kształtowania poziomu świadczeń powszechnego ubezpieczenia społecznego. W istocie jednak całość przedstawionych myśli programowych znalazła odbicie w koncepcjach i projektach dotyczących poszczególnych części składowych ustroju pracy i polityki społecznej.

${ }^{76}$ Idee przewodnie polityki społecznej (maszynopis bez tytułu, pkt 18, zbiory W.S.). Końcowe stwierdzenie dotyczy w szczególności odrębnego prawa pracy ,pracowników umysłowych”. Nie odrzucano natomiast potrzeby odrębnych regulacji, uzasadnionych szczególnym charakterem pełnionej pracy, np. w odniesieniu do lekarzy czy nauczycieli.

${ }^{77}$ Ibidem, tezy 14-19. 
W dalszych częściach niniejszego opracowania zajmiemy się nimi bliżej, skupiając kolejno uwagę: na ustroju pracy, prawie pracy, ubezpieczeniach społecznych i służbie zdrowia oraz na innych zagadnieniach socjalnych, dotyczących zwłaszcza opieki społecznej. Przed tym jednak trzeba jeszcze zająć się problematyką polityki zatrudnienia i płac, której przedstawienie wykraczałoby poza ramy tematyczne niniejszego rozdziału, a równocześnie powinno wyprzedzać rozważania mające za przedmiot ustrój i prawo pracy oraz ubezpieczenia społeczne i zagadnienia pokrewne. 



\section{Praca i placa}

Przewidywaniom Departamentu Pracy na przyszłość towarzyszyła, jak już wspomniano, nadzieja, że osiągnięcie stanu pełnego zatrudnienia po wojnie będzie łatwiejsze niż w latach trzydziestych. Była to jednak nadzieja daleka od pewności, a nawet od przekonania opartego na konkretnych przesłankach. Wszelkie prognozy i projekty z tamtych lat musiały być formułowane w obliczu wielu niewiadomych. Trudno by przewidzieć, jak ukształtuje się ostatecznie bilans: $z$ jednej strony szkód i strat materialnych, a z drugiej strony ubytku żywych sił ludzkich, zdolnych do podjęcia pracy. Nie sposób było określić, jakie szkody dadzą się w ciągu niezbyt długiego czasu odrobić, a jakie okażą się trwałe czy nieodwracalne. Podobnie nie można było mieć bliższego wyobrażenia o tym, w jakiej kondycji przetrwają ludzie $\mathrm{w}$ wieku produkcyjnym i jakie będą reprezentowali kwalifikacje fachowe. W Delegaturze Rządu były opracowywane sukcesywnie informacje i prognozy ogólne $\mathrm{z}$ tego zakresu', uwzględniające dane o stwierdzanych faktach, miały one jednak wyłącznie znaczenie orientacyjne.

Niewątpliwie należało się liczyć z ogromnymi ruchami migracyjnymi ludności i to na skalę przekraczającą o wiele migracje i przemieszczenia, jakie wystąpiły po I wojnie światowej, stwarzając wtedy wiele problemów². Zarysowywała się w związku z tym myśl o potrzebie ujęcia tych ruchów w zorganizowane formy. Kiełkowała idea opracowania planów zatrudnienia i przemieszczania ludności zharmonizowanego z planem przebudowy społeczno-gospodarczej kraju i obsadzenia nowych ziem, a także reform ustroju rolnego ${ }^{3}$. Było jednak rzeczą jasną, że dynamika przewidywanych ruchów ludności nie da się w pełni opanować i że stworzy wiele problemów wymagających bezpośredniego reagowania. Wynikało stąd szczególne zadanie dla polityki zatrudnienia w okresie przejściowym lat

\footnotetext{
${ }^{1}$ Przede wszystkim przez Departament Informacji i Prasy Delegatury Rządu. W aktach Departamentu Pracy zachowała się notatka pt. Statystyka populacyjna na koniec 1943 r. (XX CK 1-2) oraz niektóre inne materiały.

${ }^{2}$ Por. Polityka Spoleczna Państwa Polskiego (1918-1935), Warszawa 1935, s. 191 i n.

${ }^{3}$ Tezy w sprawie polityki zatrudnienia i płac (AAN, MPiOS 12, s. 198-206 oraz w zbiorach W.S.), teza 13.
} 
powojennych, gdy należało przewidywać, że pośrednictwo pracy będzie się musiało łączyć z udzielaniem różnego rodzaju pomocy, zwłaszcza osobom powracającym do kraju. Nieuniknione wydawało się w tej mobilnej sytuacji wystąpienie bezrobocia, rozładowywanego stopniowo w miarę uruchamiania zakładów pracy, w których podjęcie produkcji nie wymagałoby poważniejszych nakładów inwestycyjnych.

Szczególnych trudności należało oczekiwać ze względu na przewidywany niedobór wykwalifikowanych kadr, którego wyrównanie nie było możliwe w krótkim czasie. Narzucały się w związku z tym dwa kierunki działania. Jeden z nich stanowiło podjęcie doraźnej akcji przeszkalania i doszkalania zawodowego, w zakresie najkonieczniejszym, odpowiednio do potrzeb chwili. Drugi kierunek to zastosowanie szczególnych rygorów, zapewniających optymalne spożytkowanie istniejących wykwalifikowanych kadr w zawodach o kluczowym znaczeniu dla życia kraju. Miałoby to polegać na ograniczeniu w tych zawodach swobody zawierania i rozwiązywania umów o pracę, a zwłaszcza na wprowadzeniu instytucji tzw. powołania do pracy, równoznacznego z nakazem jej podjęcia.

Zachowane materiały Departamentu Pracy ${ }^{4}$ świadczą o zamierzeniach zastosowania tego trybu w dość szerokiej skali, przy równoczesnym dążeniu do złagodzenia jego bezpośrednio administracyjnego charakteru. Celowi temu miało służyć powierzenie wykonawstwa w tym zakresie różnym instytucjom zawodowym, predestynowanym do pełnienia tej roli, przy zastrzeżeniu szczególnych uprawnień dla organów samorządu społeczno-gospodarczego (właściwych izb). Było to podyktowane tendencją do maksymalnej elastyczności w działaniu oraz do stymulowania inicjatyw społecznych, mogących prowadzić do dobrowolnego podejmowania stanowisk pracy i w ten sposób zapobiegać potrzebie stosowania trybu nakazowego. Wiązała się z tym myśl o uznaniu pełnienia pracy na pewnych stanowiskach za swego rodzaju wyróżnienie społeczne, pomimo stwarzanych przez nią niedogodności.

Nie zmieniało to jednak faktu, że tryb powoływania do pracy miał wiązać się z rygorami administracyjnymi i stosowaniem sankcji karnych „na wypadek złamania obowiązku". Przewidywano natomiast świadczenia służące łagodzeniu szczególnych uciążliwości (zwłaszcza zasiłki w razie konieczności rozłąki z rodziną). Podkreślano mocno wyjątkowy charakter nakazowego trybu powoływania do pracy, uzasadniony przewidywanym ostrym niedoborem kwalifikowanych kadr w okresie bezpośrednio powojennym. Stosowanie tego trybu miało być tym samym ograniczone do okresu przejściowego 5 .

\footnotetext{
${ }^{4}$ Notatka pt. Uzasadnienie dekretu o powoływaniu do pracy (maszynopis, s. 2, zbiory rodziny M. Święcickiego). Tekst samego projektu dekretu się nie zachował.

${ }^{5}$ Zasady polityki zatrudnienia okresu przejściowego zostały szerzej rozwinięte w cytowanych już Tezach $w$ sprawie polityki zatrudnienia... przesłanych w czerwcu 1944 r. do Londynu (AAN, MPiOS 12, s. 127 i n.), Była to II wersja dwóch połączonych dokumentów: Tez w sprawie
} 
W polityce zatrudnienia wykraczającej poza ten okres szczególnego znaczenia nabierało określenie charakteru kierowniczej roli państwa oraz form jej urzeczywistniania, zapewniających optymalne spożytkowanie sił ludzkich i ograniczenie do minimum zjawiska bezrobocia i zbędności. Działanie w tym kierunku nie mogło obejść się bez pewnych rygorów i nacisków, wymagało bowiem „planowego kształtowania rynku pracy", stanowiącego odpowiednik postulowanej planowości w całej gospodarce. Nie powinno również, bez koniecznej potrzeby, ograniczać sfery swobód obywatelskich, objętych pojęciem wolności pracy. Należyte wyważenie tych elementów miało charakter kluczowy, decydujący o obliczu przyszłej polityki zatrudnienia. Należało przy tym liczyć się z trudnościami w rozwiązywaniu tego problemu i to nie tylko (co łatwo zrozumieć) w okresie przejściowym, lecz również w latach późniejszych ze względu na długotrwałe skutki wojny i okupacji w całej gospodarce.

Deklarowana expressis verbis przez Departament zasada wolności wyboru miejsca pracy i zawodu ${ }^{7}$ nie stała na przeszkodzie wprowadzeniu rygorów porządkowych, polegających na obowiązku informowania organów zatrudnienia o zmianach miejsca pracy czy też nawet obowiązku korzystania z państwowego pośrednictwa pracy, zwłaszcza gdyby miał on być wprowadzany w ograniczonym zakresie ${ }^{8}$ i dotyczyć przede wszystkim pracodawców ${ }^{9}$. Rygory takie służyły bowiem przede wszystkim uzyskaniu pełnych danych o procesach zachodzących na rynku pracy, w celu lepszego obsługiwania jego potrzeb. Niektóre zamierzenia i tendencje wyrażone w dokumentach programowych Departamentu wykraczały jednak poza ten zakres.

Należy tu wskazać przede wszystkim na wyraźnie sformułowany, i to jako naczelna zasada, powszechny obowiązek pracy ${ }^{10}$. Charakter tego obowiązku nie został wprawdzie jasno sformułowany, można go było przeto rozumieć jako moralną powinność obywatelską. Niektóre sformułowania zawarte w tezach Departamentu zdawały się przemawiać za taką interpretacją, zwłaszcza gdy wiązały urzeczywistnienie obowiązku pracy z przemianą pojęć społecznych i powszechnym postępem społecznym, albo gdy traktowały omawiany obowią-

polityki zatrudnienia oraz Tez w sprawie polityki płac, które stanowiły załącznik do sprawozdania Departamentu za I kwartał 1944 r., przesłanego do Londynu (CA 202/I-34, t. 1, s. 78-84). W tekście dotyczącym zatrudnienia wystąpiły pomiędzy obydwiema wersjami pewne różnice wynikające stąd, że w II wersji uwzględniono zmiany wprowadzone przez Komitet Ekonomiczny KRM. Na różnice te wskazuje się poniżej. Natomiast tekst dotyczący płac jest w obu wersjach niemal identyczny. Wymienione dokumenty są cytowane dalej jako „tezy Z I”, „tezy P I” oraz „tezy ZP II”.

${ }^{6}$ Tezy ZP II, 9.

${ }^{7}$ Tezy ZP II, 21a także tezy Z I, D 2 i 11.

${ }^{8}$ Tezy Z I, D 5.

${ }^{9}$ Tezy ZP II, 23.

${ }^{10}$ Tezy ZP II, 11a oraz tezy Z I, B 1. 
zek jako „podstawową zasadę życiową"11. W sformułowaniach tych można było dostrzegać raczej dążenie do oddziaływania metodami pośrednimi w kierunku potęgowania woli pracy i mobilizowania sił społecznych, aniżeli wymuszania określonych zachowań za pomocą rygorów prawnych. W niektórych tezach położono zresztą expressis verbis główny nacisk na „budzenie pożądanych postaw i bodźce psychiczne" oraz na zachętę materialną. Dostrzegano równocześnie niezbędność użycia w pewnym zakresie środków przymusu, w celu ,podporządkowania interesów osobistych i grupowych nadrzędnym celom wspólnoty" ${ }^{\prime 2}$. Wskazywano też na potrzebę „stosowania administracyjnych środków kierowania zatrudnieniem”'13. I wreszcie wypowiadano się wyraźnie za stosowaniem „bezpośredniego przymusu" wobec osób uchylających się od pracy ${ }^{14}$. Te ostatnie tezy były przy tym formułowane $\mathrm{z}$ myślą o trwalszym zastosowaniu, nie tylko $\mathrm{w}$ okresie przejściowym.

Wynikało to z uznania za absolutny priorytet „wprzęgnięcia do pracy nad przebudową kraju wszystkich sił ludzkich"15 i to w ciągu całego okresu niezbędnego dla dopełnienia dzieła przebudowy. Usprawiedliwiało to w oczach Departamentu odstąpienie od norm międzynarodowego prawa pracy, ograniczających pracę przymusową i obowiązkową ${ }^{16}$. Ideą przewodnią Departamentu była pełna mobilizacja sił ludzkich do prac służących dobru kraju, co z reguły miało następować w drodze swobodnego wyboru miejsc zatrudnienia i tylko w stosunku do (nielicznych, jak należało przypuszczać) osób opornych miało oznaczać zastosowanie środków przymusu. Precyzowano tę myśl stwierdzając, że „w ramach powszechnego obowiązku pracy będzie istniała swoboda zmiany zawodu i miejsca pracy" ${ }^{17}$, co rzucało również bliższe światło na pojmowanie treści tego obowiązku. Ograniczenia tej swobody były przewidywane, jak już wspomniano, jedynie w okresie przejściowym, w zawodach mających szczególne znaczenie społeczno-gospodarcze.

Odpowiednikiem powszechnego obowiązku pracy miał być w stosunku do młodzieży obowiązek nauki zawodu, którego wprowadzenie leżało $\mathrm{w}$ istocie w jego interesie, służyło bowiem nabywaniu kwalifikacji zwiększających szanse zatrudnienia i otwierało drogę awansu społecznego. Bezpośrednie wykonawstwo miało w tej dziedzinie należeć do organów zatrudnienia w ścisłym współdziałaniu

${ }^{11}$ Tezy Z I, B 1.

${ }^{12}$ Tezy ZP II, 4 i 21.

${ }^{13}$ Tezy Z I, D 4.

${ }^{14}$ Tezy ZP II, 21. Koncepcja przymusowego zatrudnienia osób uchylających się od pracy wystąpiła w tej wersji tez. W tezach Z I nie było o niej mowy.

${ }^{15}$ Tezy ZP II, 14.

${ }^{16}$ Konwencja nr 29 MOP z 1930 r. Bardziej stanowcza konwencja nr 105 MOP o zniesieniu pracy przymusowej została przyjęta dopiero w $1957 \mathrm{r}$. Obie konwencje zostały ratyfikowane przez Polskę w $1958 \mathrm{r}$.

${ }^{17}$ Tezy Z I, D 2. 
z władzami szkolnymi oraz z organami samorządu społeczno-gospodarczego. Zakres i kierunki szkolenia miały być ustalane na podstawie zgłaszanego corocznie zapotrzebowania (liczby wolnych miejsc nauki), korygowanego jednak pod kątem potrzeb wynikających z planów przebudowy struktury zawodowej ludności zharmonizowanych z ogólnymi planami społeczno-gospodarczymi. Na młodocianych miał ciążyć obowiązek korzystania z usług stopniowo rozbudowywanego poradnictwa zawodowego, co nie ograniczało jednak swobody wyboru zawodu i miejsca nauki.

Zasadą miało być ustalanie minimalnego odsetka uczniów szkolonych w poszczególnych przedsiębiorstwach w stosunku do liczby pracowników dorosłych, w przeciwieństwie do praktyki z okresu międzywojennego, gdy określano odsetek maksymalny, w obawie przed nadmiernym korzystaniem z pracy uczniów jako tanich pracowników pod formą nauki zawodu. Zatrudnienie młodocianych na podstawie umowy o pracę miało być dopuszczone tylko wyjątkowo, w przypadkach prawem określonych ${ }^{18}$. Prace programowe dotyczące nauki zawodu i poradnictwa zawodowego $\mathrm{w}$ stosunku do młodzieży były prowadzone równolegle w Departamencie Oświaty Delegatury Rządu, przy czym zmierzały w podobnym kierunku ${ }^{19}$.

Uzupełniająco należy wspomnieć, że w Departamencie Pracy była rozważana sprawa wprowadzenia służby pracy dla młodzieży w wieku 17-21 lat: po ukończeniu nauki zawodu lub szkoły średniej ogólnokształcącej, a przed rozpoczęciem studiów wyższych lub służby wojskowej. Służba ta miała polegać na wykonywaniu prac objętych planem inwestycyjnym oraz wychodzących naprzeciw potrzebom społecznym, z tym że została pomyślana przede wszystkim jako akcja wychowawcza ${ }^{20}$. Prace nad tym tematem nie wyszły jednak poza stadium wstępne i nie znalazły odbicia $w$ tezach dotyczących polityki zatrudnienia (w żadnej z ich redakcji).

Jedna jeszcze kwestia, o znaczeniu pozornie tylko techniczno-organizacyjnym, wymaga poruszenia $\mathrm{w}$ ramach ogólnej charakterystyki polityki zatrudnienia. Jest nią postulowane przez Departament wprowadzenie ścisłej ewidencji osób zawodowo-czynnych, prowadzonej przez organy zatrudnienia i samorządu społeczno-gospodarczego, a w szczególności powszechnego obowiązku posiadania dowodów pracy zawierających dane o kwalifikacjach zawodowych i przebiegu

${ }^{18}$ Stanowisko Departamentu w tych sprawach zostało wyrażone nie tylko w tezach ZP II, 24 i Z I, 7-12, lecz także w notatce pt. Uzasadnienie dekretu o pracy młodocianych (maszynopis, s. 2, zbiory W.S.). Tekst projektu tego dekretu się nie zachował.

${ }^{19}$ Zob. Projekt ustawy o obowiazkowym ksztatceniu zawodowym i poradnictwie zawodowym oraz poprawki do tego projektu (maszynopis, s. 6, zbiory rodziny M. Święcickiego).

${ }^{20}$ Tezy w sprawie stużby pracy (redakcja wstępna), (maszynopis, s. 1, zbiory W.S.). Idea tej służby różniła się zasadniczo od ośrodków pracy dla młodzieży prowadzonych w latach trzydziestych przez Stowarzyszenie Opieki nad Niezatrudnioną Młodzieżą (SOM) i przez Fundusz Pracy. Zob. Polityka Spoleczna..., s. 180, a także Fundusz Pracy w latach 1933-1934, Warszawa 1934, s. 34-35. 
pracy $^{21}$. Koncepcja ta wynikała z postulowanych przez Departament ogólnych założeń przyszłego ustroju pracy. Jeśli bowiem charakter pełnionej pracy miał decydować o pozycji człowieka w społeczeństwie, to wydawało się rzeczą naturalną umożliwienie każdemu obywatelowi legitymowania się wkładem pracy świadczącym o wartościach wnoszonych przezeń na rzecz dobra powszechnego. Dowód pracy nabierał z tego punktu widzenia charakteru dokumentu prestiżowego, dotyczącego spraw szczególnie ważnych, niezależenie od jego roli ewidencyjnej, m.in. ze stanowiska uprawnień ubezpieczeniowych. Warto przy tym zauważyć, że idea posługiwania się dowodami pracy nie zrodziła się dopiero w czasie okupacji. Miała ona swoich zwolenników już w okresie międzywojennym, zwłaszcza w środowisku Instytutu Spraw Społecznych. W tego typu dokumentach widziano nie tylko korzyści techniczno-ewidencyjne, lecz również ogólnospołeczne, ze wskazanych wyżej powodów.

Koncepcja ta miała jednak charakter kontrowersyjny, ze względu na jej formalne podobieństwo do „kart pracy” (Arbeitskarten), wprowadzonych przez okupanta i służących eksploatacji zasobów pracy polskiego społeczeństwa dla celów związanych z prowadzeniem wojny. Należało więc liczyć się z oporami przeciwko zastosowaniu przez władze polskie po wojnie podobnych dokumentów i technik ewidencyjnych, pomimo wszelkich odmienności celów i metod postępowania, które miały być oparte co do zasady na poszanowaniu wolności pracy. Zastrzeżeniom tym dało wyraz Ministerstwo Pracy i Opieki Społecznej Rządu Polskiego w Londynie ${ }^{22}$.

Osobne zagadnienie stanowiło określenie struktury przyszłej administracji pracy. W sprawie tej Departament wypowiedział się w cytowanym już sprawozdaniu za I kwartał 1943 r. oraz załączonych do nich tezach dotyczących polityki zatrudnienia ${ }^{23}$. Administracja zatrudnienia miała stanowić część jednolitej administracji społecznej, obejmującej również sprawy ochrony pracy i płac oraz podporządkowanej Ministerstwu Pracy i Opieki Społecznej. Urzędy zatrudnienia miały tworzyć strukturę trzyinstancyjną, na którą składały się urzędy obwodowe (z możliwością uruchamiania ekspozytur w poszczególnych miejscowościach), urzędy okręgowe i organ nadrzędny: Departament Zatrudnienia w Ministerstwie, nadający ogólny kierunek polityce zatrudnienia w całym kraju i prowadzący niezbędne w tym celu praca studialne, instrukcyjne i programowe. Do zadań urzędów zatrudnienia miało należeć przede wszystkim prowadzenie pośrednictwa pracy i nauki zawodu (łącznie z poradnictwem), a także udzielanie pomocy przejściowo

${ }^{21}$ Tezy ZP II, 19 i 22, a także Z I, 2-4 oraz wzmianka w sprawozdaniu Departamentu (cyt. przypis 5), s. 68 .

${ }^{22}$ W piśmie do Delegata Rządu na Kraj z listopada 1944 r. (AAN, MPiOS, sygn. 12, s. 127-128) prośba o wyjaśnienie motywów wprowadzenia tego dokumentu.

${ }^{23}$ Tezy ZP II, 19-20 w odniesieniu do okresu przejściowego. Wątek ten znalazł szersze rozwinięcie we wcześniejszych tezach Z I, C 1-7. 
bezrobotnym. Społeczne i zarobkowe pośrednictwo pracy miało być dopuszczone posiłkowo, w ograniczonym zakresie, pod ścisłą kontrolą organów państwowych i to dopiero raczej w późniejszym okresie (a nie w latach bezpośrednio powojennych) ${ }^{24}$. Pierwsze stadium organizacyjne miało stanowić ,przejęcie i przystosowanie do nowych zadań" okupacyjnych urzędów pracy, z równoczesną zmianą ich charakteru i metod działania ${ }^{25}$.

Likwidacji miał natomiast ulec Fundusz Pracy, w ramach którego przed wojną prowadzono całokształt walki z bezrobociem. Instytucja tego typu wydawała się w okresie powojennym niepotrzebna ze względu na przewidywane zniknięcie bezrobocia jako zjawiska strukturalnego. Akcja inicjowania robót publicznych miała stać się częścią polityki inwestycyjnej, a akcja pomocy dla bezrobotnych miała być włączona do zadań organów zatrudnienia. Stanowisko Departamentu $\mathrm{w}$ tej kwestii zostało zasygnalizowane krótko w tezach przesłanych do Londynu ${ }^{26}$. $\mathrm{Z}$ wewnętrznych dokumentów Departamentu wynika natomiast, że sprawa ta była przedmiotem dyskusji. Rozważano mianowicie potrzebę zachowania pod nazwą Funduszu Pracy pewnego zakresu robót służących inwestycjom w zakresie służby zdrowia, budowy tanich mieszkań pracowniczych i domów wczasowych oraz gromadzenia na ten cel środków za pomocą opłat o charakterze zbliżonym do stosowanych przed wojną. W tych projektach nie widziano jednak potrzeby tworzenia odrębnego aparatu organizacyjnego dla administrowania Funduszem; zadanie to miało być powierzone bezpośrednio Ministrowi Pracy i Opieki Społecznej ${ }^{27}$.

Osobną kwestię stanowiło określenie zasad pomocy udzielanej bezrobotnym. W pierwszej wersji tez przesłanych do Londynu sprawa ta została potraktowana krótko w formie stwierdzenia, że wymiar zasiłków dla bezrobotnych powinien być uzależniony od stanu rodzinnego bezrobotnych i od miejsca ich pobytu $^{28}$. W drugiej wersji tez materii tej poświęcono więcej uwagi. W okresie przejściowym widziano potrzebę udzielenia bezrobotnym pomocy w szerszym zakresie na zasadach pozaubezpieczeniowych ${ }^{29}$. Natomiast w okresie późniejszym (,normalnym”) miało funkcjonować ubezpieczenie na wypadek bezrobocia, obejmujące na jednolitych zasadach robotników i pracowników umysłowych

${ }^{24}$ Tezy ZP II, 23. Wyłączność państwowego pośrednictwa pracy podkreślono $\mathrm{w}$ tezach Z I, D 13.

${ }^{25}$ Ministerstwo Pracy w Londynie kładło nacisk na niezwłoczne powołanie przy tych urzędach „organów doradczych, opiniodawczych i pomocniczych, wyłonionych przez świat pracy, a w szczególności przez związki zawodowe" (w piśmie cytowanym w przypisie 22, s. 2).

${ }^{26}$ Stanowisko to znalazło wyraz tylko w tezach Z I, C 3, natomiast pominięto je milczeniem w tezach ZP II.

${ }^{27}$ Zachowała się w tej materii notatka pt. Uzasadnienie, dotycząca zamierzonego projektu ustawy w kwestii Funduszu Pracy (maszynopis, s. 2, zbiory W.S.). Sam tekst projektu tej ustawy jednak się nie zachował.

${ }^{28}$ Podkreślono przy tym, że zasiłki powinny się należeć wyłącznie osobom, które bez własnej winy nie będą mogły znaleźć pracy (tezy Z I, D 3).

${ }^{29}$ Tezy ZP II, 16c. 
oraz administrowane przez organy zatrudnienia. Wypowiedziano się przy tym za zaostrzeniem rygorów, zabezpieczających przed uchylaniem się od pracy, oraz za udzielaniem w ramach ubezpieczenia zasiłków, umożliwiających odbycie przeszkolenia zawodowego i ułatwiających uzyskanie względnie objęcie pracy ${ }^{30}$.

W Departamencie był przygotowany projekt dekretu o ubezpieczeniu na wypadek bezrobocia. Ubezpieczenie to miało objąć wszystkich pracowników poza rolnictwem, także zatrudnionych w małych zakładach (poniżej pięciu pracowników), które w okresie międzywojennym były wyłączone. W zamian za 2-procentową składkę (dopełnioną przez wpłaty Skarbu Państwa i niektóre opłaty) miało udzielać, w zasadzie przez 4 miesiące, zasiłków wynoszących $40 \%$ (a z dodatkami rodzinnymi $60 \%$ ) pobieranego ostatnio zarobku. Warunkiem nabycia uprawnień zasiłkowych miało być przepracowanie 12 miesięcy w ciągu ostatnich dwóch lat. Wypłata zasiłku miała następować od pierwszego dnia bezrobocia (bez okresu karencyjnego). Z naciskiem podkreślano potrzebę zaostrzenia przepisów wymagających od bezrobotnego podjęcia zaofiarowanej pracy i poddania się proponowanemu przeszkoleniu. Przewidywano w związku z tym przenoszenie bezrobotnych do innych miejscowości i dzielnic kraju ${ }^{31}$.

W całości były to założenia wstępne. Zapowiadały one wyższy niż przed wojną wymiar zasiłków oraz korzystne dla bezrobotnych zniesienie okresu karencyjnego ${ }^{32}$. Przewidywały ubezpieczeniowy charakter systemu zasiłkowego, co świadczyło o traktowaniu bezrobocia jako ryzyka, dającego ująć się w ramy ubezpieczenia i nieprzekraczającego rozmiarów, z którymi należy się liczyć zawsze na rynku pracy. Pozostawało to w zgodzie z ogólnymi przewidywaniami dotyczącymi sytuacji w zakresie zatrudnienia poza okresem przejściowym, wymagającym szczególnych form działania. Prace Departamentu w tej dziedzinie nie wykroczyły poza stadium scharakteryzowanych wyżej założeń. Projekt konkretniejszych rozwiązań prawnych nie został opracowany.

$* * *$

Opracowanie założeń przyszłej polityki płac nasuwało szczególne trudności ze względu na złożoność uwarunkowań. Należały do nich przede wszystkim realia ekonomiczne, o których było wiadomo, że wpłyną ograniczająco na poziom wynagrodzenia, ale równocześnie wymagać będą stwarzania materialnej zachęty do podejmowania prac ciężkich i odpowiedzialnych oraz do pomnażania ich wyników. Ze względów społecznych należało dążyć do zapewnienia powszechnie godziwego minimum i ograniczenia rozpiętości w wymiarze płac, nie można

\footnotetext{
${ }^{30}$ Tezy ZP II, 25, a także 11c.

${ }^{31}$ Notatka o zabezpieczeniu na wypadek bezrobocia (maszynopis, s. 1, zbiory W.S.).

${ }^{32}$ Por. Polityka Społeczna..., s. 146 i n., a także J. Nowacki, Ubezpieczenia na wypadek braku pracy, [w:] Rozwój ubezpieczeń społecznych w Polsce, Warszawa 1991, s. 151 i n.
} 
było jednak akceptować nadmiernego ich spłaszczenia. Trudne dylematy nasuwało też określenie roli podmiotów odpowiedzialnych za prowadzenie polityki płac. $\mathrm{Z}$ jednej strony wydawało się rzeczą naturalną dopuszczenie w szerokim zakresie rokowań i układów zbiorowych, zawieranych przez organizacje pracodawców i związki zawodowe. $Z$ drugiej strony należało obmyśleć mechanizmy służące rozwiązywaniu nieuniknionych konfliktów i respektowaniu założeń wynikających z planowego charakteru gospodarki, co zakładało przyznanie poważniejszych uprawnień organom państwa. Zachodziła więc potrzeba należytego wyważenia roli i wpływów czynnika społecznego (związki zawodowe, samorząd społeczno-gospodarczy) i administracji państwowej, co stanowiło problem par excellence polityczny.

Podobny charakter miał jeszcze jeden aspekt kształtowania wynagrodzeń za pracę. Trudno było bowiem oczekiwać, aby regulacja i poziom płac mogły, co najmniej przez pewien czas po wojnie, zadowalać szerokie kręgi społeczeństwa. Trzeba więc było przewidzieć środki działania pozwalające pogodzić się szerokim rzeszom pracowniczym z trudnymi warunkami życia towarzyszącymi procesowi odbudowy. Polegać to miało najogólniej na umocnieniu pozycji zorganizowanego czynnika pracy i jego wpływu na decyzje określające kierunki polityki społecznogospodarczej. Ten ostatni aspekt sprawy miał kluczowe znaczenie w koncepcjach programowych Departamentu i dlatego został już uwydatniony w rozdziale poprzednim. W odniesieniu do polityki płac nabierał on jednak szczególnej aktualności, co wymaga w tym kontekście ponownego podkreślenia.

W podstawowym dokumencie programowym Departamentu ${ }^{33}$ znalazły wyraz wszystkie wskazane wyżej problemy. Punkt ciężkości padał na podjęcie wielkiego wysiłku produkcyjnego i potęgowanie woli pracy w społeczeństwie przy skromnym z konieczności, zwłaszcza na początku, poziomie wynagrodzeń. Zastrzegano jednak, rzecz znamienna, że hasło tej mobilizacji sił społecznych ,nie może być nadużywane jako uzasadnienie wyzysku pracy lub utrzymywania kosztem pracowników prymitywnych metod lub złej organizacji produkcji”34. Domagano się też „,racjonalizacji kosztów ogólnych przedsiębiorstw poza robocizną”. A równocześnie widziano potrzebę ukształtowania „takiej techniki wymiaru płac, która by premiowała większą sprawność pracy i wynagradzała każdy dodatkowy wkład i wysiłek pracy odpowiednio do jego znaczenia dla usprawnienia produkcji" ${ }^{35}$.

Postulowano ,stopniowe podnoszenie poziomu płac realnych, w ramach możliwości stwarzanych przez wzrost wydajności pracy", wskazując równocześnie na potrzebę „usuwania nieuzasadnionych rozpiętości w poziomie płac

${ }^{33}$ Tezy ZP II, które, jak podkreślono, w części dotyczącej płac pokrywały się niemal całkowicie z tekstem tez P I (co czyni zbędnym odwoływanie się w niniejszym opracowaniu do tamtego tekstu).

${ }^{34}$ Tezy ZP II, 28.

${ }^{35}$ Ibidem, 29 i 31. 
pomiędzy poszczególnymi zawodami, gałęziami produkcji i częściami kraju", a także ograniczenie „nadmiernych wynagrodzeń na wysokich stanowiskach kierowniczych we wszelkiego rodzaju przedsiębiorstwach i zakładach"36.

Rolę podmiotów powołanych do kształtowania polityki płac rozstrzygano stwierdzając, że będzie ona „prowadzona przez państwo przy czynnym współudziale obu zainteresowanych stron, tj. pracodawców i pracowników". Tym ostatnim przyznawano „swobodę układania się", ale „w ramach ustalonych wytycznych i norm”. Zakładano bowiem, że „ich harmonijny współudział w prowadzeniu polityki płac” będzie wymagał podporządkowania „wspólnemu programowi, odpowiadającemu zarówno ogólnym celom gospodarczym państwa, jak i dobrze zrozumianemu interesowi obu stron". Z ogólną polityką płac miały być zharmonizowane zasady wymiaru i poziom uposażeń wypłacanych funkcjonariuszom publicznym ${ }^{37}$.

Ukonkretnieniu tych ogólnych zamierzeń służyły w pewnym stopniu tezy dotyczące kolejnych etapów ich urzeczywistnienia: w latach bezpośrednio powojennych i w czasie późniejszym. W pierwszym z tych etapów, a więc w tzw. okresie przejściowym miała nastąpić przede wszystkim odbudowa wartości realnej najniższych płac oraz zapewnienie wszystkim pracownikom niezbędnego minimum egzystencji. Towarzyszyć mu miało radykalne ograniczenie rozpiętości płac, określone jako „daleko idąca niwelacja”. Łagodzeniu szczególnych trudności tego okresu miała służyć pomoc aprowizacyjna, organizowana przez zakłady pracy oraz rozpowszechnienie dodatków rodzinnych do płac ${ }^{38}$.

Zatargi zbiorowe w większych zakładach pracy miały podlegać obowiązkowi zgłoszenia i, w razie nieskuteczności akcji pojednawczej, miały być rozstrzygane $\mathrm{w}$ trybie przymusowego rozjemstwa przez komisarzy do spraw płac, działających przy okręgowych urzędach zatrudnienia. Orzeczenia rozjemcze mogły uzyskiwać, także bez wniosku żadnej ze stron, moc powszechnie obowiązującą. Uposażenia funkcjonariuszy publicznych miały być regulowane w drodze rozporządzeń Rady Ministrów ${ }^{39}$.

„Po opanowaniu chaosu okresu przejściowego i odbudowaniu w zasadzie wartości realnej płac" (a więc w tzw. okresie normalnym) należało liczyć się nadal z płynnością stosunków, towarzyszącą procesowi przebudowy gospodarczej i w związku z tym ze zmiennością stawek płac. Głównym kierunkiem działania miało być jednak dążenie do ,stworzenia zharmonizowanego systemu płac”, w ramach którego zróżnicowanie ich poziomu powinno być sprowadzone do kryteriów rzeczowych $^{40}$. Główna rola w tym procesie miała przypadać organom państwa.

\footnotetext{
${ }^{36}$ Ibidem, 29, 30 i 32.

${ }^{37}$ Ibidem, 32 i 33.

${ }^{38}$ Ibidem, 36 i 38.

${ }^{39}$ Ibidem, 39-40.

${ }^{40}$ Ibidem, 41.
} 
Państwo miało ustalać w drodze wydawania wytycznych zasady wymiaru i gradacji płac oraz ich wzajemne powiązania, które miały obowiązywać pod rygorem nieważności układów i umów z nimi niezgodnych. Rejestracja układów zbiorowych pracy miała być uzależniona od uprzedniego stwierdzenia tej zgodności. Właściwe organy państwowe miały być ponadto wyposażone w prawo uchylania postanowień układów zbiorowych pracy, nieharmonizujących ze zmianami wysokości płac, dokonanymi w pokrewnych lub powiązanych wzajemnie zawodach, co uzasadniało się troską o wspomnianą harmonizację systemu płac, ale ograniczało zakres swobody układowej ${ }^{41}$.

Samorząd społeczno-gospodarczy miał natomiast przejąć od organów państwa prowadzenie akcji pojednawstwa i rozjemstwa w zatargach zbiorowych pracy. Miał on również czuwać nad wprowadzeniem w życie rządowych wytycznych polityki płac oraz rozwijać je $\mathrm{w}$ formie szczegółowych wskazówek i pouczeń. Natomiast zadanie izb pracy, jednego z podstawowych organów samorządu społeczno-gospodarczego, miało polegać na „ujednolicaniu” (i „urzeczowianiu”) działalności związków zawodowych, przez dostarczanie im odpowiednich danych o sytuacji gospodarczej i o kształtowaniu się rynku pracy ${ }^{42}$.

Całość przedstawionych wyżej tez nasuwa problemy wymagające rozważenia. Pierwszy z nich dotyczy kształtowania gradacji (czy też rozpiętości) płac i to nie tylko w okresie przejściowym lat bezpośrednio powojennych, gdy spłaszczenie poziomu płac narzucało się istotnie, jako nieuniknione ze względu na powszechne obniżenie poziomu życia i trudności zaopatrzeniowe. $Z$ treści przedstawionych tez wynikało jednak wyraźne dążenie do miarkowania kształtowania owych rozpiętości także i w późniejszym okresie („normalnym”), pod kątem sprowadzania ich do właściwej miary, dającej się rzeczowo uzasadnić i opartej na społecznie akceptowanych kryteriach.

Wynikało to w znacznej części z przedstawionej już tendencji do oderwania się od automatyzmu gry rynkowej, sprowadzającej pracę do roli towaru. Tłumaczyło się też przeświadczeniem, że relacje między zarobkami osiąganymi w różnych gałęziach pracy i zawodach powinny odpowiadać społecznej wartości wykonywanych prac, a w każdym razie nie powinny pozostawać w wyraźnej niezgodzie z tym kryterium. Pewną rolę mogło również odgrywać przekonanie, że w kraju, który przez dłuższy jeszcze czas nie będzie mógł osiągnąć wyższego stopnia zamożności i w którym znaczna część społeczeństwa będzie musiała żyć na poziomie odpowiadającym skromnemu minimum egzystencji, nie należy dopuszczać do rozpiętości poziomu wynagrodzeń za pracę, w skali mogącej razić poczucie sprawiedliwości społecznej.

Wszystkie te motywy wpłynęły na sformułowanie hasła „obiektywizacji” płac, mającej oznaczać sprowadzenie rozpiętości ich poziomu do spo-

\footnotetext{
${ }^{41}$ Ibidem, 42-44.

42 Ibidem, 45 i 46.
} 
łecznie uzasadnionego, słusznego wymiaru. Oceniając zasadność powyższego hasła, trzeba zdać sobie bliżej sprawę z jego treści i z jego implikacji. Tezy Departamentu zostały sformułowane w sposób ogólny, bez bliższych wyjaśnień, na jakich kryteriach postulowana obiektywizacja płac miałaby się opierać. Doświadczenia wielu krajów pokazują przekonywająco, jak trudno jest określić i konsekwentnie stosować mierniki służące kształtowaniu płac „według pracy”. Różne metody „mierzenia” czy też „wartościowania” pracy okazywały się w ograniczonym stopniu przydatne i nie pozwalały na całkowite wyeliminowanie elementów subiektywnych ${ }^{43}$. Zwłaszcza gdyby odnosić je do porównywania prac wykonywanych $w$ różnych zawodach i gałęziach produkcji. Uzasadnia to pewien sceptycyzm co do możliwości urzeczywistnienia w pełniejszym zakresie postulatu obiektywizacji płac sformułowanego przez Departament. Tym bardziej że nie wskazano kryteriów, według których wartość pracy miałaby być oceniana.

W świetle tych uwag należy uznać, że „obiektywizacja płac” stanowiła raczej określenie kierunku działania i celu, do jakiego należało dążyć, aniżeli postulat nadający się do pełnego urzeczywistnienia w fazie przestawiania gospodarki na normalne tory.

Źródłem trudności było przy tym nie tylko skonkretyzowanie treści tego postulatu, lecz również określenie mechanizmów mających przyczynić się do wprowadzenia go w życie. Swobodna gra sił społecznych, reprezentowanych przez organizacje zawodowe, nie dawała w sposób oczywisty takich możliwości. Narzucała się zatem myśl o potrzebie ujęcia polityki płac w pewne ramy i poddania jej rygorom wynikającym z kierowniczej roli państwa w kształtowaniu zasad gospodarki planowej. Myśl ta znalazła wyraz w przedstawionych wyżej tezach dotyczących podporządkowania treści układów zbiorowych pracy nie tylko prawu, lecz także wytycznym stanowionym przez organy państwa.

Trzeba przy tym zauważyć, że podobne tendencje wystąpiły w innych dokumentach Departamentu dotyczących już nie samej polityki płac, lecz ogólniejszej dziedziny kształtowania zbiorowych stosunków pracy oraz procedur służących rozwiązywaniu sporów zbiorowych ${ }^{44}$. W dokumentach tych, których bliższe omówienie wchodzi w zakres treści następnego rozdziału, przewidziano wprawdzie wzmocnienie pozycji samorządu społeczno-gospodarczego, wyrażające się w upoważnieniu go do podejmowania uchwał stanowiących swego rodzaju akty normatywne. Równocześnie zmierzano jednak do rozszerzenia zakresu obowiązkowego rozjemstwa w zatargach zbiorowych pracy, równoznacznego z ograniczeniem prawa strajku.

\footnotetext{
${ }^{43}$ Por. M. Kabaj, Funkcje wartościowania pracy, [w:] Metody wartościowania pracy, Warszawa 1979, s. 17.

${ }^{44}$ Prawo o zbiorowym prawie pracy (projekt), CA 203/VII-35, t. 2, s. 141-152 oraz notatka: Zbiorowe prawo pracy i rozjemstwo, s. 153-156a.
} 
Jak widać, trudna do skonkretyzowania, obiektywizacja płac miała swoją cenę w postaci ograniczenia swobody układowej i wzmożenia rygorów wynikających z nadrzędnej roli organów państwa. Na tym polegał główny dylemat polityki płac w postaci projektowanej przez Departament. Można było mieć zastrzeżenia przeciwko wchodzeniu na drogę stosowania owych rygorów i dostrzegać możliwość osiągania zbliżonych celów za pomocą środków pośrednich, będących w dyspozycji organów państwa ${ }^{45}$. Można było też kwestionować stawianie przed polityką płac nazbyt ambitnych zadań, polegających na podporządkowaniu jej naczelnej idei, jaką stanowiła postulowana obiektywizacja. Wątpliwości te trzeba rozważać w kontekście warunków czasu, w jakich powstawały opracowania programowe Departamentu. Niektóre aspekty tej sprawy dotyczą nie tylko polityki płac, lecz również polityki zatrudnienia.

$$
* * *
$$

Obie te gałęzie polityki społecznej mają przede wszystkim tę cechę wspólną, że są bezpośrednio uwarunkowane przez realia gospodarcze. Przewidywania w takich dziedzinach są zawsze trudne, a stopień tych trudności wzrastał niepomiernie w okresie toczącej się wojny, w którym były opracowywane plany i projekty organów Polskiego Państwa Podziemnego. Niełatwo też było określić środki działania, odpowiadające przyszłym potrzebom oraz zapewnić optymalny ich dobór i skuteczność. W każdym razie trzeba było liczyć się z potrzebą kojarzenia środków o różnym charakterze oraz harmonizowania działalności różnych podmiotów ponoszących odpowiedzialność za kształtowanie się polityki społecznej i gospodarczej. Obmyślenie racjonalnej strategii działania w tej dziedzinie wymagało sięgnięcia do różnorodnych instrumentów, wśród których prawo mogło odgrywać jedynie rolę pomocniczą. Wymagało tym samym współdziałania osób reprezentujących różną wiedzę fachową i różny zakres doświadczeń. Niezbędna była ku temu współpraca międzyparlamentarna, której nawiązanie w latach okupacji, zwłaszcza w zakresie problemów dotyczących pracy, natrafiało na duże trudności ${ }^{46}$. Nie mogły tu wystarczać, jakkolwiek przynosiły niekiedy cenne spostrzeżenia, opinie wyrażane w konkretnych sprawach przez przedstawicieli głównych ośrodków politycznych. Nie spełniały też oczekiwanej roli dyskusje prowadzone nad przygotowanymi już opracowaniami na forum Komitetu Ekonomicznego Krajowej Rady Ministrów, toczyły się one bowiem głównie wokół uzgadniania kompromisowych sformułowań w kontrowersyjnych sprawach. W tych okolicznościach tym dotkliwiej dawał się we znaki, wspomniany już wyżej, brak dostępu do pełniejszych danych informacyjnych, mogących stanowić podbudowę dla przewidywań na przyszłość.

\footnotetext{
${ }^{45}$ Sugerowało to Ministerstwo Pracy i Opieki Społecznej w Londynie w uwagach do opracowań Departamentu (AAN, MPiOS, sygn. 12, s. 128).

${ }^{46}$ Por. A. Bień, Bóg wyżej, dom dalej, Warszawa 1991, s. 113 i n.
} 
Na treści opracowań programowych Departamentu dotyczących zatrudnienia i płac zaważyła również krytyczna ocena polityki prowadzonej w latach międzywojennych i uwarunkowane tym poszukiwanie nowych rozwiązań, w diametralnie przeciwnym kierunku. Odrzucając układy wolnorynkowe, w których praca stawała się towarem, widziano jedyne panaceum we wzmożonej ingerencji państwa, porządkującej wszystkie zakresy polityki społecznej i gospodarczej. Wynikające stąd zafascynowanie gospodarką planową wyraziło się w przecenianiu jej możliwości $\mathrm{w}$ odniesieniu do dziedzin $\mathrm{z}$ trudem poddających się jej rygorom. Taki charakter miały niektóre zamierzenia dotyczące „planowego kształtowania rynku pracy" i porząadkowania systemu płac, które cechował nadmierny schematyzm i nieliczenie się ze znaczeniem spontanicznych procesów. Sam kierunek działania zasługiwał $\mathrm{w}$ tych sprawach na ogół na akceptację. Natomiast dobór środków i szczegółowych rozwiązań mógł wzbudzać wątpliwości.

Ściśle powiązane z tym tematem było określenie roli czynnika społecznego w kształtowaniu planowej gospodarki. Sam udział tego czynnika uznawany był przez Departament jako niezbędny, aby zapobiec biurokratyzacji i omnipotencji aparatu państwowego. Chodziło jednak o to, aby ustalić charakter tego udziału. Podstawowy dylemat stanowiło dokonanie wyboru (czy też znalezienie równowagi) pomiędzy konstruktywnym współdziałaniem czynnika społecznego z organami państwa a budowaniem ładu społecznego poprzez grę sił reprezentujących sprzeczne interesy.

Spostrzeżenia zawarte $\mathrm{w}$ tym rozdziale, zwłaszcza $\mathrm{w}$ odniesieniu do roli związków zawodowych $\mathrm{w}$ zatargach zbiorowych i w polityce płac, zdają się świadczyć o przywiązywaniu dużej wagi do pierwszej z powyższych alternatyw. Pełniejszej odpowiedzi na to pytanie należy jednak poszukiwać w rozdziale następnym, poświęconym problematyce ustroju pracy. 


\section{Ustrój pracy}

\section{Uwagi wstępne}

Budowa nowego ustroju pracy stanowiła centralne zagadnienie programu opracowywanego przez Departament Pracy i Opieki Społecznej Delegatury Rządu. Przesądzało to o ogólnym kierunku postulowanych przemian, nie określało jednak samo przez się ich charakteru. Poszukiwanie optymalnych rozwiązań w tej materii nasuwało duże trudności oraz budziło zrozumiałe kontrowersje w środowiskach związanych z różnymi sferami wpływów i interesów. Naczelny postulat stanowiło wzmocnienie pozycji zorganizowanego świata pracy i jego wpływu na politykę społeczno-gospodarczą. Należało zatem dążyć do stworzenia silnej jego reprezentacji o szerokich uprawnieniach i możliwościach działania. Trzeba też było zapewnić jej odpowiednie miejsce w strukturach państwa, ponieważ zakładano, że ma ona stanowić przeciwwagę dla dominującej roli aparatu biurokratycznego.

Równocześnie uznawano, że gospodarka kraju ma mieć charakter planowy i rozwijać się w kierunku rozbudowy jej potencjału wytwórczego, kosztem ograniczenia bieżącej konsumpcji. Trzeba więc było osiągnąć społeczne przyzwolenie na taki model gospodarowania, a w szczególności uzyskać dlań poparcie w organizacjach reprezentujących świat pracy, od których oczekiwano zaangażowania się na rzecz polityki miarkującej zaspokajanie bieżących potrzeb, w celu stworzenia lepszych możliwości na przyszłość.

Polityka taka miała szanse akceptacji w pierwszych latach odbudowy ze zniszczeń wojennych, na dalszą metę musiała jednak budzić w świecie pracowniczym opory trudne do przełamania. Trzeba było zatem dążyć do stworzenia mechanizmów kojarzących mobilizowanie postaw współdziałania w budowie nowego ładu społeczno-gospodarczego ze skuteczną obroną bieżących interesów pracowniczych, licząc się przy tym ze zmiennością sytuacji w czasie. W latach bezpośrednio powojennych (a więc w tzw. okresie przejściowym) zgodne współdziałanie wszystkich sił społecznych narzucało się jako bezwzględny imperatyw. W latach późniejszych należało natomiast otworzyć szersze możliwości ścierania 
się sprzecznych interesów i rozwiązywania konfliktów zbiorowych. Oba czynniki: integracji (partycypacji) i kontestacji miały być jednak, jakkolwiek z różnym nasileniem, trwale obecne w przyszłej polityce pracy.

Bliższe określenie roli każdego z tych czynników w różnych okresach oraz skojarzenie ich z zapewnieniem ciągłości rozwoju kraju w ramach gospodarki planowej stwarzało zrozumiałe trudności. Na sprawę tę należało przy tym spojrzeć nie tylko z perspektywy relacji między organizacjami świata pracy i pracodawców (kapitału) oraz organami państwa, lecz również mając na uwadze strukturę wewnętrzną organizacji reprezentujących świat pracy i ich stosunki wzajemne. W skład tej struktury wchodziły bowiem nie tylko związki zawodowe, jakkolwiek stanowiły jej człon podstawowy, którego pozycję należało nie tylko utrzymać, ale nawet znacznie wzmocnić przez zastosowanie odpowiednich rozwiązań prawno-organizacyjnych.

Odrębny człon miała stanowić reprezentacja pracowników zatrudnionych w poszczególnych zakładach pracy, która mogła być wprawdzie budowana w oparciu o struktury związkowe, ale stwarzała wiele problemów, trudnych do rozwiązania w ramach tych struktur, wskutek czego uzyskała w wielu krajach samodzielny charakter. Ku takiemu rozwiązaniu skłaniał się też Departament Pracy i Opieki Społecznej, widząc w zakładowej reprezentacji (radach zakładowych) ważne ogniwo służące ograniczeniu samowładzy pracodawcy i wzmocnieniu pozycji pracowników, jako współgospodarzy zakładów pracy.

Wyraźna odrębność cechowała również w koncepcji Departamentu Pracy i Opieki Społecznej izby pracy, które stanowiły organiczną część samorządu społeczno-gospodarczego o charakterze publicznoprawny. Rola ich miała polegać z jednej strony na wspomaganiu związków zawodowych i przyczynianiu się do podnoszenia poziomu ich działalności, a $z$ drugiej strony - na reprezentowaniu całego świata pracy wobec państwa i oddziaływaniu w tym charakterze na kierunki polityki społeczno-gospodarczej oraz ustawodawstwa.

Postulowany ustrój pracy miał się zatem ostatecznie opierać na trzech filarach, które stanowiły: rady zakładowe, związki zawodowe i izby pracy; wokół tych trzech instytucji skupiały się też prace programowe Departamentu, mające charakter priorytetowy ${ }^{1}$. Sama koncepcja wyeksponowania roli tych trzech instytucji nie była oryginalnym osiągnięciem Departamentu; dojrzewała ona bowiem już pod koniec okresu międzywojennego w pracach Parlamentarnej Grupy Pracy i „Jutra Pracy”, a w czasie okupacji w wypowiedziach programowych „Unii””. Departament nadał jednak tej koncepcji oryginalną treść, określając bliżej charakter i rolę każdego z wymienionych wyżej trzech członów ustroju pracy, a w szczególności: rad zakładowych i izb pracy.

\footnotetext{
${ }^{1}$ Por. rozdział I.

${ }^{2}$ Por. Tezy w sprawie aktualnych zagadnień dotyczacych świata pracy uchwalone na zebraniu plenarnym w dniu 1 X 1936 r., Parlamentarna Grupa Pracy (cytowane dalej jako Tezy). Zob. przypis 54 , rozdział I.
} 
Nietrudno przy tym dostrzec, że koncepcja ta polegała na szczególnym rozdziale ról pomiędzy te trzy instytucje. Związki zawodowe miały pełnić nadal swą naczelną funkcję, tzn. reprezentowania i obrony doraźnych interesów pracowniczych, wchodząc na drogę rokowań i zatargów zbiorowych oraz uczestnicząc $\mathrm{w}$ procedurach pojednawczo-rozjemczych i zawierając układy zbiorowe pracy. Ich główną linię działania miała stanowić nadal kontestacja i gra sił, której zamierzano jedynie nadać bardziej zorganizowane formy, aby zapobiec akcjom dorywczym i nieodpowiedzialnym, zagrażającym destabilizacją stosunków społecznych i podważeniem planowego charakteru gospodarki. Wymagało to „wzmocnienia struktury organizacyjnej" związków zawodowych przez stworzenie warunków do ich konsolidacji oraz „oczyszczenia stosunków międzyzwiązkowych z niezdrowej konkurencji” m.in. drogą „likwidacji efemeryd” podejmujących nieprzemyślane akcje, które mogły przynosić raczej szkodę sprawie pracowniczej, obniżając prestiż ruchu zawodowego ${ }^{3}$.

Domeną działalności rad zakładowych miały być natomiast sprawy leżące poza sferą przeciwstawności interesów i konfliktów pomiędzy światem pracy i kapitału. Ich naczelnym zadaniem miało być optymalne załatwianie spraw będących przedmiotem wspólnego zainteresowania wszystkich czynników składających się na zakład pracy jako pewną produkcyjną całość. Należało do nich przede wszystkim normowanie wewnętrznego życia zakładu pracy pod kątem zarówno usprawnień techniczno-organizacyjnych, jak również zaspokojenia potrzeb i aspiracji załogi. Udział reprezentacji pracowników w radach zakładowych miał służyć podniesieniu ich do roli współgospodarzy i ograniczeniu sfery arbitralnych decyzji pracodawcy. Same rady miały natomiast stanowić forum wspólnych dyskusji i ustaleń, co wymagało włączenia do ich składu wszystkich czynników działających w zakładzie pracy, zarówno pełniących funkcje wykonawcze na różnych szczeblach, jak i kierownicze, łącznie z kierownictwem naczelnym. Przesądzało to z kolei o składzie rad zakładowych, które miały być instytucją o charakterze mieszanym, a nie formą przedstawicielstwa załogi (co starano się też uwydatnić w ich nazwie: rady zakładowe, a nie załogowe) $)^{4}$.

Gwarancją prawidłowego funkcjonowania rad miały być przepisy prawa określające ich strukturę, zakres i formy działania, skład osobowy i inne. Zakładano jednak z góry, że będą one miały charakter ramowy, unikając nadmiernego formalizowania różnych przejawów aktywności rad, która powinna rozwijać się na bazie obowiązujących przepisów samorzutnie, przybierając coraz bogatsze formy i wypełniając coraz obfitszą treścią klauzule ustawowe. W toku działalności rad zakładowych mogły oczywiście powstawać sprawy sporne, które powinny być

${ }^{3}$ Sprawozdanie z działalności Departamentu Pracy i Opieki Społecznej za I kwartał 1944, s. 2-3 (AAN, KC PZPR 202/I-34, t. 1, k. 66 i n.).

${ }^{4}$ Ibidem, s. 2. 
rozwiązywane na drodze dyskusji i mobilizowania opinii społecznej, bez formalnego odwoływania się do organów funkcjonujących poza społecznością zakładową.

Działalność rad miała bowiem zamykać się bez reszty w ramach zakładu pracy, bez jakichkolwiek odniesień na zewnątrz oraz bez powoływania do życia struktur nadrzędnych, stanowiących nadbudowę hierarchiczną nad radami zakładowymi. Dlatego też z pola działania rad miało być wyłączone wszczynanie zatargów zbiorowych i podejmowanie jakichkolwiek akcji mających na celu wymuszenie określonych ustępstw ze strony pracodawcy. Sprawy tego typu miały bowiem, zgodnie z przyjętym założeniem, być załatwiane i rozwiązywane poza lub ponad zakładem pracy przez związki zawodowes.

Całkowita odrębność charakteru i zadań obu instytucji, a więc związków zawodowych z jednej strony, a rad zakładowych z drugiej, wykluczała bezpośrednie powiązania prawno-organizacyjne między nimi. Nie wyłączała natomiast styczności i wzajemnych oddziaływań faktycznych, ze względu na obecność struktur bądź przedstawicieli związkowych w zakładach pracy i ich zrozumiałe zainteresowanie wszelkimi sprawami dotyczącymi sytuacji pracowników.

Trzeci człon postulowanego ustroju pracy: izby pracy były pomyślane jako instytucje o najszerszym zakresie oddziaływania, obejmującym całe państwo (z ewentualną rozbudową instancji o charakterze regionalnym). Powołanie ich miało być „wyrazem tendencji do scalenia świata pracy w jedną całość prawną, społeczną i gospodarczą, wwiązaną w państwo", co podkreślało unifikacyjny oraz publicznoprawny charakter tej instytucji oraz świadczyło o rozległym zakresie jej zadań. Potwierdzają to dalsze sformułowania programowe, z których wynika, że izby pracy miały być „narzędziem czynnego kształtowania życia zbiorowego” (co świadczyło pośrednio o zamierzonym oddziaływaniu na sferę aktywności związków zawodowych), a także „kontrolowania całokształtu gospodarki społecznej” (co zakładało z kolei wpływ na politykę państwa w tym zakresie) i wreszcie miały „formułować wspólny nadrzędny interes wszystkich warstw pracujących i warstw do nich najbardziej zbliżonych" (co ustawiało izby pracy w pozycji naczelnego przedstawiciela interesów pracowniczych, formułującego niejako syntezę postulatów wysuwanych w różnych branżach i profesjach przez związki zawodowe i inne pokrewne organizacje).

Szczególny charakter izb pracy polegał jednak na tym, że miały one stanowić organiczną część większej całości: samorządu społeczno-gospodarczego, w skład którego miały również wchodzić izby reprezentujące inne warstwy społeczne i kręgi interesów. Każda z nich miała swój zakres działania, w sumie miały jednak składać się na społeczny organ przedstawicielski, przejmujący szeroką dziedzinę zadań publicznych i ograniczający w ten sposób sferę bezpośredniej ingerencji organów administracji państwowej. Stwarzało to pewną paralelę pomiędzy

\footnotetext{
${ }^{5}$ Ibidem.

${ }^{6}$ Ibidem, s. 3.
} 
samorządem społeczno-gospodarczym a radami zakładowymi, które jednoczyły również nie samą tylko załogę pracowniczą, lecz wszystkie czynniki uczestniczące w procesie produkcji, zmierzając do optymalizacji form i efektów ich wspóldziałania. $Z$ tego względu można było w radach zakładowych widzieć podstawowe ogniwo samorządu społeczno-gospodarczego, czy też jego odpowiednik „na dole" w zakładach pracy?.

Wspólną cechę rad zakładowych i izb pracy stanowił fakt, że nie istniały one w Polsce w okresie międzywojennym, trzeba je było zatem tworzyć od nowa zgodnie z założeniami postulowanego ustroju pracy. Zakładowe organy przedstawicielskie działały u nas przed wojną jedynie na Górnym Śląsku, na podstawie przejętego ustawodawstwa niemieckiego, które nadawało im zupełnie odmienny charakter ${ }^{8}$. Na pozostałym obszarze kraju istniały tylko delegacje pracownicze, powołane do załatwiania określonych spraw (np. ustalania list urlopowych) bądź też tworzone zwyczajowo na mocy układów zbiorowych pracy czy też w toku akcji strajkowych. Na krótko przed wojną został opracowany projekt ustawy o radach pracowniczych, który nie wszedł w ogóle pod obrady Sejmu?.

Sprawa izb pracy przedstawiała się o tyle odmiennie, że utworzenie ich zostało przewidziane przez konstytucję marcową z 1921 r., której przepis pozostał jednak w tym zakresie martwą literą, jakkolwiek doszło do powołania innych organów samorządu określanego wtedy jako gospodarczy, a mianowicie izb przemysłowo-handlowych, rzemieślniczych i rolniczych. Sprawa ta stała się przedmiotem wielu komentarzy i polemik, w których z jednej strony oceniano brak izb pracy jako osłabienie reprezentacji interesów pracowniczych wobec państwa, a z drugiej strony wyrażano obawy przed zdominowaniem przez izby ruchu zawodowego. Te ostatnie głosy nasiliły się w końcowych latach okresu międzywojennego w związku z przygotowywaniem projektów ustawowych, zmierzających do wzmocnienia autorytatywnych form rządzenia ${ }^{10}$. Sprawom tym wypadnie poświęcić bliższą uwagę $\mathrm{w}$ toku dalszych rozważań.

Włączenie izb pracy do samorządu społeczno-gospodarczego wymagało, zarówno przed wojną, jak i w toku okupacyjnych prac programowych, spojrzenia na nie z szerszej perspektywy, wykraczającej poza społeczno-prawną problematykę pracy. Stanowiło to, zwłaszcza w toku prac okupacyjnych, dużą trudność, ponieważ zakładało potrzebę ukształtowania ogólniejszej linii programowej Delegatury Rządu. Departament Pracy i Opieki Społecznej nie był wyłącznym czy też głównym gospodarzem w tym wszystkim, co wykraczało poza same izby pracy, a jak

${ }^{7}$ Znalazło to wyraz w treści Rozporządzenia KRM o radach zakładowych z 1 VIII 1944, art. 1.

${ }^{8}$ Ustawa z 4 II 1920 o radach załogowych, „Dziennik Ustaw Rzeszy Niemieckiej” 1920, s. 147 .

${ }_{9}^{9}$ J.G. Wengierow, Przedstawicielstwo pracownicze a państwo, Warszawa 1935, s. 102 i n.; L. Brodowski, Samorzą rad zakładowych, Częstochowa 1947, s. 11-21.

${ }^{10}$ M. Święcicki, Instytucje polskiego prawa pracy w latach 1918-1939, Warszawa 1960, s. 318-324. 
już zaznaczono, problematyki tych izb nie można było oddzielić od szerszej wizji, określającej rolę czynnika samorządowego w gospodarce. Departament nie mógł jednak pozostawić tych aspektów sprawy poza swoim polem widzenia, z tym że jego postulaty, wykraczające poza sferę działania samych izb pracy, nacechowane były z konieczności mniejszą konkretnością. Pełniejsze ich opracowanie wymagało współdziałania departamentów reprezentujących inne resorty (szczególnie przemysłu i handlu oraz odbudowy), a przede wszystkim zaangażowania się kierownictwa Delegatury Rządu na rzecz umocnienia roli samorządu w gospodarce. Zainteresowanie tą linią programową nie znajdowało jednak niestety w pracach Delegatury pełniejszego wyrazu, na skutek czego ten ważny aspekt ustroju gospodarki pozostał do końca bliżej nieopracowany.

Na gruncie problematyki stanowiącej właściwą domenę resortu pracy zarysował się jeszcze jeden ważny problem. Polegał on na określeniu nie tylko pozycji wszystkich trzech omówionych wyżej członów ustroju pracy wobec sfer gospodarczych i organów państwa, lecz także ich wzajemnych stosunków między sobą. $\mathrm{W}$ tej ostatniej dziedzinie powstawały bowiem trudności, od których przezwyciężenia zależało urzeczywistnienie ogólniejszych założeń programowych, przyświecających wizji przyszłego ustroju pracy. Trudności te dotyczyły zwłaszcza relacji między związkami zawodowymi, z jednej strony, a radami zakładowymi i izbami pracy $-z$ drugiej.

Stosunki wzajemne rad zakładowych i związków zawodowych nasuwały zawsze problemy tam, gdzie rady uzyskiwały status odrębnego organu zakładowego i to także wówczas, gdy składały się wyłącznie z przedstawicieli pracowników i miały reprezentować załogę wobec pracodawcy. Tak było w szczególności w Niemczech Weimarskich, gdzie rady zakładowe (Betriebsräte) miały pozycję niezależną od związków zawodowych i własny, im właściwy zakres zadań ${ }^{11}$. Tym bardziej rozwiązanie takie narzucało się w sytuacji, gdy rady miały jednoczyć w swym składzie kierownictwo zakładu i załogę oraz organizować ich współdziałanie. W tym stanie rzeczy niezależność rad od związków zawodowych wydawała się oczywistym postulatem.

Z drugiej strony związki nie mogły i nie chciały pozostawać obojętne wobec żadnych spraw lokalnych, dotyczących pracowników, tym bardziej że właśnie na poziomie lokalnym, w zakładach pracy kształtowały się stosunki i układy, mające duży wpływ na pozycję świata pracy i na autorytet oraz możliwości działania związków zawodowych. Należało tym samym poszukiwać rozwiązań zaznaczających obecność związków w płaszczyznach stycznych krzyżowania się wpływu obu instytucji, które pomimo wszelkich odrębności miały stanowić podstawowe

${ }^{11}$ Por. A. Hueck, H.C. Nipperdey, Lehrbuch des Arbeitsrechts, Mannheim, Berlin, Leipzig 1930, t. II, s. 464 oraz W. Däubler, Das Arbeitsrecht, Reinbek bei Hamburg 1976, s. 184, a także M. Święcicki, Rady zakładowe jako organy ruchu zawodowego, „Państwo i Prawo” 1940, nr 9/10, s. $24 \mathrm{in}$. 
ogniwa ustroju pracy. Postulat ten nabierał pełnej aktualności na gruncie tego modelu rad zakładowych, jaki zdecydowano się wprowadzić u nas po wojnie.

Ważne problemy dotyczyły również stosunków i powiązań pomiędzy ruchem zawodowym a izbami pracy. Wynikały one z zawieszenia izb pomiędzy organizacjami świata pracy a organami państwa oraz z ich publicznoprawnego charakteru, wyposażającego je w kompetencje do działania w imieniu ogółu pracowników. Bliższe określenie charakteru i zadań izb pracy nabierało tym samym niezwykle ważnego znaczenia. W zależności od przyjętych w tym zakresie rozwiązań izby pracy mogły stać się bądź emanacją ruchu zawodowego, służącą umocnieniu jego pozycji, bądź też instancją nadrzędną, koordynującą jego działalność. O takim lub innym charakterze izb pracy musiał przy tym decydować kompleks przepisów, które regulując sposób powoływania izb pracy, ich skład oraz wewnętrzną organizację, jak tryb postępowania, w sumie kształtowały model tych izb i przesądzały o ich roli i kompetencjach. We wszystkich tych sprawach, które w okresie międzywojennym budziły wiele kontrowersji, należało zająć konsekwentne stanowisko, nadające izbom pracy czytelny charakter, zgodny z ogólnymi założeniami postulowanego ustroju pracy ${ }^{12}$. Nie trzeba przy tym dodawać, że były to sprawy, wokół których skupiało się szczególne zainteresowanie konspiracyjnych organów partii politycznych i ruchu zawodowego. Wymagały więc one, bardziej niż inne aspekty ustroju pracy, dokonywania odpowiednich konsultacji i uzgodnień.

Problematyka ustroju pracy kryła w sobie, jak widać, wiele trudnych problemów, od których rozwiązania zależało oblicze całego programu społecznogospodarczego Delegatury Rządu. W Departamencie Pracy i Opieki Społecznej prace te skupiły na sobie szczególną uwagę, pomimo to nie wszystkie ich wątki zostały jednakowo zaawansowane i nie wszystkie zostały doprowadzone do fazy końcowych podsumowań i dojrzałych projektów legislacyjnych.

Najpełniejszy efekt przyniosły prace dotyczące przyszłego kształtu rad zakładowych. Wyraził się on w przygotowaniu aktu prawnego, który po konsultacjach i wewnętrznych dyskusjach w Delegaturze został zaakceptowany przez Krajową Radę Ministrów i opublikowany w „Dzienniku Ustaw” w czasie powstania warszawskiego $^{13}$. W tym zakresie mamy zatem do czynienia z aktem oficjalnym, wyrażającym ostateczne stanowisko Delegatury Rządu, niezależnie od materiałów przygotowawczych, mających w tej sytuacji wtórne znaczenie, pomocne w jego interpretacji ${ }^{14}$. O skupieniu największej uwagi na tym akcie rozstrzygnęło przeko-

${ }^{12}$ Por. M. Święcicki, Instytucje..., s. 320 i n.

${ }^{13}$ Rozporzadzenie KRM z 1 VIII 1944 o radach zakładowych, Dz. U. RP, cz. III, 2 VIII 1944, nr 2, poz. 16.

${ }^{14}$ Do materiałów tych należą: (1) Sprawozdanie Departamentu za I kwartat 1944 (por. przypis 3 ) oraz załączone do niego (2) tezy pt. Rady Zakładowe, a także (3) Uzasadnienie projektu dekretu Prezydenta Rzeczypospolitej: Prawo rad zakładowych w dwóch wersjach: krótszej, ograniczonej do części ogólnej (4 strony), i pełnej, odnoszącej się do całego tekstu (stron 29), z tym że obie wersje mają 
nanie o szczególnej pilności uregulowania stosunków w zakładach pracy zgodnie z nowymi założeniami programowymi, tak aby nowa regulacja prawna zaczęła obowiązywać z możliwie najmniejszym opóźnieniem w stosunku do daty ich przejęcia z rąk okupanta i uruchomienia po działaniach wojennych.

Znacznie mniej zaawansowane zostały prace nad dwoma pozostałymi trzonami ustroju pracy, a mianowicie nad związkami zawodowymi i izbami pracy. W tym zakresie dysponujemy, poza tezami programowymi, kilkoma tekstami projektów wewnętrznych Departamentu Pracy i Opieki Społecznej, z których żaden nie uzyskał akceptacji kierownictwa Delegatury, a nawet trudno ustalić, który z nich wyrażał ostateczne stanowisko Departamentu. Pomimo to, składają się one w całości na obraz prac legislacyjnych przepojonych jedną wyraźną myślą programową. Jest to obraz czytelny, jakkolwiek nierównomiernie dopracowany w szczegółach i niewyjaśniający do końca wszystkich kwestii kontrowersyjnych.

Okoliczności te trzeba mieć na uwadze, przystępując do analizy tego materiału. Wymagają one pewnej ostrożności w formułowaniu wniosków i ocen. Nie stoją jednak na przeszkodzie podjęciu próby opracowania go w całości i odczytania przyświecających mu idei przewodnich. Kolejne części tego rozdziału będą poświęcone radom zakładowym, związkom zawodowym i izbom pracy, a podsumowanie całości wywodów i końcowe wnioski złożą się na treść punktu 5.

\section{Rady zakładowe}

Zgodnie z przedstawioną koncepcją rady zakładowe zostały pomyślane nie jako organ reprezentujący interesy załogi w stosunku do pracodawcy, lecz jako instytucja organizująca współdziałanie całej społeczności zakładowej w dążeniu do osiągnięcia wspólnych celów. Nie oznaczało to przechodzenia do porządku nad sprzecznościami interesów między światem pracy i kapitału oraz koniecznością zapewnienia skutecznej obrony klasowych interesów pracowniczych. Rolę tę miały bowiem, jak już wyjaśniono, spełniać związki zawodowe, rozwijające swą działalność w szerszej skali różnych branż i profesji.

Na szczeblu zakładów pracy uznano natomiast za celowe tworzenie form organizacyjnych, sprzyjających budowaniu konstruktywnej współpracy. Formy te miały zapewnić pracownikom udział w rozstrzyganiu spraw wspólnie ich interesujących oraz położyć kres „samowładztwu” pracodawcy (kierownika) ${ }^{15}$. W związ$\mathrm{ku} \mathrm{z}$ tym postulowano, aby regulamin pracy nabrał charakteru „konstytucji

odniesienia do projektu, a nie do ostatecznego tekstu dekretu (stąd różnice w numeracji artykułów). Treść tego aktu nie uległa jednak w końcowym opracowaniu poważniejszym zmianom. Oba teksty przechowano w zbiorach rodziny Macieja Święcickiego. Cytowane dalej jako Uzasadnienie dotyczy rozszerzonej wersji. W przypadkach odwoływania się do wersji skróconej zaznaczono to wyraźnie.

${ }^{15}$ Por. notatka Ustrój pracy w materiałach Departamentu (zbiory W.S.), s. 1-2. 
zakładowej"16 oraz aby sprawy dotyczące całej załogi były przekazywane do rozpatrzenia radzie zakładowej, a w pewnych przypadkach poddawane jej decyzji. Miało to utorować drogę do rzeczywistego współdziałania kierownictwa zakładów pracy z załogami w sprawach pracowniczych i socjalnych, a niekiedy także technicznych i produkcyjnych. W tym sensie rady zakładowe miały stanowić ,narzędzie przystosowania ustroju wewnętrznego zakładu pracy do potrzeb przebudowy ustroju społeczno-gospodarczego"17 w ogólnym wymiarze.

Zmierzając w tym kierunku, wychodzono z założenia, że sytuacji człowieka w zakładzie nie wyczerpuje treść umowy o pracę oraz że „nie wystarczy skierować odpowiednich ludzi do odpowiednich czynności i wpleść ich we wspólny z narzędziami martwymi łańcuch produkcyjny"18, aby zapewnić pożądane efekty pracy zespołowej. Za punkt wyjścia w porządkowaniu stosunków ludzkich w zakładach pracy należało bowiem uznać zbiorowość, ożywioną gotowością współdziałania oraz świadomą łączących ją więzi społecznych, tak aby zakład pracy stanowił organiczną całość nie tylko w sensie technicznym, ale także ludzkim.

Pomyślana w ten sposób rada zakładowa miała być, w odróżnieniu od niemieckiego modelu rad zakładowych działających przed wojną na Górnym Śląsku, organem całości, przedstawicielstwem czynnika ludzkiego w zakładach pracy ${ }^{19}$, a nie jednostronnym przedstawicielstwem pracowniczym, miała ją też cechować wewnętrzna jedność, bez podziału na przedstawicieli robotników i pracowników umysłowych, który był stosowany w tamtych radach ${ }^{20}$. Koncepcja ta zbliżała się natomiast do przyjętego po wojnie we Francji modelu komitetów, jednoczących w swym składzie załogę i szefa przedsiębiorstwa (comités d'entreprise) ${ }^{21}$.

Warto przy tym podkreślić, że w projektowanym unormowaniu rad zakładowych odchodzono świadomie od innych koncepcji ukształtowanych w niemieckiej nauce prawa pracy. Nie posługiwano się w szczególności pojęciem dbałości o załogę oraz obowiązku wierności z jej strony, wychodzono bowiem z założenia, że obowiązki dbałości i wierności występują w różnych układach i nie zawsze są przeciwstawne, a ponadto nie wyczerpują treści stosunków wzajemnych między załogą i kierownictwem, i w związku z tym nie powinny być nadmiernie akcentowane ${ }^{22}$.

Nie eksponowano również jako naczelnego celu projektowanych form ustrojowych zakładu pracy jako tzw. pokoju społecznego, stwierdzając, że jest on

${ }^{16}$ Ibidem, s. 2.

${ }^{17}$ Wstęp do rozporządzenia o radach zakładowych (por. przypis 14).

${ }^{18}$ Uzasadnienie, s. 2.

${ }^{19}$ Ibidem, s. 4.

${ }^{20}$ Nie trzeba przy tym podkreślać, że cechowała ją całkowita przeciwstawność do koncepcji rad zakładowych przyjętej w reżimie hitlerowskim, wprowadzonym w czasie wojny na terenie „ziem wcielonych” do Rzeszy. W systemie tym rady zakładowe zostały sprowadzone do roli Beiratu, przydanemu do pomocy Fuhrerowi postawionemu na czele zakładu pracy.

${ }^{21}$ Por. A. Brun, H. Galland, Droit du Travail, Paris 1978, t. II, s. 222 i n.

${ }^{22}$ Uzasadnienie, s. 5. 
wprawdzie w szerokim zakresie pożądany, ale nie stanowi „najwyższej wartości”. Nie chodzi bowiem o to, aby zapewnić „, mechaniczny bieg” bez tarć, pod którego przykrywką gromadziłyby się wówczas „nierozładowane siły”23. Za myśl przewodnią przyjęto, aby „trudności służyły rozwojowi, aby z przeciwstawności powstawała doskonalsza jedność" ${ }^{24}$. Instytucja rad zakładowych miała w założeniu proces ten ułatwić i odpowiednio go ukierunkować.

U podstaw tych rozwiązań leżała koncepcja zakładu pracy jako instytucji skupiającej w jedną całość grupę ludzi i zasoby materialne, trwającej niezależnie od zmian w składzie osób z nią związanych. Akcentowała ona mocno istnienie zakładu pracy jako odrębnej jednostki organizującej stosunku pracy, bliska była uznania go za odrębny podmiot prawa obok pracodawcy i pracowników ${ }^{25}$.

Scharakteryzowane założenia znalazły wyraz w art. 1 dekretu o radach zakładowych z 1 VIII 1944 r., któremu zostało nadane następujące brzmienie: „Rady zakładowe są wyrazem i narzędziem przystosowania ustroju wewnętrznego zakładu pracy do potrzeb ustroju społeczno-gospodarczego. Jednoczą one obsadę (kierownika i załogę) zakładu, umacniają w niej zrozumienie jego zadań społeczno-gospodarczych i wolę wspólnego wysiłku w ich spełnianiu".

Rady zakładowe powołane do tych zadań miały mieć charakter powszechny, tzn. miały działać we wszystkich zakładach pracy ${ }^{26}$, bez względu na ich charakter prawny. „Gdziekolwiek wykonywana jest zorganizowana praca - czytamy w uzasadnieniu - wszędzie potrzeba wiązadeł zespalających czynnik ludzki. Nie ma podstawy, aby od tej zasady odstępować w stosunku do tych zakładów pracy, w których praca ma charakter służby publicznej”27. Przewidziana została jednak możliwość zastosowania w tych zakładach (urzędach) odrębnych unormowań, odpowiednio do ich charakteru ${ }^{28}$.

Istotnym kryterium była natomiast wielkość zakładu pracy, a ściślej biorąc liczebność jego załogi. Rady miały być tworzone w zakładach zatrudniających ponad 19 osób (w zakładach mniejszych o personelu od 5 do 19 osób miał być natomiast powoływany mąż zaufania). Poszczególne przedsiębiorstwa mogły stanowić jeden zakład pracy bądź też mogło być wyodrębnione w nich więcej

${ }^{23}$ Ibidem, s. 6. Trzeba natomiast zauważyć, że w Tezach wyeksponowane zostało „stworzenie w zakładach pracy właściwych podstaw pokoju społecznego" (teza 1). Nie znalazło to jednak potwierdzenia w tekście dokumentu.

${ }^{24}$ Ibidem.

${ }^{25}$ Ibidem, s. 1. Koncepcja podmiotowości zakładu pracy została podtrzymana przez M. Święcickiego w jego powojennej publikacji: Prawo stosunku pracy, Częstochowa 1949, s. 29 i n. W późniejszych opracowaniach jednak od niej odstąpił.

${ }^{26} \mathrm{Z}$ wyłączeniem gospodarstw rolnych, leśnych i ogrodniczych (art. 4).

${ }^{27}$ Uzasadnienie, s. 7.

${ }^{28}$ Zgodnie z art. 44 dekretu Rada Ministrów została upoważniona do określenia w drodze rozporządzenia terminu, zakresu i sposobu zastosowania jego przepisów do urzędów państwowych i samorządowych. 
zakładów, stanowiących osobne jednostki organizacyjne i mających własne rady zakładowe. Decyzja w tej sprawie miała należeć do właściwego organu administracji pracy (art. 2 ust. 3 dekretu).

Zgodnie z przedstawionymi wyżej założeniami dekret głosił, że ,rada zakładowa składa się z kierownika zakładu pracy i z wybranych przez załogę radnych zakładowych" (art. 19). Za kierownika zakładu należało uważać tego, kto „prowadzi zakład pracy i zarządza nim” (art. 20 ust. 2). Decydował zatem sam charakter faktycznie pełnionej funkcji, a nie tytuł jej sprawowania, którym mogło być zarówno prawo własności, jak i nominacja, umowa czy wybór ${ }^{29}$. Zapewnieniu rzeczywistego współdziałania miał przy tym służyć wymóg, aby kierownik zakładu pracy osobiście uczestniczył w pracach rady zakładowej ${ }^{30}$. Jedynie „w razie bezwzględnej niemożliwości przybycia na zebranie" (przykładowo podano chorobę, doraźny urlop) mógł on w konkretnym przypadku wyznaczyć swego zastępcę (art. 33 ust. 2).

Ze stanowiskiem kierownika zakładu nie zostało natomiast powiązane automatycznie przewodnictwo $\mathrm{w}$ radzie zakładowej. O wyborze przewodniczącego miała bowiem decydować sama rada w głosowaniu tajnym. Nie wyłączało to wyboru kierownika, co w praktyce mogło wydawać się naturalne. Jednakże w razie zmiany na stanowisku kierownika wybór ten nie przechodził na następcę. W mniejszych zakładach pracy (gdy rada liczyłaby mniej niż 5 członków) wybór kierownika na przewodniczącego rady mógł być dokonany tylko jednomyślnie (art. 29 ust. 2, art. 30, ust. 3). Wyjątek od powyższych zasad, polegający na powierzeniu przewodnictwa w radzie kierownikowi z mocy prawa, został przewidziany w zakładach wymagających szczególnej dyscypliny i karności (jak np. statki morskie), art. 56 ust. $1 \mathrm{~b}^{31}$.

Niezależnie od kwestii przewodniczenia w radzie kierownik zakładu znajdował się jednak w stosunku do niej w sytuacji szczególnej. Przede wszystkim do niego należało zwołanie pierwszego posiedzenia rady w celu dokonania wyboru przewodniczącego (art. 30 ust. 1). Ponadto jego obecność, niezależnie od quorum składu rady, stanowiła warunek ważności posiedzeń rady (art. 33 ust. 1). Jedynie w porozumieniu z nim mogły być też zwoływane zebrania części lub całej załogi dla omawiania spraw uznanych za ważne przez radnych (art. 36 ust. 4). Należało ponadto mieć na uwadze faktyczny wpływ kierownika zakładu na bieg spraw

${ }^{29}$ Uzasadnienie, s. 16. Należy przy tym podkreślić, że dekret mówi konsekwentnie o kierowniku zakładu pracy, odrzucając pojęcie pracodawcy. W tekście dekretu uwydatniono natomiast związek kierownictwa z prawem własności zakładu (art. 20 ust. 3). Zastrzeżono przy tym, że właściciel zakładu pracy nie może ograniczać obowiązków i uprawnień kierownika ani dzielić ich między kilka osób. Śmierć lub zmiana właściciela nie pociągała za sobą wygaśnięcie obowiązków i uprawnień kierownika zakładu (art. 20 ust. 4).

${ }_{30}^{30}$ „Kierownik chodzi do rady osobiście” (art. 20 ust. 1).

${ }^{31}$ Natomiast $w$ prawie francuskim przyjęto, że dyrektor przedsiębiorstwa bądź jego przedstawiciel jest z urzędu przewodniczącym rady (A. Brun, H. Galland, op. cit., s. 231). 
mających związek z działalnością rady, ze względu na charakter zajmowanego przezeń stanowiska.

Przeciwdziałać wynikającym stąd zagrożeniom dla normalnego funkcjonowania rady zakładowej miały sankcje karne, nakładane na kierowników uniemożliwiających odbywanie zebrań rady lub dokonywanie wyboru jej przewodniczącego. Sankcje te obejmowały karę aresztu i grzywny, a w razie recydywy (za trzecim razem) również pozbawienia prawa kierowania zakładem pracy na czas od 6 miesięcy do 3 lat. Warunkiem ich zastosowania było działanie o charakterze umyślnym (art. 45) ${ }^{32}$.

Przechodząc do radnych zakładowych wybieranych przez załogę, należy stwierdzić, że liczba ich miała wynosić, zależnie od wielkości zakładu, od 2 do 18 osób, a w zakładach zatrudniających ponad 3500 pracowników mogła przekraczać tę liczbę (decyzja należała wówczas do samorządu społeczno-gospodarczego, art. 21 ust. 2 i 3). Wybór radnych miał być dokonywany w taki sposób, aby każdy dział pracy (a więc każda grupa pracowników związanych miejscem wykonywania pracy lub jej rodzajem) miał swego reprezentanta. Obok działów mógł być również uwzględniony podział na kategorie pracowników, z tym że w odróżnieniu od rad zakładowych, jakie istniały przed wojną na Górnym Śląsku - nie przewidywano odrębnej reprezentacji robotników i pracowników umysłowych. Ustaleń co do kryteriów wyodrębniania działów i kategorii miał dokonywać właściwy organ administracji pracy, z tym że przewidziana została również możliwość określenia ich w drodze porozumienia załogi (art. 22). Czynne prawo wyborcze miało przysługiwać wszystkim pracownikom powyżej 18 lat, natomiast bierne prawo wyborcze zostało uzależnione od ukończenia 24 lat, dwuletniego stażu pracy w swoim (lub pokrewnym) zawodzie oraz sześciomiesięcznego co najmniej okresu zatrudnienia w danym zakładzie (art. 26 ust. 1 i 2).

Wybory radnych: równe, tajne i bezpośrednie (na konkretne nazwiska), miały być przeprowadzane co dwa lata, przez komisję powoływaną przez ustępujących radnych, a w razie gdyby to było niemożliwe - przez izbę pracy, na wniosek kierownika zakładu. Nadzór nad prawidłowością wyborów miał sprawować sąd pracy, a w jego braku sędzia grodzki. Prawo obecności przy czynnościach komisji miało przysługiwać kierownikowi zakładu pracy lub jego zastępcy oraz przedstawicielom związków zawodowych, obejmujących zakresem swej działalności daną gałąź pracy. Osoby te mogły także, na równi z pracownikami, wnosić sprzeciwy i zażalenia na czynności komisji do sędziego sprawującego nadzór nad prawidłowością wyborów (art. 25).

Radni i członkowie komisji wyborczych mieli pełnić swe obowiązki honorowo, jednakże w razie konieczności wykonywania ich w godzinach pracy należał

\footnotetext{
${ }^{32} \mathrm{O}$ fakcie uniemożliwienia odbycia posiedzenia rady zakładowej wskutek nieobecności kierownika każdy z radnych mógł zawiadomić Izbę Pracy, wnosząc wzmiankę o tym do księgi protokołów rady (art. 33 ust. 3).
} 
im się zwrot utraconego zarobku. Stosunek pracy radnych został objęty ochroną: przeniesienie ich do innego działu pracy mogło nastąpić tylko za ich zgodą, wyrażoną na zebraniu rady; zwolnienie niezwłoczne - tylko z ich winy, a wypowiedzenie umowy - w razie zmniejszenia stanu zatrudnienia $\mathrm{w}$ danym dziale pracy do $1 / 5$ (z prawem ponownego przyjęcia do pracy, gdyby zwiększył się on następnie do 2/5 (art. 38-41).

Zadania rady zakładowej zostały określone następującą formułą: „Rada normuje życie wewnętrzne zakładu, wpływa na kształtowanie się go zgodnie z prawem i dobrymi obyczajami oraz omawia, ocenia i rozstrzyga sprawy zakładowe w zakresie poruczonym jej przez ustawę, zbiorowe prawo pracy (układ zbiorowy pracy, orzeczenie rozjemcze) lub zwyczaj” (art. 5). Ze sformułowania tego wynika, że uprawnienia mające przysługiwać radom zakładowym były niejednolite: co do niektórych spraw mogły one wypowiadać się wiążąco (normuje, rozstrzyga), co do innych głos ich nie miał takiego charakteru (omawia, zaleca).

Wśród spraw należących do pierwszej kategorii największe znaczenie miało stanowienie regulaminu pracy. Do tego uprawnienia przywiązywano szczególną wagę. Chodziło bowiem o zasadniczą zmianę trybu określania wewnętrznego porządku w zakładach pracy, a w szczególności o wyłączenie go ze sfery kompetencji samego pracodawcy. W miejsce jednostronnego aktu kontrolowanego jedynie pod kątem zgodności z prawem, jak to przewidywało prawo okresu międzywojennego, miała wejść uchwała organu reprezentującego całą „obsadę” personalną zakładu pracy, a wśród niej wszystkie działy i kategorie pracowników. Regulamin pracy nie nabierał wprawdzie na tej drodze charakteru aktu dwustronnego, jak to było na gruncie koncepcji rad zakładowych przyjętej w Niemczech Weimarskich ${ }^{33}$. Miał jednak stanowić wynik porozumienia pomiędzy reprezentowanym w składzie rady kierownictwem i zasiadającymi w niej również przedstawicielami załogi ${ }^{34}$.

Taki charakter uchwał rady zakładowej, ustanawiających regulamin pracy, wynikał pośrednio z faktu, że jakkolwiek uchwały te mogły zapadać większością głosów i kierownik zakładu mógł być przegłosowany, to jednak w tym przypadku przysługiwało mu prawo sprzeciwu, rozstrzyganego przez właściwy organ samorządu społeczno-gospodarczego (art. 17 ust. 4) ${ }^{35}$. Ostatecznie zatem

${ }^{33}$ Betriebsvereinbarung. Por. A. Hueck, H.C. Nipperdey, op. cit., s. 315.

${ }^{34} \mathrm{~W}$ Uzasadnieniu określono regulamin pracy jako „prawo autonomiczne społeczności zakładowej” oraz położono nacisk na „równość członków rady przy jego uchwalaniu” (ibidem, s. 21). Uznano też regulamin pracy za „ostatnie ogniwo w łańcuchu norm zbiorowego prawa pracy” (ibidem, s. 9). Natomiast w modelu francuskim rola rady (comité d'entreprise) przy stanowieniu regulaminu ograniczała się do uprzedniej konsultacji (A. Brun, H. Galland, op. cit., s. 262).

${ }^{35} \mathrm{Na}$ kierowniku zakładu ciążył obowiązek przedstawienia pierwszego projektu regulaminu i projektów mających dostosować jego treść do zmian prawa (art. 17 ust. 2). Kierownik został też zobowiązany do ogłoszenia regulaminu przed upływem 3 dni od daty jego uchwalenia bądź zapadnięcia orzeczenia rozstrzygającego zgłoszony sprzeciw; z tą datą regulamin wchodził w życie (art. 17 ust. 5). 
treść regulaminu nie mogła być narzucona kierownikowi pracy wbrew jego woli. Ustanowienie regulaminu nie mogło jednak również nastąpić wbrew stanowisku większości radnych reprezentujących załogę, a ponadto radni uzyskali wpływ na treść regulaminu poprzez możność przedstawiania własnych projektów i propozycji (art. 17 ust. 2). Samo wydanie regulaminu pracy miało być, podobnie jak w przedwojennym porządku prawnym, obligatoryjne we wszystkich większych zakładach pracy ${ }^{36}$. Treść regulaminu miała obejmować poza przepisami porządkowymi ${ }^{37}$ także wykaz kar grożących za naruszenie prawa o radach zakładowych.

Prawo to zawierało obszerny katalog spraw, poza regulaminem pracy, mogących stanowić przedmiot obrad i ewentualnych uchwał rady zakładowej. Należało do nich: ustalenie norm wydajności i premiowania, powiększenie lub zmniejszenie ciężaru stałej pracy przydzielanej pracownikowi bez zmiany wynagrodzenia, stosowanie środków bezpieczeństwa pracy, szkolenie uczniów, polepszanie warunków pobytu pracowników w zakładzie. Rada mogła również ingerować w przypadku wypowiedzenia stosunku pracy pracownikom o dłuższym stażu pracy w danym zakładzie (ponad dwa lata) oraz w razie skurczenia się możliwości zatrudnienia, co stawało na porządku dziennym sprawę takiego rozłożenia pracy, aby jak najmniejsza liczba pracowników całkowicie ją utraciła. W razie powstania takiej sytuacji kierownik został zobowiązany do wniesienia jej pod obrady rady. Do zakresu zadań rady zakładowej należało też wypowiadanie się w sprawie list urlopowych, co miało służyć ich uzgodnieniu w razie wniesienia zastrzeżeń przez kierownika zakładu (art. 7-10).

We wszystkich wymienionych wyżej sprawach rada mogła zajmować stanowisko $\mathrm{w}$ formie uchwał, z tym jednak ważnym zastrzeżeniem, że wiążące były jedynie uchwały podjęte jednomyślnie (a więc takie, za którymi głosował również kierownik zakładu), natomiast uchwały przyjęte większością głosów miały jedynie charakter zaleceń. Te ostatnie nie podlegały obowiązkowemu wykonaniu przez kierownika zakładu. Przewidziano jedynie pośredni środek nacisku, w postaci przedstawienia sprawy właściwemu organowi samorządu społeczno-gospodarczego. Mogło to jednak nastąpić dopiero po trzykrotnym bezskutecznym wydaniu przez radę zalecenia w tej samej sprawie (art. 18 ust. 5) ${ }^{38}$. W niektórych przypadkach fakt rozpatrywania sprawy przez radę mógł pociągać za sobą szczególne skutki (np. odroczenie rozwiązania stosunku pracy, gdy rada zajęła się daną kwestią na wniosek pracownika, o czym niżej).

${ }^{36}$ Należało przez nie rozumieć zakłady zatrudniające ponad 19 pracowników. Nadzór nad zgodnością regulaminu pracy z prawem miał należeć do organów administracji pracy (art. 6 ust. 2).

${ }^{37}$ Szczegółowy ich wykaz podano w art. 6 ust. 3 dekretu.

${ }^{38}$ Zawiadomienie organów samorządu społeczno-gospodarczego nie stanowiło formalnego odwołania, lecz „wyższy i silniejszy stopień ujawnienia sprawy” niż poprzez zapis w protokóle. Zalecenia rady miały działać „tylko ciężarem słuszności wewnętrznej i uzyskanego dzięki niej poparcia czynników pozazakładowych". Nie przewidywano żadnych procedur odwoławczych od decyzji kierownika zakładu (Uzasadnienie, s. 21-22). 
Za jedno z naczelnych zadań rady zakładowej zostało uznane czuwanie nad przestrzeganiem regulaminu pracy i układu zbiorowego pracy (art. 7 ust. 1), a w związku z tym pilne rozpatrywanie wniosków, zażaleń i życzeń załogi, także poza przewidzianym porządkiem obrad (art. 12 ust. 2 i 3). Rada miała też podejmować próby pojednania w zgłoszonych jej sporach indywidualnych, przy czym przewidywano zawieszenie postępowania sądowego do czasu stwierdzenia bezskuteczności takiej próby (art. 12 ust. 1).

Rada zakładowa miała oceniać działalność przyzakładowych i pozazakładowych urządzeń prowadzonych przez zakład dla dobra załogi (takich, jak: domy fabryczne, szpitale, czytelnie, dziecińce, żłobki, organizacje wczasów), a w szczególności miały jej przysługiwać uprawnienia w stosunku do instytucji i urządzeń samopomocowych; podlegały one bowiem nadzorowi i kontroli ze strony rady, która miała również prawo zawieszania władz tych placówek i wyznaczania tymczasowego kierownictwa (art. 11). W tym ostatnim przypadku osobom zainteresowanym służyło prawo wniesienia sprzeciwu do właściwego organu samorządu społeczno-gospodarczego.

Wszystkie omówione sprawy zostały określone jako dotyczące kształtowania wewnętrznego życia zakładu pracy (art. 14 ust. 1). Odróżniano od nich „sprawy kierowania i zarządzania zakładem pracy”, co do których stwierdzono wyraźnie, że nie należą do właściwości rady, chyba że kierownik podda je pod obrady. Równocześnie jednak kierownik został zobowiązany do zapoznawania rady, przynajmniej raz do roku, z wynikami działalności zakładu, ze szczególnym uwzględnieniem wykonania zadań produkcyjnych (art. 13).

Przedstawione kompetencje rady zakładowej mogą dzisiaj wydawać się skromne i nie dość przekonywające, trzeba jednak mieć na uwadze warunki, w jakich regulacja ta dochodziła do skutku. Postulując ograniczony charakter zmian ustrojowych oraz licząc się z tym, że aparat wytwórczy pozostanie w przeważającej części w prywatnym władaniu, należało poszukiwać takich rozwiązań, jakie mogły w tym systemie być akceptowane i okazać się operatywne. Tym bardziej że ośrodki myśli zachowawczej w samej Delegaturze przeciwstawiały się śmielszym koncepcjom reformy społecznej i odnosiły się krytycznie do samej instytucji rad zakładowych, podobnie zresztą jak do planowanej reformy rolnej, widząc w tych instytucjach tendencje naruszające prawo własności ${ }^{39}$. Wszystko to nie sprzyjało dążeniu do radykalnych zmian, lecz raczej do ewolucyjnego przekształcania środowiska pracy i cechujących je stosunków władzy - podporządkowania.

$Z$ tego punktu widzenia liczył się nie tylko sam charakter i zakres uprawnień przyznawanych radom zakładowym, lecz również realne możliwości czynienia z nich użytku oraz perspektywy skuteczności takiego działania. Niezależnie od formalnych uchwał i środków prawnych, mających zapewnić ich przestrzeganie, wydawało się ważne stworzenie forum obligatoryjnych spotkań i konfrontacji

${ }^{39}$ Por. A. Bień, Bóg wyżej, dom dalej (1939-1949), Warszawa 1991, s. 113. 
stanowisk, w której racje kierownictwa zakładu pracy zderzałyby się z racjami załogi, skłaniając obie strony do wypracowywania optymalnych rozwiązań ${ }^{40}$. Tym bardziej że domenę działalności rad zakładowych miało stanowić konstruktywne kształtowanie życia wewnętrznego zakładu, a nie wkraczanie w sferę spraw konfliktowych.

Funkcjonowanie rad zakładowych miało stworzyć płaszczyznę oddziaływań, sprzyjających kształtowaniu się klimatu rzeczowych narad oraz lepszemu zrozumieniu źródeł konfliktów i kontrowersji w środowisku pracy. W tym sensie system rad zakładowych został pomyślany jako prospektywny, miał on bowiem przyczyniać się do kształtowania tych wartości, w imię których zamierzano powołać go do życia. Systemowi temu przypisywano też oddziaływanie wychowawcze, polegające na podnoszeniu kwalifikacji niezbędnych w społecznym działaniu i przygotowywaniu szerokich kręgów pracowniczych do pełnienia odpowiedzialnych zadań ${ }^{41}$.

Zgodnie z powyższym założeniem, system określony omówionymi przez nas przepisami stanowił niezbędne „minimum prawne”, aby zapewnić „dobry układ stosunków osobowych w nowoczesnym zakładzie pracy"ł2. Uprawnienia rady zakładowej, wchodzące w zakres tego minimum, nie mogły podlegać ograniczeniu na drodze pozaustawowej. Przewidywano natomiast możliwość ich wzbogacenia postanowieniami układów zbiorowych pracy. Na tej drodze mogło w szczególności następować:

a) rozszerzanie zadań rady odnoszących się do kształtowania wewnętrznego życia zakładu pracy;

b) nadawanie niejednomyślnym uchwałom rady w powyższych sprawach charakteru wiążącego ${ }^{43}$;

c) upoważnienie rady do omawiania spraw z zakresu kierowania i zarządzania zakładem pracy $\mathrm{z}$ wyłączeniem jednak prawa wydawania $\mathrm{w}$ tym zakresie zaleceń (art. 14 ust. 2).

Rozszerzenie zakresu zadań rady, objęte punktem „a” mogło również być dokonane jednomyślną uchwałą rady ze skutkiem trwałym na przyszłość.

Stwarzając taką perspektywę, zmierzano do nadania systemowi rad zakładowych charakteru „otwartego" ${ }^{44}$, ewoluującego w kierunku rozszerzania zadań i uprawnień rady na drodze pozaustawowej, w miarę uzyskiwania społecznej akceptacji dla takich zmian. W związku z przewidywaną $\mathrm{w}$ okresie powojennym radykalizacją postaw pracowniczych i wzrostem wpływów ruchu zawodowego

${ }^{40}$ „Sama koncepcja rady w swych podstawowych założeniach odrzuca papierkowe uchwały, a opiera się na oddziaływaniu przez osobiste, bezpośrednie zetknięcie” (Uzasadnienie, s. 16).

${ }^{41}$ Ibidem, s. 2.

${ }^{42}$ Uzasadnienie (krótsza wersja), s. 1.

${ }^{43} \mathrm{~W}$ tym przypadku kierownikowi zakładu pracy miało przysługiwać prawo sprzeciwu, podobnie jak w stosunku do uchwał dotyczących ustanowienia regulaminu pracy (art. 18 ust. 2).

${ }^{44}$ Uzasadnienie (krótsza wersja), s. 2. 
perspektywa taka mogła wydawać się całkowicie realna; co więcej należało liczyć się z wysuwaniem postulatów wykraczających poza powyższy schemat.

Przedstawiona charakterystyka kompetencji rad zakładowych wymaga jeszcze ważnego dopełnienia. W niektórych bowiem rodzajach zakładów pracy kompetencje te miały ulec znacznemu rozszerzeniu. Dotyczyło to w szczególności przedsiębiorstw należących do spółek akcyjnych ${ }^{45}$ i spółek z ograniczoną odpowiedzialnością o większym kapitale zakładowym (określonym wówczas kwotą ponad $250000 \mathrm{zł}$ ). W przedsiębiorstwach tych radom zakładowym miało przysługiwać prawo udziału w wykonywaniu społecznej kontroli spółki przez przedstawicieli biorących udział w walnym zgromadzeniu akcjonariuszy (bądź zebraniu wspólników) z głosem doradczym. Przedstawiciele ci mieli wykonywać uprawnienia akcjonariuszy bądź udziałowców, obejmujące możność zapoznawania się z biegiem spraw spółki oraz zgłaszania uwag nie tylko władzom spółki, lecz również samorządowi społeczno-gospodarczemu. Miał też na nich spoczywać obowiązek składania sprawozdań z udziału w walnych zgromadzeniach zarówno radzie zakładowej, jak i organom samorządu powołanym do sprawowania nadzoru nad ich działalnością (art. 43).

Regulacji tej przyświecała koncepcja wzmożenia kontroli społecznej nad funkcjonowaniem spółek rozporządzających znacznymi kapitałami, pochodzącymi od nieokreślonego bliżej grona osób oraz rozwijającymi niejednokrotnie działalność gospodarczą o dużej publicznej doniosłości. Spodziewano się przy tym, że przedstawiciele pracowników będą mogli wnieść do tej kontroli większą znajomość rzeczy i większe zainteresowanie niż przedstawiciele drobnych akcjonariuszy czy udziałowców i że będą mogli tym samym przeciwdziałać skuteczniej machinacjom kapitału, zwłaszcza zagranicznego, godzącym w interes przedsiębiorstw i w interes publiczny ${ }^{46}$.

Prawo uczestniczenia $\mathrm{z}$ głosem doradczym w organach kontrolnych zostało również przyznane radom zakładowym w przedsiębiorstwach, bankach $\mathrm{i}$ instytucjach finansowych, należących do państwa i do związków samorządowych (art. 42). W pierwotnym tekście dekretu przewidywano także udział delegatów rad zakładowych w zarządzie tych przedsiębiorstw i instytucji. Oba te uprawnienia miały przy tym dotyczyć również przedsiębiorstw prywatnych, mających charakter użyteczności publicznej, takich jak elektrownie i młyny ${ }^{47}$. W ostatecznie przyjętym tekście dekretu unormowania te zostały jednak pominięte.

Niezależnie od kompetencji przysługujących radzie zakładowej in corpore niektóre zadania i odpowiadające im uprawnienia miały być udziałem

\footnotetext{
${ }^{45}$ Podobne rozszerzenie uprawnień kontrolnych rad zakładowych przewidziano w prawie francuskim (A. Brun, H. Galland, op. cit., s. 269 i n.).

${ }^{46}$ Uzasadnienie, s. 25.

${ }^{47}$ Przepisy te miały jednak wejść w życie nie od razu, lecz w terminie oznaczonym przez Ministra Pracy (ibidem, s. 26).
} 
poszczególnych radnych. Należało do nich: czuwanie nad przestrzeganiem zasad bezpieczeństwa i higieny pracy, przygotowywanie projektów list urlopowych, podejmowanie prób pojednania w sporach wynikających ze wspólnej pracy, sprawdzanie zapisów w księgach mających wpływ na wymiar wynagrodzeń za pracę (art. 15), zwoływanie w porozumieniu z kierownikiem zakładu zebrań załogi (art. 36 ust. 4).

Natomiast zarówno rada in corpore, jak i poszczególni radni zostali pozbawieni prawa występowania na zewnątrz zakładu pracy (art. 16 ust. 1). Jedyny wyjątek w tym względzie dotyczył obowiązku informowania organów administracji pracy, a także izb pracy i związków zawodowych, na ich żądanie, o przestrzeganiu w zakładzie ustawowego i układowego prawa pracy (art. 15 ust. 2). Radni mogli również komunikować się bezpośrednio z izbą pracy i z organami administracji pracy (art. 16 ust. 2).

Rady zakładowe uzyskały w świetle postanowień dekretu pozycję niezależną od związków zawodowych ${ }^{48}$, nie oznaczało to jednak braku wszelkich powiązań prawnych pomiędzy tymi instytucjami. Niektóre przepisy dekretu przyznawały pewne kompetencje związkom zawodowym. Należał do nich wspomniany wyżej przepis dający przedstawicielom związkowym prawo obecności przy czynnościach komisji wyborczych do rad zakładowych oraz wnoszenia sprzeciwów i zażaleń. Związki mogły również wpływać na zakres zadań i uprawnień rad zakładowych poprzez układy zbiorowe pracy, przyczyniając się do rozszerzenia tych uprawnień poza ustawowe minimum. Wpływ związków mógł też dotyczyć samego składu rady, gdyż w drodze układowej można było zastrzec, że prawo wybieralności będzie przysługiwało wyłącznie pracownikom zrzeszonym (art. 26 ust. 5) ${ }^{49}$. Opinia związków była wymagana przy wydawaniu przez Ministra Pracy i Opieki Społecznej przepisów wprowadzających w niektórych rodzajach zakładów pracy odchyleń od ogólnie obowiązujących zasad (zastrzeżenie przewodnictwa w radzie dla kierownika zakładu, zastąpienie regulaminu pracy stanowionego przez radę instrukcjami służbowymi, art. 56 ust. 1, pkt b i c).

Związki zawodowe miały też, jak już stwierdzono, prawo żądania od radnych zakładowych informacji o przestrzeganiu postanowień układowych i przepisów prawa. Jak widać, uważano za rzecz oczywistą, że związki zawodowe będą zapoznawały się z warunkami pracy w miejscu jej wykonywania i dążyły do jej optymalizacji. Należało również liczyć się z faktem, jakkolwiek żaden przepis dekretu o tym nie wspominał, że związki zawodowe będą obecne w zakładach pracy

${ }^{48}$ „Związkom zawodowym pracowników nie wyznacza dekret żadnej pozycji prawnej w stosunku do rad zakładowych" (ibidem, s. 8). Z dalszych stwierdzeń wynikały jednak znaczne możliwości oddziaływania związków na funkcjonowanie i „realizację celów” rad zakładowych.

${ }^{49}$ Uzasadnieniem tego przepisu było przekonanie, że „zrzeszeni stanowią element bardziej uspołeczniony”. Przywilej ten miał przy tym dotyczyć wszystkich pracowników zrzeszonych „bez względu na przynależność do takich czy innych ugrupowań” (ibidem, s. 18). 
przez swoich przedstawicieli i ew. komórki organizacyjne. Z samego charakteru związków musiało przy tym wynikać ich oddziaływanie na stosunki pracy oraz na postawy pracowników i układ sił społecznych w zakładach pracy, a tym samym na warunki i możliwości funkcjonowania rad zakładowych.

Oddziaływanie to należało uznać za tym ważniejsze, że regulacja prawna stwarzała w istocie jedynie ogólne ramy dla ich aktywności, natomiast jej charakter i skuteczność musiały być zależne od kontekstu społecznego i od procesów stymulowanych przez różne czynniki wpływające na postawy członków społeczności zakładowej i na jej faktyczną pozycję w stosunku do kierownictwa zakładu pracy. Okoliczności te mieli na uwadze autorzy projektu dekretu, stwierdzając w uzasadnieniu, że ,związki zawodowe mogą przyczynić się bardzo znacznie do realizacji celów rady (zakładowej)" poprzez wykonywanie swych zadań ${ }^{50}$.

Odrębną kwestię stanowił stosunek rad zakładowych do izb pracy, które jako organy samorządu społeczno-gospodarczego, czy też - jak to niekiedy formułowano „organy gospodarczego samorządu pracy”, miały oddziaływać na „całokształt spraw żywotnych dla świata pracy"52. Podstawową sprawę stanowiło wprawdzie określenie pozycji izb pracy w stosunku do związków zawodowych, wokół której powstawały, jak już wspomniano, poważne kontrowersje.

Organy samorządu społeczno-gospodarczego, a zwłaszcza izby pracy, miały jednak bezpośrednie odniesienie nie tylko do ruchu zawodowego, lecz także do rad zakładowych. Można by nawet uznać, że ta ostatnia relacja nabierała szczególnego znaczenia, gdyż rady zakładowe ze względu na swój skład i charakter zadań stanowiły jak gdyby lokalny odpowiednik samorządu społeczno-gospodarczego, powołany do jednoczenia sił reprezentujących różne czynniki produkcji. Nieprzypadkowo w uzasadnieniu projektu dekretu stwierdzono, że rady zakładowe są ,jak gdyby rzutem (tego samorządu) na płaszczyznę poszczególnych zespołów wytwórczych” oraz określono je jako jego ,najmniejszą komórkę”, jednoczącą w sobie ,pracę kierowniczą i zależną" ${ }^{53}$. Okoliczność ta zbliżała do siebie obie te instytucje, pomimo że miały one działać na odległych od siebie płaszczyznach oraz stwarzała pomiędzy nimi więź, która - w odróżnieniu od relacji pomiędzy radami i związkami - uzyskała również bezpośredni wyraz prawny.

Zbliżenie to dotyczyło jednak, inaczej niż w przypadku związków zawodowych, nie tyle samych izb pracy, co przede wszystkim całej instytucji samorządu społeczno-gospodarczego jako skupiającej w sobie wszystkie siły produkcyjne, a nie tylko przedstawicielstwo świata pracy. Znalazło to wyraz w przepisach dekretu, które samorządowi społeczno-gospodarczemu powierzały nadzór i opiekę nad radami zakładowymi (art. 3), a także przewidywały przekazywanie do niego

\footnotetext{
${ }^{50}$ Ibidem, s. 8. Por. także przypis 49.

${ }^{51}$ Tezy (teza 2).

52 Ibidem (teza 9).

${ }^{53}$ Uzasadnienie, s. 7.
} 
spraw konfliktowych (sprzeciw kierownika zakładu pracy w stosunku do uchwał rady ustanawiającej regulamin pracy, art. 17 ust. 4; nieuwzględnianie przez niego powtarzanych zaleceń rady, art. 18 ust. 5). Przepisy te stawiały samorząd społeczno-gospodarczy w pozycji nadrzędnej w stosunku do rad zakładowych, jakkolwiek nie dawały mu prawa podejmowania wiążących decyzji ani narzucania radom swego stanowiska.

Inne przepisy dekretu zawierały jednak odniesienia nie do samorządu społeczno-gospodarczego w całości, lecz do jego członu, jaki miały stanowić izby pracy. I tak, izby pracy zostały w pewnych okolicznościach upoważnione do powoływania komisji organizujących wybory do rad zakładowych (art. 25 ust. 1). Izbom pracy należało również notyfikować nieobecność kierownika zakładu, uniemożliwiającą odbycie posiedzenia rady zakładowej (art. 33 ust. 3). Prawo obecności na zebraniach rady przyznano natomiast szeroko przedstawicielom samorządu społeczno-gospodarczego, obok przedstawicieli jego członów: izby pracy, a także izby przemysłowo-handlowej (art. 34 ust. 1). Do izby pracy należało wreszcie kierować sprawy, w których powstała trudność dokonania uzgodnień pomiędzy kierownikiem zakładu pracy a mężem zaufania w małych zakładach, w których nie przewidywano powoływania rad zakładowych (art. 37 ust. 3).

Regulację tę cechował brak precyzji i konsekwencji w określaniu powiązań prawnych pomiędzy radami a organami samorządu społeczno-gospodarczego. Miało to swoją przyczynę w niedopracowaniu koncepcji programowych, dotyczących struktury i roli tej ostatniej instytucji. Prace prowadzone w tym kierunku wzbudziły wiele kontrowersji i nie przyniosły jasno określonych rozwiązań. Nie pozwoliło to na wyraźniejsze oznaczenie ram ustroju pracy, w jakich miała się rozwijać działalność rad zakładowych ${ }^{54}$. Sprawy te wykraczają poza tematykę omawianą w tej części rozdziału, powrócimy jednak do nich w dalszym toku rozważań.

Cechę charakterystyczną modelu rad zakładowych, przyjętego w dekrecie z 1 VIII 1944 r., stanowiło nie tylko włączenie do ich składu naczelnego kierownictwa zakładu, lecz także oszczędne posługiwanie się prawem w określaniu ich kompetencji i nadawaniu wiążącej mocy jej decyzjom. Właściwością tego modelu było przywiązywanie głównej wagi do stworzenia form organizacyjnych i płaszczyzny wzajemnych oddziaływań, pobudzających do współpracy i jednoczących społeczność zakładową, unikanie natomiast - poza niezbędnym minimum - formalizowania wzajemnych stosunków między załogą i kierownikiem zakładu oraz wprowadzania procedur narzucanych pod rygorem przymusu. Nacisk społeczny miał tu odgrywać większą rolę niż sankcje prawne, a korzyści płynące z szeroko pojętego współdziałania miały oddziaływać wychowawczo i torować drogę

\footnotetext{
${ }^{54} \mathrm{~W}$ Uzasadnieniu podkreślono natomiast wyraźnie, że rady zakładowe „nie są zawieszone w próżni" ze względu na ich powiązania nie tylko z ruchem zawodowym, lecz także z izbami pracy i innymi organami samorządu społeczno-gospodarczego (ibidem, s. 6).
} 
stopniowemu rozszerzaniu kompetencji rad zakładowych i umacnianiu ich pozy$\mathrm{cji}^{55}$. Ostrożnie został natomiast określony podstawowy zakresy tych kompetencji, wyłączający wszelką ingerencję w sprawy kierownika i zarządzania zakładem pracy.

Trudno zaprzeczyć, że przedstawiona koncepcja miała pewne racjonalne podstawy. Wiadomo bowiem od dawna, że w dziedzinie zbiorowych stosunków pracy układ sił i faktycznych stosunków ma często w praktyce większe znaczenie niż regulacja prawna. Wiadomo także, że samo przyznanie organom społecznym określonych uprawnień nie zawsze jest równoznaczne z możliwością czynienia z nich pełnego użytku. Porównywanie zadekretowanych kompetencji nie może zatem samo przez się przesądzać o społecznej wartości przyjętych rozwiązań prawnych, zwłaszcza jeśli mieć na uwadze nie tylko formalne wykorzystywanie tych kompetencji, lecz także osiąganie poprzez to zamierzonych celów. Ponadto porównawczy przegląd ustawodawstwa różnych krajów pokazuje, że zakres kompetencji rad zakładowych (i instytucji o zbliżonym charakterze) skupiał się głównie wokół spraw pracowniczych i socjalnych, a tylko w ograniczonym stopniu, bez głosu stanowiącego, dotyczył spraw gospodarczo-produkcyjnych ${ }^{56}$. Dekret z 1 VIII 1944 r. nie odbiegał więc w tym względzie od rozwiązań powszechnie stosowanych.

Trzeba też mieć na uwadze fakt, że dekret z 1 VIII 1944 r. miał charakter nowatorski, wprowadzał bowiem instytucję poprzednio w Polsce (poza Górnym Śląskiem) zupełnie nieznaną i jako taki spotykał się, pomimo ostrożności swych sformułowań, z ostrą krytyką środowisk zachowawczych.

Niemniej jednak trudno oprzeć się wrażeniu, że inicjatorzy tego aktu wiązali z nim nadzieje trudne do spełnienia. Nie wydaje się bowiem, aby mógł on sam przez się dokonać przełomu w świadomości pracowników oraz wzbudzić w nich przekonanie, że odtąd wykonywana przez nich praca miałaby stać się ,pracą na swoim"s7. Tego rodzaju przemiany postaw ludzkich są trudne do osiągnięcia i postępują zazwyczaj powoli pod wpływem różnych czynników. Zmiany prawne i instytucjonalne odgrywają w tym zakresie zazwyczaj wtórną rolę, także wówczas gdy mają bardziej radykalny charakter. Wymownych przykładów w tym względzie dostarczyła praktyka lat powojennych w Polsce, która nie przeorała świadomości pracowniczej, pomimo głębokich przeobrażeń ustrojowych, związanych z upaństwowieniem środków produkcji. Doświadczenia te mogą raczej dostarczać argumentów na rzecz słuszności polityki zmierzającej do stopniowych zmian ewolucyjnych w sferze instytucjonalnej i towarzyszących im postaw ludzkich.

${ }^{55}$ Takie tendencje można wyraźnie odczytać z treści Uzasadnienia, s. 1-2.

${ }^{56}$ Por. W. Däubler, Das Grundrecht auf Mitbestimmung, Frankfurt am Main 1973, s. 14 i n.; A. Braun, H. Galland, op. cit., s. 251 i n. Odrębnie oceniać należy organy powołane do udziału w zarządzaniu zakładami pracy (W. Däubler, op. cit., s. 129 i n.).

${ }^{57}$ Uzasadnienie, s. 11. 
Odnotować jednak wypada, że treść dekretu z 1 VIII 1944 r. spotkała się z krytyką nie tylko ze strony sfer zachowawczych, lecz również ośrodków o przeciwnej orientacji, które zarzucały tej regulacji minimalizm i kompromisowośćs ${ }^{58}$. Podnoszono w nich również konieczność liczenia się ze spontanicznym ruchem tworzenia reprezentacji pracowniczych w zakładach pracy po ustaniu okupacji, mogącym stwarzać fakty dokonane, wykraczające poza regulacje prawne ${ }^{59}$, i to zanim powstanie możliwość wprowadzenia ich w życie.

Przy wszelkich zastrzeżeniach trzeba jednak uznać, że dekret z 1 VIII 1944 r. tworzył konsekwentnie pomyślaną instytucję związaną z ogólniejszym kierunkiem przemian, torujących drogę nowemu ustrojowi pracy. Był też jedynym, przygotowanym $\mathrm{w}$ okresie okupacji, aktem $\mathrm{z}$ tej dziedziny ubranym w wykończoną pod względem formalnym szatę prawną, czym wyróżniał się spośród opracowań mających ogólny charakter postulatywny ${ }^{60}$.

$\mathrm{Na}$ uwagę zasługują również niektóre rozwiązania prawne zastosowane w dekrecie z 1 VIII 1944 r. Należy do nich konstrukcja zakładu pracy jako instytucji będącej terenem działania rad zakładowych, ale mającej zastosowanie także $\mathrm{w}$ prawie stosunku pracy ${ }^{61}$. Większe jeszcze znaczenie miała wyrażona w tym akcie zasada jedności pracowniczej, odrzucająca podział na robotników i pracowników umysłowych, a także odrębność statusu funkcjonariuszy publicznych ${ }^{62}$. Znalazła ona silny wyraz w konstrukcji rad zakładowych, wpłynęła również na treść innych opracowań programowych, przygotowanych przez Departament Pracy i Opieki Społecznej w przedmiocie związków zawodowych i prawa pracy. Można by wskazać także na inne aspekty omawianego aktu, mające odniesienie do różnych instytucji prawa pracy ${ }^{63}$.

\footnotetext{
${ }^{58}$ Por. uwagi Biura Studiów Gospodarczo-Przemysłowych, w których domagano się określenia pola „konkretnej współpracy” ze strony rad oraz ich udziału w kierownictwie i kontroli (AAN, KC PZPR 203/III-29, s. 1 oraz 20-22).

${ }^{59}$ Ibidem, s. 1.

${ }^{60}$ Taki charakter miał Program Polski Ludowej opracowany w sierpniu 1941 r. i wyrażający stanowisko PPS-WRN (A. Friszke, O kształt Niepodległej, Warszawa 1989, s. 433 i n.). Z. Załęski w broszurze konspiracyjnej Wspólny Dom (Warszawa 1943) postulował utworzenie rad zakładowych jako prawnie uznanego przedstawicielstwa pracowników, powołanego do współdziałania z kierownictwem w sprawie ustalania ogólnych warunków pracy w przedsiębiorstwie (ibidem, s. 79). Deklaracja programowa Polskiej Partii Robotniczej O co walczymy (Warszawa 1943) postulowała powierzenie kontroli nad produkcją znacjonalizowanych przedsiębiorstw komitetom fabrycznym (ibidem, s. 8).

${ }^{61}$ Uzasadnienie, s. 1.

${ }^{62}$,Jedna jest tylko i wewnętrznie jednolita rada zakładowa. Podziału na przedstawicielstwo pracowników umysłowych i przedstawicielstwo robotników nie dałoby się uzasadnić, tym bardziej że samo rozróżnienie tych kategorii staje się chwiejne. Coraz intensywniejsze przenikanie kultury w dół, a poczucia obowiązku w górę, daje jako skutek zespolenie kultury i pracy, jedność socjologiczną inteligencji kierowniczej i pracy wykonawczej (ibidem, s. 7).

${ }^{63} \mathrm{~W}$ szczególności do instytucji wypowiedzenia umowy o pracę, które zgodnie z dekretem powinno być kontrolowane nie tylko pod kątem rzeczowego uzasadnienia, lecz także słuszności,
} 
Wszystko to uzasadnia bliższe zainteresowanie treścią dekretu z 1 VIII 1944 r. jako aktu odzwierciedlającego pewien etap rozwojowy kształtowania się polskiej myśli społeczno-prawnej w kwestii ustroju pracy.

\section{Związki zawodowe}

Problematyka związków zawodowych rysowała się w pracach programowych Departamentu Pracy i Opieki Społecznej odmiennie niż zakładowego przedstawicielstwa w przedsiębiorstwach. Decydował o tym sam charakter związków jako organizacji powołanej przede wszystkim do reprezentowania i obrony interesów pracowniczych, a nie do konstruktywnej współpracy z czynnikami gospodarczymi. Postulowana planowość gospodarki stwarzała wprawdzie dla związków zawodowych nowe ramy i nie mogła pozostać bez wpływu na formy ich działalności. Wynikające stąd priorytetowe dążenie do rozwiązywania spraw spornych bezkonfliktowo oraz unikanie ostrzejszych zatargów nie mogło jednak wyłączać podejmowania bezpośredniej próby sił w przypadkach, gdy wymagało tego dobro pracowników oraz autorytet organizacji związkowych.

Nie podlegał zatem dyskusji fakt, że związki będą musiały wziąć na siebie w tym układzie ciężar kontestacji i stawać się stroną w nieuniknionych konfliktach, wykorzystując przy tym przysługujące im narzędzie nacisku i walki w obronie bieżących interesów pracowniczych, a więc nie tylko uczestniczyć w rokowaniach zbiorowych i procedurach rozjemczych, lecz również organizować własne wystąpienia (w postaci strajków, bojkotów itp.). Należało wobec tego dążyć nie tylko do utrzymania poprzedniej pozycji związków zawodowych, lecz także do wzmocnienia ich struktur organizacyjnych.

Odrębność prac programowych nad ruchem zawodowym polegała również na tym, że musiały one, inaczej niż w przypadku rad zakładowych, liczyć się ze stanem zastanym, a ściślej biorąc $\mathrm{z}$ realiami okresu międzywojennego tak w sferze sytuacji faktycznej, jak i prawnej. Oba te aspekty sprawy wpłynęły decydująco na obraz sytuacji społecznej lat międzywojennych i tkwiły nadal mocno w świadomości mas pracowniczych, a równocześnie nasuwały problemy delikatne i trudne zarówno ze względu na newralgiczny charakter wszelkich kwestii dotyczących ruchu zawodowego, jak i głębokie zakorzenienie jego form w procesie historycznym.

Struktury organizacyjne ruchu zawodowego ukształtowały się w wyniku ewolucji, której początki sięgały pierwszych lat wieku XX w kraju pod zaborami, a częściowo także w ośrodkach polskiej emigracji zarobkowej (w Westfalii i Nadrenii).

a więc zgodności z powszechnie akceptowanymi regułami pozaprawnymi. W prawie PRL reguły te określono później jako zasady współżycia społecznego. 
Ewolucja ta doprowadziła do zróżnicowania form i kierunków ruchu zawodowego, nie tylko ze względu na odrębności sytuacji w różnych zaborach, lecz także z uwagi na wpływy ośrodków politycznych (partii), którym związki zawodowe były od początku silnie podporządkowane. W okresie międzywojennym zarysował się wyraźnie podział ruchu zawodowego na różne kierunki i odpowiadające im centrale.

Najsilniejszy odłam stanowiły tzw. związki klasowe, pozostające pod wpływami PPS, których centrala przyjęła nazwę Związek Stowarzyszeń Zawodowych. W 1931 r. doszło w nich jednak do rozłamu na skutek wyodrębnienia się tzw. Centrali Zjednoczenia Klasowych Związków Zawodowych, o podobnej orientacji ideowej, ale wyraźnej odrębności organizacyjnej, przy znacznie mniejszych wpływach w środowisku pracowniczym ${ }^{64}$.

Drugi z kolei, pod względem społecznego znaczenia, odłam ruchu, ukształtowany jako Zjednoczenia Zawodowe Polskie, obejmujący swymi wpływami głównie Górny Śląsk, Poznańskie i Pomorze, działał pod auspicjami Narodowej Partii Robotniczej i głosił bardziej umiarkowany program społeczny. Rozłam, do którego doszło w roku 1925 w NPR, znalazł odbicie w powstaniu odrębnej centrali Polskich Związków Zawodowych „Praca” o bardziej radykalnej orientacji, umiejscowionej przede wszystkim w Lodzi.

Trzeci kierunek ruchu zawodowego: chrześcijańsko-społeczny, stojący na gruncie nauki społecznej Kościoła i będący pod wpływami Chrześcijańskiej Demokracji, utworzył w 1931 r. wspólną centralę w Warszawie pod nazwą „Chrześcijańskie Zjednoczenie Zawodowe RP”, co nie doprowadziło jednak do całkowitego połączenia tych związków pod wspólną egidą ${ }^{65}$.

Jak widać, trzy podstawowe odłamy ruchu zawodowego: związki klasowe, „polskie” i chrześcijańskie, nie zdołały zapewnić całkowitej jedności w swych szeregach. W 1931 r. scena działalności związkowej skomplikowała się jeszcze bardziej przez utworzenie nowej centrali pod nazwą „Związek Związków Zawodowych" (ZZZ), która została powołana do życia przez obóz pomajowy $\mathrm{w}$ celu rozpowszechnienia jego wpływów w środowisku robotniczym i osłabienia pozycji istniejących dotychczas centrali ruchu zawodowego. Związek ten przeszedł następnie znamienną ewolucję, wynikającą z „obiektywnej niemożliwości pogodzenia stosunkowo radykalnych i antykapitalistycznych koncepcji z klasową treścią przewrotu majowego" ${ }_{66}$ i stanął w opozycji do prób faszyzacji kraju oraz zbliżył się do ideologii syndykalistycznej. Obiektywnie należy stwierdzić, że należał do najbardziej wpływowych central związkowych, skupiając w roku 1935

${ }^{64}$ J. Malański, Pracownicze związi zawodowe w Polsce, Warszawa 1934, s. 47 i n.

${ }^{65}$ Ibidem, s. 67 i n. Bardziej szczegółową charakterystykę rozwoju tych wszystkich kierunków podaje S. Rychliński, Zasadnicze kierunki robotniczego ruchu zawodowego w Polsce, Warszawa 1929 (w odniesieniu do okresu pod zaborami, s. 9 i n.; a w odniesieniu do Niepodległej Polski do roku 1927, s. 26 i n.). Por. także J.G. Wengierow, Przedstawicielstwo pracownicze a państwo, Warszawa 1935, s. 39 i n.

${ }^{66}$ S. Ajzner, Związek Związów Zawodowych (1931-1939), Warszawa 1979, s. 426. 
w przybliżeniu tę samą liczbę członków co Zjednoczenie Zawodowe Polskie, a znacznie większą niż pozostałe centrale, poza związkami klasowymi zgrupowanymi w Związku Stowarzyszeń Zawodowych, który zachował najmocniejszą pozycję w polskim ruchu zawodowym ${ }^{67}$.

Przedstawiony powyżej obraz nie był jeszcze kompletny, nie obejmował bowiem wielu pomniejszych grup związkowych i związków niezrzeszonych w żadnej centrali („dzikich”), których znaczna część pozostawała pod wpływami komunistycznymi ${ }^{68}$. Poza związkami robotniczymi odrębnie ukształtował się ruch zawodowy pracowników umysłowych, który zjednoczył się w 1932 r. we wspólnej Centrali ${ }^{69}$.

Wszystkie związki zawodowe zrzeszające pracowników najemnych, łącznie z robotnikami rolnymi, liczyły w 1935 r. ogółem 941 tys. członków, z których jednak tylko 618 tys. opłacało składki. Ogólna liczba związków zawodowych wynosiła w tym czasie 298, co pośrednio daje pojęcie o ich rozproszeniu i słabości organizacyjnej ${ }^{70}$. Na jeden związek w całym ruchu zawodowym przypadało zaledwie 3200 członków, a biorąc pod uwagę tylko związki robotnicze - 4000 członków, w tym zaledwie 2400 płacących składki. Decydowało to o słabości finansowej i majątkowej związków ${ }^{71}$.

Podważała pozycję związków ich zależność od partii politycznych i wynikające stąd konflikty pomiędzy związkami reprezentującymi różne orientacje ideologiczne. Wpływało to z kolei negatywnie na postawy członków ${ }^{72}$, tym bardziej że sytuacja kryzysowa wczesnych lat trzydziestych redukowała poważnie szanse podejmowania przez związki skutecznych akcji strajkowych. Wynikała stąd pilna potrzeba wzmocnienia ruchu zawodowego i przeciwdziałania jego rozbiciu. Propozycje zmierzające w tym kierunku były formułowane już przed wojną, z tym że były one uwikłane w poważne konflikty interesów i kontrowersje ideologiczne, co stanęło na przeszkodzie wypośrodkowaniu optymalnych rozwiązań ${ }^{73}$.

Cały ten układ stosunków z okresu międzywojennego należało mieć na uwadze w pracach programowych prowadzonych w okresie okupacji, ponieważ stanowił on naturalny punkt odniesienia dla oceny projektów na przyszłość i decydował pośrednio o szansach ich akceptacji.

${ }^{67}$ W 1935 r. Związek Stowarzyszeń Zawodowych skupiał 284 tys. członków, Zjednoczenie Zawodowe Polskie - 150 tys., Związek Związków Zawodowych - 148 tys.; pozostałe centrale związkowe niepomiernie mniej (Mały rocznik statystyczny, Warszawa 1939, s. 285).

${ }^{68}$ J. Malański, op. cit., s. 70 i n.

${ }^{69}$ Unia Związków Zawodowych Pracowników Umysłowych w Polsce. Por. J. Malański, op. cit., s. 78 i n.; J.G. Wengierow, op. cit., s. 55 i n.

${ }^{70}$ Maty rocznik..., s. 285.

${ }^{71}$ Według danych z 1932 r. obracały one rocznie sumą wynoszącą mniej niż 20 zł na jednego zorganizowanego członka (J.G. Wengierow, op. cit., s. 40-41).

${ }^{72}$ Ibidem, s. 42.

${ }^{73}$ Por. M. Święcicki, Instytucja.., s. 311 i n. oraz J.G. Wengierow, op. cit., s. 209 i n. 
Wtórne znaczenie miał natomiast $\mathrm{z}$ tego punktu widzenia przedwojenny stan prawny. Ukształtował go przede wszystkim dekret z 8 II 1919 r., który usankcjonował wolność związkową, ograniczając formalności związane z tworzeniem związków do rejestracji uzależnionej wyłącznie od zgodności z prawem ich statutów. Dekret ograniczał do minimum bieżącą kontrolę nad działalnością związków, powierzając je wyłącznie inspekcji pracy, a prawo ich zawieszania lub rozwiązania sądom. Dekret uznawał związki zawodowe za reprezentację ogółu pracowników, a więc zarówno zrzeszonych, jak i niezrzeszonych, nadając w ten sposób związkom charakter publicznoprawny i odrzucając cywilistyczną konstrukcję, opartą na pełnomocnictwie ze strony członków. Dekret nie narzucał związkom żadnej określonej sfery działalności, jakkolwiek sugerował pośrednio organizowanie ich według gałęzi pracy (a nie zawodów) ${ }^{74}$. Liberalizm dekretu wyraził się w dopuszczeniu do zakładania związków już nawet przez trzech pracowników (tres faciunt collegium!), do sprawy tej wypadnie nam jeszcze powrócić.

Późniejsze zmiany tych przepisów nastąpiły na mocy prawa o stowarzyszeniach z 27 X 1932 r., które poddało związki zawodowe, łącznie z prawem prewencyjnego ich zawieszania, nadzorowi organów administracji ogólnej. Stanowiło to przejaw ogólniejszych tendencji do ustanowienia systemu rządów autorytarnych, o czym świadczyło również późniejsze wprowadzenie przymusowego rozjemstwa i ograniczenie wolności strajku ${ }^{75}$.

Zajęcie stanowiska wobec tych regulacji wydawało się nie nastręczać szczególnych wątpliwości. Było rzeczą jasną, że prawo z 1932 r. wymaga uchylenia i że zasada wolności związkowej, wyrażona dekretem z 1919 r., zasługuje na akceptację. Powstawał natomiast problem, czy treść tego dekretu będzie odpowiadała w całej rozciągłości potrzebom okresu powojennego, a zwłaszcza postulatom wzmocnienia ruchu zawodowego i uproszczenia jego struktury organizacyjnej. Trzeba było zatem odpowiedzieć na pytanie, w jakiej mierze prawo może okazać się temu pomocne.

Sformułowany powyżej problem skupił na sobie główną uwagę Departamentu i przewijał się jako myśl przewodnia przez całokształt jego prac programowych dotyczących ruchu zawodowego. Można to prześledzić, studiując kolejne wersje proponowanych rozwiązań, których ostateczne wykrystalizowanie nasuwało widoczne trudności. Prace te nie doprowadziły, odmiennie niż w przypadku rad zakładowych, do przygotowania projektu wyrażającego ostateczne stanowisko Departamentu, nie mówiąc już o jego akceptacji przez władze Delegatury.

Jedyny dokument przedstawiony przez Departament na zewnątrz stanowiły tezy w sprawie związków zawodowych, wysłane do Rządu w Londynie jako załącznik do sprawozdania Departamentu za I kwartał 1944 r. Dokument ten

\footnotetext{
${ }^{74}$ M. Święcicki, Instytucja..., s. 25-26.

${ }^{75}$ Ibidem, s. 312 i n., 331 i n., 345 i n.
} 
sygnalizował jednak tylko kierunki poszukiwanych rozwiązań, nie rozwijając bliżej ich treści ${ }^{76}$. Owocem prac nad dekretem o związkach zawodowych było natomiast kilka zachowanych projektów, z których żaden nie przybrał formy wyrażającej ostateczne stanowisko Departamentu, jakkolwiek jeden z nich ma charakter najbardziej dojrzały i najbliższy końcowej akceptacji ${ }^{77}$. Zachowało się poza tym obszerne uzasadnienie, którego treść nawiązuje najwyraźniej, jakkolwiek nie w sposób całkowicie przekonywający, do jednego ze wspomnianych wyżej projektów, zawiera jednak również uwagi o charakterze dyskusyjnym, które nie znalazły potwierdzenia w ich treści ${ }^{78}$.

Opisany stan rzeczy nakazuje zachować dużą ostrożność w przedstawianiu poglądu Departamentu na przyszły kształt ruchu zawodowego. Na podstawie zachowanych dokumentów można bowiem odtworzyć raczej krystalizowanie się tego poglądu, który w toku kolejnych opracowań podlegał zmianom i nie przybrał ostatecznie formy dojrzałej do legislacyjnego ujęcia. W niejednej kwestii można mówić raczej o kierunkach poszukiwanych rozwiązań aniżeli o ich zdeklarowanej treści i ścisłym prawniczym sformułowaniu. Ogólne założenia struktury prawnoorganizacyjnej ruchu zawodowego przedstawiają się jednak w świetle opracowań programowych Departamentu zupełnie jasno. Najważniejszy kierunek postulowanych zmian stanowiło, jak już wspomniano, umocnienie i ujednolicenie ruchu zawodowego, warunkujące zwiększoną skuteczność jego działania. Wymagało to rozwiązania wielu kwestii na różnych poziomach jego struktury. Było przy tym rzeczą oczywistą, że wprowadzanie niezbędnych z tego punktu widzenia zmian należy zaczynać „od dołu”, tzn. od wzmocnienia poszczególnych związków stanowiących podstawowe ogniwa ruchu zawodowego.

${ }^{76}$ Nie pozwoliła na to zwięzłość tego dokumentu (14 tez na 1,5 strony).

${ }^{77}$ Zachowało się ogółem 5 projektów: (1) Dekret. Prawo związów zawodowych pracowniczych (projekt najwcześniejszy, maszynopis, s. 10, zbiory rodziny M. Święcickiego); (2) Prawo pracowniczych związków zawodowych (projekt następny w kolejności, maszynopis, S. 13, zbiory rodziny M. Święcickiego); (3) Prawo pracowniczych związów zawodowych (maszynopis gęsto zapisany, s. 7, zbiory W.S. oraz AAN, KC PZPR [bez sygnatury w oryginale - M.S.], po art. 33 stwierdzenie: „dotąd przedyskutowano szczegółowo z dyr.”, a więc S. Mateją?); (4) O pracowniczych zwiazkach zawodowych (projekt w postaci artykułowanej, oznaczony jako D. 1, s. 12, AAN KC PZPR 203/VII-35, t. 2, k. 176-187); (5) O pracowniczych zwiazkach zawodowych (projekt w postaci artykułowanej, oznaczony jako D. 2, s. 11, AAN KC PZPR 203/VII-35, t. 2, k. 122-132). Kolejności powstawania projektów 3-5 nie da się z całkowitą pewnością ustalić, jakkolwiek projekt 5 jest na pewno późniejszy od 4 . Żaden z wymienionych projektów nie przybrał postaci projektu ostatecznego, przeznaczonego do skierowania na zewnątrz jako wyraz stanowiska Departamentu. Poniżej odwołujemy się w wielu sprawach do projektów 3, 4 i 5, które są do siebie treściowo i redakcyjnie dość znacznie zbliżone.

${ }^{78}$ Uzasadnienie projektu prawa związków zawodowych (na użytek wewnętrzny), maszynopis, stron 14 (zbiory rodziny M. Święcickiego). Tekst tego uzasadnienia wykazuje najwyraźniejsze odniesienia do projektu 3. Uwagi dyskusyjne dotyczą przynależności związkowej urzędników państwowych i samorządowych. 
Związki te były, jak stwierdzono, w znacznej części organizacjami słabymi o niewielkiej liczbie członków i skromnych funduszach. Nie decydowała o tym oczywiście treść obowiązującego prawa, lecz sytuacja społeczno-polityczna i stopień świadomości klasy robotniczej ${ }^{79}$. Liberalizm prawa miał jednak w tym swój współudział, a co najmniej sankcjonował ówczesny stan rzeczy. Dopuszczenie do zakładania poszczególnych związków zawodowych przez trzech inicjatorów świadczyło o niezrozumieniu charakteru organizacji związkowych, które muszą wszak reprezentować określoną siłę społeczną, aby móc działać skutecznie. Dopuszczało też do „zachwaszczenia” pola związkowego przez organizacje słabe i efemerydalne, niemające szerszego poparcia społecznego. Narzucała się tym samym potrzeba zwiększenia wymagań co do minimalnej liczby członków założycieli. W tym względzie wszystkie projekty opracowane w Departamencie były zgodne, uzależniając powstanie jakiejkolwiek organizacji związkowej od złoże-

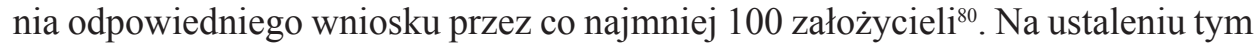
nie można jednak było poprzestać.

Nasuwała się bowiem oczywista trudność w określeniu takiej powszechnej normy minimalnej składu członkowskiego, która nie stwarzałaby nadmiernych ograniczeń w powoływaniu do życia organizacji związkowych, a równocześnie zapewniałaby tworzenie wyłącznie organizacji silnych, mogących rozwijać wszystkie formy działania właściwe ruchowi zawodowemu i skutecznie bronić interesów pracowniczych. Rozwiązaniem tego dylematu mogło być rozróżnienie w ramach ruchu związkowego na: (1) związki, które odpowiadałyby jedynie minimalnym wymaganiom co do składu członkowskiego i dysponowały ograniczonymi możliwościami działania oraz (2) związki o licznym aktywie i szerokim zasięgu wpływów, mających prawo występowania jako partner porozumień układowych, organizator strajków i uczestnik postępowania rozjemczego w zatargach zbiorowych. Rozróżnienie tego typu ukształtowało się poczynając od 1925 r. we Francji $^{81}$. Propozycja o podobnym charakterze została również wysunięta w naszym piśmiennictwie lat trzydziestych ${ }^{82}$.

Departament przyjął tę koncepcję, wahając się jedynie co do jej wyrażenia terminologicznego. O ile bowiem w tezach rozróżniał związki pełno- i niepełno-

${ }^{79}$ Tak słusznie M. Święcicki, Instytucja..., s. 26-27.

${ }^{80}$ Tak projekt 5, art. 30 ; projekt 4 , art. 35 ust. 1 ; projekt 3 , art. 35 ust. 1 .

${ }^{81}$ Polegała ona na odrębnym określeniu statusu związków najbardziej reprezentatywnych (syndicats les plus représentatifs), A. Brun, H. Galland, op. cit., t. II, s. 39 i n.; J.M. Verdier, Syndicats, Paris 1966, s. 358 i n.

${ }^{82}$ J.G. Wengierow (op. cit., s. 210 i n.) sugerował odróżnienie właściwych związków zawodowych od stowarzyszeń. Koncepcja ta musiała być znana M. Święcickiemu, gdyż pracował on w latach 1937-1939 w Ministerstwie Opieki Społecznej, w którym Wengierow należał do kadry kierowniczej. Należy zatem przyjąć, że propozycje Wengierowa nie pozostały bez wpływu na projekty Departamentu. 
prawne ${ }^{83}$, to następnie (w czterech kolejnych projektach) zastosował rozróżnienie związków i stowarzyszeń zawodowych, a w projekcie uznanym przez nas za najbardziej dojrzały (D. 2) nazwał te ostatnie, w przeciwieństwie do związków zawodowych - zespołami (ściślej pracowniczymi zespołami zawodowymi) ${ }^{84}$.

Ważniejsze od terminologicznych oznaczeń było jednak określenie progu wymagań, oddzielającego związki zawodowe od stowarzyszeń zawodowych czy zespołów. Próg ten, w projektach Departamentu, był wysoki, od związku zawodowego wymagano bowiem, aby zrzeszał co najmniej 1/10 ogółu pracowników na jego przyszłym obszarze działania bądź 1/5 pracowników już zrzeszonych ${ }^{85}$. Samo określenie tych warunków świadczyło o zasadniczej odrębności związków zawodowych od stowarzyszeń, od których wymagano jedynie, aby zrzeszały 100 członków ${ }^{86}$. Musiało to oczywiście znaleźć swe odbicie w określeniu kompetencji każdej z tych organizacji.

Odrębność związku zawodowego polegała na tym, że miał on charakter publicznoprawny i „wyrastał ponad grupę” jego założycieli ${ }^{87}$, z czym łączyło się prawo występowania nie tylko w imieniu swych członków, lecz także ogółu pracowników objętych jego zakresem działania, zarówno zrzeszonych, jak i niezrzeszonych. Mógł też zawierać układy zbiorowe pracy, regulujące warunki pracy jednych i drugich, a także uczestniczyć w procedurach pojednawczych i rozjemczych, organizować strajki i współdziałać w określonych prawem formach z organami samorządu społeczno-gospodarczego. Związek zawodowy mógł również przystępować jako rzecznik ogółu pracowników do postępowania sądowego w sprawach związanych ze stosunkiem pracy lub ubezpieczenia społecznego ${ }^{88}$.

Stowarzyszenie zawodowe (zespół) miało natomiast charakter prywatnoprawny i mogło działać wyłącznie w imieniu swych członków. Nie wyłączało to

${ }^{83}$ Tezy, pkt 3.

${ }^{84}$ Projekt 5, art. 1 ust. 2, art. 2 ust. 3, art. 19, art. 30-32. Była to terminologia niezbyt szczęśliwa i chyba niemożliwa do utrzymania. W opracowaniu naszym stosujemy konsekwentnie termin ,stowarzyszenie zawodowe".

${ }^{85}$ Projekt 3, art. 36 ust. 1; projekt 4, art. 36 ust. 1. W projekcie 5 tekst odpowiednich przepisów (art. 31 i 32) uległ zatarciu, jednakże fragmenty tekstu, jakie można odczytać, potwierdzają przyjęcie podobnych zasad. Tezy poprzestają natomiast na warunku, aby związek zrzeszał $10 \%$ ogółu pracowników danej gałęzi pracy lub zawodu. Dla porównania warto podać, że Wengierow przyjmował liczbę 2000 członków jako kryterium odróżnienia związków od stowarzyszeń. Przepisy cytowanych projektów przewidywały również pewne kryteria alternatywne, ustalane w odniesieniu do poszczególnych branż, obejmowanych zakresem działania danego związku. Wiązało się to z procedurą przekształcania stowarzyszeń (zespołów) w związki zawodowe.

${ }^{86}$ Członkowie ci powinni poza tym spełniać kryterium wieku (24 lata) i stażu pracy (2 lata w danej gałęzi pracy, a 1 rok na danym obszarze); projekt 5, art. 30 ust. 1; projekt 4, art. 35 ust. 1; projekt 3 , art. 35 ust. 1 .

${ }^{87}$ Uzasadnienie, s. 2.

${ }^{88}$ Prawa i obowiązki związków zawodowych zostały określone szczegółowo w odrębnych rozdziałach projektów (projekt 5, art. 8-14; projekt 4, art. 8-14, projekt 3, art. 8-15). 
wprawdzie zawierania przez nie układów zbiorowych pracy, ale układy takie wiązałyby wówczas tylko strony, które układ zawarły, i członków danego stowarzyszenia $^{89}$. Do obowiązków stowarzyszenia należało czuwanie nad przestrzeganiem prawa pracy, co należało również do zadań związków zawodowych. Jednakże w obradach nad układami zbiorowymi pracy ustanawianymi przy udziale związków oraz w postępowaniu pojednawczym i rozjemczym stowarzyszenia miały wyłącznie głos doradczy. Na równi ze związkami mogły natomiast prowadzić działalność samopomocową ${ }^{90}$.

Wszystkie organizacje zawodowe zostały upoważnione do działania przy wykonywaniu swych zadań ,ponad obowiązek” w ramach obowiązującego porządku prawnego ${ }^{91}$. W organizacjach tych przewidziano tworzenie sądów dyscyplinarnych, przed którymi mieliby odpowiadać zrzeszeni w nich członkowie za naruszenie obowiązków statutowych i za czyny sprzeczne z dobrymi obyczajami, przy czym kara orzeczona przez sąd działający w jednej organizacji miała obowiązywać w całym ruchu związkowym ${ }^{92}$.

Ze sprawą struktury i zakresu działania organizacji (a przed wszystkim związków) zawodowych łączyło się jeszcze kilka istotnych kwestii. Pierwsza z nich dotyczyła przynależności związkowej funkcjonariuszy publicznych. W tej sprawie stanowisko Departamentu przeszło pewną ewolucję. W jednym z pierwszych projektów rozstrzygnięto ją pozytywnie ${ }^{93}$, a obszerniejszy wywód wspierający to stanowisko znalazł się w treści Uzasadnienia ${ }^{94}$. We wszystkich późniejszych projektach odstąpiono jednak od koncepcji łączenia w tych samych związkach pracowników objętych prawem pracy i funkcjonariuszy publicznych. Stwierdzają one zgodnie, że projektowany dekret nie ma dotyczyć pracowników zatrudnionych w urzędach państwowych i samorządu terytorialnego ${ }^{95}$.

Podtrzymano natomiast „zasadę jednolitości” ruchu zawodowego, wypowiadając się za łączeniem we wspólnych związkach robotników i pracowników umysłowych. Stwierdzenie to zostało sformułowane expressis verbis w Tezach ${ }^{96}$. $\mathrm{W}$ treści żadnego z projektów dekretu nie znalazło wprawdzie wyraźnego potwierdzenia, wynikało jednak pośrednio z treści przepisów dotyczących tworzenia

${ }^{89}$ Miał tu zastosowanie art. 445 kodeksu zobowiązań z 1933 r.

${ }^{90}$ Projekt 5, art. 19; projekt 4, art. 19; projekt 3, art. 21.

${ }^{91}$ Projekt 5, art. 7 ust. 3; projekt 4, art. 7 ust. 3; projekt 3, art. 7 ust. 2.

${ }^{92}$ Przewidywano kary na czci (pozbawienie prawa udziału w organizacyjnym życiu zawodowym do lat 5) i kary pieniężne (maksimum 30-dniowy zarobek). Bliższą regulację odpowiedzialności dyscyplinarnej powierzono Ministrowi Pracy (projekt 5, art. 26; projekt 4, art. 30; projekt 3, art. 30).

${ }^{93}$ Projekt 2, art. 28 ust. 1.

${ }^{94}$ Stwierdzono tu m.in., że „każda praca jest pracą publiczną” oraz że wyodrębnienie urzędników w kastę „należy do szkodliwych przeżytków” (Uzasadnienie, s. 7-8). Argumentacja ta przypomina tę, jaką posłużono się w przypadku określenia zakresu funkcjonowania rad zakładowych.

${ }^{95}$ Projekt 5, art. 6 ust. 2; projekt 4, art. 6; projekt 3, art. 6.

${ }^{96}$ Tezy, pkt 2. 
związków zawodowych, a także ich zrzeszeń. W tym punkcie zatem zasada ,jedności pracowniczej” znalazła wyraz w prawie związkowym, podobnie jak w prawie rad zakładowych oraz $\mathrm{w}$ indywidualnym prawie pracy. Związki zawodowe miały też obejmować osoby o statusie prawnym zbliżonym do pracowniczego, w szczególności chałupników ${ }^{97}$.

Organizacje zawodowe mogły swobodnie określać swój wewnętrzny ustrój w drodze statutu, którego treść konieczna miała być ustalona przez Ministra Pracy i Opieki Społecznej w drodze rozporządzenia ${ }^{98}$. W ramach organizacji zawodowych miało być tworzone odrębne przedstawicielstwo poszczególnych zawodów i grup, a także pracowników wykwalifikowanych i odrębnie pracowników małych zakładów pracy i chałupników. Miały też działać sekcje: młodocianych i kobiet. Wszystkie stanowiska we władzach pracowniczych organizacji zawodowych miały być obsadzane w drodze wyborów równych i tajnych. Wysokość składek członkowskich miała być określona statutem, z tym że Minister Pracy i Opieki Społecznej został upoważniony do ustalania górnego ich wymiaru ${ }^{99}$.

Przedstawione powyżej przepisy, a w szczególności rozróżnienie stowarzyszeń i związków zawodowych o zasadniczo odmiennych możliwościach działania i kompetencjach, sprzyjały uporządkowaniu struktury ruchu zawodowego. Równocześnie nie naruszały wolności związkowej, skoro zakładanie wszelkich organizacji zawodowych zostało uzależnione od inicjatywy osób zainteresowanych, a ustrój tych organizacji od statutu uchwalonego przez członków, oraz skoro nadzór nad ich działalnością miał być powierzony organom samorządu społeczno-gospodarczego, a o rozwiązaniu związku z urzędu mogły decydować jedynie sądy. Sprawy te nie wyczerpywały jednak problemów, jakie należało rozwiązać, aby doprowadzić do zespolenia ruchu zawodowego. Pozostawały jeszcze do rozstrzygnięcia problemy szczególnie trudne, dotyczące spraw ważnych i konfliktorodnych.

Pierwszy z nich polegał na ustaleniu zasad, według których miało być określane pole działania poszczególnych związków zawodowych. Dekret z 1919 r. ograniczył się, jak wiadomo, w tym względzie do sugerowania, aby związki miały charakter branżowy. Nowe projekty wypowiadały się w tej materii bardziej kategorycznie, stwierdzając, że „Związki zakłada się gałęziami pracy” ${ }^{100}$. Nie była to jednak zasada bezwzględnie wiążąca, gdyż projekt dekretu dopuszczał tworzenie związków także według zawodów, jeżeli „potrzeby i dążenia członków (danego) zawodu, na skutek jego właściwości, wiążą ich silniej ze sobą, niż ze

${ }^{97} \mathrm{~W}$ ramach poszczególnych związków miała działać ich odrębna reprezentacja (sekcja?); projekt 5, art. 37; projekt 4, art. 39 ust. 4; projekt 3, art. 39 ust. 2 i 3.

${ }^{98}$ Najwcześniejszy projekt przewidywał określenie tych spraw w samym tekście dekretu (projekt 1, art. 30). Naczelna Izba Pracy miała wydawać wzory statutów związkowych, niemające jednak mocy wiążącej; tak projekt 5, art. 36 ust.2; projekt 4, art. 39 ust. 2; projekt 3, art. 38 ust. 3.

${ }^{99}$ Projekt 5, art. 36-39; projekt 4, art. 40 i art. 31 ust. 2; projekt 3, art. 40 ust. 1 i art. 31 ust. 2.

${ }^{100}$ Projekt 5, art. 4 ust. 1; projekt 4, art. 3 ust. 1; projekt 3, art. 3 ust. 1. 
współpracownikami w obrębie [...] gałęzi pracy"101. Dopuszczono zatem przyjęcie jednej z tych dwóch powyższych zasad stosownie do uznania założycieli, co nie naruszało wolności związkowej, skoro trudno było wskazać inną alternatywę, a zakres terytorialny działania związków mógł być ustalany bez szczególnych rygorów ograniczających (nie mógł być tylko mniejszy niż obszar województwa).

Projekty nowego prawa nie ograniczały się jednak do tych ogólnych wskazówek, lecz zmierzały do wyczerpującego określenia samych gałęzi pracy i zawodów, „które można odrębnie organizować”, a więc które mogły stanowić domenę działania poszczególnych związków zawodowych. Ustalenie to miało być dokonane przez Ministra Pracy i Opieki Społecznej w drodze rozporządzenia ${ }^{102}$.

Była to regulacja narzucająca określony schemat organizacyjny, w ramach którego zakres działania poszczególnych związków musiał się pomieścić. Nie wyłączała ona wprawdzie możliwości tworzenia związków obejmujących więcej niż jedną gałąź pracy albo więcej niż jeden zawód, ale nie pozwalała na stosowanie w tej kwestii dowolnych kombinacji (np. obejmowania części jakiejś branży wraz z inną). Zakres działania związków musiał być, innymi słowy, wyznaczany pełnymi branżami czy też zawodami, zgodnie z ogólnie obowiązującą siatką na terenie całego kraju. Ograniczało to w pewnej mierze wolność zrzeszania się, nie pozwalając na wybór innych rozwiązań, uzasadnionych np. szczególnymi warunkami czy też tradycjami o charakterze lokalnym.

Dalsze problemy nasuwał stosunek wzajemny związków i zrzeszeń stanowiących najwyższy szczebel organizacyjny ruchu zawodowego. Zrzeszenia (według terminologii obiegowej $\mathrm{z}$ lat międzywojennych: centrale) stanowiły w stosunku do związków zawodowych organizację nadrzędną. Zgodnie z projektami nowego prawa miały kształtować ich ideologię i zawieranie układów zbiorowych pracy, a także sprawować nad nimi nadzór. Rola zrzeszeń była tym samym bardzo ważna, co przemawiało za rozciągnięciem ich wpływów na całość ruchu zawodowego. Przekonywających argumentów w tym względzie dostarczyła praktyka okresu międzywojennego, w którym działalność związków niezrzeszonych (tzw. dzikich) odgrywała, jak wyżej wskazano, ujemną rolę. Wyciągając stąd wnioski, uznano w projektach nowego prawa, że kategorię tych związków należy całkowicie wyeliminować. Zgodnie z tym postanowiono, że związek zawodowy „może istnieć i działać tylko w składzie stowarzyszenia"103.

Było to postanowienie o dużej doniosłości, służące niewątpliwie zespoleniu ruchu zawodowego, ale za cenę ograniczenia swobody zakładania związków. Jakkolwiek bowiem w Uzasadnieniu słusznie wskazywano, że prawie wszystkie istniejące u nas przed wojną związki niezrzeszone („dzikie”) skupiały bardzo

\footnotetext{
${ }^{101}$ Projekt 5, art. 4 ust. 2; ale podobnie projekt 4, art. 3 ust. 2 i projekt 3, art. 3 ust. 2.

${ }^{102}$ Projekt 5, art. 4 ust. 3; projekt 4, art. 3 ust. 3 i projekt 3, art. 3 ust. 3.

${ }^{103}$ We wszystkich trzech cytowanych wyżej projektach: art. 2 ust. 2.
} 
małą liczbę członków ${ }^{104}$, to jednak całkowite zablokowanie inicjatyw zakładania związków, nieakceptujących ideologii czy też form działania istniejących zrzeszeń, mogło budzić wątpliwości.

Co do znacznej większości organizacji małych i słabych można było wprawdzie uznać, że nie zasługują one na status związku i mogą być zredukowane do poziomu stowarzyszeń zawodowych działających na wyżej podanych zasadach ${ }^{105}$. Nieliczne silniejsze związki tej kategorii ${ }^{106}$ nie mogły być jednak w ten sposób potraktowane. Trzeba tu było szukać innych rozwiązań i to raczej w formie pośredniego oddziaływania aniżeli regulacji prawnej ${ }^{107}$.

Najtrudniejszy problem do rozwiązania powstawał jednak na szczeblu centralnym: zrzeszeń (central) ruchu zawodowego. Chodziło bowiem nie tylko o to, aby zrzeszenia obejmowały swym zasięgiem działania wszystkie związki zawodowe, lecz także o to, aby liczba samych zrzeszeń nie była nadmierna. Doświadczenia okresu międzywojennego stanowiły w tym względzie wymowną przestrogę. Rozbicie ruchu zawodowego pomiędzy różne kierunki i orientacje ideologiczne oraz ośrodki wpływów przyczyniło się bowiem wówczas w nie mniejszym, a raczej w znacznie większym stopniu do osłabienia jego pozycji i prestiżu, co rozproszenie sił pomiędzy nazbyt liczne, i w znacznej części słabe, organizacje związkowe.

Postulat większego zespolenia ruchu zawodowego jako całości, na szczeblu centralnym, nabierał tym samym szczególnego znaczenia. Departament Pracy i Opieki Społecznej zajął w tej sprawie stanowisko w różnych dokumentach. W ostatnim sprawozdaniu wysłanym do Londynu wypowiedział się za scaleniem ruchu zawodowego przez ograniczenie głównych jego nurtów do dwóch, a co najwyżej trzech ${ }^{108}$. W tekście Uzasadnienia wyraził podobny pogląd, afirmując racje bytu 3 zrzeszeń ${ }^{109}$.

Konfrontując to stanowisko $\mathrm{z}$ realiami okresu międzywojennego, można by stwierdzić, że Departament skłonny był zaakceptować powołanie na nowo do życia central odpowiadających trzem dawnym kierunkom ruchu zawodowego o największych wpływach, reprezentujących związki klasowe, tzw.

104 Jak podano w Uzasadnieniu (s. 3), mniej niż 1200 członków, a niektóre nawet tylko kilkudziesięciu, w jednym przypadku tylko kilkunastu (sic!).

${ }^{105}$ Taką propozycję wysuwał J.G. Wengierow (op. cit., s. 212), który mówił o przerzuceniu związków dzikich „na formy stowarzyszeniowe”. Projekt 5 postanawiał, że związek zawodowy występujący ze zrzeszenia i nieprzystępujący do innego staje się po 6 miesiącach stowarzyszeniem zawodowym (art. 34 ust. 3).

${ }^{106}$ Należało do nich Stowarzyszenie Nauczycieli Chrześcijańsko-Narodowych, które liczyło ponad 11000 członków (Uzasadnienie, s. 3).

${ }^{107}$ J.G. Wengierow, op. cit., s. 214. Dotyczyło to tym bardziej zespolenia samych zrzeszeń (central) ruchu zawodowego, a więc kolejnego wątku naszych rozważań.

${ }^{108}$ Sprawozdanie z działalności Departamentu..., s. 2-3.

${ }^{109}$ Uzasadnienie, s. 11. 
polskie i chrześcijańskie. Nie widział już natomiast miejsca dla dawnego Związku Związków Zawodowych, o czym decydowała niewątpliwie jego sanacyjna proweniencja i „rozbijacka” funkcja, pomimo znaczącej ewolucji, jaką ruch ten przeszedł w ostatnich latach przed wojną. Nie uznano również celowości odtwarzania innych central o znacznie mniejszym zakresie wpływów.

Nie wystarczało jednak samo określenie docelowej struktury ruchu zawodowego na szczeblu centralnym (a także w odniesieniu do podstawowych jego ogniw: związków i stowarzyszeń). Trzeba było również wskazać drogi prowadzące do osiągnięcia postulowanego stanu rzeczy, a w szczególności dokonać wyboru zasad działania i technik prawnych służących temu celowi.

Najogólniej rzecz biorąc, były w tym zakresie dwie możliwości. Jedna z nich polegała na stopniowej budowie nowej struktury ruchu zawodowego od podstaw, poczynając od organizacji najniższego szczebla. Taki tryb postępowania zdawał się wskazywać przepis zawarty w jednym z najwcześniejszych projektów, stwierdzający, że „od stowarzyszenia pracowniczego rozpoczyna się rozwój pracowniczego związku zawodowego" "110. Po tej też linii poszły postanowienia zawarte w późniejszych, najbardziej dojrzałych projektach, według których związki zawodowe, a także zrzeszenia miały powstawać w drodze fuzji stowarzyszeń, mogących wykazać się określonym składem członkowskim ${ }^{111}$.

Treści tych przepisów nie można jednak interpretować w tym sensie, jakoby miała to być jedyna droga prowadząca do powstawania organizacji zawodowych wyższego szczebla, a w szczególności zrzeszeń. Nic nie upoważniało bowiem do uznania sceny związkowej po ustaniu okupacji za tabula rasa, która dopiero stopniowo, po upływie pewnego czasu, miałaby być zabudowana przez organizacje wyższego szczebla: silniejsze związki i centrale związkowe ${ }^{112}$. Wszystko wskazuje na to, że wspomniane wyżej przepisy regulowały tylko jedną z dróg postępowania, która miała mieć zastosowanie w przyszłości w ruchu związkowym, służąc jego dalszej konsolidacji w miarę wzrostu i umacniania się pozycji stowarzyszeń i pomniejszych związków ${ }^{113}$.

Podstawowe znaczenie z omawianego punktu widzenia miała inna alternatywa, polegająca na tym, aby przyjąć za punkt wyjścia stan, jaki ukształtuje się bezpośrednio po ustaniu okupacji i ujawnieniu się struktur związkowych zdolnych do działania, a następnie dążyć do ukształtowania go zgodnie z postulowanym modelem organizacyjnym. Takie rozwiązanie zostało też przyjęte w najbardziej dojrzałych projektach nowego prawa związkowego.

\footnotetext{
${ }^{110}$ Projekt 2, art. 1 ust. 3.

${ }^{111}$ Projekt 3 i 4, ten sam art. 36-37. W projekcie 5 treść tych przepisów uległa zatarciu.

112 Metoda ta, która znalazła, jak wiadomo, zastosowanie w PRL w 1982 r., nie miała żadnych szans w odniesieniu do tamtego okresu i nie mogła tym samym być brana poważnie pod uwagę.

${ }^{113}$ Przekonuje o tym fakt, że w tych samych projektach były zawarte przepisy dotyczące zasad odtwarzania ruchu zawodowego w okresie przejściowym, o czym niżej.
} 
Istotna jego treść sprowadzała się do określenia terminu, w ciągu którego wszystkie zgłaszające się organizacje miałyby być rejestrowane jako pełnoprawne związki, oraz do pozostawienia im następnie pewnego czasu na dostosowanie ich struktur do wymogów nowego prawa. Regulacja ta miała dotyczyć wszystkich organizacji zawodowych, a więc stowarzyszeń, związków oraz zrzeszeń, przy czym wyznaczono im 12-miesięczny okres dla rejestracji i dalszy także 12-miesięczny dla dopełnienia wymagań wynikających z nowych przepisów; w razie ich niedopełnienia w tym czasie miał wygasać dokonany uprzednio wpis tych organizacji do rejestru, co przesądzało negatywnie o ich dalszym istnieniu ${ }^{114}$.

Regulacja ta miała, jak zaznaczono, dotyczyć także zrzeszeń (central) ruchu zawodowego, nie przesądzała jednak sama przez się ich maksymalnej liczby. Do sprawy tej odnosił się natomiast odrębny przepis, zawarty w jednym z projektów, który postanawiał, że zarejestrowane mogą być w terminie do 12 miesięcy od daty wejścia w życie nowego prawa, nie więcej niż trzy zrzeszenia pracowniczych związków zawodowych ${ }^{115}$. Przepis ten nie został jednak powtórzony w następnym projekcie (D. 2), uznanym przez nas za najbardziej dojrzały. Świadczy to o wahaniach w ostatecznym przyjęciu tej regulacji, której rygoryzm zwiększało przewidywane w niej przekazanie majątku zrzeszeń, którym odmówiono by rejestracji, zrzeszeniom mającym nadal prawo obywatelstwa ${ }^{116}$.

Oceniając ostatecznie projekty Departamentu Pracy i Opieki Społecznej w kwestii ograniczenia liczby zrzeszeń zawodowych, trzeba mieć na uwadze nie tylko kierunek ich ewolucji, lecz również fakt, że nawet projekt najbardziej dojrzały nie był projektem ostatecznym, akceptowanym w pełni przez Departament. Całość regulacji zawartej w tych projektach (łącznie z ostatnim) należy zatem traktować raczej jako wyraz poszukiwania najwłaściwszych rozwiązań legislacyjnych, aniżeli jako produkt myśli wyrażającej ukształtowane już całkowicie stanowisko Departamentu. Niewątpliwe było jego zaangażowanie na rzecz wydatnego ograniczenia liczby zrzeszeń związkowych i to w zasadzie do trzech, a także przekonanie, że zmiana ta powinna znaleźć oparcie w przepisach prawnych.

Pozostawała natomiast w znacznej mierze otwarta sprawa określenia techniki prawnej, służącej najlepiej temu celowi, a także znalezienia dla niej skutecznego poparcia w pozaprawnych środkach oddziaływania. Nie ulegało bowiem wątpliwości, że sprawa tak delikatna, jak ograniczenie czy zmodyfikowanie wpływu różnych ośrodków politycznych na ruch zawodowy (a wpływ ten rozstrzygał przecież w ogromnej mierze o tworzeniu odrębnych zrzeszeń), musi być

114 Projekt 5, art. 47; projekt 4, art. 45. Przepisy te przewidywały przekazanie majątku tych organizacji - związkom nadal działającym. W projekcie 3 brak było natomiast przepisów przejściowych, regulujących te sprawy.

115 Projekt 4, art. 45 ust. 2.

${ }_{116}$ Najbardziej rygorystyczne postanowienia w tej materii zawarte były w Tezach (pkt 14) oraz w projekcie 2, art. 59. W późniejszych projektach nie znajdujemy już ich odpowiednika. 
rozwiązywana przy użyciu różnych środków nacisku, perswazji i zachęty, które bywają często nieporównanie bardziej skuteczne niż nakaz ustawowy ${ }^{117}$. Projekty opracowane przez Departament nie zamykały tej sprawy, lecz określały słusznie kierunek pożądanych zmian i posuwały wydatnie naprzód poszukiwanie właściwych metod działania.

Zamykając na tym przegląd najważniejszych problemów dotyczących struktury ruchu zawodowego, trzeba jeszcze poświęcić nieco uwagi niektórym kwestiom z nimi związanym.

Jedną z nich był usankcjonowany przepisami dekretu obowiązek współdziałania ze sobą związków o tym samym zakresie działania, ale różnej przynależności zrzeszeniowej. $Z$ przedstawionych wyżej przepisów wynikało, że projektowany dekret dopuszczał ,pluralizm” związkowy, mogły więc istnieć na terenie tej samej gałęzi związki należące do różnych zrzeszeń i reprezentujące tym samym różny kierunek ideologiczny ${ }^{118}$. Stosunek wzajemny takich związków określały przepisy dekretu zgrupowane w rozdziale noszącym tytuł Równe możliwości dziatania pracowniczych organizacji zawodowych. Treść tych przepisów sprowadzała się do obowiązku wzajemnej informacji o podejmowanych wystąpieniach wobec pracodawców i rokowaniach układowych oraz dopuszczania do wspólnych obrad i zajmowania w danej sprawie stanowiska. Obowiązek ten miał służyć koordynowaniu działalności związków o różnej orientacji i zapobiegać nielojalnej konkurencji pomiędzy nimi. Dotyczył, na równi z poszczególnymi związkami, zrzeszeń związków w ich stosunkach wzajemnych ${ }^{119}$.

Wyrazem tej samej myśli był zakaz selektywnego traktowania związków zawodowych przez władze państwowe i samorządowe. Władze te zobowiązano - w przypadku podejmowania spraw wymagających kontaktowania się z ruchem zawodowym - do współdziałania ze wszystkimi związkami danej gałęzi pracy i na danym obszarze (i odpowiednio ze wszystkimi zrzeszeniami, jeśli charakter sprawy wymagał współdziałania na tym szczeblu) ${ }^{120}$.

Charakter stosunków wzajemnych między organizacjami zrzeszającymi pracowników i pracodawców określał natomiast wzajemny obowiązek „stanięcia do rokowań" na żądanie strony przeciwnej ${ }^{121}$. Żadna z tych stron nie mogła tym samym uchylić się od próby rozwiązania spraw spornych w drodze porozumienia. Strajki, bojkoty i inne tego rodzaju akcje mogły natomiast być podejmowane tylko z inicjatywy związku zawodowego i pod warunkiem prowadzenia ich pod jego kierownictwem. Nie wyłączało to natomiast, w przypadku konfliktów o szerszym

${ }^{117} \mathrm{~W}$ tym sensie wypowiadał się przed wojną J.G. Wengierow, op. cit., s. 214.

${ }^{118}$ Nie mogły one natomiast dublować się w tym samym zrzeszeniu (projekt 5, art. 32 ust. 1). Każde zrzeszenie miało skupiać całość jednego kierunku ruchu zawodowego (ibidem, art. 2 ust. 1).

${ }_{119}$ Projekt 5, art. 21; projekt 4, art. 21; projekt 3, art. 23.

${ }^{120}$ Projekt 5, art. 20; projekt 4, art. 20; projekt 3, art. 22.

${ }^{121}$ Projekt 5, art. 8 ust. 3; projekt 4, art. 10 ust. 3; projekt 3, art. 10 ust. 3. 
zasięgu, możliwości powołania międzyzwiązkowej komisji kierującej o zakresie działania obejmującym określoną gałąź pracy na danym obszarze ${ }^{122}$.

Na uwagę zasługuje sytuacja prawna pracowników niezrzeszonych w żadnym związku zawodowym. Osoby te, nie włączając się organizacyjnie do ruchu zawodowego, odnosiły pośrednio korzyści z jego działalności, gdyż związki działały, jak już stwierdzono, również w ich imieniu, a zwierane przez nie układy zbiorowe pracy miały także w stosunku do nich moc obowiązującą. Okoliczność ta bywa często podnoszona jako uzasadniająca nałożenie na pracowników niezrzeszonych pewnych świadczeń. Projektowany dekret poszedł po tej linii, wprowadzając tzw. zastępczą składkę związkową, uiszczaną właściwej izbie pracy w wysokości przez nią ustalonej i przeznaczoną na cele oświatowo-kulturalne pracowników ${ }^{123}$.

Związki zawodowe zostały, jak wiadomo, podporządkowane izbom pracy jako organom samorządu społeczno-gospodarczego w zakresie obowiązku składania sprawozdań, protokółów walnych zebrań itp. Zostały one także zobowiązane do współdziałania, nie tylko z izbami, lecz również z władzami państwowymi i samorządowymi przy opracowywaniu i wcielaniu w życie planów gospodarczych. Odpowiadało temu prawo występowania wobec tych czynników z inicjatywami i opiniami, dotyczącymi polityki społecznej i gospodarczej oraz regulacji prawnej, ze szczególnym uwzględnieniem podnoszenia stanu bezpieczeństwa, higieny i kultury pracy ${ }^{124}$.

Rozwiązanie związku zawodowego zostało zastrzeżone do wyłącznej właściwości sądów. Natomiast rozwiązanie zrzeszenia mogło także nastąpić w razie znacznego zmniejszenia się zakresu jego działania ${ }^{125}$. Tylko sąd został również upoważniony do nakładania na organizacje zawodowe i osoby działające $\mathrm{w}$ ich imieniu innych kar (grzywny, nagany, złożenia z urzędu) za działania niezgodne z prawem ${ }^{126}$.

\section{Izby pracy}

Izby Pracy stanowiły w koncepcji Departamentu Pracy i Opieki Społecznej niezmiernie ważny element postulowanego ustroju pracy, decydujący o jego pełnym rozwinięciu i ugruntowaniu. Zamierzona konsolidacja związków zawodowych, połączona z rozszerzeniem zakresu ich zadań pozwalała wprawdzie oczekiwać, że staną się one mocnym ogniwem tego ustroju. $Z$ różnych względów uważano jednak, że ta ważna reforma nie będzie sama przez się wystarczająca.

\footnotetext{
${ }^{122}$ Projekt 5, art. 9 ust. 1 i 2; projekt 4, art. 11 ust. 1 i 2; projekt 3, art. 11 ust. 1 i 2.

${ }^{123}$ Projekt 5, art. 27; projekt 4, art. 26; projekt 3, art. 28.

${ }^{124}$ Projekt 5, art. 12; projekt 4, art. 12 ust. 3 (krótsze ujęcie); podobnie projekt 3, art. 13 ust 2.

${ }^{125}$ Projekt 5, art. 35; projekt 4, art. 43; projekt 3, art. 43.

${ }^{126} \mathrm{~W}$ projekcie 5 przepisy karne zostały wyodrębnione w osobny dział (art. 43-46).
} 
Przede wszystkim należało się liczyć z faktem, że pomimo wszelkich działań konsolidacyjnych ruch zawodowy pozostanie jednak w przyszłości podzielony najprawdopodobniej na trzy kierunki ideologiczne i odpowiadające im zrzeszenia. Doprowadzenie do takiego stanu byłoby i tak znacznym osiągnięciem w porównaniu $\mathrm{z}$ daleko idącym rozbiciem ruchu zawodowego w okresie międzywojennym, niemniej jednak oznaczało, że ogół pracowniczy nie będzie miał w związkach zawodowych jednolitej reprezentacji.

Poza tym z samego charakteru związków zawodowych jako organizacji zajmujących się szerokim zakresem spraw pracowniczych w przekroju branżowym, zawodowym i lokalnym wynikać musiała trudność skupienia przez nie dostatecznej uwagi na kwestiach o kluczowym znaczeniu dla rozwoju społeczno-gospodarczego kraju i kształtowania w nim pozycji całego świata pracy. I wreszcie, pomimo wszelkich postulowanych zmian w określaniu zadań związków zawodowych, było rzeczą jasną, że będą one, jako nosiciel interesów klasowych pracowników, z konieczności uwikłane w sprzeczności interesów, konflikty i zatargi zbiorowe, niezbędne dla wywalczania bieżących korzyści. Trudno było w tych warunkach oczekiwać pełniejszego zaangażowania się tych organizacji w konstruktywne współdziałanie na rzecz rozwiązywania ogólniejszych problemów, warunkujących rozwój gospodarczy kraju.

Izby pracy zostały pomyślane jako instytucja dopełniająca rolę ruchu zawodowego w trzech wskazanych kierunkach: miały mianowicie (1) reprezentować świat pracy jako całość, (2) skupić główną uwagę na sprawach decydujących o wszechstronnym rozwoju gospodarstwa społecznego i (3) uczestniczyć w ich konstruktywnym kształtowaniu. Trudność bliższego określenia struktury, pozycji i zadań izb pracy wynikała natomiast stąd, że miała to być instytucja nowa, bez precedensu w przedwojennym porządku prawnym.

Konstytucja marcowa z 1921 r. stwarzała wprawdzie w tym względzie szerokie ramy prawne, przewidując, że „osobna ustawa powoła samorząd gospodarczy dla poszczególnych dziedzin życia gospodarczego, a mianowicie izby rolnicze, handlowe, przemysłowe, rzemieślnicze, pracy najemnej i inne, połączone w Naczelną Izbę Gospodarczą" (art. 68). W treści tej znalazła tym samym wyraz, bliska koncepcjom Departamentu Pracy i Opieki Społecznej, szeroko pojęta idea stworzenia samorządu gospodarczego z izbami pracy jako jego organiczną częścią.

Postanowienia te nie znalazły jednak dobrego przyjęcia w opinii społecznej $^{127}$ i pozostały przez dłuższy czas martwą literą. Dopiero w latach 1927-1928

${ }^{127}$ M. Święcicki (op. cit., s. 318), oceniając w swej publikacji z roku 1960 ówczesny odbiór instytucji samorządu gospodarczego, zaliczył ją do „ustrojowych nowalijek”, o której nikt na dobrą sprawę nie wiedział, do czego też mogłaby służyć. Przytaczał też opinię posła Niedziałkowskiego o „przypadkowości całego art. 68 Konstytucji”. Por. także W.L. Jaworski, Ankieta o Konstytucji, Warszawa 1924, s. 173 i n. 
przystąpiono do ich wcielania w życie od strony zainteresowań sfer gospodarczych, powołując kolejno: izby rzemieślnicze (1927), izby przemysłowo-handlowe (1927) i izby rolnicze (1928), których ocena kształtowała się kontrowersyjnie ${ }^{128}$. Utworzenie tych instytucji wywołało poczucie braku równowagi na niekorzyść świata pracy, który pozbawiony był nadal możliwości instytucjonalnego wpływania na treść ustawodawstwa, jakie uzyskały sfery gospodarcze reprezentowane we wspomnianych wyżej izbach.

$\mathrm{Na}$ tym tle nasiliły się postulaty powołania do życia izb pracy, co znalazło odbicie w obfitym piśmiennictwie poświęconym tej sprawie, nawiązującym do doświadczeń obcych, w szczególności do instytucji izb utworzonych w $1920 \mathrm{r}$. w Austrii. Do najbardziej znaczących należały publikacje W. Landaua, który postulat utworzenia izb pracy wiązał z ideą planowości i daleko idącej demokracji gospodarczej ${ }^{129}$; J. Hoppego, który rozwijał ideę uspołecznienia państwa i samorządu gospodarczo-zawodowego jako „naturalnego dziedzica” wielu jego funk$\mathrm{cji}^{130}$. Inny autor $-\mathrm{H}$. Rygier ${ }^{131}$ opublikował projekt ustawy o izbach pracy stanowiący „W znacznej części powtórzenie lub przerobienie odpowiedniego projektu Ministerstwa [Pracy i Opieki Społecznej]"132, dodając do niego obszerne uzasadnienie. Godny uwagi był wreszcie starannie wyważony głos J.G. Wengierowa, w którym znalazły wyraz różne oryginalne, jakkolwiek dyskusyjne koncepcje ${ }^{133}$.

W późniejszych latach trzydziestych zmienił się charakter kontrowersji wokół sprawy izb pracy. Przedmiotem sporu stało się odtąd nie tyle samo utworzenie tych izb, co sposób ich powoływania oraz ich struktura i kompetencje. Ogólny klimat polityczny w kraju, nacechowany dążeniem ówczesnej władzy do umocnienia autorytatywnych form rządzenia, wycisnął swe piętno na treści projektów przygotowywanych przez ówczesne Ministerstwo Opieki Społecznej. Zarysowała się na tym tle zasadnicza kontrowersja wokół stosunku planowanych izb pracy do ruchu zawodowego.

Chodziło bowiem o to, czy izby pracy staną się emanacją związków zawodowych i będą się przyczyniały do umacniania ich pozycji, czy też upodobnią się, pod przykrywką samorządu, do organów administracyjnych nadzorujących i krępujących ich działalność. W projektach rządowych z lat 1936 i 1937 widziano

${ }^{128}$ R. Rybarski (Program gospodarczy, Warszawa 1932, s. 46) stwierdzał, że są to instytucje kosztowne, które nie zmniejszają w istocie zadań państwowej administracji gospodarczej i z którymi administracja ta się nie liczy.

${ }^{129}$ L. Krzywicki w przedmowie do książki W. Landaua (Izby Pracy, Warszawa 1932) wypowiadał się za potrzebą powołania izb pracy, nie przeceniał jednak ich doniosłości i wpływów, widząc w nich instytucje „o skromnych zadaniach i jeszcze skromniejszych środkach podołania tym skromnym zadaniom" (ibidem, s. 6).

${ }^{130}$ J. Hoppe, Samorząd pracy, Warszawa 1932, s. 6.

${ }^{131}$ H. Rygier, Izby Pracy. Projekt ustawy i uzasadnienia, Warszawa 1932.

132 Taką opinię wypowiedział J.G. Wengierow, Izby Pracownicze, Warszawa 1934, s. 3.

${ }^{133}$ Ibidem. 
przejaw tych ostatnich tendencji, co przesądziło o negatywnym stosunku do nich wszystkich liczących się central związkowych, łącznie z powstałymi z inicjatywy sfer sanacyjnych. Z ich krytyczną oceną spotykały się ogólne założenia przygotowywanych projektów oraz zawarte w nich rozwiązania prawne, dotyczące spraw $\mathrm{z}$ tego punktu widzenia kluczowych, takich jak: struktura, skład, organizacja wewnętrzna i zadania izb pracy ${ }^{134}$.

Ostatecznie żaden projekt nie uzyskał oficjalnej akceptacji i nie stał się prawem. Spuścizną okresu międzywojennego pozostały zatem same zamierzenia i rozgorzałe wokół nich kontrowersje, które żyły nadal w świadomości ludzi opracowujących i oceniających w latach wojny nowe założenia programowe. Z okolicznością tą należało się liczyć, podejmując inicjatywę utworzenia izb pracy w przyszłej Polsce.

Departament Pracy i Opieki Społecznej poświęcił tej sprawie wiele uwagi, jednakże jedyną jego wypowiedzią skierowaną oficjalnie na zewnątrz były tezy dotyczące izb pracy, wysłane jako załącznik do sprawozdania za II kwartał 1944 r. do Londynu ${ }^{135}$. Projekt samego prawa o izbach pracy zachował się natomiast w kilku wersjach, z których żadna nie uzyskała ostatecznej akceptacji i których kolejność powstawania nie do końca da się niespornie ustalić' ${ }^{136}$. Zachowało się poza tym opracowanie problemowe, określone jako wstępne i dyskusyjne ${ }^{137}$, oraz różne materiały dotyczące izb pracy w kontekście szerszej problematyki ustroju społeczno-gospodarczego.

Mamy zatem do czynienia z sytuacją podobną jak w przypadku związków zawodowych, gdzie projekt noszący cechy najbardziej dojrzałego nie mógł być uznany do końca za jedynie miarodajny. W przypadku izb pracy także nie możemy oprzeć się wyłącznie na projekcie wymienionym w przypisie 136 na ostatnim miejscu, lecz będziemy musieli sięgać w pewnych sprawach do innych, zwłaszcza dwóch poprzednich, aby lepiej wydobyć myśl programową Departamentu, która przewija się przez wszystkie te opracowania, nie znajdując w żadnym z nich wyłącznie miarodajnego wyrazu. Całość tych opracowań daje natomiast obraz nie tylko głównych idei przewodnich, lecz także stopniowego krystalizowania się poglądów Departamentu, jakkolwiek nie było mu dane wypowiedzieć swego „ostatniego słowa”. Tekst projektów wymaga poza tym konfrontowania z Tezami, które ograniczają się jednak do sygnalizowania spraw najbardziej zasadniczych.

${ }^{134}$ M. Święcicki, op. cit., s. 320-324.

${ }^{135}$ Izby Pracy, zał. 3. Cytowane dalej jako Tezy IP.

${ }^{136}$ Są to następujące projekty: (1) Prawo izb pracy (maszynopis, s. 11, zbiory rodziny M. Święcickiego); (2) Prawo o izbach pracy (maszynopis, s. 10, zbiory rodziny M. Święcickiego); (3) Prawo izb pracy (maszynopis, gęsto zapisany, s. 6, zbiory W.S. oraz AAN, KC PZPR 203/VII-35, t. 2, k. 209-214); (4) Prawo o izbach pracy (red. D. 1, s. 9, AAN, KC PZPR 203/VII, t. 2, k. 157-165); (5) Prawo o izbach pracy (red. D. 2, s. 8, AAN, KC PZPR 203/VII-35, t. 2, k. 133-140). Miarodajne są przede wszystkim projekty 3,4 i 5 .

${ }^{137}$ Izby Pracy (sformułowania wstępne dyskusyjne), AAN, KC PZPR 203/VII-35, t. 2, k. 191-197. 
Podstawową kwestię stanowi oczywiście charakter prawny izb pracy i zakres ich zadań. Co do pierwszej kwestii zarówno Tezy, jak i projekty opracowane przez Departament wypowiadają się niedwuznacznie, stwierdzając, że izby pracy są osobami prawa publicznego, obejmującymi w charakterze członków wszystkich pracowników, zarówno pozostających w umownym, jak i służbowym stosunku pracy, a także osoby znajdujące się w zbliżonej sytuacji społecznej (jak: chałupnicy, członkowie spółdzielni pracy) ${ }^{138}$. Osoby te stają się członkami izb pracy ex lege i są obowiązane do opłacania składek na ich rzecz ${ }^{139}$. Izby są organami samorządu pracy, powoływanymi i pozostającymi pod nadzorem Ministra Pracy ${ }^{140}$. Przewidziano utworzenie Centralnej Izby Pracy oraz izb wojewódzkich (mogących również obejmować większy obszar niż województwo, ale tak, aby wszędzie stanowiły one odpowiednik innych organów samorządu gospodarczego, jak izby przemysłowo-handlowe $\mathrm{i}$ in. $)^{141}$.

Postanowienia te nie mogły wzbudzać kontrowersji, poza dwustopniową strukturą izb pracy. W okresie międzywojennym środowiska związkowe wypowiadały się zdecydowanie za powołaniem wyłącznie jednej Izby Pracy o zasięgu ogólnokrajowym, obawiając się w przypadku tworzenia jej terytorialnych odpowiedników nadmiernej rozbudowy aparatu administracyjnego izb pracy, mogącej zdominować ruch zawodowy ${ }^{142}$. Odmienne stanowisko Departamentu Pracy i Opieki Społecznej zostało podyktowane przeświadczeniem, że instytucja działająca wyłącznie na szczeblu ogólnokrajowym nie będzie mogła sprostać wyznaczonej jej roli w zakresie tworzenia nowego ustroju pracy i porządku społecznogospodarczego. Punkt ciężkości problemu przesuwał się zatem na płaszczyznę owej roli i wynikających z niej zadań, jakimi zamierzano obciążyć izby pracy. Na tej sprawie wypada zatem skupić naszą szczególną uwagę.

Zarówno tezy, jak i projekt nakładają na izby pracy zadania bardzo liczne, o różnym charakterze i znaczeniu dla życia społeczno-gospodarczego, a przy tym sformułowane z różnym stopniem szczegółowości, co w sumie składa się na regulację złożoną i niezbyt przejrzystą ${ }^{143}$. Aby przedstawić w uporządkowany sposób tę materię, trzeba rozważyć trzy podstawowe zakresy zadań izb pracy i związane $\mathrm{z}$ nimi problemy.

Pierwszy z tych zakresów wiąże się z uznaniem izb pracy za „urzędową reprezentację ogółu pracowników"144. Działaniu w tym charakterze służy przyzna-

${ }^{138}$ Tezy IP, pkt 2. Projekt 5, art. 2 ust. 1, art. 3 ust. 2 i 3; projekt 4, art. 3 ust. 1, art. 4; projekt 3 , art. 3 i 4.

${ }^{139}$ Projekt 5, art. 3 ust. 1, art. 22 ust. 1 pkt 1; projekt 4, art. 30 ust. 1 pkt 1; projekt 3, art. 29 ust. 1 pkt 1 . Składki miały być nie wyższe niż 5\% płacy. Por. także Tezy IP, pkt 12.

${ }^{140}$ Projekt 5, art. 1 ust. 1, art. 2 ust. 2, art. 24; projekt 4, art. 2 ust. 2, art. 32. Tezy IP, pkt 2, 4, 13.

${ }^{141}$ Projekt 5, art. 1 ust. 1, art. 2 ust. 2 i 3; projekt 4, art. 2 ust. 2 i 3 . Tezy IP, pkt 4.

${ }^{142}$ M. Święcicki, op. cit., s. 323.

${ }^{143}$ Tezy IP, pkt 9: wyliczenie zadań od (a) do (m) projekt 5, art. 4-12; projekt 4, art. 5-21.

${ }^{144}$ Projekt 5, art. 5 ust. 1. 
nie izbom pracy „prawa pośredniej inicjatywy ustawodawczej” ${ }^{145}$, polegającej na przedstawianiu Rządowi za pośrednictwem Ministra Pracy i Opieki Społecznej projektów prawa dotyczącego indywidualnych i zbiorowych stosunków pracy, a także sądów pracy, rad zakładowych i związków zawodowych, służby zdrowia, ubezpieczeń społecznych oraz urządzeń gospodarczych bezpośrednio związanych z potrzebami pracowników. W przypadku przedstawienia projektów przez Naczelną Izbę Pracy (i wszystkie izby wojewódzkie), Rząd powinien zaopatrzyć je swoją opinią i przedłożyć władzy ustawodawczej bądź też umotywować swą odmowną decyzję. Projekt zastrzegał ponadto, że żadna ustawa $\mathrm{z}$ wymienionego wyżej zakresu nie może być uchwalona bez uprzedniego zasięgnięcia opinii izb pracy ${ }^{146}$.

Do tej samej grupy zadań należy delegowanie przez izby pracy przedstawicieli pracowników we wszystkich przypadkach, w których prawo przewiduje ich udział w organach kolegialnych, a także wyznaczanie biegłych i rzeczoznawców w zakresie zagadnień pracy, życia zawodowego i innych spraw społeczno-gospodarczych ${ }^{147}$. Należy również do tej kategorii zbieranie i przekazywanie władzom państwowym materiałów, obrazujących dążenia i potrzeby pracowników oraz prowadzenie i popieranie w tym celu badań naukowych ${ }^{148}$.

Interesom ogółu pracowników miało też służyć rozwijanie i popieranie przez izby pracy rozległej działalności samopomocowej w zakresie szkolnictwa zawodowego, kultury i oświaty, zatrudnienia, osiedli pracowniczych i organizacji wczasów, poradnictwa prawnego i pomocy prawnej, opieki społecznej, służby zdrowia, organizowania oszczędności pracowniczej i w innych dziedzinach, przy czym zastrzeżono co do zasady odpłatność wszelkich świadczeń objętych tą $\operatorname{akcją~}{ }^{149}$.

Drugi, niezmiernie istotny zakres zadań izb pracy polegał na szeroko zakrojonym współdziałaniu z władzami państwowymi, samorządem terytorialnym oraz innymi organami (izbami) samorządu gospodarczego. Zadania te zostały zasygnalizowane w Tezach ${ }^{150}$, a następnie znacznie szerzej rozwinięte w projektach prawa (D. 1 i D. 2). Miało to być w szczególności współdziałanie w opracowywaniu planów gospodarki narodowej i w ich wykonywaniu, w prowadzeniu polityki zatrudnienia mającej na celu likwidację bezrobocia, ale również „zjawisk życia bez pracy oraz zajęć szkodliwych społecznie”, w doskonaleniu ubezpieczeń społecznych, służby zdrowia oraz pomocy i opieki

\footnotetext{
${ }^{145}$ Projekt 4, art. 6 ust. 1; podobnie projekt 3, art. 6 ust. 1 .

${ }^{146}$ Projekt 4, art. 6 ust. 2-5; podobnie projekt 3, art. 6 ust. 2-4. Izby zostały także zobowiązane do obserwowania sposobu wykonywania ustaw i występowania do najwyższych instancji sądowych o ustalenie ich wykładni (projekt 5, art. 4 ust. 3; projekt 4 art. 8).

${ }^{147}$ Projekt 5, art. 5 ust. 5 i 6; projekt 4, art. 8.

${ }^{148}$ Projekt 5, art. 9 ust. 1 i 2; projekt 4, art. 13.

${ }^{149}$ Projekt 5, art. 6; projekt 4, art. 14; projekt 3, art. 13.

${ }^{150}$ Tezy IP, pkt 9a.
} 
społecznej, a także w kształtowaniu ustroju szkolnictwa podstawowego i zawodowego oraz programów nauczania ${ }^{151}$.

Był to zatem zakres szeroki, a przy tym niewyczerpujący, bo objęty ogólną klauzulą współdziałania w urządzaniu spraw (stosunków) społecznych i gospodarczych, w ramach której wymienione zadania wskazano jako ważne (,w szczególności”). Co więcej, współdziałanie, o którym mowa, miało się wyrażać nie tylko w przedstawianiu opinii, wniosków i projektów do właściwych władz i uczestniczeniu we wspólnych naradach, lecz także w przejmowaniu po części ich roli. Izby pracy mogły bowiem również przejmować pewne działy administracji państwowej lub niektóre ich funkcje ${ }^{152}$. Tak znaczne rozbudowanie tej kategorii zadań mogło budzić wątpliwości co do ich zgodności z charakterem izb pracy, a także co do możliwości pogodzenia z rolą izb jako „reprezentacji pracowników”.

$\mathrm{Na}$ tym tle szczególnej wagi nabierał trzeci dział zadań i kompetencji izb pracy, określający ich stosunek do ruchu zawodowego. Była to, jak już wskazano, sprawa o znaczeniu newralgicznym, od której prawidłowego rozstrzygnięcia zależała akceptacja samej instytucji izb pracy przez zorganizowane kręgi pracownicze. Wskazane wyżej zamierzenia szerokiej rozbudowy zadań izb pracy zwiększały jeszcze jej znaczenie. Źródło trudności leżało jednak w samym charakterze tej instytucji, która miała zwiększać możliwości działania i wpływy zorganizowanego świata pracy, a równocześnie służyć umocnieniu jedności w jego szeregach. Szczególny kontekst dla obu tych ról stwarzało przy tym dążenie do podporządkowania procesów społeczno-gospodarczych rygorom planowości.

Wszystkie te problemy i trudności znalazły odbicie w sformułowaniach programowych Departamentu Pracy i Opieki Społecznej. Świadczy o tym już treść Tez, jedynego oficjalnego dokumentu Departamentu, który zajął w tej materii wyraźne stanowisko. Znajdujemy w nim ważne zastrzeżenie, że ,izby pracy nie współzawodniczą z zorganizowanym ruchem zawodowym i nie ograniczają jego uprawnień", a także pozytywne stwierdzenie, że związki zawodowe stanowią ich podstawę organizacyjną ${ }^{153}$. Wskazanemu zastrzeżeniu towarzyszy jednak w tym samym zdaniu twierdzenie, że izby, współpracując z ruchem zawodowym, ,koordynują i uzupełniają jego działalność", a w tezie 1 uznano ponadto za jeden z podstawowych celów izb pracy ,scałkowanie” świata pracy.

Rozwinięcie tych ogólnych założeń znajdujemy w tezie 9, zawierającej szczegółowe wyliczenie zadań izb pracy, do których włączono „porządkowanie"154 i „ujednolicanie” działalności związków zawodowych. W kontekście pierwszego z tych sformułowań, któremu brak bliższego określenia, jest mowa o podejmowaniu

\footnotetext{
${ }^{151}$ Projekt 5, art. 5 ust. 3; projekt 4, art. 7 ust. 3; projekt 3, art. 7.

${ }^{152}$ Wymagało to rozporządzenia Ministra Pracy (Projekt 5, art. 5 ust. 4; projekt 4, art. 7 ust. 3.

Tezy IP, pkt 9m (wykonywanie administracji społecznej w zakresie zleconym).

${ }^{153}$ Tezy IP, pkt 3.

${ }^{154}$ W oryginalnym tekście ,podporządkowanie”, co stanowi oczywisty błąd maszynowy.
} 
inicjatyw zmierzających do utrzymywania dobrych stosunków międzyzwiązkowych poprzez sądownictwo polubowne oraz zapobieganie nielojalnej konkurencji. Ujednolicanie działalności związkowej miałoby natomiast dotyczyć spraw raczej formalnych, takich jak: statuty, składki, członkostwo związkowe, rachunkowość, sprawozdawczość. Do zadań izb pracy włączono również prowadzenie rejestru związków zawodowych, co należało przed wojną do inspekcji pracy.

Te ostatnie tezy znajdują rozwinięcie w treści projektów prawa o izbach pracy, w których jest mowa o czuwaniu nad dobrą współpracą między związkami zawodowymi oraz przyczynianiu się do doskonalenia ich wewnętrznej techniki administrowania ${ }^{155}$, ale także o uczestniczeniu w społecznej kontroli nad postępowaniem w życiu zawodowym, z czym miałoby się łączyć sprawowanie najwyższego sądownictwa dyscyplinarnego nad pracownikami ${ }^{156}$.

W treści projektów prawa znajdujemy również sformułowania nawiązujące do „całkującej” roli izb pracy, wyeksponowanej w Tezach. Na uwagę zasługuje tu postępowanie poprzedzające przedstawianie władzom dążeń i potrzeb ludzi pracy. Izby pracy miałyby opierać się przede wszystkim (a więc nie wyłącznie) na wskazówkach związków zawodowych, a następnie miałyby je „obiektywizować i ujednolicać", w czym przejawiłaby się z natury rzeczy pozycja nadrzędna izb pracy i upoważnienie do formułowania własnych ocen, opartych na spojrzeniu na sprawy pracownicze z szerszego punktu widzenia. Harmonizuje z tym przepis zawarty $\mathrm{w}$ innym projekcie, według którego wytyczną dla izb pracy miałoby być „ujednolicone stanowisko wszystkich związków zawodowych”"157, co zakłada oczywiście dokonywanie takiego ujednolicenia.

Za odrębne zadanie izb pracy zostało uznane zajmowanie stanowiska w sporach powstających na tle odwołań od uchwał rad zakładowych, o czym była mowa $\mathrm{w}$ części niniejszego rozdziału poświęconego radom. $\mathrm{W}$ treści jednego $\mathrm{z}$ projektów powiązano to $\mathrm{z}$ rolą izb, polegającą na zapoznawaniu się z życiem wewnętrznym zakładów pracy oraz na dopomaganiu kierownictwu zakładu i załodze w usuwaniu jego braków, a także na występowaniu do administracji pracy w przypadkach naruszenia prawa ${ }^{158}$.

W jednej kwestii nastąpiło wyraźne rozgraniczenie zadań związków zawodowych $\mathrm{i}$ izb pracy. Te ostatnie zostały mianowicie pozbawione prawa brania udziału w rokowaniach zbiorowych, mających za przedmiot warunki pracy i płacy, a także prawa uczestniczenia w układach zbiorowych pracy, w zatargach zbiorowych pracy i w postępowaniu pojednawczo-rozjemczym ${ }^{159}$. Pozostawało to $\mathrm{w}$ zgodzie z zasadniczym założeniem, według którego izby pracy powinny reprezentować

\footnotetext{
${ }^{155}$ Projekt 5, art. 7 ust. 1 i 2; projekt 4, art. 12 ust. 1.

${ }^{156}$ Projekt 5, art. 6 ust. 1 i 2; projekt 3, art. 5 ust. 2.

${ }^{157}$ Projekt 5, art. 1 ust. 3.

${ }^{158}$ Projekt 4, art. 9.

${ }^{159}$ Projekt 5, art. 12 ust. 1; projekt 4, art. 18 ust. 1.
} 
„syntezę pozytywnych, zgodnych dążeń zawodowych związków, pozostawiając im walkę z pracodawcami o warunki pracy i płacy"160.

Rozgraniczenie zadań pomiędzy związkami a izbami mogło jednak być potrzebne także w innych sprawach, zwłaszcza interesujących bezpośrednio zrzeszenia (centrale) związkowe. Zrzeszenia te mogły bowiem czuć się upoważnione - podobnie jak izby - do występowania z wnioskami i opiniami w sprawach dotyczących pracowników, a także do oddziaływania na ulepszanie form działalności związkowej, nie mówiąc już o rozwijaniu akcji samopomocowych. Pewien zakres tych spraw mógł również interesować poszczególne większe związki zawodowe, tym bardziej że zostały one upoważnione do reprezentowania zarówno pracowników zrzeszonych, jak i niezrzeszonych. Trzeba było zatem liczyć się z wątpliwościami co do właściwości jednych i drugich instytucji w sprawach leżących na pograniczu ich kompetencji.

Dokonanie precyzyjnych delimitacji tych materii przepisami rangi ustawowej byłoby praktycznie niemożliwe. W tym przekonaniu wprowadzono do projektów ustawowych przepis upoważniający Ministra Pracy do rozgraniczania zadań central związkowych i izb pracy, z braku wyraźnych wskazówek ustawowych, w trybie rozporządzeń ${ }^{161}$. Przepis ten miał wprawdzie wszelkie cechy regulacji do zastosowania w sytuacjach wyjątkowych (,w razie potrzeby”), niemniej jednak samo jego wprowadzenie świadczyło o zachodzeniu na siebie niektórych kompetencji wspomnianych wyżej instytucji, stanowiących podstawowe trzony ustroju pracy.

Rozstrzygające znaczenie dla ukształtowania wzajemnego stosunku związków zawodowych i izb pracy miało jednak określenie sposobu powoływania członków zasiadających w naczelnych organach, a więc w radach izb (wojewódzkich i centralnej). W założeniu było rzeczą jasną, że powinni to być delegaci pracowników, chodziło jednak o tryb ich wyłaniania. Projekt Departamentu Pracy i Opieki Społecznej odrzucił zdecydowanie koncepcję wyborów powszechnych (przez ogół pracowników) nie tylko aby uniknąć wygrywania antagonizmów, dzielących różne odłamy ruchu zawodowego, lecz również aby zapewnić wyłączną reprezentację $\mathrm{w}$ radach izb pracy pracownikom zrzeszonym ${ }^{162}$. W ten sposób znalazła pełne potwierdzenie teza uznająca związki zawodowe za podstawę organizacyjną izb pracy.

Członkowie rad w izbach pracy mieli być delegowani przez poszczególne zrzeszenia związków zawodowych w liczbie odpowiadającej liczebności ich członków (w danych okręgach i ew. branżach). Szczegółowe proporcje ustalane były różnie w kolejnych projektach ${ }^{163}$, zawsze jednak w taki sposób, aby delegaci ci stanowili zdecydowaną większość członków rady. Osobno mieli być

\footnotetext{
${ }^{160}$ Izby Pracy (sformułowania wstępne dyskusyjne), s. 7.

${ }^{161}$ Projekt 5, art. 12 ust. 3; projekt 4, art. 18 ust. 3.

${ }^{162}$ Izby Pracy (sformułowania wstępne dyskusyjne), s. 6.

${ }^{163}$ Projekt 5, art. 14 ust. 2 i 3; projekt 4, art. 24 ust. 2.
} 
delegowani przedstawiciele pracowników zatrudnionych w urzędach państwowych i samorządu terytorialnego ${ }^{164}$.

Uzupełniająco w skład rad w każdej izbie pracy mieli wchodzić, w ograniczonej liczbie, przedstawiciele kierowników zakładów pracy oraz osoby dokooptowane i mianowane, odznaczające się teoretyczną lub praktyczną znajomością zagadnień społeczno-gospodarczych i prawnych, związanych z działalnością izb pracy ${ }^{165}$. Organiczną część struktury izb pracy miały stanowić sekcje, zasadniczo w liczbie sześciu, odpowiadające następującym grupom gałęzi pracy: służba publiczna, przemysły kluczowe, pozostały przemysł i rzemiosło, rolnictwo wraz z ogrodnictwem i leśnictwem, handel i usługi osobiste oraz transport. W obradach sekcji mieli brać udział wyłącznie delegaci zainteresowanych zrzeszeń zawodowych i ew. funkcjonariuszy publicznych, a uchwały mogły zapadać tylko jednomyślnie ( $w$ braku osiągnięcia jednomyślności sprawa przechodziła na forum rady) ${ }^{166}$.

Osobną kwestię stanowiło stworzenie powiązań personalnych pomiędzy izbami pracy a izbami przemysłowo-handlowymi, rzemieślniczymi i rolnymi, stanowiącymi pozostałe ogniwa samorządu gospodarczego. Sama odrębność izb pracy odzwierciedlała przeciwstawność interesów czynnika pracy i kapitału, uzasadniającą przyznanie każdemu z tych czynników osobnej samorządnej reprezentacji ${ }^{167}$. Było to równoznaczne $\mathrm{z}$ odrzuceniem koncepcji korporacyjnej, która oznaczałaby tworzenie wspólnych organów reprezentacyjnych, np. w postaci włączenia przedstawicielstwa pracowniczego do izb przemysłowo-handlowych ${ }^{168}$.

Uznając jednak w pełni potrzebę powołania „,silnego, samodzielnego organu krystalizującego i obiektywizującego dążenia pracowników" w postaci wyodrębnienia samorządu (izb) pracy, dostrzegano równocześnie celowość stworzenia pewnych powiązań pomiędzy izbami reprezentującymi różne dziedziny i czynniki produkcji, co mogłoby sprzyjać lepszemu zrozumieniu wzajemnych interesów i rozwijaniu bardziej wyważonych form działania. Zgodnie z tą koncepcją należało dopuścić przedstawicieli pracowników do izb przemysłowo-handlowych i rolniczych oraz wzajemnie ,przedstawicieli samorządu grupy przedsiębiorców” do izb pracy ${ }^{169}$. Znalazło to wyraz w treści odpowiednich projektów ustawowych,

${ }^{164}$ Projekt 5, art. 15 ust. 1.

${ }^{165}$ Projekt 5, art. 14 ust. 1; art. 15 ust. 2 i 3; projekt 4, art. 24 ust. 1, 4 i 5.

${ }^{166}$ Projekt 5, art. 16; projekt 4, art. 23.

${ }^{167}$ Wymagało to natomiast stworzenia nadbudowy organizacyjnej, sprzyjającej ich harmonijnemu współdziałaniu w postaci organów stanowiących „ponadklasową formę zorganizowanego porządku społeczno-gospodarczego". Samorząd społeczno-gospodarczy i gospodarczy (maszynopis, s. 1, zbiory W.S.).

168 Samorząd społeczno-gospodarczy (praprojekt), s. 1 (gdzie jednak dopuszczono radę korporacyjną w sytuacjach, gdy „praca i kapitał łączą się w osobie gospodarującego”, a więc w rolnictwie i w rzemiośle).

${ }^{169}$ Ibidem, s. 1. 
które przewidziały delegowanie przez izby pracy swych przedstawicieli do izb gospodarczych (także do izby rzemieślniczej) w proporcji jednego radcy na dziesięciu zasiadających w tamtych izbach, na równych z nimi prawach ${ }^{170}$.

Ustrój wewnętrzny izb pracy miał być określony statutem uchwalanym przez radę izby, a zatwierdzanym przez Ministra Pracy. Ich organami stanowiącymi miały być rady o scharakteryzowanym wyżej składzie i sekcje. Organami wykonawczymi natomiast - prezes i zarząd. Prezesem zostawała każdorazowo osoba wybrana na przewodniczącego rady spośród jej członków lub spoza ich grona. Rada dokonywała też odpowiednio wyboru wiceprezesów w liczbie określonej statutem, przy czym osoby wybrane spoza jej składu stawały się z mocy tego wyboru jej członkami (dotyczyło to także prezesa). Prezes i wiceprezesi mieli stanowić łącznie zarząd izby, którego kompetencje nie zostały jednak bliżej określone.

Natomiast odrębnie wymieniono w projekcie dział wykonawczy, kierowany przez dyrektora mianowanego przez Ministra Pracy i mającego prawo uczestniczenia w zebraniach rady i sekcji z głosem doradczym. Mianowanie i odwoływanie dyrektora miało wprawdzie następować na wniosek rady, a sam dyrektor został podporządkowany prezesowi izby, niemniej jednak „dział wykonawczy” izby uzyskał inwestyturę pochodzącą bezpośrednio od naczelnego organu administracji pracy, co dawało mu mocną pozycję w stosunku do organów statutowych izby, tym bardziej że kompetencje zarządu nie zostały, jak już wspomniano, ściślej określone ${ }^{171}$.

Poza organami stanowiącymi i wykonawczymi miał działać również w izbach pracy organ sądowy w postaci sądu dyscyplinarnego i rzeczników dyscyplinarnych. Stanowiło to formę sprawowania przez izby pracy ,społecznej kontroli nad postępowaniem w życiu zawodowym osób czynnych gospodarczo", przy czym po stronie pracowniczej kontrola ta obejmowała zarówno pracowników zrzeszonych w związkach zawodowych, jak i niezrzeszonych. Członkowie sądów i rzecznicy dyscyplinarni mieli być wybierani przez rady izb, przy czym w Naczelnej Izbie Pracy miało działać sądownictwo dwuinstancyjne, natomiast w izbach wojewódzkich - jednoinstancyjne. Urzędnicy państwowi i samorządowi mieli podlegać sądownictwu dyscyplinarnemu izb pracy tylko za zgodą władz przełożonych. Ustrój sądów dyscyplinarnych, zasady postępowania przed nimi oraz rodzaje kar dyscyplinarnych miały być określone przez Ministra Pracy w drodze rozporządzenia ${ }^{172}$.

Sprawowanie nadzoru nad działalnością izb pracy zostało powierzone Ministrowi Pracy, któremu miało przysługiwać prawo składania z urzędu prezesa,

${ }^{170}$ Projekt 5, art. 29 ust. 1; projekt 4, art. 37 ust. 2. Odpowiednikiem tego rozwiązania było wspomniane wyżej uczestniczenie przedstawicieli kierowników zakładów pracy w izbach pracy.

${ }^{171}$ Projekt 5, art. 18-20; projekt 4, art. 26-28.

172 Projekt 5, art. 21; projekt 4, art. 29. Sądownictwo dyscyplinarne miało dotyczyć wyłącznie pracowników. Natomiast izby pracy mogły wyrażać uznanie za prowadzenie przedsiębiorstwa ,ze szczególnym zrozumieniem jego zadań społecznych" w postaci przyznawania znaku umieszczanego na jego wytworach (projekt 5, art. 6 ust. 3; projekt 4, art. 10). 
wiceprezesów i dyrektora izby, a także sędziów i rzecznika dyscyplinarnego oraz pozbawianie mandatu wszystkich lub niektórych członków rady. Minister został również upoważniony do rozwiązania izby pracy i wyznaczenia komisarza przejmującego uprawnienia wszystkich jej organów ${ }^{173}$.

Przepisami przejściowymi przewidziano powołanie Naczelnej Izby Pracy w ciągu 1 miesiąca, a izb wojewódzkich w czasie od 6 do 12 miesięcy, od dnia wejścia w życie projektowanego prawa. Krótkość tych terminów świadczyła niewątpliwie o znaczeniu przywiązywanym do szybkiego uruchomienia izb pracy, równocześnie stawiała jednak pod znakiem zapytania realność tych zamierzeń. Prawo o izbach pracy, podobnie jak inne akty podziemnego państwa o tym samym charakterze, miało bowiem wejść w życie w ciągu jednego miesiąca od dnia ogłoszenia przez właściwe władze o uwolnieniu danego obszaru spod okupacji ${ }^{174}$, a więc $\mathrm{w}$ czasie, w którym należało się liczył z natłokiem wielu pilnych zadań o niedającym się bliżej przewidzieć charakterze oraz z koniecznością wychodzenia naprzeciw najważniejszym potrzebom chwili. Trudno sobie wyobrazić, aby tworzenie izb pracy mogło w tych okolicznościach skupić na sobie szczególną uwagę, nawet gdyby miało być dokonane w uproszczonym, doraźnym trybie: w drodze powołania przez Ministra, a nie wyboru ${ }^{175}$.

W całości przedstawiony wyżej projekt wzbudzał mieszane odczucia. Przekonywająco została w nim przedstawiona sama potrzeba powołania izb pracy, jako instytucji o charakterze publicznoprawnym i oficjalnej reprezentacji całego świata pracy. Zasługiwała również na akceptację koncepcja oparcia struktury organizacyjnej izb pracy i ich organów na związkach zawodowych, jakkolwiek niektóre przepisy szczegółowe, regulujące stosunki wzajemne izb i związków, mogły budzić wątpliwości.

Najbardziej kontrowersyjna była jednak rozległość zadań, jakimi zamierzano obciążyć izby pracy w różnych dziedzinach życia społeczno-gospodarczego, krzyżujących się z rolą związków zawodowych i administracji pracy, a także rozbudowa struktury organizacyjnej izb na szczeblu centralnym oraz w przekroju terytorialnym i branżowym (sekcje), co nadawało im w sumie charakter instytucji wielofunkcyjnej i obarczonej nadmiarem zadań z trudem dających się ze sobą pogodzić.

Ocena przedstawionego wyżej projektu nie może być jednak dokonywana w oderwaniu od szerszych koncepcji ustrojowych, w stosunku do których stanowił on część składową. Izby pracy zostały bowiem od początku pomyślane jako element integralny samorządu społeczno-gospodarczego, stanowiącego swego

\footnotetext{
${ }^{173}$ Projekt 5, art. 24 i 25; projekt 4, art. 32 i 33. Miało to być przy tym, kuriozalnie, rozwiązanie na określony czas: od 3 miesięcy do 1 roku względnie do upływu kadencji izby.

${ }^{174}$ Projekt 5, art. 31.

${ }^{175}$ Projekt 5, art. 26. Przewidziano skrócony okres kadencji izb powoływanych w tym trybie (1 rok, a nie 2 lata, jak w zwykłym trybie).
} 
rodzaju nadbudowę nad izbami reprezentującymi różne dziedziny i czynniki produkcji. Tworzenie tego rodzaju struktur wykraczało już poza dziedzinę samego ustroju pracy, dopełniało go jednak, stwarzając podstawy do wzmocnienia roli czynnika społecznego i samorządnego w gospodarce i przeciwdziałając podporządkowaniu jej aparatowi biurokratycznemu administracji państwowej. Myśl ta stanowiła jedną z idei przewodnich programu przebudowy społecznej, przygotowywanego przez Departament Pracy, który podejmując ten wątek, wykraczał poza zakres swoich ścisłych kompetencji, korzystając z różnych inspiracji, ale znajdując raczej słaby oddźwięk w innych komórkach organizacyjnych Delegatury.

Okoliczność ta upośledzała z natury rzeczy omawiany kierunek prac, uniemożliwiając doprowadzenie ich do klarownych, należycie wyważonych konkluzji. Element postulatywny górował wyraźnie w tych pracach nad dojrzałą myślą programową. Inspirował on jednak znaczną część koncepcji wchodzących w zakres ustroju pracy i w tym sensie stanowił ich część składową. W związku z tym trudno byłoby zrezygnować z przedstawienia tego wątku, choćby tylko w ogólnym zarysie. Zadanie to podejmujemy w następnej, i ostatniej już, części niniejszego rozdziału.

\section{Idea samorządu społeczno-gospodarczego}

Koncepcja samorządu społeczno-gospodarczego wyrosła ze szczególnych przesłanek, o których była już mowa w niniejszej pracy, wydaje się jednak celowe przywołanie ich w uporządkowanej postaci, uwydatniając ich znaczenie. Pierwszą i główną z nich była planowość gospodarki, która stanowiła wprawdzie szeroko akceptowany postulat, nasuwała jednak równocześnie problemy, wobec których należało zająć stanowisko. Planowość ta zakładała bowiem aktywną rolę państwa, która z jednej strony wydawała się niezbędna w celu pchnięcia rozwoju gospodarczego kraju na nowe tory, ale z drugiej strony stwarzała zagrożenie etatyzacją i omnipotencją państwowego aparatu administracyjnego, pozbawiając życie społeczne jego autonomicznych treści.

Niebezpieczeństwo to dostrzegano od dawna w piśmiennictwie i w doktrynie, uświadamiano je sobie również w okupacyjnych pracach programowych. Poszukiwano w związku z tym takich rozwiązań ustrojowych, które oznaczałyby w ostatecznym wyniku raczej ,uspołecznienie” aniżeli ,upaństwowienie” gospodarki, ku czemu najwłaściwszą drogą wydawała się rozbudowa form samorządowych. Chodziło przy tym oczywiście nie o sam rozrost organów samorządu, lecz przede wszystkim o znaczne rozszerzenie ich roli i zakresu zadań, tak aby mogły one przejąć wiele funkcji spełnianych przez aparat państwowy i przyczynić się do zastąpienia w szerokim zakresie czynnika urzędniczego (biurokratycznego) przez czynnik społeczny. 
Roli tej nie mogły w ówczesnym przekonaniu wypełnić istniejące przed wojną formy samorządu gospodarczego i terytorialnego. Trzeba je było zatem dopełnić przez powołanie organów działających na szerszej płaszczyźnie i zdolnych do przejęcia znacznych obszarów wykonawstwa obciążającego dawniej aparat państwowy.

Druga przesłanka przemawiająca na rzecz rozbudowy samorządu wynikała z postulatu maksymalnej mobilizacji sił ludzkich w celu podźwignięcia na wyższy poziom gospodarki krajowej. Mobilizacja ta wymagała poświęcenia bieżących korzyści na rzecz przyszłych osiągnięć oraz podporządkowania grupowych interesów popieraniu dobra powszechnego. Było to możliwe tylko w szczególnym klimacie społecznym, wyzwalającym maksimum ofiarności i inicjatywy oraz dającym poczucie satysfakcji z aktywnego uczestniczenia we wspólnym dziele. Temu miało właśnie służyć stworzenie form ustrojowych zapewniających, mówiąc współczesnym językiem, upodmiotowienie ludzi pracy, a więc wyposażenie ich w realnie odczuwane prawo obywatelstwa społeczności gospodarczej. Rozwinięcie samorządnych form działania w atmosferze swobody i zaufania, w ramach prawnych stwarzających ku temu niezbędne gwarancje, zdawało się najlepiej służyć temu celowi.

Istotną rolę odgrywało również przeświadczenie, że życie przyszłej Polski wymaga nie tylko przebudowy społeczno-gospodarczej, lecz także odnowy moralnej, głębokiej przemiany postaw ludzkich i pobudek działania w kierunku umacniania poczucia wspólnoty i braterstwa oraz przezwyciężania partykularnych i grupowych linii podziału. Trzeba było zatem stworzyć formy współżycia i współdziałania sprzyjające takim przemianom i oddziaływające wychowawczo na rozwijanie konstruktywnych postaw i wspólnych dążeń do pomnażania sił i zasobów całego kraju. W tym zakresie również najlepszym rozwiązaniem wydawało się zapewnienie maksymalnych możliwości autonomicznego działania w formach opartych na zasadach swobody i samorządności, dającej szanse optymalnego kształtowania społecznego ładu.

$\mathrm{Z}$ takich przesłanek zrodziła się idea stworzenia wieloszczeblowych form samorządowych, wnikających głęboko w życie społeczne oraz organizujących współdziałanie jednostek ludzkich nie tylko poprzez normy prawne i struktury organizacyjne, lecz także poprzez normy obyczaju i etyki ${ }^{176}$. W dokumentach Departamentu można prześledzić stopniowe krystalizowanie się tych idei, poczynając od ogólnych ,praprojektów” i myśli programowych, aż do wyartykułowanych tez poprzestających jednak na zarysowaniu konturów projektowanych rozwiązań $^{177}$. Są to przy tym dokumenty przesycone głęboko treścią ideową i mające

176 Samorząd społeczno-gospodarczy (maszynopis, s. 4, zbiory W.S.).

177 Zachowały się następujące dokumenty: (1) Samorząd gospodarczy (z notatką odręczną M. Święcickiego: nasz praprojekt, maszynopis, stron 2, zbiory rodziny M. Święcickiego); (2) Samorząd społeczno-gospodarczy (maszynopis, stron 6, zbiory W.S.); (3) Samorząd 
raczej charakter wypowiedzi programowych, świadczących o silnym zaangażowaniu emocjonalnym autorów, aniżeli o gruntowniejszym przemyśleniu realnych rozwiązań.

Departament Pracy pozostawał tu wyraźnie pod wpływem koncepcji wypracowanych w okresie okupacji przez „Unię”178, czemu sprzyjał bezpośredni udział szefa Departamentu Stefana Matei w jej pracach. Postulaty „Unii” zmierzały do stworzenia ,powszechnego samorządu narodu” oraz opracowania ,planu uniwersalnej przebudowy moralno-politycznej”, z której miał się narodzić „nowy uspołeczniony człowiek"179. Idee te powstawały w klimacie ,grozy codzienności” wypełnianej przez walkę podziemną, co w szczególnym środowisku „Unii” sprzyjało, na zasadzie kontrastu, snuciu daleko sięgających planów na przyszłość, pełnych ,wysokich wzlotów i pragnień”, w których sam główny autor dostrzegał elementy ,zbiorowej ekstazy” i powątpiewał co do możliwości przeniesienia ich na grunt późniejszych realiów ${ }^{180}$.

Zachowane tezy „Unii” wypowiadały się za wyraźnym rozgraniczeniem kompetencji organów państwa i samorządu społeczno-gospodarczego o charakterze publicznoprawnym, ale także za stopniowym przejmowaniem funkcji administracji państwowej przez samorząd. Przewidywały swobodę tworzenia dobrowolnych zrzeszeń, uznawanych jednak za integralną część samorządu społeczno-gospodarczego i za jego organy ${ }^{181}$.

Główną rolę w świetle tych tez miały spełniać Wojewódzkie Rady Gospodarczo-Społeczne, kierujące całością życia gospodarczego na danym terenie. Rady te miały „dzielić się” na 4 izby: przemysłu, handlu, rzemiosła i wolnych zawodów, przy czym w każdej z nich mieli zasiadać przedstawiciele pracodawców i pracowników, tworzący odrębne sekcje: kapitału i pracy. Przyjęto zatem zasadę korporacyjną, która nie wykluczała wprawdzie odrębnych obrad każdej z tych sekcji w interesujących je sprawach, ale tylko wspólnemu ich działaniu nadawała charakter oficjalny: występowania w charakterze organu samorządu społeczno-gospodarczego. Wybory członków rad społeczno-gospodarczych i izb miały mieć charakter pośredni, poprzez zjazd wojewódzki (niekiedy powiatowy), w którym brali udział delegaci z poszczególnych zakładów pracy.

Ogólnokrajową władzą samorządu społeczno-gospodarczego miała być Naczelna Rada Społeczno-Gospodarcza, składająca się z przedstawicieli rad wojewódzkich oraz ogólnokrajowych stowarzyszeń i związków. Miało jej przysługiwać prawo inicjatywy ustawodawczej w szerokim zakresie spraw

społeczno-gospodarczy i gospodarczy (maszynopis w formie tez, stron 6, zbiory W.S.); (4) Ustrój pracy (maszynopis, stron 3, zbiory W.S.).

${ }^{178}$ Federacja Organizacji Narodowo-Katolickich „Unia” - przypis M.S.

179 J. Hoppe, Wspomnienia, przyczynki, refleksje, Londyn 1972, s. 279, 283, 285, 288.

${ }^{180}$ Ibidem, s. 290.

${ }^{181}$ Tekst bez tytułu zawierający uwagi krytyczne różnych środowisk (maszynopis, stron 13, zbiory rodziny M. Święcickiego), w tym tezy grupy „Unii” (s. 2-4, a zwłaszcza s. 9-13). 
objętych kompetencjami samorządu społeczno-gospodarczego. Nadzór nad pracami rady został natomiast powierzony Ministrowi Gospodarki Narodowej, harmonizującemu w dziedzinie społeczno-gospodarczej program prac rządu i samorządu. Struktura Naczelnej Rady odpowiadać miała strukturze rad wojewódzkich: przewidywano mianowicie działanie w jej ramach Centralnych Izb: Przemysłu, Handlu, Rzemiosła i Wolnych Zawodów, którym określone sprawy mogły być przekazywane do samodzielnej decyzji ${ }^{182}$.

Zapoznanie się z treścią tych tez pozwala stwierdzić, że wywarly one mniejszy wpływ na projekty opracowywane przez Departament, niż można to było dostrzec w płaszczyźnie ogólnych deklaracji ideowych. Departament nie akceptował przede wszystkim korporacyjnej struktury samorządu społeczno-gospodarczego, zachowując odrębne miejsce dla samorządu (izb) pracy. Odmiennie ukształtował też pełną listę izb wchodzących w skład rad społeczno-gospodarczych. Zaliczył do nich bowiem także izby rolnicze, samorządu terytorialnego i spółdzielczości, łącząc natomiast przemysł $i$ handel w jednej izbie przemysłowo-handlowej. Odrzucił również koncepcję wyborów pośrednich do rad, przyjmując, że członkami ich będą osoby delegowane przez izby odpowiedniego szczebla. Jedynie w Radzie Naczelnej przewidziano ponadto udział przedstawicieli nauki i osób delegowanych przez Prezesa Rady Ministrów, a także osób dokooptowanych przez Radę.

Departament zdecydował się równocześnie na szerszą rozbudowę organów samorządu, przewidując powołanie rad społeczno-gospodarczych już na szczeblu powiatów, a następnie województw i Izby Naczelnej. Już w powiatach miały też działać izby rolnicze i ewentualnie ekspozytury izb pracy, a wszystkie pozostałe izby w województwach i na szczeblu centralnym. Niejasno przedstawiała się natomiast w tezach Departamentu sprawa kierownictwa pracami rad. Z jednej strony przewidywano we wszystkich radach wybór zarządów (ich przewodniczących i członków) stanowiących organy wykonawcze. $Z$ drugiej strony jednak, zgodnie $\mathrm{z}$ treścią tez, w powiatowych radach miał przewodniczyć starosta, a w wojewódzkich - wojewoda. Nadzór nad działalnością rad miał natomiast należeć do rady szczebla bezpośrednio wyższego, z wyjątkiem Rady Naczelnej, która miała podlegać nadzorowi Prezesa Komitetu Ekonomicznego Ministrów ${ }^{183}$.

Kompetencje organów samorządu społeczno-gospodarczego obejmowały, w świetle tez Departamentu, niezmiernie szeroki zakres spraw, poczynając od współdziałania z Rządem, składania projektów i wniosków, poprzez prawo wydawania w określonych sprawach rozporządzeń, wykonywanie w pewnych zakresach funkcji administracji publicznej, sprawowanie nadzoru nad kartelami i przedsiębiorstwami uspołecznionymi, pełnienie działalności pojednawczo-rozjemczej w sporach zbiorowych pracy, kontrolowanie cen i inne. Był to w sumie

\footnotetext{
${ }^{182}$ Ibidem, s. 12-13.

${ }^{183}$ Samorzad spoleczno-gospodarczy i gospodarczy (przypis 177), s. 1-2.
} 
zakres działania niezmiernie szeroki, wykraczający poza zamierzenia „Unii”, której projekt przewidywał wprawdzie nakładanie na organy samorządu społecznogospodarczego wielu zadań w drodze ustawodawczej, ale główny nacisk kładł na pełnienie przezeń funkcji interwencyjnych oraz na kompleks spraw dotyczących czynnika pracy (rejestracja związków zawodowych i układów zbiorowych pracy oraz nadawanie im mocy powszechnie obowiązującej, ubezpieczenia społeczne, bezpieczeństwo i higiena pracy, pośrednictwo pracy, wczasy, warunki mieszkaniowe i aprowizacyjne), a ponadto na podnoszenie etyki zawodowej i akcję wychowawczą wśród członków ${ }^{184}$.

W tym stanie rzeczy projekt Departamentu nie miał szans na pozytywną ocenę ze strony głównych ośrodków społeczno-politycznych. Stronnictwo Ludowe („Trójkąt”) zarzuciło mu rozbudowywanie aparatu samorządowego do „monstrualnych rozmiarów” stanowiących „piramidę biurokratyczną" 185 . Podważało to zasadniczy sens projektu, było jednak o tyle uzasadnione, że tworzenie tak rozległych struktur, nawet mających w założeniu charakter samorządowy, mogłoby istotnie prowadzić do obrastania aparatem biurokratycznym.

PPS-WRN („Koło”) zakwestionowało samą zasadę podziału samorządu na „gospodarczy” (izby) i ,społeczno-gospodarczy” (rady), co musiałoby jej zdaniem prowadzić do ,podwojenia prac” w wielu dziedzinach oraz do „niebezpiecznej dwutorowości”, rodząc równocześnie spory kompetencyjne. Partia ta zarzuciła również projektowi zminimalizowanie pozycji Rządu przez sprowadzenie go do roli „rady nadzorczej spółdzielni”, wówczas gdy to właśnie on i administracja państwowa, a nie samorząd, są powołane do „podporządkowywania interesów klasowych dobru powszechnemu”186. Krytyczne uwagi zgłosiła również „Unia”, kwestionując sposób określenia zadań, obciążających rady społeczno-gospodarcze, a także rolę starostów i wojewodów jako ich przewodniczących ${ }^{187}$.

W tym stanie rzeczy idea samorządu społeczno-gospodarczego nie miała szans zakorzenienia się w pracach programowych Delegatury Rządu. Przedstawione powyżej uwagi krytyczne pochodzące z pierwszego półrocza 1943 r. ${ }^{188}$ położyły wyraźnie kres lansowaniu tych koncepcji. Punk ciężkości prac programowych przesunął się wyraźnie ku projektom utworzenia organów reprezentujących różne dziedziny i czynniki gospodarcze, a więc izb pracy, o których była mowa w po-

${ }^{184}$ Tekst bez tytułu (por. przypis 181), s. 10 .

${ }^{185}$ Ibidem, s. 1.

186 Ibidem, s. 2.

${ }^{187}$ Ibidem, s. 3. Krytyka dotyczyła także samej instytucji Komitetu Ekonomicznego Rady Ministrów, uznanej za przestarzałą.

${ }^{188}$ Uwagi „Koła” nosiły datę 30 III 1943. Należy sądzić, że uwagi innych ośrodków społecznopolitycznych zostały sformułowane w tym samym czasie lub niewiele później. Nie zachowały się żadne dokumenty świadczące o kontynuowaniu przez Departament prac nad problematyką samorządu społeczno-gospodarczego po tej dacie. 
przedniej części niniejszego rozdziału, izb przemysłowo-handlowych ${ }^{189} \mathrm{i}$ innych. Trzeba natomiast zauważyć, ze idea szeroko pojętego samorządu wykraczającego poza te ramy była żywa w wypowiedziach programowych różnych ośrodków myśli politycznej oraz niektórych organów polskiego państwa podziemnego ${ }^{190}$.

${ }^{189}$ Departament Przemysłu i Handlu opracował w szczególności następujące dokumenty - projekty: (1) Dekret o tymczasowym samorzadzie przemystu, rzemiosta i handlu (AAN, KC PZPR 202-VI/4, s. 163-168); (2) Dekret o tymczasowym samorzadzie przemystu, rzemiosta i handlu (inna wersja), AAN, 202/V/4, k. 29-38; (3) Dekret o tymczasowej organizacji samorzadu gospodarczego przemystu, rzemiosta $i$ handlu (AAN 202/V/4, k. 15 -17).

${ }^{190}$ Por. Organizacja państwa społecznego - dokument programowy grupy „Sprawy” (tekst bez tytułu, przypis 181, s. 4-9) oraz Postulaty organizacyjne przemystu wojennego (dokument Biura Wojskowego Przemysłu AK, AAN, 203/III-22, k. 142-143), gdzie mówi się wyraźnie o potrzebie stworzenia warunków do rozwijania inicjatywy społecznej, zorganizowanej na zasadach samorządu społeczno-gospodarczego i branżowego. 


\section{Prawo pracy}

Treść niniejszego rozdziału, a zwłaszcza jego pierwszej części, pozostaje $\mathrm{w}$ ścisłej łączności tematycznej z poprzednim rozdziałem. Jest to zbliżenie tak daleko idące, że nawet sam podział materii między te dwa rozdziały może budzić wątpliwości. Podstawy prawne rad zakładowych i związków zawodowych zaliczane są bowiem powszechnie do prawa pracy, a w szczególności do tej jego części, która określana jest jako prawo zbiorowe. Wydawało się jednak właściwe, w celu lepszego przedstawienia koncepcji Departamentu, scharakteryzowanie najpierw podstaw instytucjonalnych postulowanego ustroju pracy, a następnie osobno form prawnych regulujących zasady jego funkcjonowania. Ten ostatni wątek, dotyczący stosunków wzajemnych między organizacjami świata pracy i innymi podmiotami, podejmujemy w pierwszej części niniejszego rozdziału. W następnej jego części zajmiemy się natomiast prawem określającym sytuację poszczególnych pracowników wobec pracodawców i wobec państwa. Odpowiada to podziałowi prawa pracy na prawo zbiorowe i indywidualne.

\section{Zbiorowe prawo pracy}

\section{Uwagi wstępne}

Prace koncepcyjne Departamentu w tym zakresie zostały później podjęte i były mniej zaawansowane od przedstawionych w poprzednim rozdziale. W efekcie przygotowano projekty, które obejmowały wprawdzie całość zbiorowego prawa pracy w podanym wyżej rozumieniu, ale nosiły cechy wewnętrznych opracowań roboczych, dalekich jeszcze od nadania im ostatecznej formy, pozwalającej na wystąpienie z nimi na zewnątrz. Były to w szczególności dwa projekty dekretów regulujących osobno: układy zbiorowe pracy ${ }^{1}$ oraz „,pojednanie

${ }^{1}$ AAN, KC PZPR 203/VII/35, t. 2, k. 166-170. 
i rozjemstwo" w zatargach zbiorowych pracy², tudzież późniejszy w stosunku do nich projekt obejmujący łącznie obie te materie ${ }^{3}$, o którym należy sądzić, że powstał już w końcowej fazie prac Departamentu jako jeden z ostatnich jego dokumentów. Zachowało się również wcześniejsze opracowanie tezowe pt. Zbiorowe prawo pracy $i$ rozjemstwo ${ }^{4}$, które może być pomocne w odczytaniu koncepcji Departamentu wyrażonych w tamtych projektach.

Opracowania powyższe świadczą wyraźnie o tym, że intencją Departamentu było unormowanie zbiorowego prawa pracy w całości, i to jednym aktem normatywnym, a nie tylko poszczególnych jego instytucji, jak to miało miejsce w przedwojennym porządku prawnym. Zbiorowe prawo pracy miało w tej koncepcji stanowić „system jednolity”, łącznie z rozjemstwem odgrywającym wobec niego rolę pomocniczą ${ }^{5}$. Miało to być „prawo ludzi pracy” wypełniające „pustkę prawną" między indywidualnymi umowami o pracę a prawem stanowionym przez państwo ${ }^{6}$. Jako „pochodzące ze współdziałania [...] pracowników i pracodawców”, a więc „z bezpośredniego pobliża” normowanych przez nie stosunków, miało ono zapewniać „,dobieranie trafnych form [...] elastycznych i dostosowywanych do rzeczywistości”, a ze względu na „parytetyczne źródło” miało służyć „realizacji sprawiedliwości społecznej”.

Zarówno w tezach, jak i w projekcie dekretu określono wyczerpująco akty prawotwórcze, składające się na ten dział prawa. Zaliczono do nich mianowicie:

1) akty normatywne (uchwały) samorządu społeczno-gospodarczego;

2) układy zbiorowe pracy i orzeczenia rozjemcze;

3) regulaminy zakładowe

Na uwagę zasługuje fakt, że wyliczenie powyższe objęło zarówno akty stanowione jednostronnie przez upoważniony do tego organ (radę społeczno-gospodarczą, komisję rozjemczą, radę zakładową), jak i akty dochodzące do skutku w drodze dwustronnego porozumienia (układy zbiorowe pracy). Znaczenie tej okoliczności postaramy się uwydatnić w toku dalszych rozważań.

Kolejność powyższego wyliczenia odpowiada natomiast hierarchii ważności wymienionych aktów. Uchwały samorządu społeczno-gospodarczego uzyskały w niej miejsce naczelne, tak że układy nie mogły uchybiać ich treści, a co więcej

${ }^{2}$ Ibidem, k. 171-175.

${ }^{3}$ Prawo o zbiorowym prawie pracy (Red. B 1), AAN, KC PZPR 203/VII/35, t. 2, k. 141-152, cytowany dalej jako projekt ZPP.

${ }^{4}$ Zbiorowe prawo pracy i rozjemstwo, AAN, KC PZPR 203/VII/35, t. 2, k. 153-156a.

${ }^{5}$ Tezy ZPP, pkt 1.

${ }^{6}$ Ibidem, pkt 4.

${ }^{7}$ Ibidem, pkt 2 i 4; projekt ZPP, art. 1 ust. 1.

${ }^{8}$ Tezy ZPP, pkt 2; projekt ZPP, art. 1 ust. 3. Uchwały samorządu społeczno-gospodarczego uważane były za źródło zbiorowego prawa pracy w tym zakresie, w jakim dotyczyły treści indywidualnych stosunków pracy i zobowiązań wzajemnych organizacji reprezentujących pracowników i pracodawców. 
uchwały późniejsze miały być wyposażone w moc zmieniania zawartych poprzednio układów. Podobnie określony został stosunek wzajemny układów i regulaminów pracy ${ }^{9}$, które podlegały zresztą kontroli pod kątem zgodności z prawem ustawowym i układowym.

Bliższe uregulowanie trybu podejmowania uchwał przez organy samorządu społeczno-gospodarczego miało nastąpić w ustawie powołującej do życia ten samorzą ${ }^{10}$. Do przygotowania tej ustawy jednak, jak wiadomo, nie doszło, na skutek czego ta część zamierzonej regulacji zawisła w próżni. Natomiast w kwestii regulaminów pracy omawiane przez nas dokumenty odsyłały do gotowego już projektu dekretu o radach zakładowych, który doczekał się następnie promulgacji.

Właściwa materia objęta zakresem projektu Prawa o zbiorowym prawie pracy sprowadzała się zatem ostatecznie do dwóch kwestii, a mianowicie do uregulowania układów zbiorowych pracy oraz trybu postępowania w przypadku zatargów zbiorowych pracy, a w szczególności procedur pojednawstwa i rozjemstwa, z czym wiązało się ściśle prawo strajku. Treść projektu została w związku z tym podzielona (poza przepisami ogólnymi oraz karnymi i przejściowymi) na dwie części odpowiadające przedmowo tym materiom.

Nowe unormowanie każdej z nich było w istocie potrzebne, a dokonanie tego łącznie w jednym akcie mogło przedstawiać pewne zalety ze względu na ich pokrewieństwo. Problemy, wymagające rozwiązania w każdym $\mathrm{z}$ tych zakresów, były jednak zasadniczo odmienne. Układy zbiorowe pracy zostały unormowane na krótko przed wojną w ustawie z 1937 r., która pomimo widocznej w niej tendencji do wzmocnienia roli państwa, przynosiła niewątpliwie korzyści pracownikom i została przyjęta przychylnie w środowisku związkowym ${ }^{11}$. Stała ona również na wysokim poziomie legislacyjnym. W tym aspekcie zatem zadanie sprowadzało się do skorygowania regulacji prawnej w zakresie uznanym za niezbędne, a zwłaszcza rozciągnięcie jej na gałęzie pracy przez nie pominięte (rolnictwo). Nie zachodziła natomiast potrzeba normowania tej materii zupełnie na nowo.

W zakresie załatwiania zatargów zbiorowych pracy sprawa przedstawiała się natomiast odmiennie. Przedwojenny stan prawny był tutaj wysoce niezadowalający i nie stanowił konsekwentnej całości. Odrębne unormowanie (już w 1919 r.) rozjemstwa w rolnictwie, wymuszone szczególną sytuacją społeczną na wiejskim rynku pracy, było w istocie przejawem dyskryminowania tej gałęzi, która pozostawiona została poza systemem powszechnego prawa pracy, zastępowanego w stosunku do niej przez orzeczenia rozjemcze ${ }^{12}$.

\footnotetext{
${ }^{9}$ Projekt ZPP, art. 2 ust. 2 i 3.
}

${ }^{10}$ Tezy ZPP, pkt 15.

${ }^{11}$ M. Święcicki, Instytucje polskiego prawa pracy w latach 1918-1939, Warszawa 1960, s. 326, a także W. Szubert, Układy zbiorowe pracy, Warszawa 1960, s. 56 i n.

${ }^{12}$ W 1924 r. rozjemstwo to nabrało charakteru przymusowego. Por. M. Święcicki, op. cit., s. 43 i n. oraz 103 i n., a także A. Ajnenkiel, Położenie prawne robotników rolnych w Polsce (1918-1939), Warszawa 1962, s. 52 i n., 162 i n., 206 i n. 
Natomiast w przemyśle i w handlu powołano dopiero w 1933 r. nadzwyczajne komisje rozjemcze, których zakres działania został ograniczony do sytuacji wyjątkowych, gdy zatarg zbiorowy stwarzał „zagrożenie ogólnopaństwowych interesów gospodarczych". Nowelizacja z 1937 r. stworzyła podstawy do szerszego stosowania tego trybu, nadal jednak uciekano się do niego z pewną ostrożnością, aby uniknąć angażowania organów państwowych w rozstrzygnięcia, których wprowadzenie w życie trudno byłoby wymusić $\mathrm{w}$ istniejącym układzie sił społecznych. $\mathrm{Z}$ tych też względów nie uzyskały mocy prawnej projekty, zmierzające do stworzenia ,pełnego" systemu pojednawstwa i rozjemstwa, który miałby znacznie powiększyć ingerencję państwa $\mathrm{w}$ zbiorowe stosunki pracy ${ }^{13}$. Przedmiotem krytyki było obciążenie inspekcji pracy funkcjami pojednawczo-rozjemczymi, które uniemożliwiały jej koncentrowanie się na właściwym zakresie zadań, jaki stanowiło sprawowanie nadzoru nad przestrzeganiem prawa ochrony pracy.

Osobny, niezmiernie ważny problem stanowiło unormowanie prawa do straj$\mathrm{ku}$, dla którego oczywiste zagrożenie stanowiło rozbudowywanie systemu przymusowego rozjemstwa. Prawo to nie zostało w okresie międzywojennym bliżej określone, z tym że w latach trzydziestych ulegało ograniczeniu poprzez akty normatywne dotyczące różnych materii ${ }^{14}$. W tym stanie rzeczy każdy z dwóch działów wyodrębnionych w projektowanym ,prawie o zbiorowym prawie pracy” wymaga poddania odrębnej ocenie.

\section{Układy zbiorowe pracy}

W stosunku do regulacji układów zbiorowych pracy zamierzeniem Departamentu było utrzymanie w mocy przeważającej części przepisów ustawy z 1937 r. ${ }^{15}$ Zmiany dotyczyły tylko niektórych kwestii, mających jednak z punktu widzenia charakteru układów zasadnicze znaczenie.

Przede wszystkim Departament zamierzał inaczej określić samą naturę prawną układu, odstępując od przyjętego w okresie międzywojennym modelu umowy normatywnej, rozumianego jako akt prawny o podwójnym charakterze, dochodzący do skutku jako umowa, ale stwarzający nie tylko zobowiązania wzajemne między stronami, lecz również normy kształtujące treść indywidualnych stosunków pracy między pracownikami i pracodawcami, jako „związanymi układem” z tytułu zawarcia go przez organizacje powołane do reprezentowania ich interesów.

W praktyce szczególną wagę przywiązywano do normatywnych postanowień układu jako stwarzających prawo, od którego nie wolno było odstępować

\footnotetext{
${ }^{13}$ M. Święcicki, op. cit., s. 331-337.

${ }^{14}$ W szczególności przez kodeks karny z 1932 r., konstytucję kwietniową z 1935 r. oraz dekret o ochronie niektórych interesów państwa z 1938 r. Por. M. Święcicki, op. cit., s. 347-349.

${ }^{15}$ Tezy ZPP, pkt 14.
} 
w umowach indywidualnych o pracę, na niekorzyść pracowników. Respektowano jednak również charakter układu jako umowy rodzącej zobowiązania wzajemne między jej uczestnikami, co uzasadniało zastosowanie do niego przepisów prawa cywilnego w części dotyczącej umów. Przesądzało to ostatecznie o traktowaniu układu zbiorowego pracy jako aktu o charakterze mieszanym, leżącego na pograniczu prawa publicznego i prywatnego ${ }^{16}$.

Intencją Departamentu było zerwanie z tą konstrukcją i uznanie układu zbiorowego pracy po prostu za akt normatywny, dochodzący wprawdzie do skutku przez „prawotwórcze współdziałanie” dwóch zainteresowanych stron, ale pozbawiony całkowicie cech umowy w cywilnoprawnym znaczeniu ${ }^{17}$. Nie oznacza to, aby układ miał być pozbawiony postanowień tworzących zobowiązania między uczestnikami. Ich prawotwórcze współdziałanie mogło się bowiem wyrażać również w ustanawianiu takich wzajemnych obowiązków. Dotyczyło to przy tym nie tylko układów zbiorowych pracy, lecz również uchwał samorządu społeczno-gospodarczego, orzeczeń rozjemczych i regulaminów pracy ${ }^{18}$. A w samych układach zobowiązania takie ulegały w szerokim zakresie rozciągnięciu w razie upowszechnienia ich mocy obowiązującej na organizacje pracowników i pracodawców, które nie uczestniczyły pierwotnie w ich zawarciu ${ }^{19}$.

Mechanizm ustanawiania treści obligacyjnych i normatywnych układu zbiorowego pracy został $\mathrm{w}$ ten sposób całkowicie upodobniony, co czyniło zbędnym odwoływanie się w jakimkolwiek zakresie do przepisów prawa cywilnego. Zbliżało to również bardzo do siebie różne akty zbiorowego prawa pracy, ponieważ formuła ,prawotwórczego współdziałania” miała zastosowanie do wszystkich tych aktów bez względu na różnice dotyczące trybu ich stanowienia. Koncepcja Departamentu sprowadzała się zatem ostatecznie do wyeksponowania reglamentacyjnej funkcji układu i zerwania jego powiązań z prawem cywilnym.

Dalsza odrębność projektowanego prawa dotyczyła trybu rejestracji układów zbiorowych pracy. Przede wszystkim od funkcji tej postanowiono odciążyć inspekcję pracy i powierzyć ją właściwym terenowo organom administracji pracy. Ponadto pewne zmiany dotyczyć miały trybu postępowania związanego z rejestracją. W razie niezgodności układu z normami wyższego rzędu przewidziano bowiem, poza wezwaniem stron do wprowadzenia odpowiednich zmian do treści układu, możliwość dokonania tych zmian bezpośrednio przez właściwy urząd. Dopuszczono ją zwłaszcza w przypadkach, gdy wadliwość treści układu miała charakter rażący, a nie dotyczyła spraw, które były przedmiotem zatargu między

\footnotetext{
${ }^{16}$ W. Szubert, op. cit., s. 74 i n.

${ }^{17}$ Tezy ZPP, pkt 5.

${ }^{18}$ Projekt ZPP, art. 1 ust. 2.

${ }^{19} \mathrm{Nie}$ dotyczyło to jednak zobowiązań „wynikających ze szczególnych stosunków między uczestnikami ustanawiającymi układ". Upowszechnieniu ulegały natomiast wszystkie zobowiązania służące ,polepszeniu warunków pracy”. Ibidem, art. 20 ust. 3.
} 
uczestnikami ${ }^{20}$. Do dokonania takich zmian został również upoważniony Minister Pracy w razie, gdyby strony nie uczyniły tego w ciągu 30 dni, pomimo wezwania ich przez właściwy urząd, z tym że przewidziano wówczas alternatywną możliwość przekazania sprawy przez Ministra do komisji rozjemczej ${ }^{21}$.

W razie odmowy zarejestrowania układu przez właściwy urząd miała przysługiwać stronom, podobnie jak w ustawie przedwojennej, droga sądowa. Nowością w projekcie było natomiast przyznanie Sądowi Najwyższemu prawa uchylenia lub zmiany postanowień zarejestrowanego już układu, w razie uznania ich za niezgodne z normami wyższego rzędu, także wówczas gdy sprawa ta była już poprzednio przedmiotem orzeczenia właściwego sądu ${ }^{22}$.

Ostatnia z rzędu konstrukcyjnych zmian wprowadzanych w projekcie nowego prawa dotyczyła tzw. upowszechniania układu zbiorowego pracy, a więc rozciągnięcia jego mocy obowiązującej na wszystkie zakłady pracy w danej gałęzi pracy lub na danym obszarze. Procedura tej tzw. generalizacji układów miała istotne znaczenie z punktu widzenia porządkowania stanu prawnego, obowiązującego w odniesieniu do stosunków pracy. Na tej drodze układ stawał się bowiem prawem także dla tych pracodawców i pracowników, którzy nie byli nim pierwotnie objęci. Działo się to przy tym poza ich wolą, na mocy zarządzenia upoważnionego organu administracji państwowej i dotyczyło w danym stanie prawnym wyłącznie postanowień normatywnych układu, a w nowym projekcie miało objąć również jego postanowienia obligacyjne, ze wskazanym wyżej ograniczeniem.

Poważne korzyści związane z generalizacją układów sprawiły, że tryb ten rozpowszechnił się w wielu krajach. Przewidywała go również ustawa z 1937 r., z tym że wymagała dla uczynienia zeń użytku, uprzedniego wniosku jednego z uczestników pierwotnego układu albo zainteresowanego związku bądź zrzeszenia. Wymagała też, aby układ mający podlegać generalizacji posiadał gospodarczo przeważające znaczenie $\mathrm{w}$ danej gałęzi pracy lub na danym obszarze ${ }^{23}$.

Projekt nowego prawa odstępował od tego ostatniego warunku, który został oceniony jako ,nieuchwytny”24, a ponadto upoważniał Ministra Pracy do nadawania układom mocy powszechnie obowiązującej z urzędu, a więc także bez wniosku zainteresowanych stron.

Oceniając całość przedstawionych wyżej zmian w zakresie prawa układowego należy stwierdzić, że zmierzały one wyraźnie w kierunku „poważnego wzmocnienia funkcji reglamentacyjnej" układu, a więc położenia nacisku na jego rolę jako aktu normatywnego, dochodzącego wprawdzie do skutku w drodze

${ }^{20}$ Ibidem, art. 13 ust 2 pkt. 2. Ustawa z 1938 r. przewidywała w takim przypadku możność wpisania układu do rejestru bez postanowień wadliwych, chyba że przypuszczać należało, iż bez tych postanowień strony nie zawarłyby układu (art. 13 ust. 3).

${ }^{21}$ Projekt ZPP, art. 13 ust. 3.

${ }^{22}$ Ibidem, art. 13 ust. 7.

${ }^{23}$ Art. 21 ust. 1 ustawy z 14 V 1937 r. o układach zbiorowych pracy (Dz. U. nr 31 poz. 242).

${ }^{24}$ Tezy ZPP, pkt 11. 
współdziałania uczestników reprezentujących obie strony stosunków pracy, ale uzyskującego następnie byt samoistny. Temu celowi miało służyć odcięcie się od wszelkich powiązań z cywilnoprawnymi konstrukcjami umownymi, a także uznanie układów za jeden ze składników zbiorowego prawa pracy, podporządkowany uchwałom samorządu społeczno-gospodarczego.

Wyrazem tychże intencji było nadanie Ministrowi Pracy dyskrecjonalnych uprawnień, umożliwiających korygowanie treści układu i przekształcanie go w prawo stanowione o szerokim zakresie mocy obowiązującej. Warto przy tym dodać, że uprawnienia Ministra obejmowały również upowszechnienie łączne kilku uzupełniających się układów, połączone z ogłoszeniem ich jednolitego tekstu ${ }^{25}$, co oznaczało już wyraźnie akt prawotwórstwa, odchodzący od treści pierwotnych porozumień między uczestnikami poszczególnych układów.

W projektach tych wyrażała się tendencja do porządkowania stanu prawnego w dziedzinie stosunków pracy, a w szczególności do urzeczowienia tej regulacji, tj. oparcia jej na obiektywnych przesłankach, wyłączających nieuzasadnioną dyferencjację. Chodziło w nich również o eliminowanie nieuzasadnionych nierówności w kształtowaniu uprawnień pracowniczych oraz upowszechnianie jednolitych kryteriów i zasad. Trzeba jednak zauważyć, że droga do realizacji tych słusznych tendencji była najeżona problemami i miała swoją cenę, którą stanowiło osłabienie roli układów jako autonomicznego prawa, wyrastającego bezpośrednio z negocjacji i porozumień zbiorowych. Dlatego trudno byłoby poddać przedstawione koncepcje Departamentu jednoznacznemu osądowi. W okresie przejściowym, bezpośrednio po wojnie, wiele mogło przemawiać za ich akceptacją. W dalszej perspektywie czasu mogły natomiast co do tego powstawać wątpliwości. Do wątku tego wypadnie nam powrócić w drugiej części niniejszego rozdziału.

Oceniając projekt Departamentu, trzeba również mieć na uwadze, że unikał on rozwiązań skrajnych, nieliczących się z wolą stron zawierających układ. Wola ta nie została bowiem pozbawiona prawotwórczego znaczenia nawet w przypadku, gdy układ został upowszechniony i w tym charakterze zaczynał niejako żyć własnym życiem. Wygaśnięcie pierwotnego układu (m.in. w trybie wypowiedzenia przez jedną ze stron) pociągało bowiem za sobą również wygaśnięcie ,zarządzenia o jego upowszechnianiu", z tym tylko że właściwy minister był władny przesunąć jego termin, a tym samym przedłużyć moc obowiązującą upowszechnionego układu, nie więcej niż o 12 miesięcy ${ }^{26}$.

Projekt Departamentu przewidywał również obowiązującą w dawnym prawie regułę, pozwalającą na przedterminowe zwolnienie uczestnika spod mocy układu zawartego na czas oznaczony ze względu na zasady dobrej wiary lub z uwagi

\footnotetext{
${ }^{25}$ Projekt ZPP, art. 20 ust. 2. Por. także Tezy ZPP, pkt 11, gdzie uzasadniano potrzebę „kompilowania równoległych układów, gdy wskazane jest upowszechnienie ich równoczesne”.

${ }^{26}$ Projekt ZPP, art. 21 ust. 1 i 2.
} 
na znaczną zmianę ogólnych warunków gospodarczych ${ }^{27}$. Projekt utrzymywał też w mocy zasadę, zgodnie z którą pracodawca występujący ze zrzeszenia, będącego uczestnikiem układu, pozostawał nadal związany tym układem tak długo, jak długo układ obowiązywał w stosunku do danego zrzeszenia ${ }^{28}$. Utrzymana została także w projekcie zasada, zgodnie z którą w przypadku zbiegu układów (tzw. gdy dany pracodawca był związany kilkoma układami), należało uznać za obowiązujące postanowienia najkorzystniejsze dla pracowników ${ }^{29}$.

Różnica $\mathrm{w}$ porównaniu $\mathrm{z}$ dawnym prawem polegała natomiast na tym, że dawna ustawa nakazywała stosować w całości układ najkorzystniejszy dla pracowników $^{30}$. Zakładało to potrzebę dokonania łącznej, porównawczej oceny wszystkich postanowień zawartych w obowiązujących układach i prowadziło do wskazania jednego układu jako w ogólnym wyrazie najkorzystniejszego. Projekt Departamentu zdawał się natomiast wypowiadać za mocą obowiązującą poszczególnych postanowień wybranych jako najkorzystniejsze dla pracowników z treści układów pozostających w kolizji ${ }^{31}$.

Zasadniczą wartość projektu przygotowanego przez Departament stanowiło objęcie prawem o układach zbiorowych pracy robotników rolnych, co - łącznie z innymi zamierzeniami legislacyjnymi, o których będzie dalej mowa - miało położyć kres upośledzeniu tej kategorii robotników w prawie pracy. Utrzymano natomiast wyłączenie spod mocy obowiązującej wszystkich przepisów o zbiorowym prawie pracy urzędników państwowych i samorządowych oraz uczniów w warsztatach szkolnych, pozostawiając do późniejszych ustaleń sprawę zastosowania tego prawa do członków załóg statków morskich, robotników portowych oraz pracowników monopoli państwowych ${ }^{32}$.

\section{Pojednawstwo i rozjemstwo}

Druga część Prawa o zbiorowym prawie pracy, poświęcona pojednawstwu i rozjemstwu, stanowiła próbę całościowego unormowania tych procedur. W koncepcji Departamentu miały one stanowić formę wkroczenia państwa do procesu tworzenia się prawa autonomicznego ${ }^{33}$. Ściślej biorąc, była to druga forma tej interwencji obok procedur związanych z rejestracją i upowszechnianiem układów

${ }^{27}$ Ibidem, art. 18 ust. 1.

${ }^{28}$ Ibidem, art. 8 ust. 1.

${ }^{29}$ Ibidem, art. 7 ust. 2.

${ }^{30}$ Ustawa z 14 V 1937, art. 10.

${ }^{31}$ Zasada ta stwarzała sytuację mniej przejrzystą, gdyż uznawała moc obowiązującą nie jakiegoś jednego układu w całości, lecz „kombinowanych postanowień różnych układów”. Por. W. Szubert, op. cit., s. 205.

${ }^{32}$ Tezy ZPP, pkt 13; projekt ZPP, art. 5.

${ }^{33}$ Tezy ZPP, pkt 17. 
zbiorowych pracy, o których była już mowa. Ograniczały one w sumie dość znacznie autonomiczność zbiorowego prawa pracy i kształtowały w poważnej mierze jego oblicze.

Doświadczenia okresu międzywojennego, przedstawione powyżej, uwydatniły newralgiczny charakter instytucji pojednawstwa i rozjemstwa w zbiorowych stosunkach pracy, a także jej ambiwalentną rolę zależną w decydującym stopniu od nasycenia jej elementami nacisku i przymusu. $Z$ jednej strony bowiem pojednawstwo i rozjemstwo sprzyjało zawieraniu ugód i znajdowaniu rozwiązań, które mogły być akceptowane przez strony pozostające w konflikcie, bez uciekania się do bezpośredniej próby sił. $Z$ drugiej strony natomiast przekroczenie pewnej granicy nacisku prawnego, równoznaczne z narzucaniem stronom obowiązkowych procedur i rozstrzygnięć rozjemczych, musiało prowadzić do nadmiernego ograniczenia swobody ich działania i mogło postawić pod znakiem zapytania poszanowanie wolności związkowej ${ }^{34}$. Trzeba było też mieć na uwadze, że rygory takie mogą okazywać się w pewnych sytuacjach nieskuteczne, ponieważ w dziedzinie zbiorowych stosunków pracy realne układy sił mają niekiedy większe znaczenie niż normy prawne.

Wszystkie te okoliczności wymagały rozważenia w fazie projektowania w tym zakresie nowych przepisów na przyszłość. Nie można było także pominąć szczególnych warunków i potrzeb okresu bezpośrednio powojennego (,„przejściowego"), o którym było wiadomo, że będzie wymagał mobilizacji i zharmonizowanego działania wszystkich sił społecznych oraz ponoszenia pewnych ofiar na rzecz stworzenia podstaw przyszłego rozwoju kraju. Niełatwo było w tych warunkach znaleźć optymalne rozwiązania w tej tak ważnej i z natury rzeczy konfliktowej sprawie. Potrzeba unikania zatargów i ostrych starć nasuwała się sama przez się, chodziło jednak o dobranie środków optymalnie służących temu celowi oraz o rozstrzygnięcie, w jakiej mierze mogą do tego przyczynić się normy prawne.

Treść tez w sprawie zbiorowego prawa pracy i rozjemstwa świadczy o podchodzeniu do tej sprawy z dużą rozwagą. Przed podjęciem tego tematu należy jednak wskazać, że intencją Departamentu było zapewnienie maksymalnej skuteczności rokowaniom zbiorowym, stanowiącym wstępną, nieformalną fazę postępowania $\mathrm{w}$ sytuacjach, gdy zarysowywała się między stronami rozbieżność stanowisk co do interpretacji obowiązującego prawa (układu) lub też gdy jedna ze stron występowała z inicjatywą jego zmiany.

Bezpośrednia ingerencja prawna $\mathrm{w}$ meritum takich rokowań nie wchodziła oczywiście w rachubę, zamierzeniem Departamentu było jednak wywarcie pewnego nacisku na samo ich podjęcie. Wyrazem tego było nałożenie na każdą ze stron zbiorowych stosunków pracy obowiązku przystąpienia do rokowań na wniosek strony przeciwnej. Taki właśnie przepis znalazł się, jak już wspomniano, w projektach prawa o związkach zawodowych. Obowiązek ten (,stanięcia do rokowań") miał ciążyć zarówno na związku zawodowym pracowników,

\footnotetext{
${ }^{34}$ Por. M. Święcicki, op. cit., s. 335.
} 
jak i odpowiednio na organizacji pracodawców (bądź samych pracodawcach), co oznaczało powinność uczestniczenia w pokojowym, wspólnym rozważeniu spraw, będących lub mogących stać się przedmiotem zatargu, w razie gdy druga strona podejmie taką inicjatywę. Prawo wywierało w ten sposób pewien nacisk na rozwiązywanie spraw konfliktowych przede wszystkim na drodze porozumienia zainteresowanych stron, zabraniając odrzucania takiej oferty i odpowiadania na nią od razu podjęciem akcji, stanowiącej formę walki i próby sił.

Regulacja taka, obca europejskiemu prawu pracy, przypominała natomiast ugruntowaną w Stanach Zjednoczonych instytucję duty to bargain, która zgodnie $\mathrm{z}$ ogólną orientacją zbiorowych stosunków pracy w tamtym kraju miała zastosowanie do rokowań prowadzonych w poszczególnych zakładach pracy ${ }^{35}$. Projekt Departamentu odnosił ją do inicjatywy podjęcia rokowań na dowolnym szczeblu i obwarowywał sankcjami przewidzianymi w jego przepisach karnych za naruszenie prawa $^{36}$.

Wracając do tez w sprawie zbiorowego prawa pracy i rozjemstwa, należy stwierdzić, że państwo miało zgodnie z ich treścią wkraczać poprzez procedury pojednawcze i rozjemcze tylko wówczas, gdy współdziałanie samych czynników powołanych do „tworzenia prawa autonomicznego" nie da wyniku. Formy tej ingerencji powinny być przy tym ,jak najbardziej różnorakie i elastyczne” oraz „uszeregowane według stopnia przymusowości i nacisku wywieranego zarówno przez władze, jak i przez opinię publiczną". Działalnością pojednawczą i rozjemczą miał kierować Minister Pracy, ale tylko do chwili powołania samorządu społeczno-gospodarczego, który miał przejąć w tym zakresie wykonawstwo „w całości lub w części” ${ }^{37}$.

Postępowanie pojednawcze miało mieć charakter dwuinstancyjny. Pierwszą instancję mieli stanowić rozjemcy społeczni ${ }^{38}$, powoływani przez Ministra Pracy „spośród osób znających zagadnienia pracy i mających zaufanie u pracowników i pracodawców" ‘9 , działający w poszczególnych powiatach i województwach, a niekiedy na całym obszarze kraju lub w określonych gałęziach pracy. Rozjemca społeczny miał „wykonywać jedynie stadium pojednawcze”, mógł on jednak nie tylko przeprowadzać badanie stanu faktycznego i proponować sposoby ugodowego załatwienia zatargu, lecz również ,wydawać orzeczenia na mocy zapisu polubownego uczestników” $\mathrm{i}$ to, jak dodano w projekcie dekretu, ,z mocą układu zbio-

${ }^{35}$ Por. X. Blanc-Jouvan, Les rapports collectifs aux Etats Unis, Grenoble 1956. Nie wydaje się jednak, aby było to świadome przejęcie tej instytucji przez Departament.

${ }^{36}$ Projekt 5 (dotyczący związków zawodowych), art. 44. Kary te mogły być nakładane tylko przez sąd.

${ }^{37}$ Tezy ZPP, pkt 17-20.

${ }^{38}$ Nazwani w tekście projektu ZPP niefortunnie ,jednaczami” (art. 25 i n.). W pracy niniejszej stosujemy konsekwentnie termin „rozjemcy społeczni”, przyjęty w Tezach ZPP, pkt 21 i n.

${ }^{39}$ Nie mogli być nimi urzędnicy państwowi (ibidem, pkt 21; projekt ZPP, art. 26 ust. 2). 
rowego pracy"40. Rozpatrzenie sprawy przez rozjemcę społecznego warunkowało przejście jej do „wyższych instancji pojednawczo-rozjemczych”41. Szczególnego znaczenia nabierał w związku z tym tryb wszczęcia postępowania przed rozjemcą oraz obowiązki ciążące w tym zakresie na stronach.

Tezy nie zajmują stanowiska w tej sprawie. Projekt reguluje ją natomiast w sposób mogący rodzić wątpliwości. Z jednej strony stanowi bowiem, że „każdy zatarg będzie przedstawiony" jednemu z właściwych rozjemców, co sugerowało narzucenie stronom obowiązku korzystania z postępowania pojednawczego. Z dalszych przepisów wynika jednak, że ,zgłoszenie zatargu” ma następować $\mathrm{z}$ inicjatywy stron ${ }^{42}$. Natomiast samym rozjemcom przyznano prawo wszczęcia postępowania pojednawczego ,z urzędu”, i to nawet przed powstaniem zatargu, jeżeli ujawniły się „,rozbieżności zdań co do wykonywania obowiązującego [ukła$\mathrm{du}]$ lub ustalenia treści przyszłego układu"43. Ostatecznie zatem zatarg mógł stać się przedmiotem postępowania pojednawczego poza wolą stron, a wpływ ich na bieg sprawy ograniczał się wtedy do wyboru właściwego forum ${ }^{44}$.

Drugą instancję miały stanowić wydziały pojednania we właściwych urzędach administracji pracy na szczeblu powiatu, województwa i centralnym. Przejście sprawy do tej instancji miało następować w przypadku, gdy sam rozjemca uzna bezcelowość podjęcia bądź kontynuowania podjętego przez siebie postępowania, bądź też gdy jeden z uczestników zażąda jego zakończenia. Natomiast wydział pojednania nie miał możności uchylenia się od rozpatrzenia sprawy, przy czym powinien, stosownie do potrzeby, dokonać tych samych czynności co rozjemcy działający w pierwszej instancji. Mógł ponadto nakazać uczestnikom zatargu, aby zapoznali się z projektem ugodowego załatwienia sprawy oraz aby wypowiedzieli się w tej sprawie na zwołanej przezeń konferencji. Mógł też zastosować szczególny sposób nacisku, polegający na podaniu do wiadomości publicznej przebiegu zatargu oraz treści wysuwanych żądań i dowodów przedstawionych na ich poparcie ${ }^{45}$.

Zakończenie postępowania pojednawczego następowało $\mathrm{z}$ dniem zawarcia przez strony układu regulującego sprawy sporne oraz $\mathrm{w}$ razie odrzucenia projektu załatwienia zatargu, jaki został przygotowany przez wydział. Wymagano jednak, aby odrzucenie to nastąpiło przez wszystkich uczestników zatargu występujących po jednej stronie, a ponadto, aby miało charakter ostateczny, tzn. nie było połączone $\mathrm{z}$ wnioskiem o przygotowanie nowego projektu. Na przedłużenie postępowania

${ }^{40}$ Tezy ZPP, pkt 23; projekt ZPP, art. 28 ust. 2.

${ }^{41}$ Tezy ZPP, pkt 22.

${ }^{42}$ Projekt ZPP, art. 27, przy czym strona, która uczyniła to pierwsza, korzystała z przywileju dokonania wyboru spośród właściwych rozjemców społecznych.

${ }^{43}$ Projekt ZPP, art. 28 ust. 3.

${ }^{44} \mathrm{Tj}$. wyboru jednego z rozjemców społecznych właściwych terenowo lub rzeczowo w sytuacji wskazanej wyżej (przypis 42, rozdział I).

${ }^{45}$ Projekt ZPP, art. 30 ust. 4. Tryb ten mógł być zastosowany tylko jeden raz w toku danego postępowania. 
pojednawczego mogło wpłynąć zapowiedzenie przez wydział, że w razie odrzucenia projektu ugody okoliczności zatargu zostaną podane do wiadomości publicznej ${ }^{46}$ (a więc zastosowanie szczególnego trybu wspomnianego powyżej). Jak widać, projekt dekretu zmierzał różnymi drogami do przeciągnięcia postępowania pojednawczego i doprowadzenia go do pozytywnego wyniku.

W przypadku jednak, gdy nie udałoby się tego osiągnąć, przewidziana została druga faza postępowania, mającego już charakter nie pojednawczy, lecz rozjemczy. Organem powołanym do działania w tej roli miały być komisje rozjemcze, składające się z członków powoływanych przez Ministra Pracy (przewodniczący kompletów i kierownicy komisji) oraz przez innych ministrów, odpowiednio do gałęzi pracy, których zatarg dotyczył, i przez Ministra Sprawiedliwości. W skład komisji rozjemczych wchodzili również ławnicy, powoływani przez kierowników komisji spośród kandydatów, przedstawionych przez izby pracy oraz izby przemysłowo-handlowe, rzemieślnicze i rolnicze. Dla każdego zatargu kierownik komisji miał wyznaczać komplet, składający się z przewodniczącego, dwóch członków stałych i od 2 do 6 ławników (po połowie z każdej ze stron), zależnie od doniosłości i zawiłości zatargu. Podobnie jak rozjemcy społeczni, komisje rozjemcze miały działać na szczeblu powiatu, województwa i ogólnokrajowym ${ }^{47}$.

Sprawą o kluczowym znaczeniu był tryb wszczynania postępowania rozjemczego oraz stopień uzależnienia go od woli uczestników zatargu. Pod tym względem projekt zajmował dość rygorystyczne stanowisko. Określał przede wszystkim gałęzie pracy, w których przekazanie zatargu do komisji rozjemczych następowało „Z urzędu”. Należały do nich zakłady użyteczności publicznej, rolnictwo i ogrodnictwo oraz zakłady pracy podporządkowane Ministerstwu Spraw Wojskowych. W pozostałych gałęziach pracy uczestnicy zatargu nie mogli jednak również swobodnie decydować o wejściu na drogę rozjemstwa. Prawo podejmowania decyzji wiążących w tej materii zostało bowiem przekazane Ministrowi Pracy ${ }^{48}$.

Zamierzano zatem, zgodnie z treścią projektu, wprowadzić tryb, który nadawał $\mathrm{w}$ istocie postępowaniu rozjemczemu charakter przymusowy, a w każdym razie ograniczał bardzo zakres spraw, w których uczestnicy zatargu mogli mieć wpływ na jego wszczęcie. Należało bowiem oczekiwać, że we wszystkich sprawach, mających większe znaczenie gospodarcze, Minister Pracy będzie korzystał z przyznanego mu uprawnienia. Przyjęcie takiego rozwiązania sprawy pociągnęło za sobą daleko idące konsekwencje.

Trzeba przede wszystkim stwierdzić, że projekt dekretu przewidywał tylko jeden sposób zakończenia postępowania rozjemczego, a mianowicie przez wydanie orzeczenia uznanego za równoważne zawarciu układu zbiorowego pracy, jakkolwiek wyrażało ono wolę organu rozjemczego, a nie stron biorących udział

\footnotetext{
${ }^{46}$ Ibidem, art. 32.

${ }^{47}$ Ibidem, art. 33-36.

${ }^{48}$ Ibidem, art. 33 ust. 3 i 4.
} 
w zatargu. Projekt dekretu starał się zatrzeć, czy co najmniej osłabić, tę różnicę, stwierdzając że strony stają się, podobnie jak w przypadku układu, „uczestnikami orzeczenia" ${ }^{49}$, mając zapewne na uwadze fakt, że orzeczenia rozjemcze miały być wydawane przez organ o charakterze mieszanym, w którym zasiadali jako ławnicy przedstawiciele obu stron będących w sporze.

Należało też zakładać, jakkolwiek projekt dekretu wyraźnie tego nie mówił, że decyzje o treści orzeczenia będą mogły być podejmowane tylko jednomyślnie, tzn. że przedstawiciele żadnej ze stron nie będą mogli być przegłosowani (przez mianowanych członków komisji i ławników drugiej strony). Uczestnicy zatargu nie mieli jednak wpływu na dobór ławników zasiadających w danym komplecie, ponieważ decydował o tym kierownik komisji rozjemczej, ani na treść samego orzeczenia, ponieważ stanowisko ich mogło nie być zgodne z przyjętym przez ławników reprezentujących daną stronę.

Wszystko to nadawało orzeczeniu rozjemczemu charakter aktu stanowionego jednostronnie, jakkolwiek przy udziale przedstawicieli obu stron. Projekt dekretu zaliczał je jednak do źródeł zbiorowego prawa pracy, uznając - jak wiadomo - za differentia specifica wszelkich aktów zaliczanych do tego prawa fakt powstawania „,z prawotwórczego współdziałania grupy pracowników i grupy pracodawców lub części tych grup" oraz wyposażając te akty w moc ustanawiania wzajemnych obowiązków między tymi grupami” i ,przepisów dla jednostkowych stosunków pracy" (a także stosunków służbowych i stosunków nauki zawodu).

Pokrewieństwo między układem zbiorowym pracy i orzeczeniem rozjemczym wyrażało się m.in. w tym, że jednakowo określony został krąg ich uczestników (po stronie pracowników tylko związki zawodowe, po stronie przeciwnej także pojedynczy pracodawcy $)^{50}$. Przewidziano ponadto możność „poddania się orzeczeniu" przez związki i pracodawców, którzy nie uczestniczyli w zatargu (co stanowiło odpowiednik przystąpienia do układu przez outsiderów) ${ }^{51}$. Odrębność orzeczenia rozjemczego od układu miała polegać natomiast na tym, że przewidziano wydawanie go wyłącznie na czas oznaczony ${ }^{52}$.

\section{Prawo do strajku}

Najważniejszy był jednak wpływ, przymusowego w istocie, postępowania rozjemczego na prawo podejmowania jednostronnych akcji o charakterze zbiorowego przerwania świadczenia pracy (strajk) czy też odebrania możności tego świadczenia (lokaut). Projekt dekretu wkraczał głęboko w te sprawy, określając

\footnotetext{
${ }^{49} \mathrm{Ibidem}$, art. 37 ust. 2.

${ }^{50} \mathrm{Ibidem}$, art. 6 ust. 1 oraz art. 25 ust. 2. Orzeczenia rozjemcze podlegały też, na równi $\mathrm{z}$ układami zbiorowymi pracy, rejestracji.

${ }^{51}$ Ibidem, art. 37 ust. 2.

${ }^{52}$ Ibidem, art. 37 ust. 3.
} 
warunki, od których miała zależeć legalność tego rodzaju akcji. Do warunków tych zaliczono przy tym, po stronie pracowniczej, nie tylko wymóg, aby inicjatywa, organizacja i kierownictwo strajku należały do związku zawodowego i aby jego podjęcie zostało wcześniej zgłoszone organowi administracji pracy i podane do wiadomości strony przeciwnej, lecz również aby dany zatarg nie podlegał obowiązkowemu przekazaniu na drogę rozjemstwa ${ }^{53}$.

Legalność strajku została tym samym wyłączona $\mathrm{w}$ gałęziach pracy podlegających ex lege temu postępowaniu, a w pozostałych gałęziach w razie skorzystania przez Ministra Pracy z prawa skierowania sprawy na tę drogę. Od decyzji Ministra miało tym samym ostatecznie zależeć, czy związki zawodowe będą mogły skorzystać z prawa do strajku po zakończeniu postępowania pojednawczego. $\mathrm{Z}$ chwilą bowiem gdy na mocy jego decyzji (lub ex lege) zostałoby wszczęte postępowanie rozjemcze, uczestnicy zatargu byli zobowiązani brać w nim udział, a po wydaniu orzeczenia rozjemczego byli związani jego treścią, tak że nie pozostawała im już żadna możliwość podjęcia legalnej akcji strajkowej. Akcje nielegalne zostały natomiast zagrożone sankcjami karnymi ${ }^{54}$.

Rygoryzm tych postanowień zawartych w projekcie dekretu o zbiorowym prawie pracy wymaga pewnego komentarza. Przede wszystkim trzeba zauważyć, że żadne ograniczenia tego rodzaju nie były przewidywane w projektach dotyczących podstawowych instytucji ustroju pracy, a w szczególności związków zawodowych. Projekt dekretu o związkach wspominał wprawdzie o możliwości ograniczeń wynikających z innych przepisów, sam jednak ograniczał się do wymogu, aby podmiotem występującym w charakterze inicjatora i organizatora strajku był związek zawodowy ${ }^{55}$. Nie zawierały również żadnych postanowień ograniczających prawo do strajku tezy Departamentu dotyczące związków zawodowych, stwierdzające jedynie, że do zadań ich należy m.in. uczestniczenie „w procedurach układowych, pojednawczych, rozjemczych i strajkowych"s6.

Zamierzenie ograniczenia prawa do strajku nie znalazło zatem wyrazu w żadnym oficjalnym dokumencie Departamentu ani w projektach będących owocem jego dojrzałej rozwagi, jakkolwiek niemających jeszcze charakteru ostatecznego. Natomiast projekt dekretu o zbiorowym prawie pracy, zawierający postanowienia restrykcyjne w tej materii, powstał w końcowej fazie prac Departamentu w warunkach, gdy trudno go było poddać pełnemu rozważeniu w gronie jego współpracowników. Okoliczności wskazują też wyraźnie na fakt, że nie uzyskał akceptacji szefa Departamentu Stefana Matei. Nosił on poza tym cechy dokumentu niedopracowanego pod względem językowym i redakcyjnym, dalekiego od nadania mu przekonywającej, skrystalizowanej formy.

\footnotetext{
${ }^{53}$ Ibidem, art. 39, ust. 1 i 2.

${ }^{54} \mathrm{Ibidem}$, art. 43 ust. 3 i 4 . Kary te obejmowały areszt do 2 lat i grzywnę oraz złożenie z urzędu władz związku.

${ }^{55}$ Projekt 5 (dotyczący związków zawodowych), art. 9 ust. 9.

${ }^{56}$ Tezy dotyczące związków zawodowych, pkt 6 b.
} 
Projekt ten nie wyrażał stanowiska Departamentu, świadczył natomiast o tym, że rozwiązania w nim zawarte były brane pod uwagę w wewnętrznych dyskusjach, pomimo krytycznej oceny przedwojennych tendencji antystrajkowych. Wyrastały one niewątpliwie z przekonania, że w okresie powojennym będzie konieczne przezwyciężenie sprzeczności interesów grupowych w dążeniu do zapewnienia planowego rozwoju gospodarki. Projekt, o którym mowa, wykraczał jednak poza ogólnie przyjęte rozumienie okresu przejściowego, w stosunku do którego zawierał odrębne przepisy o wtórnym znaczeniu ${ }^{57}$. Dawał tym samym wyraz tendencji do rozciągnięcia mocy obowiązujących w nim przepisów na dłuższy okres odbudowy. Trzeba przy tym zauważyć, że na równi ze strajkiem traktował on lokaut, co świadczyło o uznaniu oby tych form walki za równouprawnione, jakkolwiek nie było to stanowisko powszechnie akceptowane w praktyce i $\mathrm{w}$ doktrynie.

\section{Uwagi końcowe}

Całość przedstawionych projektów daje wyraz tendencji do ograniczania zatargów zbiorowych przechodzących w fazę bezpośredniej walki i próby sił ${ }^{58}$ oraz do wzmocnienia roli orzeczeń rozjemczych jako źródła zbiorowego prawa pracy. Ta sama tendencja uwidoczniła się w projektowanym unormowaniu układów zbiorowych pracy, w którym położono szczególny nacisk na ich funkcję normatywną i to w zakresie przekraczającym ustalenia dokonywane bezpośrednio przez strony będące ich uczestnikami. W obu tych dziedzinach koncepcje Departamentu zmierzały do stworzenia $\mathrm{w}$ zbiorowych stosunkach pracy podstaw uprzedmiotowionego ładu poprzez akty normatywne, wyrastające wprawdzie ze współdziałania zainteresowanych stron, ale uzyskujące moc prawną w znacznej mierze niezależnie od ich woli, zwłaszcza co do zasięgu ich obowiązywania. Stawiało to pod znakiem zapytania autonomiczny charakter norm zbiorowego prawa pracy. $\mathrm{Z}$ tendencjami tymi harmonizowały natomiast dążenia do konsolidacji ruchu zawodowego, o których była mowa w poprzednim rozdziale.

U podstaw tych idei leżało założenie, że w przyszłej Polsce powstaną przesłanki dla zgodnego wysiłku i współdziałania wszystkich sił społecznych ponad konfliktami klasowymi i związanymi z nimi rozbieżnościami interesów oraz przekonanie, że takie właśnie współdziałanie stanowi konieczny warunek postulowanego skierowania rozwoju społeczno-gospodarczego kraju na nowe tory.

\footnotetext{
${ }^{57}$ Przewidywały one w szczególności upoważnienie Wydziałów Pojednania przy organach administracji pracy do wydawania orzeczeń rozjemczych (art. 45 ust. 1).

${ }^{58} \mathrm{Na}$ uwagę zasługuje w związku z tym definicja zatargu zbiorowego pracy. Został on określony jako „stan sporu między grupami pracowników i pracodawców w sprawie treści układu przyszłego bądź treści układu obowiązującego" (art. 25 ust. 1).
} 


\section{Indywidualne prawo pracy}

\section{Uwagi wstępne}

Indywidualne stosunki pracy nie wymagały w przekonaniu Departamentu tak gruntownej przebudowy podstaw prawnych, jak ustrój pracy i stosunki zbiorowe. Prawo obowiązujące w tym zakresie przed wojną oceniane było na ogół jako społecznie postępowe, jakkolwiek w końcowych latach uległo pogorszeniu, a ponadto często nie było przestrzegane w praktyce. W pracach Departamentu wykrystalizowała się jednak teza, że na „tle wojennych doświadczeń całego narodu wyrosły (także i w tej dziedzinie) nowe idee, dające początek nowym zasadom polityki społecznej”, obejmującej całokształt stosunków pracy. Pociągało to za sobą konieczność może nie tyle „całkowitej przebudowy odpowiednich przepisów”, co jednak ,nadania im nowego oblicza i nowego sensu społecznego" 59 .

$\mathrm{W}$ toku prac podjętych dla przygotowania tych zmian okazało się jednak, że będą one wymagały dość gruntownej przebudowy prawa regulującego indywidualne stosunki pracy i nadania im nowego kształtu legislacyjnego. Dwie kwestie wysunęły się przy tym na czoło jako rozstrzygające o charakterze przyszłego prawa pracy. Były to: postulowana jedność tego prawa w stosunku do ogółu pracowniczego oraz zmiana charakteru stosunku pracy w kierunku wzmacniającym ochronę interesów pracowniczych. W obu tych zakresach istotny wpływ na koncepcję Departamentu wywarły doświadczenia z okresu międzywojennego.

W okresie tym zarysowały się w sytuacji pracowników głębokie linie podziału, których społeczna zasadność musiała budzić uzasadnione wątpliwości. Należał do nich przede wszystkim podział pracowników na fizycznych (robotników) i umysłowych, który ukształtował się na gruncie tradycji i zwyczajów, a częściowo także na podstawie fragmentarycznych regulacji, jakie obowiązywały w państwach zaborczych. Nie bez znaczenie była przy tym odrębność społeczno-kulturalna grupy inteligenckiej, a także jej znaczenie w tworzeniu podstaw polskiej państwowości. Dużą rolę odegrało też powstanie odrębnych związków zawodowych pracowników umysłowych, które okazały się bardzo prężne i wpływowe ${ }^{60}$.

Ten stan zastany i te czynniki zdeterminowały w znacznej mierze treść ustawodawstwa pracy lat dwudziestych i trzydziestych. Nie stworzyło ono wprawdzie podstaw omawianego podziału, usankcjonowało go jednak i przyczyniło się do jego utrwalenia oraz związało z nim daleko idące różnice uprawnień. Takie znaczenie miała już ustawa urlopowa z 1922 r., a następnie dekret o ubezpieczeniu emerytalnym i na wypadek braku pracy dla pracowników umysłowych (1927),

${ }^{59}$ Zasady nowego prawa pracy (maszynopis, s. 1, zbiory W.S.).

${ }^{60}$ Por. M. Święcicki, op. cit., s. 138 oraz J. Hoppe, Wspomnienia, przyczynki, refleksje, Londyn 1972, s. 24 i n. 
a zwłaszcza dwa odrębne dekrety o umowie o pracę (1928), które stworzyły zasadniczo odmienny reżim prawny dla każdej z omawianych grup pracowników ${ }^{61}$.

Kategorię pracowników szczególnie upośledzonych pod względem sytuacji prawnej stanowili w okresie międzywojennym robotnicy rolni. Pierwsza ustawa ich dotycząca została wprawdzie wydana już w 1919 r., była jednak podyktowana potrzebą zapobiegania konfliktom i strajkom, które w rolnictwie mogły mieć dotkliwe skutki gospodarcze. W związku z tym regulowała ona wyłącznie tryb załatwiania zatargów zbiorowych w drodze zawierania tzw. ugód w postępowaniu pojednawczym i wydawania orzeczeń rozjemczych. Brak było natomiast w całym okresie międzywojennym ustawowej regulacji umów o pracę i ochrony pracy robotników rolnych. W niewielkim stopniu znalazł do nich zastosowanie kodeks zobowiązań. Wyłączony został także w stosunku do robotników rolnych tryb rozstrzygania indywidualnych sporów przez sądy pracy ${ }^{62}$.

Na innej zasadzie ukształtowała się odrębność sytuacji prawnej pracowników zatrudnionych w urzędach i instytucjach państwowych, o której uregulowaniu ustawą już w 1922 r. zadecydowała pilna potrzeba stworzenia sprawnego aparatu administracyjnego ${ }^{63}$. Państwową służbę cywilną cechowała, w odróżnieniu od umownych stosunków pracy, większa dyspozycyjność, ale zarazem stabilizacja zatrudnienia i korzystniejszy system emerytalny. Odrębności te, łącznie z trybem przyjmowania do pracy na podstawie nominacji, a nie umowy, sprawiły, że reżim stosunków służbowych grawitował wyraźnie ku prawu administracyjnemu i wyodrębniał się z prawa pracy, nawiązującego do zobowiązaniowych konstrukcji cywilnoprawnych. Znalazło to odbicie w literaturze, a w szczególności w treści podręczników i wydawnictw komentarzowych, które konsekwentnie pomijały służbę cywilną, uznając ją za dziedzinę leżącą poza zakresem prawa pracy ${ }^{64}$.

W pracach programowych Departamentu zarysowała się zdecydowana tendencja zerwania z tymi wszystkimi podziałami. Zdominowała ona koncepcje programowe Departamentu w zakresie prawa pracy, które znalazły główny wyraz w postulacie ,jedności pracowniczej”"65, jakkolwiek dotyczyły również zmiany charakteru stosunku pracy i ulepszenia niektórych innych unormowań. Koncepcje

${ }^{61}$ Szerzej w tej sprawie W. Szubert, Ujednolicenie prawa pracy w polskiej myśli prawniczej lat międzywojennych i okresu wojny, „Państwo i Prawo” 1991, nr 4, s. 27-28.

${ }^{62}$ Ibidem, s. 28.

${ }^{63}$ W. Jaśkiewicz, Studia nad sytuacją prawna pracowników państwowych, Poznań 1961, t. 1, s. 79 in.

${ }^{64} \mathrm{Nie}$ brak jednak publikacji dopatrujących się pewnego pokrewieństwa pomiędzy tymi dziedzinami. Por. w szczególności: Z. Fenichel, Polskie prawo urzędnicze a prawo pracowników najemnych, „Praca i Opieka Społeczna” 1930, nr 4, s. 367, 369, 378; Z. Zaleski, Rola sąów pracy $w$ zakresie realizowania zasad i ksztaltowania wytycznych polityki spolecznej państwa, „Praca i Opieka Społeczna” 1930, nr 1, s. 5 oraz S. Mateja, Tendencje prawa pracy, „Praca i Opieka Społeczna” 1934, nr 4, s. 419 i 421. Z. Zaleski zwracał uwagę na „urzędniczenie stosunku pracy”, natomiast $\mathrm{S}$. Mateja na tendencję do jego upublicznienia i instytucjonalizacji.

${ }^{65}$ Zasady nowego prawa pracy, s. 1. 
Departamentu zmierzające w tych kierunkach znalazły wyraz w opracowaniach o charakterze tezowym, które nie przybrały postaci konkretnych projektów ustawodawczych. Wyrażają one jednak w sposób niedwuznaczny postulowane zmiany przyszłego prawa oraz konkretyzują wnioski w tej materii ${ }^{66}$. Przedstawimy je w zasygnalizowanej wyżej kolejności tematycznej.

\section{Ujednolicenie prawa pracy}

Postulat ujednolicenia prawa pracy, sprowadzający się do usunięcia linii podziału stwarzających nieuzasadnione zróżnicowanie sytuacji prawnej różnych grup pracowniczych, stanowił w programie Departamentu jedną z zasadniczych myśli przewodnich. Należał on do rzędu spraw uznanych przezeń za szczególnie ważne i wymagające zajęcia zdecydowanego stanowiska.

W obliczu przewidywanej po wojnie ,gruntownej reorganizacji podstaw życia zbiorowego" należało, według Departamentu, unikać wszystkiego, „,co społeczeństwo dzieli, przeciwstawia i rozprasza”, przyczyniać się natomiast do „popierania wysiłków i działań umacniających i jednoczących" ${ }^{67}$. Sprzeczne z takim dążeniem byłoby utrzymywanie systemu prawa pracy niejednolitego w swych podstawowych konstrukcjach i opartego na przyjętym z góry podziale pracowników na „sztywno rozgraniczone kategorie" ${ }^{68}$. U podstaw takiego systemu leżała bowiem ,zasada przywileju podtrzymująca nieuzasadnione społeczne rozbicie wśród warstwy pracowniczej”69. Do takich rażących społecznie linii podziału należało w szczególności odmienne unormowanie stosunków pracy robotników i pracowników umysłowych, toteż uznano, że trzeba od niego odstąpić i wprowadzić w miejsce odrębnych regulacji jednolite przepisy dla wszystkich pracowników.

${ }^{66}$ Zachowały się następujące opracowania: (1) Zasady nowego prawa pracy (maszynopis, s. 4); (2) Tezy w sprawie indywidualnego prawa pracy (maszynopis, s. 2); (3) Plan pracy. Obszerne opracowanie mające składać się z 11 części. Zachowało się 8 części obejmujących (podajemy je wraz z kolejnymi numerami, jakimi oznaczono je w Planie: 1. Uwagi ogólne, 2. Ustalenie zagadnień wymagających niejednolitego potraktowania, 5. Urlopy wypoczynkowe, 6. Stosunki pracy na roli, 7. Uwagi na temat stosunku pracy pracowników publicznych, 8. Uwagi w prawie bezpieczeństwa i higieny pracy, 9. Uwagi o pracy młodocianych i kobiet, 11. Czas pracy. Poniżej części te są cytowane z podaniem liczb kolejnych w Planie i pełnego tytułu. Nie zachowały się następujące pozycje objęte Planem: 3. Opracowanie wykazu instytucji prawnych, wchodzących w zakres indywidualnego stosunku pracy, 4. Próba ustalenia i opracowania zagadnień, uzasadniających jednolite ich unormowanie dla wszystkich pracowników oraz 10. Opracowanie poszczególnych instytucji prawnych, wchodzących w zakres stosunku pracy. Wszystkie wymienione opracowania zachowały się w zbiorach W.S. i rodziny M. Święcickiego, częściowo także w AAN, KC PZPR 203/VII-35, t. 3, k. 240-242 i 268-269.

${ }^{67}$ Plan 1: Uwagi ogólne na temat potrzeby reformy przepisów o indywidualnym stosunku pracy, s. 3 .

\footnotetext{
${ }^{68}$ Zasady nowego prawa pracy, s. 1.

${ }^{69}$ Ibidem, s. 1.
} 
Sprawy tej nie należało jednak, według Departamentu, rozwiązywać „po doktrynersku”, w sposób dogmatyczny. Przyjmowano bowiem jako rzecz oczywistą, że zróżnicowanie rodzaju i warunków pracy może dyktować potrzebę pewnej dyferencjacji rozwiązań prawnych. Zróżnicowanie takie powinno jednak być oparte na kryteriach obiektywnych, a nie na apriorycznym niejako założeniu, że pewne kwestie muszą być odmiennie uregulowane ze względu na przynależność danych pracowników do tej lub innej kategorii ${ }^{70}$.

Podział świata pracy na robotników i pracowników umysłowych nie odpowiadał powyższym założeniom, ponieważ „opierał się na poglądach tradycyjnych” i przyjmował za podstawę „zaliczenie do pewnej grupy”, a tym samym sankcjonował i podtrzymywał ,przeciwstawność grup społecznych”. Nie chodziło przy tym o sam fakt, że ,pewne sytuacje życiowe wchodzące w zakres stosunku pracy były różnie rozwiązywane dla pracowników umysłowych i robotników".

Pewne elementy takiej dyferencjacji można byłby bowiem, jak już wspomniano, uznać za uzasadnione, zwłaszcza w odniesieniu do pracowników o szczególnych, wysokich kwalifikacjach. Nieprawidłowość tamtego systemu polegała jednak na tym, że „punktem wyjścia odmiennego uregulowania” uprawnień robotników i pracowników umysłowych były nie obiektywne kryteria związane $\mathrm{z}$ charakterem pełnionej pracy, lecz apriorycznie przyjęty podział ${ }^{71}$.

Przemawiając za ujednoliceniem co do zasady tych uprawnień, należało liczyć się z trudnościami, jakie musiałaby nasunąć tego rodzaju reforma. W Departamencie zdawano sobie sprawę, że nie da się jej konsekwentnie przeprowadzić tak, aby nie pogorszyła sytuacji prawnej pewnego odłamu pracowników. Uważano jednak równocześnie, że nie można cofać się przed taką operacją. „Potrzeba reformy rodzi się zawsze na gruncie niewłaściwych stosunków, nacechowanych jakąś dysproporcją polityczną, społeczną lub gospodarczą. Sprowadzenie koniecznej równowagi następuje z natury rzeczy kosztem pewnego odłamu społeczeństwa, na którego korzyść wytworzyła się owa dysproporcja. I na to nie ma rady"72. Stanowisko Departamentu w tej kwestii było, jak widać, bardzo zdecydowane i bezkompromisowe.

Problemy, o których mowa, mogłyby oczywiście ulec złagodzeniu, gdyby okazało się w jakiejś mierze możliwe „równanie w górę” w postaci zwiększenia uprawnień przysługujących robotnikom. Szanse takie oceniane były jednak przez Departament realistycznie jako bardzo ograniczone. Stąd też wypowiadano się na rzecz operacji zrównującej co do zasady uprawnienia kosztem ich pomniejszenia dla pewnych co najmniej kategorii pracowników umysłowych. Dopuszczano natomiast w razie „konieczności taktyczno-politycznych” częściowe utrzymanie praw nabytych, w formie wydania odpowiednich przepisów przejściowych ${ }^{73}$.

\footnotetext{
${ }^{70}$ Plan 1: Uwagi ogólne..., s. 2-3.

${ }^{71}$ Ibidem, s. 2.

${ }^{72}$ Ibidem, s. 3.

${ }^{73}$ Ibidem.
} 
Uznawano natomiast, że jednolitość regulacji prawnej stosunku pracy nie powinna stać na przeszkodzie dyferencjacji szczegółowych rozwiązań w zależności od warunków i potrzeb związanych z rodzajem wykonywanej pracy. Mogłoby to np. polegać na zróżnicowaniu okresu próbnego w zależności od tego, jaki czas jest w danym rodzaju pracy potrzebny dla sprawdzenia przydatności pracownika, czy też na zróżnicowaniu okresu wypowiedzenia zależnie od szans uzyskania w danym zawodzie nowej pracy, czy wreszcie na ustaleniu różnych terminów wypłaty wynagrodzenia (miesięcznych czy dwutygodniowych) ${ }^{74}$.

Postulując usuwanie nieuzasadnionych linii podziału wśród pracowników, należało też zająć stanowisko wobec upośledzenia robotników rolnych. Z krytyczną oceną Departamentu spotkało się wyłączenie tej kategorii robotników poza obręb ustawodawstwa pracy i oparcie regulacji ich statusu prawnego na umowach zbiorowych i orzeczeniach rozjemczych. Prowadziło to bowiem do koniunkturalnej zmienności obowiązujących norm oraz do nieuzasadnionego zróżnicowania ich treści na różnych obszarach. Stąd też, nie kwestionując w ogóle użyteczności układowej metody regulowania warunków pracy na roli, postulowano, aby podstawowe zagadnienia stosunku pracy zostały unormowane w sposób jednolity i trwały dla wszystkich robotników rolnych na obszarze całego kraju w drodze ustawowej.

W treści tej ustawy powinny natomiast, według Departamentu, znaleźć wyraz odrębności wynikające z samego charakteru pracy na roli i stanowiące realną przesłankę dla rzeczowo uzasadnionej dyferencjacji przepisów prawa pracy, o której była już mowa. Stwierdzenie to miało wpływ na postulowany kształt legislacyjny regulacji stosunku pracy, do czego wypadnie jeszcze powrócićc ${ }^{75}$.

Bliższą uwagę Departamentu przyciągnęła również regulacja sytuacji prawnej funkcjonariuszy państwowych (urzędników), której odrębność została przez Departament zakwestionowana jako niemająca rzeczowych podstaw. Wbrew konstrukcjom przyjętym przed wojną i poglądom rozpowszechnionym w ówczesnej literaturze uznano, że stosunki, w jakich pozostają pracownicy „publiczni” i „prywatni”, wykazują daleko idące podobieństwo. Treścią jednych i drugich stosunków jest bowiem odpłatne pełnienie pracy oraz podporządkowanie pracodawcy z tym tylko, że w odniesieniu do funkcjonariuszy jest nim państwo lub inny związek publicznoprawny.

Uznawano przy tym za nieistotny fakt, że ci ostatni są zatrudnieni na podstawie nominacji, a nie umowy, gdyż po pierwsze w służbie publicznej występowała także liczna kategoria pracowników kontraktowych, a po drugie nominacja staje się skuteczna dopiero po jej przyjęciu, co nadaje służbie publicznej charakter

\footnotetext{
${ }^{74}$ Plan 2: Próba ustalenia zagadnień wchodzacych w zakres indywidualnego stosunku pracy a wymagajacych niejednolitego potraktowania i uwagi wstępne na temat ich rozwiazania, s. 1-3.

${ }^{75}$ Plan 6: Uwagi w sprawie unormowania stosunków pracy na roli. Tytuł ten został uzupełniony następującym tekstem dodanym w nawiasie: „Dozorcy domowi i służba domowa byliby objęci programem ogólnej ustawy o stosunku pracy".
} 
dobrowolny, a więc zbliżony co do istoty do umownego ${ }^{76}$. Dodatkowy argument płynął z ogólniejszego poglądu na charakter stosunku pracy, w którym eksponowano elementy instytucjonalne i znaczenie sytuacji faktycznych, do czego nawiążemy jeszcze w toku dalszych wywodów.

Wychodząc z przedstawionych powyżej założeń, uznawano ostatecznie, że „stosunek pracy pracownika prywatnego i stosunek pracy pracownika publicznego jest stosunkiem tego samego rodzaju" "77 a więc jeden i drugi powinien być uregulowany wspólnymi przepisami. Nie gubiono przy tym z pola widzenia faktu, że niektóre działy służby publicznej i stanowiska stawiają specjalne wymagania i nakładają szczególne obowiązki. Odrębności tego rodzaju mogą uzasadniać potrzebę normowania ich szczególnymi przepisami, czego nie można zresztą wykluczyć również w odniesieniu do niektórych kategorii pracowników „,prywatnych”. Nie podważało to natomiast jednolitości stosunku pracy w jego typowej postaci, $\mathrm{z}$ niezbędnym uwzględnieniem jego najbardziej istotnych składników ${ }^{78}$.

Jednolite unormowanie stosunku pracy wszystkich pracowników, łącznie z funkcjonariuszami państwowymi, nie powinno było, według Departamentu, wbrew podnoszonym niekiedy wątpliwościom, osłabić aparatu państwowego ani odbić się ujemnie na jego sprawności. Przyczyniłoby się natomiast do oparcia go na bardziej stabilnych, powszechnie przyjętych podstawach prawnych i ograniczenia dowolności zmiennych regulacji, odnoszących się do samej służby ${ }^{79}$.

Argumentację tę wzmacniało jeszcze odwołanie się do zarysowujących się przeobrażeń w życiu zbiorowym, nadających nowe znaczenie pojęciu sprawiedliwości społecznej. W obliczu tych przemian wyodrębnienie reżimu prawnego służby publicznej, a tym samym traktowanie „biurokracji publicznej jako odrębnej kasty" byłoby głęboko niewłaściwe, gdyż musiałoby co najmniej wzbudzać podejrzenie o tendencję do stwarzania dla niej uprzywilejowanej pozycji. Odstąpienie od konstrukcji prawnych mogących nasuwać takie skojarzenia zostało w związku z tym uznane przez Departament za probierz zaufania do kierunku polityki społecznej prowadzonej przez państwo ${ }^{80}$.

Należało przy tym zwrócić uwagę na jeszcze jeden element pojmowania podstaw stosunku pracy, znajdujący wyraz w dokumentach Departamentu. Polegał on na uznaniu, że stosunek pracy może powstawać nie tylko na podstawie umowy i innych aktów prawnych, lecz także na skutek działań faktycznych. W związku z tym przyjmowano, iż stosunek pracy jest swoistym stosunkiem faktycznym, który „z mocy prawa staje się stosunkiem prawnym i podlega specjalnym przepisom,

\footnotetext{
${ }^{76}$ Tezy w sprawie indywidualnego stosunku pracy, teza 3 in fine. Plan 7: Uwagi na temat celowości objęcia przepisami ustawy o stosunku pracy pracowników publicznych, s. 1-3.

${ }^{77}$ Ibidem, s. 2.

${ }^{78}$ Ibidem, s. 3.

${ }^{79}$ Ibidem, s. 3-4.

${ }^{80}$ Ibidem, s. 4.
} 
niezależnie od tego, czy przy ustanawianiu tego stosunku podejmowane były jakiekolwiek akty prawne w rodzaju umowy, nominacji, nakazu itp." ${ }^{\text {"1 }}$ Poglądy te dostarczały dalszych argumentów na rzecz nieróżnicowania regulacji i stosunków pracy zależnie od podstawy jego powstania, lecz nadawania jej bardziej ujednoliconej postaci.

Idea jedności pracowniczej dotyczyła w szczególny sposób regulacji stosunku pracy. Znalazła ona jednak wyraz także w innych projektach Departamentu, mających odniesienie do ruchu zawodowego i organizacji świata pracy. Związki zawodowe miały obejmować, zgodnie ze stanowiskiem Departamentu, wszystkich pracowników bez względu na dziedzinę ich pracy i charakter zatrudnienia, w tym również funkcjonariuszy państwowych, których wyodrębnienie $\mathrm{z}$ tego ruchu uznano za „szkodliwy przeżytek”. Przewidywany w stosunku do nich zakaz strajku nie miał być wyróżnikiem ich sytuacji prawnej, postulowano bowiem zastosowanie tego ograniczenia także w stosunku do pracowników zatrudnionych w niektórych przedsiębiorstwach użyteczności publicznej ${ }^{82}$.

Podobne tendencje znalazły odbicie w projektach dotyczących wprowadzenia rad zakładowych. Rady te miały być wewnętrznie jednolite, bez podziału na robotników i pracowników umysłowych, co miało symbolizować „zespolenie kultury i pracy” oraz uwydatniać ,jedność socjologiczną inteligencji kierowniczej i pracy wykonawczej" ${ }^{83}$. Ponadto rady miały działać, z pewnymi odrębnościami, także w urzędach, a więc miały być instytucją o zastosowaniu powszechnym, obejmującym cały świat pracy. Rozstrzygnięcia te dopełniały w sposób istotny koncepcje dotyczące regulacji indywidualnych stosunków pracy. Miały przy tym o tyle większą wagę, że zostały wyrażone w dokumentach, które cechował znacznie większy stopień wykończenia i konkretyzacji.

Przedstawione myśli programowe przesądzały w znacznej mierze o kształcie postulowanej legislacji. Naturalną drogą do ich urzeczywistnienia na gruncie prawa było ,potraktowanie wszystkich pracowników w płaszczyźnie jednej ustawy" ${ }^{\prime 4}$. Miała to być przy tym ustawa o stosunku pracy (a nie o umowie o pracę) regulująca, zgodnie z przedstawionymi powyżej poglądami, różne jego postacie. Ustawa ta miałaby zastąpić odrębne akty prawne dotyczące osobno robotników i pracowników umysłowych, a także przepisy kodeksu zobowiązań o umowie o pracę. Miała ona również objąć funkcjonariuszy publicznych, poza szczególnymi rodzajami służby, wymagającymi odrębnej regulacji ${ }^{85}$.

Wydanie takiej ustawy stanowiłoby doniosły krok prowadzący do ujednolicenia regulacji stosunku pracy „,w jego typowej postaci”" ${ }^{\prime 6}$. Nie wyczerpywa-

\footnotetext{
${ }^{81}$ Ibidem, s. 2.

${ }^{82}$ Uzasadnienie projektu prawa związów zawodowych, s. 7-8.

${ }^{83}$ Uzasadnienie projektu dekretu: Prawo rad zakładowych, s. 7-8.

${ }^{84}$ Plan 1: Uwagi ogólne..., s. 3.

${ }^{85}$ Ibidem, s. 4 oraz Plan 7: Uwagi na temat celowości..., s. 4-5.

${ }^{86}$ Plan 7: Uwagi na temat celowości..., s. 3.
} 
łaby ona jednak wszystkich aspektów tej regulacji w przekroju podmiotowym i przedmiotowym. W pierwszym z tych zakresów zarysowywała się odmienność sytuacji prawnej robotników rolnych. Departament postulował wprawdzie ustawowe uregulowanie tej sytuacji na zasadach ogólnie przyjętych w odniesieniu do wszystkich pracowników. Miał jednak z drugiej strony na uwadze liczne odrębności w ukształtowaniu różnych aspektów pracy na roli, nad którymi trudno byłoby przejść do porządku, a których unormowanie we wspólnej ustawie uczyniłoby ją niespójną i nadmiernie obciążyłoby jej treść. Z tych też głównie techniczno-legislacyjnych względów, wypowiedział się ostatecznie za unormowaniem stosunku pracy na roli osobną ustawą ${ }^{87}$.

$\mathrm{W}$ aspekcie przedmiotowym zarysowywała się również w Departamencie tendencja wyodrębnienia niektórych unormowań w osobne ustawy. Dotyczyło to w szczególności przepisów o pracy młodocianych i kobiet oraz o czasie pracy. W pierwszym przypadku - wskazywano na szczególnie mocno zarysowaną odmienność sytuacji tej kategorii pracowników oraz swoisty charakter materii wymagających w stosunku do nich unormowania ${ }^{88}$. W drugim - na ogólniejsze znaczenie społeczno-gospodarcze regulacji czasu pracy, wykraczające poza stosunki między pracodawcami i pracownikami oraz na obszerność tej materii i niezbędną dyferencjację szczegółowych unormowań ${ }^{89}$. Uznano natomiast za celowe włączenie do ogólnej ustawy o stosunku pracy przepisów w przedmiocie urlopów wypoczynkowych ${ }^{90}$ oraz bezpieczeństwa i higieny pracy, pomimo że ta ostatnia materia wymagała również szczegółowej i zróżnicowanej regulacji aktami wykonawczymi ${ }^{\text {11 }}$.

Wychodząc z przedstawionych powyżej, nie w pełni przekonywających przesłanek, zmierzano ostatecznie do scalenia przepisów prawa pracy wprawdzie nie w jednej ustawie, ale w „kilku syntetycznych aktach prawodawczych”, dotyczących indywidualnego prawa pracy, co miało stanowić „doniosły krok w kierunku właściwej kodyfikacji”’2. Te ostatnie dążenia odnosiły się wprawdzie do uporządkowania i scalenia przepisów prawa pracy, a nie ich treści. Nie ulega jednak wątpliwości, że zamierzona kodyfikacja prawa pracy służyłaby nie tylko formalnemu uporządkowaniu przepisów tego prawa, lecz także ich merytorycznemu ujedno-

${ }^{87}$ Chodziło także o większą dostępność i zrozumiałość tej regulacji dla robotników rolnych, co wydawało się łatwiejsze do osiągnięcia w razie wyodrębnienia jej w osobnej ustawie, dotyczącej wyłącznie tej kategorii pracowników. Por. Plan 6: Uwagi w sprawie unormowania stosunków na roli..., s. 4

${ }^{88}$ Plan 9: Uwagi w sprawie pracy młodocianych $i$ kobiet, s. 1-2.

${ }^{89}$ Plan 11: Przepisy o czasie pracy a projekt ustawy $i$ stosunku pracy, s. 1-3.

${ }^{90}$ Plan 5: Uwagi na temat potrzeby reformy przepisów o urlopach wypoczynkowych i zagadnienie wtaczenia ich do ustawy o stosunku pracy, s. 4-5.

${ }^{91}$ Plan 8: Uwagi w sprawie celowości utrzymania odrębności przepisów o higienie i bezpieczeństwie pracy, s. 1-2.

${ }^{92}$ Zasady nowego prawa pracy, s. 4. 
liceniu. Warto $\mathrm{w}$ związku z tym przypomnieć, że idea podjęcia przygotowań do kodyfikacji prawa pracy była żywa również wśród prawników polskich w okresie międzywojennym ${ }^{93}$.

\section{Instytucjonalizacja stosunku pracy}

Postulat instytucjonalizacji stosunku pracy był głęboko zakotwiczony w ideach programowych Departamentu i stanowił jedną z jego naczelnych tez. Aby zrozumieć jego istotny sens i znaczenie, trzeba przypomnieć, że był on uwarunkowany sumą przedwojennych doświadczeń, od których chciano stanowczo się oderwać, zajmując wobec nich negatywne, niekiedy nadmiernie wyostrzone stanowisko. Dotyczyło ono w danym przypadku układu sił na rynku pracy, w którym pozycja pracownika była na ogół bardzo słaba.

Obowiązujące wówczas prawo pracy miało wprawdzie charakter ochronny i ustanawiało pewne minima uprawnień pracowniczych (np. co do czasu pracy, wymiaru urlopów wypoczynkowych, długości okresu wypowiedzenia umowy), których indywidualne umowy o pracę nie mogły skutecznie naruszać. W praktyce jednak zasady te były nader często łamane, do czego przyczyniało się bezrobocie, które stawiało pracowników w niekorzystnej pozycji i skłaniało ich do uległości wobec pracodawców.

Jeszcze gorzej przedstawiała się sprawa wynagrodzenia za pracę i różnych świadczeń należnych od pracodawców, która jako materia pozaustawowa, regulowana jedynie układami zbiorowymi pracy o zmiennej treści i dość wąskim zakresie działania, korzystała praktycznie $\mathrm{z}$ bardzo wątłej ochrony prawnej. W tym stanie rzeczy, przy wzięciu jeszcze pod uwagę silnego przyrostu naturalnego i nacisku migracji ze wsi do miast, pracownik znajdował się w istocie we władzy swego aktualnego pracodawcy, a sama praca upodobniała się do towaru, którego cena (w szerokim tego słowa znaczeniu) zależała od zmiennych i na ogół niekorzystnych dla pracowników sytuacji rynkowych.

Zasadniczo zmiana tego stanu rzeczy była jedną z głównych idei programowych Departamentu. W tym kierunku zmierzały opracowane przezeń założenia przyszłej polityki zatrudnienia, a także konsolidacji ruchu zawodowego, tak aby mógł on skuteczniej bronić pracowników, występując jako podmiot akcji i porozumień zbiorowych. Niezależnie od tego uważano jednak za niezbędną zmianę reżimu indywidualnych stosunków pracy, polegającą na pewnym usztywnieniu

\footnotetext{
${ }^{93}$ Por. Przedmowe od Redakcji w nr 1 „Przeglądu Prawa Pracy" (1938) inaugurującym wydawanie tego czasopisma (s. 2) oraz informację podaną w tymże czasopiśmie (1939, nr 6) o przygotowywanym na 3-6 IX 1939 Zjeździe Prawników Polskich w Gdyni, na którym jednym z tematów dyskusji miało być „Zagadnienie kodyfikacji prawa pracy” reformowane przez Z. Zaleskiego.
} 
podstawowych elementów ich treści i uniezależnieniu ich w ten sposób od zmiennych układów sił.

W tym ostatnim zakresie wydawało się zbyt słabe wszystko to, co miało charakter wyłącznie umowo-zobowiązaniowy, ponieważ umowa ulegała często dyktatowi silniejszego kontrahenta, a pracownicy gotowi byli zbyt łatwo zobowiązywać się do pracy na bardzo dla nich niekorzystnych, krzywdzących warunkach. Najwłaściwszą drogą obrony wydawało się w tych okolicznościach oparcie się na przepisach prawa, wyłączającego szkodliwą społecznie wolność umów i ustanawiającego bezpośrednio określony porządek prawny w dziedzinie stosunków pracy. Prawo takie powinno, w opinii Departamentu, oderwać się od zasad prawa prywatnego (cywilnego) i uzyskać charakter publicznoprawny.

W tym kontekście zrozumiałe stają się sformułowania zawarte w dokumentach Departamentu stwierdzające, że „zasada wolnej gry sił, dająca przewagę stronie gospodarczo silniejszej, była źródłem systemu zobowiązaniowego przy normowaniu stosunku pracy", natomiast na przyszłość polityka społeczna powinna zmierzać do „zniesienia formy zobowiązaniowej w dziedzinie indywidualnego stosunku pracy i nadania mu, w oparciu o przepisy bezwzględnie obowiązujące, cech specjalnej instytucji prawa"94.

Tę samą myśl wyraził inny dokument słowami, że w zakresie indywidualnego stosunku pracy należy dążyć do „ograniczenia swobody stron i nadania stosunkowi pracy formy bardziej sztywnej, niemal typowej”. Potrzeba takiego ,uproszczenia i zracjonalizowania stosunków indywidualnych" wiązana była z postulatem gospodarki planowej oraz ,przebudowy od podstaw życia zbiorowego”. A w rozwinięciu tej myśli dalej czytamy, że „pod wpływem tej tendencji muszą zniknąć dotychczasowe przepisy o umowie o pracę jako przepisy o charakterze zobowiązaniowym”, a „na ich miejsce muszą powstać przepisy o stosunku pracy, w których niemal wyłącznie będą dominować pierwiastki publicznoprawne" 95 .

W sformułowaniach tych można się dopatrzeć odbicia myśli Stefana Matei, który w swych pracach, nawiązując do francuskiego prawnika Maurice'a Hauriou, skłonny był uznawać stosunek pracy nie tyle za konstrukcję umowną, co za instytucję, a więc ,gotową sytuację prawną" o charakterze trwałym i ukształtowaną przez ogólny porządek prawny, na której treść jednostka nie ma właściwie wpływu, należy bowiem do niej jedynie decyzja o wstąpieniu w tę sytuację (i do tego sprowadza się w istocie element umowny tej konstrukcji $)^{96}$.

Stanowisko Departamentu nie podważało, jak wynika z powyższego, zasady wolności pracy, której istotny sens polega, jak wiadomo, nie tylko na swobodnym wyborze miejsca zatrudnienia, lecz także na uzależnieniu powstania stosunku pracy (oraz jego trwania) od woli pracownika. Nie osłabiało ono również w żadnej

\footnotetext{
${ }^{94}$ Zasady nowego prawa pracy, s. 3.

${ }^{95}$ Plan 1: Uwagi ogólne..., s. 3.

${ }^{96}$ Plan 2: Próba ustalenia zagadnień..., s. 1-2.
} 
mierze możności dochodzenia roszczeń ze stosunku pracy na drodze sądowej, i to przed sądami wyspecjalizowanymi w rozstrzyganiu tego rodzaju spraw przy udziale czynnika społecznego (ławnicy), co zapewniało wnikliwe rozpatrywanie spraw i niezbędny obiektywizm.

Należy również zauważyć, że „odrzucając [...] zasadę [wolnej gry sił] w zakresie podstawowych uprawnień pracownika ze stosunku pracy" na gruncie indywidualnych rokowań, Departament dopuszczał ją natomiast, jakkolwiek w ograniczonej postaci „na gruncie kształtowania płac, gdzie występują przeciwko sobie nie poszczególny pracodawca i pracownik, lecz odpowiednie siły zbiorowe" ${ }^{97}$. Do wzmocnienia tych sił po stronie pracowników miała się natomiast przyczynić w koncepcji Departamentu konsolidacja związków zawodowych (por. rozdział III).

Postulaty Departamentu dotyczące instytucjonalizacji stosunku pracy zmierzały zatem w ogólnym swym wyrazie do wzmocnienia ochrony interesów i podniesienia godności pracowników przez wyzwolenie ich z degradujących społeczną wartość pracy zależności rynkowych. Pomimo to, sama koncepcja owej instytucjonalizacji nie wydaje się w pełni przekonywająca i może budzić wątpliwości, do których powrócimy w zakończeniu niniejszego rozdziału.

\section{Inne problemy}

Prace koncepcyjne Departamentu dotyczyły, poza wskazanymi powyżej podstawowymi kwestiami, różnych instytucji prawa pracy, rozpatrywanych pod kątem ulepszenia ich regulacji. Istotną rolę odgrywało przy tym poszukiwanie właściwych zasad dyferencjacji rozwiązań prawnych, mającej za punkt wyjścia obiektywne różnice dotyczące charakteru, rodzaju i warunków pełnionej pracy.

$\mathrm{Z}$ tego punktu widzenia rozpatrywano, o czym była już mowa, pożądaną regulację okresu próbnego i okresu wypowiedzenia stosunku pracy, przyjmując w obu tych przypadkach celowość podziału pracowników na dwie kategorie w zależności od posiadanych przez nich kwalifikacji, mających wpływ na czas potrzebny do stwierdzenia ich przydatności oraz do znalezienia nowego zajęcia, po zwolnieniu z pracy dotychczas wykonywanej ${ }^{98}$.

Pod tym samym kątem rozważano zróżnicowanie wymiaru urlopów wypoczynkowych, wypowiadając się za preferencjami dla pracowników pełniących prace ciężkie i szkodliwe dla zdrowia oraz dla młodocianych, w formie przyznania im dodatkowych urlopów poza ogólnie obowiązującym wymiarem. Co do pracowników w starszym wieku uznano natomiast, że prawo do dodatkowego urlopu musiałoby być uzależnione od dłuższego okresu zatrudnienia u tego samego pracodawcy. Urlopy zdrowotne mogłyby natomiast być wprowadzone jako

\footnotetext{
${ }^{97}$ Zasady nowego prawa pracy, s. 3.

${ }^{98}$ Plan 2: Próba ustalenia zagadnień..., s. 1-2.
} 
instytucja odrębna od urlopów wypoczynkowych, powiązana raczej ze świadczeniami ubezpieczenia społecznego 99 .

Uwagę Departamentu przyciągały również zagadnienia prawo-organizacyjne (a w pewniej mierze także finansowe) akcji bezpieczeństwa i higieny pracy. Punkt ciężkości tej akcji widziano w zakładzie pracy; dużą rolę przypisywano jednak również zrzeszeniom branżowym. Wysunięto też koncepcję powołania ogólnopolskiego zrzeszenia bezpieczeństwa i higieny pracy, którego podstawę organizacyjną miały stanowić izby przemysłowo-handlowe, rzemieślnicze i rolnicze, a także izby pracy oraz organizacje techniczne i instytucje ubezpieczenia społecznego. Zrzeszenie to miałoby być ,przymusowym związkiem prawa publicznego", powołanym do koordynowania całokształtu działań na polu bezpieczeństwa i higieny pracy oraz nadawania mu jednolitego kierunku. Do zadań jego miało należeć wykonywanie inspekcji technicznej w zakresie BHP. Równocześnie postulowano rewizję wymiaru składek na ubezpieczenie od wypadków przy pracy w kierunku większego ich zróżnicowania, w zależności od zaangażowania się przedsiębiorstw w akcję bezpieczeństwa i higieny pracy, a nie od kształtowania się obiektywnego ryzyka wypadkowości, uwarunkowanego charakterem danej gałęzi pracy ${ }^{100}$.

Niezależnie od tego Departament wypowiadał się w sprawie włączenia regulacji prawnej różnych materii $\mathrm{w}$ ramach ustawy o stosunku pracy bądź unormowania ich w osobnych aktach normatywnych (ustawach). Sprawę tę omówiono w części niniejszego rozdziału poświęconej ujednoliceniu prawa pracy, wobec czego nie ma potrzeby do niej powracać. Wydaje się natomiast celowe podsumowanie całości naszych spostrzeżeń dotyczących postulatów Departamentu w sprawie indywidualnego prawa pracy.

\section{Uwagi końcowe}

Koncepcje Departamentu dotyczące indywidualnego prawa pracy kształtowały się jak gdyby w cieniu prac nad instytucjami ustroju i zbiorowych stosunków pracy. W związku z tym zostały słabiej zaawansowane i nie doprowadziły do przygotowania projektów konkretnych rozwiązań prawnych. Pomimo to ogólny kierunek zmian postulowanych przez Departament zarysował się wyraźnie, przy czym wiele z nich harmonizowało z przedwojennymi dążeniami klasowych związków zawodowych i postępowej myśli prawniczej.

Dotyczy to w szczególności postulatu ujednolicenia prawa pracy, rozumianego jako odejście od dyferencjacji dyskryminującej pewne grupy pracowników,

\footnotetext{
${ }^{99}$ Plan 5: Uwagi na temat potrzeby reformy przepisów o urlopach wypoczynkowych..., s. 1-3.

${ }^{100}$ Dokument (bez tytułu) dotyczący akcji bezpieczeństwa i higieny pracy (maszynopis, stron 6, zbiory rodziny M. Święcickiego).
} 
W szczególności robotników w porównaniu z pracownikami umysłowymi i robotników rolnych w porównaniu z zatrudnionymi poza rolnictwem. Stanowisko zajęte przez Departament w tej materii jest tym bardziej przekonywające, że nie odrzuca w ogóle dyferencjacji praw i obowiązków pracowniczych, lecz żąda oparcia jej wyłącznie na kryteriach rzeczowych, związanych z rodzajem i warunkami pełnionej pracy i cechami osobistymi pracowników (płeć, wiek).

Pozytywnie należy również ocenić koncepcję opracowania małego kodeksu w postaci ustawy o stosunku pracy, która mogłaby służyć zarówno ujednoliceniu, jak i uporządkowaniu przepisów prawa pracy z dużą korzyścią dla ugruntowania praworządności w tej dziedzinie. Wątpliwości może już natomiast budzić zakres przedmiotowy postulowanej ustawy, a zwłaszcza wyłączenie z niej niektórych materii, jakich charakter nie wymaga $\mathrm{w}$ istocie osobnej regulacji (czas pracy, ochrony pracy kobiet i młodocianych).

Kontrowersyjny charakter ma również propozycja włączenia do powszechnego prawa pracy służby państwowej, ze względu na szczególny charakter i rygory związane z jej pełnieniem, a także rolą w wypełnianiu zadań państwa. Okoliczności te sprawiają, że służba państwowa korzysta w znacznej większości krajów z odrębnego statusu. Na takie też rozwiązanie zdecydowano się w ostatnich latach w Polsce, pomimo że poprzednio dążono do zatarcia różnicy między sytuacją prawną urzędników i pozostałych pracowników, przede wszystkim przez odebranie niektórych przysługujących im dawniej przywilejów (nieusuwalność, odrębny system emerytalny) ${ }^{101}$.

Wysunięty przez Departament postulat ,instytucjonalizacji” stosunku pracy był natomiast uwikłany w nieporozumienia, jakie wyrosły na tle dawnych sporów wokół charakteru prawa pracy jako nowej gałęzi prawa, wyrosłej na pograniczu prawa cywilnego i administracyjnego, z czym wiązało się zapożyczenie pewnych rozwiązań z każdej z tych gałęzi. Wypowiadając się przeciwko wolnej grze sił na rynku pracy, upodabniającej pracę ludzką do towaru, odrzucano zarazem wszystko to, co w konstrukcjach prawnych zdawało się ten układ symbolizować, a więc więź zobowiązaniową powstającą $\mathrm{w}$ drodze umowy o pracę.

Skuteczne antidotum wobec tego stanu rzeczy upatrywano w ukształtowaniu stosunków pracy jako instytucji, której elementy byłyby zakotwiczone bez reszty w porządku publicznoprawnym, określając ściśle obowiązki pracowników i pracodawców wobec siebie i wobec państwa. Nie uwzględniono przy tym faktu, że nadanie przepisom prawa pracy mocy bezwzględnie obowiązującej nie musi bynajmniej przekreślać zobowiązaniowego charakteru stosunku pracy ani podważać roli umowy jako jego źródła.

Co więcej, takie właśnie uwydatnienie charakteru stosunku pracy jako dobrowolnie przyjętego zobowiązania zawiera w sobie duże wartości moralne i podnosi

${ }^{101}$ W szczególności przez ustawę z 16 IX 1982 r. o pracownikach urzędów państwowych (Dz. U. 1982, nr 31, poz. 214). 
godność człowieka pracy oraz stwarza istotne przesłanki dla obrony jego praw. Doświadczenia lat powojennych przyczyniły się w znacznym stopniu do potwierdzenia tych sądów ${ }^{102}$.

Postulowana ,instytucjonalizacja stosunku pracy” nie musiała zatem bynajmniej oznaczać odrzucenia „form zobowiązaniowych”, lecz jedynie konsekwentne oparcie regulacji tego stosunku na normach prawa bezwzględnie obowiązującego oraz stworzenie przesłanek dla przestrzegania go w praktyce. Pierwsze z tych założeń (bezwzględnie obowiązująca moc prawa pracy) zostało spełnione już przed wojną, skoro prawu temu nadano charakter ius cogens, nienaruszalnego w drodze umów, zwłaszcza na niekorzyść pracownika. Zabrakło natomiast wówczas skutecznych gwarancji przestrzegania prawa pracy w praktyce. Słusznie więc Departament postulował ich wzmocnienie poprzez zmianę sytuacji pracowników na rynku pracy (likwidację bezrobocia) oraz w drodze konsolidacji ruchu zawodowego i stworzenia podstaw nowego ustroju pracy.

Ewolucja prawa pracy poszła wszędzie w kierunku bezpośredniego regulowania treści stosunku pracy przez prawo, co ogranicza w tym zakresie coraz bardziej rolę umowy (sprowadzając ją często do tzw. umowy przystąpienia). Umowa pozostaje jednak podstawową instytucją, poprzez którą dokonuje się wstępowanie w stosunki pracy i występowanie z nich, w warunkach zapewniających wolność pracy. Równocześnie ulega wzmocnieniu rola organów państwowych, sprawujących nadzór nad przestrzeganiem prawa pracy, w czym znajduje wyraz jego charakter ,publicznoprawny”. W tym też sensie, abstrahując od werbalnych nieścisłości mogących być źródłem nieporozumień, koncepcje Departamentu postulowały trafnie kierunek rozwoju prawa pracy, który znalazł potwierdzenie w późniejszym doświadczeniu.

Na uwagę zasługują również propozycje Departamentu, dotyczące ulepszenia regulacji niektórych instytucji prawa pracy, jakkolwiek nie wszystkie z nich są w pełni przekonywające, a przede wszystkim nie wyczerpują spraw wymagających rozważenia w tym kontekście i nie zostały bliżej skonkretyzowane. Wynika to jednak z charakteru tych opracowań programowych, które - jak już wspomniano - zostały w tym dziale słabiej zaawansowane niż w innych zakresach prawa i ustroju pracy oraz polityki społecznej, wobec czego sygnalizują raczej kierunki koniecznych reform, aniżeli dają ich pełniejsze rozwinięcie.

${ }^{102}$ Por. W. Szubert, O charakterze prawnym stosunku pracy, „Państwo i Prawo” 1964, nr 7, s. $81 \mathrm{in.}$ 



\section{Część druga}

\section{Ubezpieczenia spoleczne}

\section{Uwagi ogólne}

Ubezpieczenia społeczne stanowiły niezmiernie ważne ogniwo prac koncepcyjnych Departamentu. Złożyło się na to wiele powodów. Doniosłe znaczenie tej instytucji ze względu na potrzeby ludzi pracy uzasadniało potrzebę skupienia na niej szczególnej uwagi. Przedwojenny rozwój ubezpieczeń społecznych nasuwał wiele problemów wymagających zajęcia wobec nich stanowiska. Przyszły kształt tej instytucji tworzył istotny element postulowanego obrazu polityki społecznej, ściśle powiązany z innymi jej zakresami, stanowiącymi przedmiot zainteresowań Departamentu.

Równocześnie $\mathrm{w}$ dziedzinie ubezpieczeń społecznych nabierały szczególnego znaczenia problemy okresu bezpośrednio powojennego. Instytucja ta, jako udzielająca masowo świadczeń osobom pozbawionym innych środków, nie mogła nawet na krótki czas zawiesić swej działalności, tym bardziej że należało przewidywać, iż sytuacja tych osób w końcowym okresie okupacji i w dniach przełomu stanie się wyjątkowo trudna. Działalność ta wymagała przy tym od razu oparcia na nowych zasadach prawnych, w celu oderwania się od porządku okupacyjnego, który wprowadził do niej wiele zniekształceń godzących w żywotne interesy społeczeństwa polskiego, a po części sprzecznych nawet z samą istotą ubezpieczenia społecznego. Chodziło również o to, aby regulacja bezpośrednio powojenna była pozbawiona cech przypadkowości i torowała od początku drogę przyszłym trwałym rozwiązaniom. Ważne było bowiem nie tylko przywrócenie normalnego funkcjonowania ubezpieczenia społecznego i odbudowanie jego zrębów organizacyjnych i zasobów finansowych, lecz także poddanie systemu istniejącego przed wojną przebudowie w kierunku zgodnym z ogólnymi założeniami polityki społecznej, planowanymi na przyszłość.

W tym stanie rzeczy prace dotyczące okresu bezpośrednio powojennego nabierały szczególnego znaczenia, a równocześnie wiązały się ściśle z pracami koncepcyjnymi obliczonymi na dalszą metę. Przyniosły one w efekcie projekt dekretu 
o tymczasowym uporządkowaniu stanu prawnego w dziedzinie ubezpieczeń społecznych (którego tekst zachował się jedynie w części) wraz z uzasadnieniem (w paru wersjach) i tezami odnoszącymi się w części ogólnej również do rozwiązań przyszłościowych. W omówieniu poniższym skupimy przede wszystkim uwagę na koncepcjach określających podstawowe kierunki przyszłego rozwoju ubezpieczeń społecznych, a w dalszej kolejności zajmiemy się opracowaniami dotyczącymi okresu przejściowego.

\section{Główne kierunki ubezpieczeń społecznych}

Myśli o pożądanym kształcie ubezpieczenia społecznego w przyszłej Polsce wynikały bezpośrednio z ogólniejszych założeń dotyczących linii rozwojowych polityki społecznej. Związek ten miał przy tym głębsze podstawy. Skoro bowiem liczono się z potrzebą ,powszechnej mobilizacji wszystkich sił w kraju”, nie tylko dla usunięcia zniszczeń wojennych, lecz także dla przezwyciężenia jego gospodarczego i kulturalnego zacofania', postulując w związku z tym ,uaktywnienie świata pracy, jego woli i wysiłku na rzecz zbiorowych zadań” oraz przewidując, że „konieczny wysiłek inwestycyjny nakazywać będzie wyrzeczenia w zakresie bezpośredniego spożycia" ${ }^{2}$, to należało równocześnie obmyślić system działań sprzyjających kształtowaniu się takich postaw.

Istotną rolę do odegrania $\mathrm{w}$ tej dziedzinie miała polityka zatrudnienia i płac, jak również instytucje składające się na postulowany ustrój pracy. Była o tym mowa w poprzednich rozdziałach. Chodziło jednak również o „wytworzenie atmosfery moralnej wspólnoty, w której powszechności wysiłku towarzyszyć musi zabezpieczenie wszystkim sprawiedliwego zaspokojenia podstawowych potrzeb"3, a te stwierdzenia prowadziły już bezpośrednio do zadań ubezpieczenia społecznego, które z natury rzeczy powołane jest do pokrywania tych potrzeb na zasadzie zorganizowanej, zbiorowej przezorności. Prace Departamentu zmierzały do określenia warunków, jakie powinny spełniać ubezpieczenia społeczne, aby sprostać powyższemu zadaniu.

Warunki te dotyczyły przede wszystkim zakresu osobowego ubezpieczeń społecznych, który w okresie międzywojennym był niepełny i nacechowany wewnętrznymi liniami podziału. Na przyszłość postulowano usunięcie tych wszystkich ograniczeń i zróżnicowań. System ubezpieczeń społecznych powinien objąć, na jednakowych zasadach zarówno pracowników umysłowych, jak i robotników (którzy przed wojną byli upośledzeni w uprawnieniach świadczeniowych), w tym także robotników rolnych (którzy przed wojną korzystali z ubezpieczenia

\footnotetext{
'US Wytyczne, teza 1.

${ }^{2}$ Ibidem, teza 2.

${ }^{3}$ Ibidem, teza 2.
} 
społecznego tylko na niektórych obszarach kraju). Do systemu tego powinni być włączeni również funkcjonariusze służby państwowej i samorządowej oraz pracownicy banków państwowych i przedsiębiorstw, którzy przed wojną byli objęci tzw. systemami zastępczymi na korzystniejszych warunkach. Utrzymywanie tego rodzaju odrębności zostało bowiem uznane za sprzeczne z zasadą solidarności całego świata pracy w obliczu zdarzeń losowych, zagrażających jednakowo wszystkim pracującym ${ }^{4}$.

Z tych samych motywów postulowano uchylenie przepisów, przewidujących wyłączenie z zakresu ubezpieczenia społecznego ze względu na wyższe zarobki, co stanowiło przed wojną pewnego rodzaju przywilej zamożniejszych pracowników umysłowych, którzy nie czuli się zainteresowani ochroną zapewnianą przez ubezpieczenia na wypadek choroby i nie chcieli w związku z tym ponosić ciężaru składek. Ubezpieczenie społeczne miało ostatecznie rozciągać się na cały świat pracy zależnej, przechodząc do porządku nad dzielącymi go poprzednio liniami podziału i sprowadzając wszystkie podstawowe rozwiązania dotyczące składek i świadczeń do pożądanej jedności.

W dalszej przyszłości przewidywano jeszcze pełniejsze urzeczywistnienie „zasady solidarności całego pracującego społeczeństwa” przez objęcie ubezpieczeniem także rzemieślników, kupców i innych osób samodzielnie zarobkujących, jak również osób uprawiających wolne zawody, co miałoby ewentualnie być uzależnione od decyzji reprezentujących te grupy społeczne korporacji publicznoprawnych (w ramach samorządu społeczno-gospodarczego) ${ }^{5}$. Nie rozważano już natomiast bliżej odrębności, jakie musiałyby cechować to ubezpieczenie. Rolnicy indywidualni mieli być objęci ubezpieczeniem po przeprowadzeniu reformy rolnej i wykrystalizowaniu się nowego ustroju rolnego.

Poza ubezpieczeniem powszechnym o charakterze przymusowym zamierzano dopuścić możliwość dobrowolnego ubezpieczenia się przez osoby z kręgu pozapracowniczego, niewłączone do ubezpieczenia decyzją odpowiedniej korporacji, jak również kontynuowanie ubezpieczenia przez osoby, które przestały mu obowiązkowo podlegać7. W tym zakresie trudno było jednak oczekiwać poważniejszych efektów, na co wskazywała praktyka stosowania podobnych przepisów obowiązujących w okresie międzywojennym.

Postulowane scalenie ubezpieczenia społecznego nie dotyczyło systemów dodatkowych, a w szczególności ubezpieczenia górniczego, które miało nadal zachować swą odrębność i być administrowane także w przyszłości przez osobną samorządną instytucję, przy czym postulowano skupienie tych zadań w Spółce

${ }^{4}$ Ibidem, teza 9.

${ }^{5}$ Ibidem, teza 10; Tezy dotyczace ubezpieczeń, teza 3c; Wytyczne projektu powszechnych ubezpieczeń społecznych, teza 3.

${ }^{6}$ Wytyczne projektu..., teza 4.

${ }^{7}$ Tezy dotyczace ubezpieczeń, tezy 4-5. 
Brackiej w Tarnowskich Górach ${ }^{8}$. Przewidywano natomiast zniesienie wszelkich odrębności ubezpieczeń społecznych na Górnym Śląsku (które utrzymały się do końca okresu międzywojennego)9.

Pod względem przedmiotowym system ubezpieczenia społecznego miał obejmować w zasadzie nadal te same ryzyka, co przed wojną, a więc ryzyka: choroby, macierzyństwa, wypadku przy pracy, inwalidztwa, starości i śmierci ubezpieczonego. Przewidywano też utrzymanie ubezpieczenia na wypadek bezrobocia z tym, że miało ono być wyodrębnione pod względem organizacyjnym, podobnie jak przed wojną, z systemu ubezpieczenia scalonego i powiązane z organami polityki zatrudnienia. Rolę tych organów określono przy tym lapidarnie stwierdzając, że „zasadą jest zapewnienie pracy, wyjątkiem zasiłek”. Nie opracowano bliżej koncepcji zasiłków rodzinnych, jakkolwiek znaczenie tych świadczeń, zwłaszcza w okresie przejściowym, było mocno podkreślane w tezach dotyczących płac. Postulowano natomiast wprowadzenie dodatków rodzinnych do rent $\mathrm{z}$ tytułu inwalidztwa i starości.

Bliższą uwagę poświęcił Departament konstrukcji świadczeń ubezpieczeniowych, w szczególności długoterminowych (rent), wypowiadając się za określoną koncepcją roli i zasad wymiaru tych świadczeń. Stanowisko zajęte przez Departament w tej dziedzinie wynikało z ogólniejszych założeń wyrażonych następującymi słowami: „Kto pracował na rzecz zbiorowości, winien mieć przez zbiorowość zapewniony byt $\mathrm{w}$ razie przejściowej lub stałej niezdolności do pracy. Winien być wolny od konieczności bytowania jako ciężar dla swego otoczenia, tak jak ten, kto pracuje, winien być wolny od ciężaru utrzymywania swych niezdolnych do zarobkowania krewnych" ${ }^{10}$. Z założeń tych wywodził się z kolei postulat ,zapewnienia wszystkim pracującym niezbędnych, lecz realnych środków na pokrycie potrzeb wywołanych wypadkiem losowym na podstawie najszerszej solidarności społecznej" ${ }^{11}$. Oznaczało to, innymi słowy, koncepcję określenia poziomu i zasad wymiaru świadczeń długoterminowych w taki sposób, aby zapewniały one godziwe minimum, ale równocześnie nie wykraczały „ponad pewną średnią potrzeb"

Rolę ubezpieczenia powszechnego zamierzano zatem sprowadzić do zagwarantowania świadczeń o dość wyrównanym poziomie, niezależnym od poprzednio pobieranych zarobków, które miałyby na podobieństwo systemów planowanych w tym czasie na Zachodzie (plan Beveridge'a) zapewnić powszechną wolność od niedostatku, nie obiecując natomiast utrzymania poziomu życia odpowiadającego

\footnotetext{
${ }^{8}$ Uzasadnienie dekretu (kartka), art. 45.

${ }^{9}$ Ibidem, art. 44. Tezy dekretu o tymczasowym uporządkowaniu stanu prawnego wubezpieczeniu społecznym, teza 23.

${ }^{10}$ US Wytyczne, teza 4.

${ }^{11}$ Ibidem, teza 5.

${ }^{12}$ Ibidem, teza 6.
} 
posiadanym poprzednio dochodom. Koncepcja ta miała przy tym dotyczyć nie tylko okresu przejściowego (w którym narzucała się sama przez się ze względu na szczupłość rozporządzanych środków), lecz także została uznana za właściwe rozwiązanie do przyjęcia w przyszłym systemie ubezpieczeniowym. Miał on gwarantować powszechnie godziwe minimum, a zdobycie dodatkowych środków pozostawiano już zaradności indywidualnej i zbiorowej ${ }^{13}$, przy czym ta ostatnia mogła przybrać postać ubezpieczeń dodatkowych, z obowiązkowym udziałem pracodawców w pokrywaniu kosztów ${ }^{14}$.

Nie określono natomiast bliżej zasad, na których miałyby być tworzone ubezpieczenia dodatkowe. $\mathrm{Z}$ niektórych sformułowań wynika, że przystąpienie do nich miałoby być fakultatywne, ale w sensie opcji dokonywanej przez określone zbiorowości (załogi poszczególnych zakładów, pracownicy pewnych działów wytwórczości i usług). Zakładano również podobieństwo tych systemów do dodatkowego ubezpieczenia górniczego ${ }^{15}$.

$\mathrm{Z}$ postulowaną rolą świadczeń ubezpieczenia powszechnego harmonizowały propozycje niektórych dalszych zmian: zwiększenia znaczenia tzw. kwoty podstawowej w wymiarze rent, z pomniejszeniem roli tzw. kwoty wzrostu (którą miałyby zapewniać dopiero w większym wymiarze ubezpieczenia dodatkowe), relatywnego podwyższenia wymiaru dodatków rodzinnych do rent ${ }^{16}$.

Odmienny już charakter miały niektóre inne propozycje dotyczące świadczeń pieniężnych: wprowadzenie odpraw dla osób, które zaprzestały wykonywania pracy przed przebyciem w ubezpieczeniu w tzw. okresie wyczekiwania (dotyczyć to mogło zwłaszcza kobiet w związku z zamążpójściem), dopełnienia świadczeń należnych rodzinie po ubezpieczonym zmarłym przez jednorazową zapomogę pośmiertną, ograniczenia uprawnień do renty wdowiej do sytuacji uzasadnionych wiekiem, inwalidztwem lub obciążeniami rodzinnymi (przed wojną ograniczenia takie obowiązywały jedynie w stosunku do robotników) ${ }^{17}$.

W odniesieniu do świadczeń przysługujących w razie przejściowej niezdolności do pracy postulowano przerzucenie ryzyka krótkotrwałych chorób na pracodawców oraz rozpoczynanie wypłaty zasiłków chorobowych dopiero od ósmego dnia niezdolności ${ }^{18}$. Natomiast po upływie 26-tygodniowego okresu pobierania zasiłku miała przysługiwać ubezpieczonemu renta inwalidzka, z tym że byłoby to jednak uzależnione od przebycia w ubezpieczeniu wymaganego okresu wyczekiwania ${ }^{19}$.

Najpoważniejsze zmiany planowano jednak wprowadzić w stosunku do organizacji pomocy leczniczej, związanej genetycznie z ubezpieczeniem społecznym

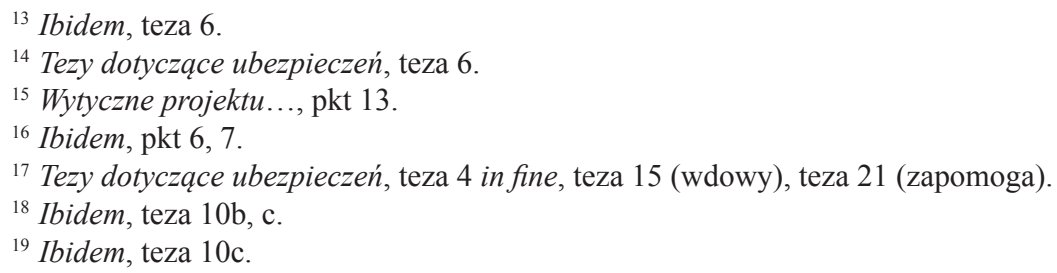


i funkcjonującej w jego ramach w okresie przedwojennym, uznano bowiem, że będzie ona wymagała na przyszłość nowych, znacznie szerszych form organizacyjnych. Ubezpieczenie społeczne spełniło, zgodnie z tym poglądem, w stosunku do uspołecznionego lecznictwa swą historyczną rolę, natomiast dalsze utrzymywanie tego związku byłoby niewłaściwe, jako ograniczające zasięg lecznictwa do kręgu ubezpieczonych, wówczas gdy ważne względy społeczne wymagały rozciągnięcia go na całą ludność kraju, co warunkowało również jego pełną racjonalność i skuteczność.

W związku z tym postulowano stworzenie organizacji, która zapewniałaby „możność objęcia staraniami o najlepszą sprawność fizyczną, higienę umysłową i zdrowostan wszystkich członków społeczeństwa" ${ }^{20}$. Organizacja ta powinna udostępnić „każdemu możność leczenia” na zasadzie bezpłatności oraz rozwinąć szeroką akcję zapobiegawczą, także w stosunku do osób nieodczuwających subiektywnie potrzeby pomocy leczniczejej ${ }^{21}$ Urzeczywistnienie tych zamierzeń wymagało oczywiście spełnienia różnych przesłanek w zakresie rozbudowy odpowiedniej infrastruktury, obsady kadrowej, środków finansowych i innych, wobec czego musiałoby być rozłożone w czasie. Oceniając realistycznie trudności leżące na tej drodze, postulowano jednak, jako „pierwszy krok”, „stworzenie organizacji, która by przejęła wszystkie systemy społecznej służby leczniczej i zapobiegawczej, a więc także lecznictwo ubezpieczeń społecznych, scaliła je, dostosowała i rozbudowała, aby stopniowo objąć w pełnym zakresie całe społeczeństwo swą działalnością"22.

W finansowaniu ubezpieczenia społecznego powinien, według Departamentu, uczestniczyć Skarb Państwa, ze względu na to, że instytucja ta ma służyć „,nie tyle ubezpieczonym jednostkom ile interesowi publicznemu", przy czym interes ten wiązano z głębiej pojętą rolą ubezpieczenia, polegającą na tym, że jest ono „wyrazem moralnego wartościowania pracy i narzędziem wyrównywania dochodu społecznego"²3. Główne źródło finansowania miała jednak stanowić składka łączna na wszystkie rodzaje ubezpieczenia, podzielona w zasadzie po połowie między pracowników a pracodawców i ustalana w takiej wysokości, aby pokrywała bieżące wydatki i pozwoliła na stwarzanie niezbędnych rezerw ${ }^{24}$.

Ta ostatnia kwestia wymagała zajęcia stanowiska wobec złożonej sprawy systemu finansowania ubezpieczenia społecznego, co do której doświadczenia okresu międzywojennego i lat wojny nasunęły wiele wątków do krytycznej refleksji. Stosowany u nas przed rokiem 1939 w ubezpieczeniu długoterminowym system kapitalizacyjny zakładający gromadzenie rezerw, z oprocentowania których miały

\footnotetext{
${ }^{20}$ US Wytyczne, teza 13.

${ }^{21}$ Ibidem, teza 13.

${ }^{22}$ Ibidem, teza 14. Autor tych tez rozwiną szerzej swe koncepcje w wydanej po wojnie książce: J. Piotrowski, Od ubezpieczenia chorobowego do powszechnej stużby zdrowia, Łódź 1948.

${ }^{23}$ US Wytyczne, teza 8.

${ }^{24}$ Wytyczne projektu..., teza 12; Tezy dotyczace ubezpieczeń, teza 30.
} 
być w przyszłości pokrywane świadczenia ubezpieczeniowe w ramach kalkulacji obliczonej „na wieczność”, okazał się już w przedwojennym doświadczeniu zawodny. Wymuszone lokaty funduszów ubezpieczeniowych w papierach wartościowych nie gwarantowały im bowiem niezbędnego bezpieczeństwa, a w warunkach wojennych wartość ich, podobnie zresztą jak niektórych innych lokat, została niemal całkowicie unicestwiona. Należało się wobec tego liczyć z koniecznością odbudowy funduszów ubezpieczeniowych niemal od punktu zerowego, przy czym powrót do dawnego systemu kapitalizacji wydawał się w świetle nagromadzonych doświadczeń niecelowy. Za niewłaściwe uznano jednak również oparcie się na systemie corocznej repartycji, zakładającym wydatkowanie na świadczenia w każdym kolejnym roku całości sum pochodzących ze składek. System ten wymagałby bowiem w ciągu wielu lat corocznego znacznego podnoszenia wymiaru składek, aby sprostać wydatkom na świadczenia dla rosnącej liczby rencistów i emerytów.

Zdecydowano się w związku z tym na przyjęcie systemu pośredniego pomiędzy scharakteryzowanymi wyżej dwiema alternatywami. Przyjęto mianowicie, że repartycja powinna być dokonywana nie corocznie, lecz w ramach okresów pięcioletnich, co ograniczyłoby rozmiary gromadzonych rezerw oraz amortyzowałoby w pewnej mierze nieunikniony wzrost składek, który byłby w tym układzie mniejszy oraz dochodziłby do skutku rzadziej, gdyż również nie co rok, lecz co pięć lat ${ }^{25}$. System ten wymagałby nadal wnikliwej kalkulacji przewidywanych wpływów i wydatków oraz przemyślanej polityki lokat, jednakże problemy z nią związane upraszczałyby się ze względu na mniejszą skalę wielkości tych funduszów i krótsze okresy, w których powinno by było zamykać się ich zużytkowanie.

Departament liczył się z potrzebą takiej kalkulacji opartej na rachunku ubezpieczeniowo-technicznym. Przewidywał w związku z tym zastosowanie odpowiedniej procedury ustalania wymiaru składek na kolejne okresy 5-letnie, której istotne elementy zostały określone w zapisie tezowym następująco: „podstawa - obliczenie aktuarialne, opinia - samorząd społeczno-gospodarczy, wniosek - Rada Zakładu (Ubezpieczeń Społecznych), decyzja - Rada Ministrów”26. Natomiast fundusze ubezpieczeniowe, mające stanowić niezbędne rezerwy, należało lokować w taki sposób, aby zapewniały niezbędny dochód oraz przyczyniały się, bezpośrednio lub pośrednio, do poprawy stopy życiowej ubezpieczonych ${ }^{27}$. Przewidywano też możliwość przeznaczania oszczędności, poczynionych w poszczególnych działach ubezpieczenia społecznego, na świadczenia dodatkowe lub profilaktykę, a także tworzenie specjalnych funduszów na cele wspólne całego systemu ubezpieczenia, w szczególności na lecznictwo, profilaktykę, prace badawcze ${ }^{28}$.

\footnotetext{
${ }^{25}$ Tezy dotyczace ubezpieczeń, teza 27.

${ }^{26}$ Ibidem, teza 31 .

${ }^{27}$ Ibidem, teza 33.

${ }^{28}$ Ibidem, tezy 28 i 32.
} 
Zamierzano również wprowadzić pewne zróżnicowanie wymiaru składki zależnie od stopnia zagrożeń stwarzanych dla zdrowia i życia pracowników przez warunki pracy panujące w różnych zakładach pracy. Miałoby to przybrać formę składki dodatkowej, obciążającej zakłady „o gorszych warunkach higienicznych lub niebezpieczniejszych urządzeniach". Oznaczało to zamiar utrzymania pewnych elementów tzw. gry składki wypadkowej, która odgrywała dość znaczną rolę jako element akcji zapobiegawczej w przedwojennym systemie ubezpieczeń. Pozostawało natomiast sprawą otwartą pogodzenie tego zróżnicowania składek z postulowanym wprowadzeniem składki łącznej na wszystkie rodzaje ubezpieczenia społecznego (łącznie z ubezpieczeniem wypadkowym) ${ }^{29}$.

Ostatni element planowanej struktury ubezpieczenia społecznego stanowiły jego formy organizacyjne. W tym zakresie postulowano wyciągnięcie pełnych konsekwencji z realizowanych przed wojną tendencji scaleniowych, postulując objęcie całego kraju (łącznie z Górnym Śląskiem, na którym utrzymywały się przed wojną pewne odrębności) wraz z nowymi terytoriami jednolitym systemem organizacyjnym. Centralne ogniwo tego systemu miał stanowić nadal Zakład Ubezpieczeń Społecznych (i jego oddziały), a ogniwa terenowe - Ubezpieczalnie Społeczne, powołane do spełniania $\mathrm{w}$ zasadzie tych samych zadań co przed wojną, z zastrzeżeniem stopniowego wyodrębniania z zakresu ich działalności - lecznictwa ${ }^{30}$.

Ważniejsze jednak niż samo określenie schematu organizacyjnego ubezpieczenia społecznego było wypełnienie go żywą treścią, co wymagało zajęcia stanowiska wobec doniosłej społecznie sprawy samorządu ubezpieczeniowego. Samorząd ten miał w naszym kraju odległe tradycje sięgające 1920 r., został jednak w 1929 r. zlikwidowany i zastąpiony zarządem komisarycznym, co wywołało głęboki ferment $\mathrm{w}$ środowisku robotniczym i nie przestawało być przedmiotem krytyki, połączonej z żądaniem restytuowania tej instytucji.

Departament zajął zdecydowane stanowisko w tej sprawie, postulując nie tylko przywrócenie samorządu ubezpieczeniowego, lecz również rozszerzenie jego zadań. Stanowisko to wynikało z afirmowanej przez Departament idei solidarności ogółu ubezpieczonych, której urzeczywistnienie wymagało ich „najszerszego i najaktywniejszego współdziałania $[. ..] \mathrm{w}$ wykonywanej funkcji ubezpieczenia" ${ }^{\prime 31}$. Chodziło przy tym nie tylko o zapewnienie ubezpieczonym prawa współdecydowania w sprawach bezpośrednio ich interesujących, lecz także o stworzenie łączności pomiędzy instytucjami ubezpieczenia społecznego a ogółem ubezpieczonych i opartego na niej współdziałania w bieżącym wykonawstwie. $\mathrm{Na}$ ten ostatni aspekt funkcjonowania samorządu ubezpieczeniowego został położony szczególny nacisk w tezach Departamentu ${ }^{32}$.

\footnotetext{
${ }^{29}$ Ibidem, teza 29.

${ }^{30}$ Tezy dekretu porzadkujacego tymczasowo stan prawny w ubezpieczeniach spotecznych, teza $20,23$.

${ }^{31}$ US Wytyczne, teza 11.

${ }^{32}$ Tezy dotyczace ubezpieczeń, teza 9a.
} 
Do kompetencji samorządu ubezpieczeniowego miały należeć w koncepcji Departamentu sprawy: ustalania zasad organizacji lecznictwa, trybu wymiaru i poboru składek, ustalania okręgów i siedzib Ubezpieczalni Społecznych, ustalania zasad ubezpieczeń dodatkowych. Organy samorządu miały również opiniować projekty ustaw i rozporządzeń z zakresu ubezpieczeń społecznych. Dużą wagę przykładano też do udziału samorządu ubezpieczonych w sprawach bezpośredniego wykonawstwa: w kontroli poboru składek, w postępowaniu świadczeniowym $\mathrm{i}$ in..$^{33}$

Nie zostały bliżej określone formy organizacyjne samorządu ubezpieczeniowego. Przyjęto jednak, że powinni w nim zasiadać, poza przedstawicielami ubezpieczonych, także przedstawiciele pracodawców i samorządu terytorialnego. Osoby te miały być przy tym powoływane nie w drodze wyborów powszechnych, lecz desygnowane przez właściwe związki ${ }^{34}$.

Przedstawione koncepcje miały wprawdzie charakter tezowy i nie zostały opracowane w szczegółach, zarysowywały jednak wyraźnie postulowany kierunek rozwoju ubezpieczeń społecznych w przyszłej Polsce.

\section{Regulacja bezpośrednio powojenna}

Pełne urzeczywistnienie przedstawionych powyżej zamierzeń nie było możliwe bezpośrednio po wojnie. Należało jednak przystąpić niezwłocznie do przygotowywania tej reformy, a równocześnie wymagały uregulowania liczne kwestie natury prawnej i organizacyjnej, od których zależało prawidłowe funkcjonowanie instytucji ubezpieczeń społecznych na terenach wyzwalanych spod okupacji niemieckiej. Temu podwójnemu zadaniu miał służyć dekret o tymczasowym uporządkowaniu stanu prawnego w dziedzinie ubezpieczeń, na którego opracowaniu skupiła się główna uwaga Departamentu, jego tekst zachował się - jak już wspomniano - jedynie w części, o jego treści orientują jednak obszerne uzasadnienia dotyczące całości zawartych w nim przepisów.

Zgodnie z jego podwójnym zadaniem można w treści projektowanego dekretu odróżnić dwie warstwy: regulacje o charakterze doraźnym i przepisy zapoczątkowujące zmiany systemowe.

Pierwszemu z tych celów miało służyć generalne uchylenie wszystkich przepisów wydanych przez władze okupacyjne, ograniczających uprawnienia świadczeniowe i dyskryminujących ludność polską. Osobom, które doznały represji ze strony okupanta, miały być przyznawane świadczenia na specjalnych ulgowych warunkach (choćby nie mogły się wykazać przebyciem okresu wyczekiwania).

\footnotetext{
${ }^{33}$ Ibidem, teza 9b; Wytyczne projektu..., teza 14.

${ }^{34}$ Tezy dotyczace ubezpieczeń, 9a.
} 
Pozbawione uprawnień do świadczeń miały być natomiast osoby, które dopuściły się zdrady narodu polskiego i przyznały do narodowości niemieckiej ${ }^{35}$.

Zmierzając do uporządkowania sytuacji w dziedzinie uprawnień rentowych, postulowano utrzymanie $\mathrm{w}$ mocy decyzji świadczeniowych wydanych $\mathrm{w}$ okresie okupacji, z tym że zainteresowani mieliby prawo wnoszenia zażaleń (w ciągu 6 miesięcy), a instytucje ubezpieczeń społecznych mogłyby poddawać te decyzje rewizji $\mathrm{w}$ razie ich niezgodności z przepisami, co do stanu prawnego lub faktycznego ${ }^{36}$. Z tych samych względów postulowano uchylenie prawa do świadczeń niewypłaconych w czasie wojny (zaległych), proponując ewentualne zastąpienie ich przez jednorazowe wypłaty o charakterze odszkodowawczym ${ }^{37}$.

Licząc się ze szczególnymi problemami, jakie musiały powstawać w związ$\mathrm{ku} \mathrm{z}$ ustaleniem uprawnień świadczeniowych osób przechodzących na rentę bezpośrednio po wojnie, projektowano zastosowanie w tym zakresie daleko idących uproszczeń. Dotyczyły one w szczególności zaliczania okresów przebytych w ubezpieczeniu w czasie wojny. W celu zaoszczędzenia ogromnej pracy, jaką byłoby dokonywanie (odtwarzanie) wstecz ewidencji okresów zatrudnienia o różnym rodzaju i charakterze oraz mając na uwadze fakt, że wobec totalnego charakteru wojny przytłaczająca większość ubezpieczonych znajdowała się w tym czasie w sytuacji uzasadniającej zachowanie uprawnień ubezpieczeniowych, projektowano przyjęcie jako ogólnej zasady, że wszystkim osobom, które były ubezpieczone już przed wojną, zalicza się cały okres wojny na poczet ich uprawnień zarówno co do długości stażu, jak i jego wpływu na wymiar świadczeń3 ${ }^{38}$. Zaliczenie to nie mogło natomiast dotyczyć poziomu zarobków z czasu okupacji, wobec czego należało przewidzieć odpowiednie przeliczenia nawiązujące do nowych skal zarobkowych oraz zasad określania wymiaru rent.

Ta ostatnia sprawa mogła być, jak należało przewidywać, źródłem poważnych trudności ze względu na płynność stosunków społeczno-gospodarczych bezpośrednio po wojnie, zmienną wartość pieniądza oraz stopniową odbudowę wartości realnej świadczeń rentowych. Trudno byłoby postulować w tym zakresie ściślejszą regulację ustawową, narzucała się więc konieczność powierzenia tych ustaleń odpowiednim organom państwowym.

Wymagało to stosunkowo licznych delegacji ustawowych, których w ubezpieczeniu społecznym, co do zasady, należałoby unikać. W szczególnych warunkach powojennych wydawały się one jednak niezbędne ze względu na nieuniknioną elastyczność przejściowych unormowań, przystosowujących stopniowo formy działania ubezpieczenia i konstrukcje świadczeniowe do nowych warunków ${ }^{39}$.

\footnotetext{
${ }^{35}$ US Wytyczne, tezy 27, 31; Tezy dekretu ..., pkt 1 zd. 1, pkt 8, 9.

${ }^{36}$ Tezy dekretu..., teza 13; Dekret. Projekt, art. 8.

${ }^{37}$ Ibidem, art. 19; US Wytyczne, teza 30.

${ }^{38}$ Ibidem, art. 10; US Wytyczne, teza 25.

${ }^{39}$ US Wytyczne, teza 32.
} 
W zakresie organizacyjnym uznano za sprawę podstawową odbudowę dawnej struktury ubezpieczenia, obejmującej jednolicie cały kraj. Na czele instytucji ubezpieczenia społecznego powinni stanąć w okresie przejściowym komisarze (pełnomocnicy rządu) ze względu na „konieczność skoncentrowania całokształtu spraw $[\ldots] \mathrm{w}$ jednym ręku $\mathrm{w}$ okresie licznych procesów reorganizacji i odbudowy instytucji” oraz aby zapewnić „sprawne funkcjonowanie, szybką decyzję, panowanie nad sytuacją i jednolite postępowanie". Samorząd ubezpieczeniowy nie mógłby być ustanowiony od razu, do zadań pełnomocników rządu należałoby jednak przygotowanie jego wprowadzenia (co powinno nastąpić w ciągu roku). Przejściowo miały natomiast funkcjonować przy pełnomocnikach organy doradcze składające się z przedstawicieli czynnika społecznego ${ }^{40}$.

Ze względu na znaczny ubytek fachowej kadry w instytucjach ubezpieczenia społecznego postulowano z jednej strony - uproszczenie trybu postępowania i usprawnienie działalności tych instytucji, a z drugiej strony - pewne rygory, ograniczające swobodę rozwiązywania umów o pracę przez pracowników (miało to dotyczyć zwłaszcza osób zatrudnionych w aparacie ubezpieczenia chorobowego $)^{41}$. Licząc się z mnogością sporów w sprawach świadczeniowych, projektowano utworzenie przejściowo, do czasu powołania sądownictwa ubezpieczeń społecznych, jednolitego, prostego systemu odwoławczego ${ }^{42}$.

Dekret o tymczasowym uporządkowaniu stanu prawnego $\mathrm{w}$ dziedzinie ubezpieczeń społecznych miał jednak nie tylko uregulować sprawy bezpośrednio najpilniejsze, lecz również zapoczątkować przebudowę tej instytucji, zgodną z przedstawionymi poprzednio zamierzeniami. W związku z tym „odrzucona została myśl całkowitego powrotu do stosunków prawnych przedwojennych", postanowiono bowiem „,nie restytuować tych norm prawnych, które wojna zmieniła", jeżeli nie leżały one na linii postulowanej reformy ${ }^{43}$.

Chodziło tutaj w szczególności o zmiany, których nie można było uważać za ,elementy obce”, ponieważ doszły one do skutku w znacznej mierze jako rezultat inicjatywy czynników polskich i nawiązywały do ,przedwojennych wątków polskiej myśli ubezpieczeniowej" ${ }^{4}$. Do zmian tego rodzaju należało zniesienie ograniczeń czasowych w udzielaniu pomocy leczniczej z ubezpieczenia chorobowego, a także objęcie tą pomocą rencistów: inwalidów i starców, oraz rozciągnięcie jej na ogólnie stosowanych zasadach na pracowników „publicznych" (którzy przed wojną korzystali z odrębnych systemów lecznictwa). Zmiany te torowały drogę scaleniu organizacyjnemu pomocy leczniczej w stosunku do grup ludności, które przed wojną pozostawały poza ubezpieczeniem na wypa-

\footnotetext{
${ }^{40}$ Uzasadnienie dekretu o tymczasowym..., art. 46-49; Tezy dekretu..., pkt 24.

${ }^{41}$ Uzasadnienie dekretu o tymczasowym..., art. 50.

${ }^{42}$ US Wytyczne, 32 in fine; Uzasadnienie do dekretu o tymczasowym..., art. 27.

${ }^{43}$ Uzasadnienie dekretu (kartka); Uwagi ogólne, ust. 1.

${ }^{44}$ Ibidem, ust. 2.
} 
dek choroby. Zapoczątkowywały one tym samym upowszechnienie służby zdrowia, na razie jeszcze w ramach ubezpieczenia społecznego, ale z perspektywą jej wyodrębnienia w osobny system świadczeń.

Postulowano również wyciągnięcie konsekwencji ze zmian, jakie zaszły w czasie wojny w ubezpieczeniu emerytalnym. W okresie tym zatarły się dawno różnice w wymiarze świadczeń pomiędzy pracownikami umysłowymi a robotnikami, gdyż uprawnienia jednych i drugich zostały sprowadzone do jednolicie wymierzanych świadczeń, których realna wartość zresztą stale malała i ostatecznie spadła o wiele poniżej biologicznego minimum egzystencji. Po wojnie należało oczywiście dążyć do podniesienia ich poziomu tak, aby mogły stanowić realną podstawę utrzymania, jednakże trzeba było z góry liczyć się z tym, że będzie to mogło następować jedynie stopniowo, w ciągu dłuższego czasu. W tych warunkach jakiekolwiek różnicowanie ich wymiaru, zależnie od przynależności do takiej czy innej grupy społecznej, nie miałoby racji bytu. Przekreślało to jakikolwiek sens powrotu do dawnej dyferencjacji, oddzielającej systemy pracowników umysłowych i robotników, która już przed wojną budziła zasadnicze zastrzeżenia ze względów społecznych (nie mówiąc o tym, że opierała się na bardzo kruchych podstawach finansowych, gdyż stosunkowo wysokie świadczenia przyznane pracownikom umysłowym nie miały dostatecznego zabezpieczenia we wpływach ze składek).

Sam niedostatek środków wymuszał już pożądane społecznie ujednolicenie ubezpieczenia emerytalnego, jakkolwiek musiało to, co najmniej przejściowo, nastąpić za cenę ustalenia świadczeń na bardzo niskim poziomie ${ }^{45}$.W dalszej perspektywie przewidywano natomiast regulację, w której zasadniczą rolę miała odgrywać - jak już stwierdzono - tzw. kwota podstawowa renty, a wtórne znacznie miało przypadać kwocie wzrostu renty, różnicującej wymiar tego świadczenia, zależnie od poziomu zarobków i okresów przebytych w ubezpieczeniu.

$\mathrm{W}$ ten sposób scalenie systemu ubezpieczenia emerytalnego miało kojarzyć się z daleko idącym ujednoliceniem wymiaru świadczeń, w zasadzie na poziomie odpowiadającym minimalnym kosztom utrzymania, co pozostawało $\mathrm{w}$ zgodzie z rolą wyznaczaną powszechnemu systemowi ubezpieczenia. Poważniejsze zróżnicowanie świadczeń zależnie od poziomu zarobków miało, zgodnie z koncepcją Departamentu, następować poprzez systemy ubezpieczenia dodatkowego, o charakterze branżowym, zawodowym czy też zakładowym.

Dodać należy, że omówione powyżej scalenie systemu ubezpieczenia emerytalnego miało dotyczyć również funkcjonariuszy pozostających w służbie publicznej, którzy już w czasie wojny zostali pozbawieni odrębnych uprawnień i otrzymywali renty na tym samym poziomie co pozostali pracownicy. Tak więc $i \mathrm{w}$ tej dziedzinie zmiany, jakie dokonały się w czasie wojny, torowały drogę pożądanym rozwiązaniom na przyszłość.

${ }^{45}$ US Wytyczne, teza 19. Uzasadnienie dekretu (kartka), s. 5 (ust. 3). 
Utrwalenie zmian dokonanych w czasie wojny przewidywano również w stosunku do tzw. zaopatrzeń, tj. świadczeń wypłacanych (w razie braku innych środków utrzymania) osobom, które już w 1934 r. (a więc w czasie, gdy wchodziły w życie przepisy o ubezpieczeniu emerytalnym robotników) przekroczyły wiek uprawniający do renty z tytułu starości i nie mogły w związku z tym wykazać się żadnym okresem przebytym w ubezpieczeniu. Przepis ten dotyczył pierwotnie osób urodzonych nie później niż w roku 1873. W czasie wojny rozszerzono jego zastosowanie na dwa dalsze roczniki (1874 i 1875), co obecnie proponowano utrwalić $^{46}$. Sprawa ta nie miała jednak systemowego znaczenia, gdyż zaopatrzenia były formą świadczeń o charakterze przejściowym, co do których należało liczyć się, że w stosunkowo krótkim czasie stracą rację bytu.

W opracowaniach Departamentu znalazło się poza tym wiele propozycji szczegółowych, dotyczących np. zasad wymiaru różnych świadczeń i innych. Sprawy te jednak pomijamy, gdyż dotyczyły one kwestii o wtórnym znaczeniu, a ponadto, wobec niezachowania się pełnego tekstu projektowanego dekretu, trudno ocenić, czy propozycje te odpowiadały ukształtowanemu już stanowisku Departamentu, czy też były jeszcze przedmiotem wewnętrznych dyskusji.

\section{Inne problemy}

Zachowane dokumenty świadczą o tym, że w Departamencie były opracowywane również inne problemy, dotyczące ubezpieczeń społecznych w okresie okupacji i w latach powojennych. Należała do nich w szczególności próba oszacowania strat poniesionych przez instytucje ubezpieczeń społecznych, pod kątem przyszłych odszkodowań. Szkody wojenne, objęte tym szacunkiem, zostały zestawione w 4 pozycjach określających:

1) straty instytucji ubezpieczeń społecznych w majątku (zarówno w jego substancji przedwojennej, jak i w przyroście w czasie wojny);

2) wzrost wydatków związanych ze zwiększonym ryzykiem ubezpieczeniowym w czasie wojny (a więc w związku ze zwiększoną śmiertelnością i inwalidnością, obniżeniem się ogólnego poziomu zdrowotności i in.);

3) wzrost zobowiązań z tytułu przejęcia świadczeń i ekspektatyw obcych (co dotyczyło w szczególności świadczeń dla obywateli polskich z tytułu pracy w Rzeszy oraz świadczeń należnych repatriantom z innych krajów);

4) straty ubezpieczonych zarówno w należnych im świadczeniach, jak i ekspektatywach $^{47}$.

\footnotetext{
${ }^{46}$ Uzasadnienie do dekretu o tymczasowym..., s. 1, ust. 5; Uzasadnienie dekretu (kartka), s. 4, art. 14.

${ }^{47}$ Problemy odszkodowawcze $w$ ubezpieczeniach społecznych, s. 1 i n.; Działalność, straty i potrzeby ubezpieczeń społecznych, maszynopis, stron 8.
} 
Co do tej ostatniej pozycji przyjmowano, zgodnie z przedstawionym stanowiskiem, że nie będą one wyrównane przez instytucje ubezpieczeń społecznych; liczono się jednak z wypłatą jednorazowych odpraw z tego tytułu. Pomocniczy dokument do tego opracowania stanowiła obszerniejsza informacja, dotycząca działalności i strat instytucji ubezpieczeń społecznych w okresie wojny na różnych terytoriach objętych okupacją niemiecką oraz przewidywanych potrzeb powojennych, zwłaszcza w zakresie ubezpieczenia chorobowego.

Przedmiotem zainteresowania Departamentu była sprawa rozwoju uspołecznionego lecznictwa w dalszej perspektywie czasu, gdy należało oczekiwać, że wykroczy ono poza ramy ubezpieczenia chorobowego. Za cel ostateczny tej ewolucji uznawano „utworzenie powszechnej pomocy lekarskiej na podobieństwo powszechnego nauczania", a w pierwszej fazie proponowano udostępnienie jej ogółowi ludności w nagłych wypadkach, w położnictwie i w chorobach zakaźnych ${ }^{48}$. Równocześnie należało rozbudować opiekę nad matką i dzieckiem.

Bliższą uwagę skupiała w związku z tym na sobie sprawa wyrównania upośledzenia wsi w zakresie opieki zdrowotnej oraz potrzeb ubezpieczeniowych ludności wiejskiej, i to zarówno w zakresie ubezpieczeń społecznych, jak i indywidualnych.

\section{Uwagi końcowe}

Opracowania koncepcyjne Departamentu w zakresie ubezpieczeń nie przybrały, jak już stwierdzono, wykończonej formy. Postulowane kierunki zmian zarysowały się w nich jednak wyraźnie zarówno w kwestiach dotyczących lat bezpośrednio powojennych, jak i dalszej perspektywy czasu, przy czym jedne i drugie były połączone wspólną myślą i zmierzały do głębokiej przebudowy ubezpieczeń społecznych, zmieniającej zasadniczo obraz tej instytucji w porównaniu ze stanem $z$ lat przedwojennych.

Ubezpieczenia społeczne miały uzyskać, w porównaniu ze stanem z lat trzydziestych, znacznie szerszy zakres osobowy, miały cechować się większą jednolitością konstrukcji prawno-organizacyjnych i świadczeniowych, przekreślającą dawne linie podziału, miały być oparte na zdrowych, przejrzystych i realistycznie pomyślanych zasadach finansowych oraz miały być zarządzane przy poważnym udziale czynnika społecznego. Koncepcje te uzupełniała perspektywa stopniowej rozbudowy wyodrębniającej się z ubezpieczenia społecznego służby zdrowia, która miała objąć szerokim zakresem bezpłatnych świadczeń całą ludność. Na uwagę zasługiwała również projektowana konstrukcja pieniężnych świadczeń

\footnotetext{
${ }^{48}$ Notatka bez tytułu dotycząca opieki lekarskiej i akcji zapobiegawczej („Człowiek, jego liczebność...) II, 2.
} 
długoterminowych (rent), oparta na rozróżnieniu powszechnych świadczeń zapewniających godziwe minimum egzystencji oraz świadczeń uzupełniających, wymierzanych w relacji do poprzednio pobieranych zarobków, na gruncie ubezpieczenia dodatkowego - w zamian za dodatkową składkę.

Koncepcje powyższe nawiązywały po części do zaznaczających się już przed wojną trendów rozwojowych (zwłaszcza w tym, co dotyczyło struktury organizacyjnej ubezpieczenia społecznego), jednakże w przeważającej mierze wyrażały idee nowe, zmierzające do przezwyciężenia tego, co w przedwojennym systemie było niesprawiedliwe (linie podziału) bądź pozbawione żywej społecznej treści (brak samorządu), bądź wreszcie nazbyt ograniczające (zakres dostępności uspołecznionego lecznictwa). 



\section{Opieka społeczna}

\section{Uwagi ogólne}

Znaczenie opieki społecznej w pracach koncepcyjnych Departamentu mierzyło się przede wszystkim przewidywanym nasileniem potrzeb, z jakich wystąpieniem należało się liczyć w okresie bezpośrednio powojennym i przez dłuższy czas jeszcze po zakończeniu wojny. Pewną orientację w narastaniu tych potrzeb dawała prowadzona przez Departament akcja opieki czynnej, jakkolwiek obejmowała ona kręgi ludności najbardziej represjonowanej przez okupanta. Nie bez znaczenia było też powiązanie wielu ogniw Delegatury, a w szczególności Departamentu Pracy, z Radą Główną Opiekuńczą, która dawała oparcie różnym organizacyjnym poczynaniom oraz rozwijała szeroką akcję opieki i pomocy społecznej w stosunku do różnych warstw społeczeństwa polskiego.

Realnie należało liczyć się z tym, że skutki wojny i okupacji długo jeszcze będą odbijały się na warunkach życia ludności, co będzie wymagało wielkiej mobilizacji sił i środków w celu zaspokojenia elementarnych potrzeb. Wydawało się zatem rzeczą ważną obmyślenie już w czasie wojny metod działania, które mogłyby przyczynić się do zgromadzenia tych środków oraz zapewnić ich optymalne spożytkowanie. Sprawy te należało przy tym rozważać w szerszym horyzoncie, nie tylko szczególnej sytuacji chwil przełomowych i lat bezpośrednio powojennych, lecz również pod kątem nadania właściwego kierunku rozwojowi opieki społecznej na przyszłość.

Ten ostatni wątek wiązał się ściśle z całokształtem prac koncepcyjnych Departamentu. Problematyka opieki społecznej kojarzyła się przede wszystkim z zagadnieniami przyszłego rozwoju ubezpieczeń społecznych, ze względu na pokrewny charakter potrzeb zaspokajanych przez obie te instytucje, obejmowane już w tym czasie na Zachodzie szerszymi planami zabezpieczenia społecznego. Sprawy opieki społecznej były jednak rozpatrywane przez Departament w kontekście dalej sięgających powiązań. Opieka społeczna stanowiła bowiem w koncepcji Departamentu organiczną część polityki społecznej, co znajdowało wyraz we wspólnocie celów, do których zaliczano w całym tym rozległym obszarze 
kształtowanie stosunków wzajemnych i postaw obywateli oraz warunków określających ich poziom życia i stan zdrowia ${ }^{1}$. Opieka społeczna pojmowana była przy tym jako dział polityki społecznej sięgający do „podstaw egzystencji obywateli” oraz mający bezpośrednią „styczność z ich życiem”2 i oddziaływający na „sferę najbliższą życia rodzin i jednostek”. Ze względu na to mogło następować w ramach opieki organizacyjne łączenie „na stopniu wykonawczym” działań o różnym charakterze, służących najlepiej zaspokajaniu ich potrzeb ${ }^{4}$. Duży nacisk położony został przy tym na przepojenie wszelkiej działalności w zakresie opieki społecznej ,pierwiastkami wychowawczymi”, co powinno sprzyjać „psychicznej przebudowie" społeczeństwa w płaszczyźnie szeroko pojętej akcji profilaktycznej5. Szczególną uwagę należało zwrócić w opiece społecznej (podobnie jak w całym zakresie polityki społecznej) na potrzeby ludności wiejskiej ${ }^{6}$.

W dziale tym, podobnie jak w innych zakresach prac Departamentu, należy rozróżnić prace koncepcyjne, sięgające dalej w przyszłość oraz służące bezpośrednio zaspokajaniu potrzeb okresu ,przejściowego”. W danym przypadku podział ten miał w pewnym stopniu również charakter rzeczowy, gdyż prace przyszłościowe dotyczyły głównie ulepszenia podstaw prawno-organizacyjnych opieki społecznej, sprawowanej przez organy publiczne, a prace mające na uwadze potrzeby lat bezpośrednio powojennych skupiły się wokół działalności o charakterze szeroko pojętej społecznej samopomocy, która nawiązywała do form akcji opiekuńczej, rozwiniętej w czasie wojny w ramach Rady Głównej Opiekuńczej. W rozdziale niniejszym zajmiemy się kolejno każdym z tych zakresów.

\section{Opieka o charakterze publicznym}

Prace koncepcyjne Departamentu, dotyczące tego podstawowego działu opieki, znalazły wyraz w dwóch dokumentach, z których pierwszy nosił tytuł Tezy wstepne o pomocy i opiece (46 tez wraz z uzasadnieniem), a drugi, bardziej wykończony w formie - Próba ustawowego ujęcia pomocy i opieki społecznej w oparciu o ustawe o opiece społecznej z dnia 16 VIII 19237. Z samego charakteru tych dokumentów wynika, że nie wyszły one poza ogólne ujęcie koncepcji

${ }^{1}$ Tezy wstepne o pomocy $i$ opiece, tezy 1-2 oraz uzasadnienie do tych tez.

2 Ibidem, teza 3.

${ }^{3}$ Ibidem, teza 7.

${ }^{4}$ Ibidem, teza 7.

${ }^{5}$ Próba ustawowego ujęcia pomocy i opieki społecznej w oparciu o ustawe o opiece społecznej $z$ dnia 16 VIII 1923, art. 3.

${ }^{6}$ Ibidem, art. 4.

${ }^{7}$ Poza tym opracowane zostały Tezy o opiece nad niewidomymi, która miałaby być powierzona „,instytucjom społecznym działającym w porozumieniu z samorządem terytorialnym i lokalnymi ośrodkami opieki i zdrowia” (teza 1). 
programowych, które choć zostały bardziej ukonkretnione w drugim dokumencie, to stanowiły nadal jedynie próbę sformułowania treści projektowanych przepisów o charakterze raczej tezowym.

$\mathrm{Z}$ tytułu nadanego drugiemu $\mathrm{z}$ wymienionych wyżej dokumentów wynikało ponadto, że zamierzeniem Departamentu nie było przygotowanie nowego aktu regulującego podstawy prawne opieki społecznej, lecz jedynie ulepszenie obowiązującej ustawy z $1923 \mathrm{r}$. Zawierała się w tym pozytywna ocena podstawowych rozwiązań prawnych tamtej ustawy, której istotny walor polegał na przesunięciu ciężaru obowiązków w zakresie opieki społecznej z instytucji dobroczynnych na organy publiczne i uwolnieniu jej tym samym od piętna akcji charytatywnej. Ten charakter opieki społecznej zamierzano w pełni utrzymać, a równocześnie uczynić ją pełniejszą i bardziej efektywną, co wymagało pewnych zmian prawnoorganizacyjnych, a także co do podstaw finansowych działalności opiekuńczej. Główny punkt zainteresowania stanowi tym samym zdanie sobie sprawy, na czym miałyby, według Departamentu, polegać te zmiany.

W tym celu należy przede wszystkim sięgnąć do sformułowań określających samą definicję opieki społecznej. Sformułowanie zawarte w Próbie ustawowego ujęcia wykazuje w istocie podobieństwo do definicji zawartej w dawnej ustawie ${ }^{8}$. W obu dokumentach określa się bowiem opiekę społeczną jako zaspokajanie niezbędnych potrzeb życiowych osób, które trwale lub chwilowo własnymi środkami lub własną pracą uczynić tego nie mogą. W obu dokumentach zaliczono też do zadań opieki społecznej zapobieganie wytwarzaniu się takiego stanu (czemu zgodnie z opracowaniem Departamentu miała służyć „działalność instrukcyjnowychowawcza i pomoc uprzedzająca"). Zgodnie z treścią tego dokumentu zaspokajanie wyżej wymienionych potrzeb miało jednak następować ze środków publicznych i społecznych, a nie tylko publicznych, jak to stwierdzała dawna ustawa. Wyrażało się w tym dążenie do nadania działalności opiekuńczej szerszego zasięgu i włączenia do niej szerszych kręgów społeczeństwa i na tej drodze pomnożenia jej środków; do wątku tego nawiążemy w toku dalszych uwag.

Ponadto, w ujęciu Departamentu opieka społeczna miała zaspokajać potrzeby nie tylko materialne, lecz także moralne, i to mające źródło zarówno w upośledzeniu przez los, jak i w wadach ustroju społeczno-gospodarczego oraz we własnym postępowaniu potrzebujących pomocy; osobno wymieniono poza tym udzielanie pomocy w spełnianiu szczególnie ważnych funkcji społecznych, do których zaliczono przede wszystkim macierzyństwo.

Kategoryzacja ta miała istotne znaczenie z punktu widzenia charakteru i form sprawowanej opieki, do czego jeszcze powrócimy. Mniej istotne znaczenie miało natomiast stwierdzenie $\mathrm{w}$ dokumencie departamentalnym, że zaspokajanie potrzeb powinno następować „do stosownego poziomu życia”, trudno było bowiem

${ }^{8}$ Próba ustawowego ujęcia..., art. 5; Ustawa z dnia 16 sierpnia1923 r. o opiece społecznej (Dz. U. 1923, nr 92, poz. 726), art. 1. 
zakładać, aby opieka społeczna mogła wykroczyć poza zakres niezbędnych potrzeb i usuwanie elementarnych braków. Departament postulował natomiast aktywną rolę instytucji opieki społecznej w wychodzeniu naprzeciw potrzebom występującym $\mathrm{w}$ danym środowisku, choćby nie zostały one zgłoszone. Pomoc i opieka miały być bowiem udzielane - zgodnie z sugestią Departamentu - „nie tylko tym, którzy się o nią słusznie ubiegają, ale i tym, którzy pozostawieni sami sobie, trwaliby w stanie przynoszącym szkodę im samym i społeczeństwu”."

Do zakresu pomocy i opieki społecznej włączona została na pierwszym miejscu pomoc rodzinie i ochrona macierzyństwa, a w dalszej kolejności m.in. pomoc dla repatriantów i reemigrantów, ze względu na szczególne potrzeby okresu bezpośrednio powojennego. Na uwagę zasługuje włączenie do zadań opieki społecznej działań, służących „usunięciu opóźnień w rozwoju środowisk” oraz mających na celu „zmianę warunków, które wywołują potrzebę występowania (o pomoc)”, a to we współdziałaniu z różnymi podmiotami pomocy społecznej. Działania te miałyby w szczególności polegać na udzielaniu pomocy w usamodzielnieniu gospodarczym, na popieraniu taniego budownictwa mieszkań, udostępnianiu ogródków działkowych oraz podejmowaniu akcji służących poprawie stanu zdrowia, a „niezwiązanych ze zwykłym zakresem pomocy zdrowotnej"10 $\mathrm{i}$ in. Szerzej niż w ustawie z 1923 r. zostały też rozwinięte środki zaspokajania potrzeb, do których zaliczono m.in. „wykrywanie przypadków maltretowania, złego wychowania lub uchylania się od obowiązku utrzymania rodziny i przekazywanie ich sądom specjalnym""1.

Do źródeł finansowania pomocy i opieki społecznej zaliczono, poza środkami budżetowymi organów samorządu terytorialnego i czerpanymi z budżetu państwa oraz dochodami z funduszów o specjalnym przeznaczeniu, także daninę powszechną mającą obciążać, skromną zresztą kwotą, wszystkich obywateli od ukończonego 21. roku życia ${ }^{12}$. Okoliczność ta znalazła odbicie w omówionej powyżej definicji opieki społecznej w postaci wzmianki o finansowaniu jej nie tylko z funduszów publicznych, lecz także społecznych. Środki płynące ze wspomnianej wyżej daniny miały pozostawać w bezpośredniej dyspozycji Ministra.

Głównym podmiotem obowiązków miały być nadal gminy - w stosunku do osób zamieszkujących (od roku), a w wyjątkowych okolicznościach także przejściowo przebywających na ich terenie, przy czym projektowano takie uregulowanie tego zakresu spraw, aby wykluczyć odmowę udzielenia pomocy w obliczu pilnych potrzeb oraz aby zapobiec odsyłaniu podopiecznych z jednej gminy do drugiej.

Niezależnie od tego stwierdzono jednak w omawianym dokumencie, że obowiązki w zakresie opieki ciążą „na całym społeczeństwie, działającym przez

\footnotetext{
${ }^{9}$ Próba ustawowego ujęcia..., art. 5 zd. 2.

${ }^{10}$ Ibidem, art. $6 \mathrm{i}$.

${ }^{11}$ Ibidem, art. $7 \mathrm{~g}$.

${ }^{12}$ Ibidem, art. 8e.
} 
jednostki i grupy społeczne"13, w czym zawierała się myśl o potrzebie spożytkowania $w$ tej dziedzinie inicjatyw jednostkowych i zbiorowych, przybierających różne formy (m.in. tworzenia „dobrowolnych związków, mających na celu lepsze organizowanie i doskonalenie świadczeń"14, czy też dobrowolnych zgłoszeń udziału w bezpośrednim wykonawstwie, z których wynikać miał następnie obowiązek prowadzenia zadeklarowanych prac). „Kto w tych warunkach podejmuje się pracy - czytamy w innym dokumencie - prowadzi ją w imieniu społeczeństwa. Postulatem jest, by nie była ona zaspokajaniem przejściowych nastawien, lecz dobrowolnym spełnianiem funkcji publicznych" ${ }^{15}$. Z dalszych wyjaśnień wynika, że chodziło tu o uogólnienie zasady przyjętej w stosunku do tzw. opiekunów społecznych, działających w wyniku dobrowolnych zgłoszeń, ale obciążonych zadaniami, które wymagały wypełniania ich w sposób ciągły.

Położenie tak wielkiego nacisku na rolę czynnika obywatelskiego w opiece społecznej jest cechą znamienną omawianych projektów. Znaczenie tego czynnika wzrastało tym bardziej, jeśli zważyć, że główny punkt ciężkości miał spoczywać na formach tzw. opieki otwartej, w której praca społeczna ma z natury rzeczy znacznie większą rolę do odegrania niż w „zamkniętych” zakładach opiekuńczych, wymagających większej fachowości. Praca społeczna musiała być oczywiście kontrolowana i koordynowana z całokształtem działań opiekuńczych. Zadanie to miało należeć do organów samorządu terytorialnego; zastrzegano się natomiast przeciwko tworzeniu ,jednej instytucji o charakterze półpublicznym, nadrzędnie kierującej całą działalnością »dobrowolną społeczeństwa w sferze pomocy i opieki”. Oznaczało to odżegnanie się od takich pseudodobrowolnych rozwiązań, które przypominały wzory hitlerowskie ${ }^{16}$.

Pewien udział w działalności opiekuńczej przewidywano również dla zakładów pracy (zwłaszcza wielkich). Miał on polegać głównie na świadczeniach organizacyjnych i materialnych na rzecz miejscowych ośrodków pomocy i opieki społecznej (lokale, opłata personelu), zwłaszcza na rzecz tych dziedzin ich działalności, które byłyby obciążone następstwami życia i pracy w środowisku przemysłowym oraz w przypadku, gdy działalność ta przynosiłaby pośrednio korzyść tym zakładom pracy. Przewidywano również możliwość podejmowania przez zakłady pracy dalej idących inicjatyw w zakresie prowadzenia pomocy i opieki w pewnych formach, $\mathrm{z}$ tym że odmawiano im w tym przypadku praw przeprowadzania tzw. wywiadów środowiskowych w miejscach zamieszkania pracowników (uznając, że byłoby to niemoralne ze względu na ich zależność służbową od pracodawcy $)^{17}$.

\footnotetext{
${ }^{13}$ Ibidem, art. 10a.

${ }^{14}$ Ibidem, art. 10c.

${ }^{15}$ Uzasadnienie tez wstęnych o pomocy i opiece społecznej (do tezy 17).

${ }^{16} \mathrm{Ibidem}$, do tezy 19.

${ }^{17}$ Tezy wstepne..., teza 21.
} 
Pomocniczą rolę w zakresie opieki społecznej miał spełniać samorząd społeczno-gospodarczy (izby pracy, izby wolnych zawodów i gospodarcze) w formie współdziałania w usprawnieniu działalności świadczeniowej, a także organizowania własnych systemów zaopatrzeń i zakładów zamkniętych na potrzeby określonych kręgów ludności ${ }^{18}$.

Ogólne kierownictwo, koordynacja i nadzór nad całokształtem działalności opiekuńczej miały być ześrodkowane w resorcie państwowym (dla którego proponowano nazwę: Ministerstwo Spraw Społecznych) oraz w wojewódzkich wydziałach i powiatowych referatach pomocy i opieki społecznej. Bezpośrednie wykonawstwo w terenie miało natomiast należeć do gminnych ośrodków, w których agendy pomocy i opieki społecznej byłyby zespolone $\mathrm{z}$ agendami służby zdrowia ${ }^{19}$.

Istotne znaczenie miało wspomniane wyżej rozróżnienie trzech rodzajów działalności opiekuńczej, określonych jako: (1) opieka losowa, (2) opieka ustrojowa i (3) pomoc ${ }^{20}$. Pierwsza z nich miała dotyczyć osób dotkniętych przez wydarzenia losowe, pociągające za sobą skutki trwałe w zakresie upośledzenia możności zaspokojenia niezbędnych potrzeb. Chodziło tu o potrzeby podobne w swym charakterze do pokrywanych przez ubezpieczenia społeczne, pozostające jednak poza zakresem ich działalności świadczeniowej. Główną rolę miała tu spełniać opieka w formach zamkniętych, a więc umieszczanie w domach dla starców, dla inwalidów, kalek, dla sierot i in., w powiązaniu z akcją przeszkalania osób częściowo zdolnych do pracy, umieszczania dzieci w rodzinach zastępczych i in. Opieka ustrojowa miała obejmować osoby znajdujące się w stanie niedostatku z przyczyn związanych z ustrojem społecznym i postępowaniem samych poszkodowanych. I wreszcie pomoc miała dotyczyć osób spełniających funkcje szczególnie ważne ze społecznego punktu widzenia.

Te dwie ostatnie dziedziny, a szczególnie pomoc, miały skupiać na sobie główną uwagę ośrodków pomocy i opieki społecznej, przy czym za najważniejszą uznano „pomoc w macierzyństwie” od poczęcia dziecka do ukończenia przez nie drugiego roku życia ${ }^{21}$. Opieka ustrojowa miała działać subsydiarnie w stosunku do pomocy, tj. skupiać uwagę głównie na rodzinach, dążąc równocześnie do przekształcenia czynników działających środowiskowo i zmierzając w ten sposób do samounicestwienia się $e^{22}$. Oba te zakresy działania społeczno-opiekuńczego miały rozwijać się przede wszystkim w formach otwartych. Ze względu na przedstawione powyżej rozróżnienia terminologiczne, uznano za właściwe posługiwanie się w stosunku do całej instytucji nazwą ,pomoc i opieka społeczna” (dotyczyło

\footnotetext{
${ }^{18}$ Próba ustawowego ujęcia..., art. 26.

${ }^{19}$ Ibidem, art. 18 i 19.

${ }^{20}$ Tezy wstepne..., teza 5 i Uzasadnienie tez..., teza 5.

${ }^{21}$ Próba ustawowego ujęcia..., art. 21.

${ }^{22}$ Tezy wstęne..., teza 10.
} 
to m.in. także tytułu projektowanej ustawy oraz nazwy organów państwowych i samorządowych działających w tym zakresie).

W całości opracowania widoczna jest tendencja ściślejszego oznaczenia kręgu osób mających prawo do pomocy i opieki społecznej. Nie określono jednak bliżej charakteru tych uprawnień oraz dróg ich dochodzenia. Zainteresowanym miała przysługiwać w tej dziedzinie skarga na decyzje samorządowych organów wykonawczych, rozpatrywana w porządku administracyjno-prawnym, przez właściwe organa nadzorcze ${ }^{23}$.

Przewidziano natomiast utworzenie w ramach pomocy i opieki społecznej sądownictwa obywatelskiego, które miało dysponować sankcjami o charakterze wychowawczym w stosunku do osób, które „przez niechęć współdziałania uniemożliwiają swe dojście do samodzielnej egzystencji materialnej”; sankcją tą miało być stosowanie pracy przymusowej. Sądownictwu temu miało przysługiwać prawo występowania z wnioskami o ściganie karne ${ }^{24}$.

W okresie przejściowym przewidywano potrzebę utworzenia instytucji specjalnej, powołanej do udzielania pomocy repatriantom i emigrantom, a także wykonywania innych szczególnych zadań.

\section{Samopomoc społeczna}

Instytucją powołaną do spełnienia tych szczególnych zadań miał być Polski Komitet Samopomocy Społecznej, którego utworzenie planowano bezpośrednio po wojnie „w celu zorganizowania społeczeństwa w służbie dobrowolnej pomocy w łagodzeniu skutków działań wojennych i okupacji”'25. Rola komitetu miała polegać w szczególności na organizowaniu różnych form opieki nad ludnością dotkniętą skutkami wojny i okupacji, zwłaszcza nad dziećmi i młodzieżą, na tworzeniu, utrzymywaniu i wspieraniu różnych zakładów i urząazeń doraźnej i przejściowej opieki, takich jak: obozy i kwatery przejściowe, punkty zbiorcze i rozdzielcze, schroniska, domy noclegowe, domy chorych i in., na wykonywaniu opieki nad imigrantami i repatriantami łącznie z pomocą w osiedlaniu się i gospodarczym usamodzielnianiu, na zorganizowaniu służby informacyjnej i prowadzeniu kartoteki osób zaginionych. Komitet miał współdziałać z PCK i zagranicznymi placówkami opieki nad obywatelami polskimi w zakresie niesienia pomocy jeńcom, więźniom i innym osobom powracającym do kraju.

Komitetowi miał być przyznany charakter stowarzyszenia wyższej użyteczności. Przewidywano przejęcie przezeń majątku Rady Głównej Opiekuńczej, jak również majątku polskich stowarzyszeń i fundacji o celach opiekuńczych, które

\footnotetext{
${ }^{23}$ Próba ustawowego ujęcia..., art. 28.

${ }^{24}$ Ibidem, art. 25.

${ }^{25}$ Rozporządzenie o PKSS (projekt), art. 1 ust. 1.
} 
podczas okupacji pozostawały w administracji niemieckiej oraz majątku pozostawionego przez niemieckie instytucje o celach opiekuńczych. Wyłącznym prawem Komitetu miało być organizowanie zbiórek publicznych na cele opiekuńcze oraz dysponowanie darami przekazanymi z zagranicy na cele opieki społecznej. Środki finansowe Komitetu miały płynąć z dotacji, ofiar, darowizn, zbiórek publicznych i in. Jego rolą miało być organizowanie współpracy różnych instytucji działających w zakresie opieki społecznej: samorządu terytorialnego, stowarzyszeń i innych instytucji mających osobowość prawa publicznego i prywatnego.

Naczelnym organem Komitetu miało być prezydium 12-osobowe, składające się w 1/3 z osób mianowanych przez Ministra Pracy, a w 2/3 z osób delegowanych przez organy samorządu terytorialnego, gospodarczego i zawodowego oraz instytucje społeczne o znaczeniu ogólnopaństwowym. Organem opiniodawczym i doradczym Prezydium miała być Rada, składająca się z osób delegowanych przez wymienione wyżej instytucje, a także przez osoby prawne będące członkami Komitetu. Placówkami terenowymi Komitetu miały być wojewódzkie, powiatowe i gminne komitety samopomocy społecznej.

Bliższe postanowienia we wszystkich powyższych sprawach zawierał projekt rozporządzenia Rady Ministrów o Polskim Komitecie Samopomocy Społecznej oraz projekt rozporządzenia Ministra Pracy nadającego Komitetowi statut (którego tekst stanowił załącznik do tego aktu).

Nazwa Komitetu nawiązywała do instytucji powołanej przez władze polskie we wrześniu 1939 r. na terenie Warszawy (Stołeczny Komitet Samopomocy Społecznej) i istniejącej przez niecały rok pod okupacją (do czasu wcielenia jej do Rady Głównej Opiekuńczej). Charakterystyczną cechą projektowanej regulacji było ześrodkowanie działalności Komitetu na szczególnych zadaniach okresu bezpośrednio powojennego oraz powierzenie mu w tym czasie roli koordynacyjnej w stosunku do innych instytucji działających w zakresie pomocy i opieki społecznej. Pozostawała kwestią otwartą rola, a nawet sam byt Komitetu po spełnieniu owych szczególnych, przejściowych zadań oraz określenie czasu, w ciągu którego miał on działać. Treść projektowanych przepisów nie daje żadnej wskazówki w tych sprawach.

\section{Uwagi końcowe}

Prace koncepcyjne Departamentu w zakresie opieki społecznej przybrały jedynie w stosunku do okresu bezpośrednio powojennego bardziej ukonkretnione formy, co wyraziło się przygotowaniem projektu rozporządzeniu kreującego Polski Komitet Samopomocy Społecznej oraz jego statutu. W pozostałym zakresie opracowania przygotowane przez Departament nakreśliły jedynie ogólne koncepcje programowe. 
Z całości projektów przygotowanych przez Departament przebija tendencja szerokiej rozbudowy działalności społeczno-opiekuńczej, dążenie do wszechstronnego ujęcia potrzeb rodziny i jednostek, do zróżnicowania charakteru tej działalności zależnie od rodzaju potrzeb oraz ich podłoża oraz do preferowania działań, które mogłyby restytuować osoby podopieczne do pozycji samodzielnej. Na uwagę zasługuje również $\mathrm{w}$ tych opracowaniach tendencja przyciągnięcia do udziału w działalności opiekuńczej szerokich kręgów społeczeństwa, i to zarówno w okresie bezpośrednio powojennym, jak i w późniejszym czasie. 



\section{Zdrowie publiczne}

O sprawach ochrony zdrowia była już mowa w rozdziale dotyczącym ubezpieczeń społecznych. Lecznictwo ubezpieczeniowe miało bowiem w koncepcji Departamentu utorować drogę powstaniu powszechnej służby zdrowia, obejmującej całą ludność kraju oraz stać się jej częścią składową, a w znacznej mierze również podstawą organizacyjną. Ostatecznym celem tej ewolucji było „utworzenie powszechnej pomocy lekarskiej na podobieństwo powszechnego nauczania ${ }^{1}$, co wymagać musiało oczywiście dłuższych prac przygotowawczych, do których należało jednak, według Departamentu, przystąpić bezpośrednio po wojnie.

Ogólne kierunki tych prac oraz postulowanych zmian prawno-organizacyjnych zostały zarysowane $\mathrm{w}$ trzech dokumentach, mających charakter tez programowych ${ }^{2}$. Dają one dobre pojęcie o podstawowych koncepcjach Departamentu w tej dziedzinie. Zabrakło natomiast bardziej szczegółowego ich rozpracowania w postaci konkretnych projektów ustawodawczych, na co wpłynęło późniejsze podjęcie tych prac niż w innych zakresach przedmiotowych, którym poświęcone zostały poprzednie rozdziały. W tym stanie rzeczy musimy ograniczyć się do przedstawienia w kilku punktach najważniejszych myśli programowych, jakie znalazły wyraz w opracowaniach Departamentu, dotyczących ochrony zdrowia.

Podstawowe znaczenie miała idea ześrodkowania ,wszystkich agend prowadzących działalność na polu zagadnień zdrowotnych i ludnościowych" w jednym organie, a mianowicie w Państwowej Służbie Zdrowia, która miała ponosić za ten zakres spraw wyłączną odpowiedzialność ${ }^{3}$ Temu naczelnemu organowi miały podlegać wszystkie szpitale, sanatoria, lecznice, ośrodki zdrowia i gabinety lekarskie, a także pracownie chemiczne, bakteriologiczne, zakłady rentgenologiczne i apteki. Wszystkie te instytucje miały być ,prowadzone tylko przez służ-

\footnotetext{
${ }^{1}$ Opracowanie bez tytułu, zaczynające się od słów „Człowiek, jego liczebność, stan fizyczny i umysłowy...", pkt II, 2.

${ }^{2}$ Ibidem oraz dwa inne pt. Publiczna slużba zdrowia i Projekty polityki zdrowotnej zbliżone do siebie treściowo.

${ }^{3}$ Publiczna stużba..., p. 2.
} 
bę zdrowia, w jej imieniu, lub za jej zgodą" oraz tworzyć jednolitą organizację, niedopuszczającą do dublowania zadań4.

Podkreślić przy tym należy, że w państwowej służbie zdrowia miał się skupiać całokształt działalności, dotyczącej nie tylko wszelkich form i zakresów lecznictwa, lecz także profilaktyki (a więc nadzór nad higieną otoczenia, kontrola punktów spożywczych, nadzór nad warunkami pracy, zwalczanie chorób zakaźnych, higiena szkół, organizowanie wychowania fizycznego, szeroko zakrojona akacja uświadamiająca). Do państwowej służby zdrowia miało również należeć prowadzenie polityki ludnościowej, której cele określone zostały jako dążenie do „wzmożenia rozrodczości elementów najbardziej wartościowych i ograniczenie rozrodu grup społecznie ujemnych"s. Nie wskazano przy tym bliżej środków mających służyć temu celowi. Sformułowania zawarte w tym dokumencie pozwalają jednak wnosić, że główny akcent miał padać na akcję uświadamiającą, prowadzenie poradni przedślubnych, zwracanie uwagi na warunki ekonomiczne bytu ludności, organizowanie badań naukowych w dziedzinie eugeniki i in. W tym kontekście należy umiejscowić wzmiankę o oddziaływaniu za pomocą prawodawstwa, które miałoby spełniać rolę pomocniczą.

Następna ważna kwestia to zaplanowanie podstawowej sieci terenowej placówek służby zdrowia. Sieć ta miała mieć oparcie w jednostkach administracyjnych, jakie stanowiły dawne powiaty. Każdy powiat miał posiadać „samowystarczalną organizację terenową", w której naczelne miejsce zajmowałby szpital powiatowy „tak wyposażony pod względem urządzeń i personelu, żeby był w stanie sprostać wszystkim potrzebom ludności w dziedzinie ochrony zdrowia" na tym terenie ${ }^{6}$. Następne ogniwo miały stanowić ośrodki zdrowia „korzystające z pomocy szpitala i działające pod jego kierunkiem”, a przy tym „tak rozmieszczone na terenie powiatu, żeby było łatwo dostępne dla każdego obywatele szukającego pomocy"7. Każdy ośrodek zdrowia miał obejmować zakresem swego działania pewien obszar (gminę lub parę gmin). I wreszcie gabinety lekarskie miały być ,jakby dalszym ciągiem ośrodków zdrowia", uzupełniającym ich działalność ${ }^{8}$. Nie określono przy tym bliżej zasad organizowania i rozmieszczania tych gabinetów. Z kontekstu należy jednak wnosić, że chodziło tu o upowszechnienie instytucji tzw. lekarzy domowych, którzy stanowili przed wojną podstawową formę organizacji lecznictwa ubezpieczeniowego w centralnej Polsce.

Zastrzeżono odrębną organizację pomocy leczniczej i profilaktyki w sprawach „wymagających szerszych podstaw finansowych i kwalifikacji trudnych do uzyskania na terenie powiatu”, takich jak np. walka z gruźlicą czy chorobami

\footnotetext{
${ }^{4}$ Ibidem, p. 6.

${ }^{5}$ Ibidem, p. 3c, b.

${ }^{6}$ Projekty polityki..., p. 5 zd. 1.

${ }^{7}$ Ibidem, p. 5 zd. 2.

${ }^{8}$ Ibidem, p. 5 zd. 3.
} 
umysłowymi; przewidziano w tym przypadku tworzenie odpowiednich jednostek organizacyjnych na szczeblu województwa lub nawet dla grupy województw9

Aparat administracyjny państwowej służby zdrowia miał funkcjonować na trzech poziomach. Na szczeblu centralnym miało to być „Ministerstwo lub Dyrekcja z podsekretarzem stanu na czele" ${ }^{\text {", }}$, przewidziano tu zatem rozwiązanie alternatywne, nie wypowiadając się zdecydowanie za utworzeniem odrębnego resortu zdrowia. Na kolejnych niższych szczeblach miały działać wojewódzkie i powiatowe urzędy zdrowia, pod kierunkiem lekarzy wojewódzkich i powiatowych. Najniższą komórkę administracyjną, o charakterze wykonawczym, miały stanowić okręgi odpowiadające terenowo działalności poszczególnych ośrodków zdrowia, z tym że kierownik ośrodka zdrowia miała być równocześnie lekarzem okręgowym. Te jednostki organizacyjne nie stanowiły jednak części administracji państwowej, lecz miały działać na zasadzie samorządu, którego form bliżej nieokreślono. Lekarz okręgowy miał być „funkcjonariuszem samorządowym, wykonywającym zlecenia powiatowego urzędu zdrowia"

Administracja zdrowia miała być zespolona $\mathrm{z}$ administracją ogólną, ale na zasadzie pewnej samodzielności. Lekarze administracyjni mieli decydować sami w sprawach zawodowych, ponosząc $\mathrm{w}$ tych sprawach odpowiedzialność tylko wobec ,wyższej władzy fachowej, nie wobec przedstawiciela administracji ogólnej (starosty, wojewody)". W województwach i powiatach miały być utworzone rady jako organy o charakterze opiniodawczym i doradczym, w celu ,ułatwienia pracy lekarzy administracyjnych i zbliżenia ich (do) terenu"'12. Miasta powyżej 25000 mieszkańców miały posiadać własną organizację służby zdrowia, „,działającą na prawach gminy wydzielonej”, a w miastach powyżej 100000 mieszkańców administracja służby zdrowia miała mieć „prawa i przywileje powiatowego urzędu zdrowia”. Dla miasta stołecznego Warszawy przewidziano organizację służby zdrowia „równą w prawach wojewódzkiemu urzędowi zdrowia”'13.

Administracji służby zdrowia miały podlegać omówione poprzednio placówki pomocy leczniczej (szpitale, ośrodki zdrowia i gabinety lekarskie), stanowiące w stosunku do niej aparat wykonawczy. Przewidziano jednak również powierzanie określonych funkcji ,samorządom, instytucjom publicznoprawnym i organizacjom społecznym”, z tym że powinny one działać „pod kierunkiem i kontrolą" administracji państwowej ${ }^{14}$. Na uwagę zasługuje fakt, że postulowany system państwowej służby zdrowia nie eliminował prywatnej praktyki lekarskiej, pozwalał również na istnienie prywatnych lecznic i pracowni ${ }^{15}$.

\footnotetext{
${ }^{9}$ Publiczna stużba ..., p. 5 zd. 5.

${ }^{10}$ Ibidem, p. 7.

${ }^{11}$ Ibidem, p. 7 ust. 1 in fine.

${ }^{12}$ Ibidem, p. 7 ust. 2.

${ }^{13}$ Ibidem, p. 8.

${ }^{14}$ Ibidem, p. 1 ust. 2.

${ }^{15}$ Ibidem, p. 6 in fine.
} 
Nie wyłączając tej ostatniej formy zapewniania pomocy leczniczej, uznano jednak za konieczne podjęcie stanowczych środków w celu zapewnienia odpowiedniego dopływu kadr do państwowej (powszechnej) służby zdrowia. Było to tym ważniejsze, że w okresie bezpośrednio powojennym i późniejszym należało się liczyć z dramatycznym brakiem fachowych kadr w służbie zdrowia, ze względu na znaczny ubytek, zwłaszcza liczby lekarzy i pielęgniarek oraz brak możliwości jego szybkiego wyrównania. W związku z tym brano nawet pod uwagę ewentualność zatrudnienia pewnej liczby lekarzy narodowości czeskiej ${ }^{16}$. Przede wszystkim jednak narzucała się konieczność najbardziej celowego spożytkowania tych nielicznych kadr, jakie pozostaną w kraju do dyspozycji. W związku z tym przewidziano sięgnięcie do środków, o których była już mowa, w rozdziale dotyczącym zatrudnienia w zastosowaniu do różnych zawodów i specjalności o szczególnym znaczeniu dla gospodarki narodowej. Uznano mianowicie, że państwowa służba zdrowia powinna mieć prawo powoływania do świadczeń i rozsiedlania według potrzeb lekarzy i innych pracowników medycznych: dentystów, aptekarzy, pielęgniarek, akuszerek, kontrolerów sanitarnych ${ }^{17}$. Przedstawiciele tych zawodów mieli być tym samym postawieni w sytuacji pełnej dyspozycyjności w stosunku do organów służby zdrowia, co nie wykluczało jednak uprawiania przez nich prywatnej praktyki, stosownie do pozostających możliwości.

Ważną rolę miał do odegrania $\mathrm{w}$ służbie zdrowia, zgodnie $\mathrm{z}$ koncepcjami Departamentu, samorząd zawodowy, który miał współdziałać z administracją oraz brać udział w decyzjach i ponosić odpowiedzialność za stan warunków zdrowotnych w granicach objętych jego kompetencją. Samorząd ten, a ściślej biorąc samorządy różnych grup zawodowych, miał mieć wspólną reprezentację w postaci Naczelnej Izby Zdrowia i izb wojewódzkich, w ramach których działałyby autonomiczne sekcje dla poszczególnych zawodów. Przewodniczący tych izb mieli pochodzić z nominacji. Uregulowanie działalności izb zdrowia miało nastąpić w trybie rozporządzeń, których projekty nie zostały jednak opracowane ${ }^{18}$.

Osobną uwagę poświęcono szkoleniu personelu medycznego, które miało być organizowane przez same instytucje służby zdrowia bądź też przy bezpośrednim udziale ich przedstawicieli. Aprobaty organów publicznej służby zdrowia miała wymagać organizacja studiów medycznych na wyższych uczelniach, ustalanie ich programów i systemu nauczania ${ }^{19}$.

Koszty związane z powszechną opieką nad zdrowiem ludności miały ponosić samorządy terytorialne, a także Ubezpieczalnie Społeczne - w odniesieniu do leczenia osób objętych ubezpieczeniem społecznym. Przyjęcie takiej zasady

\footnotetext{
${ }^{16}$ Tezy dekretu porzadkujacego tymczasowo stan prawny w ubezpieczeniach społecznych, s. 3 , p. 1 .

${ }^{17}$ Publiczna stużba..., p. 9.

${ }^{18}$ Ibidem, p. 10.

${ }^{19}$ Ibidem, p. 11.
} 
podziału kosztów wynikało stąd, że Departament liczył się z utrzymaniem przez pewien czas odrębności lecznictwa ubezpieczeniowego, jakkolwiek co do zasady postulował jego scalenie z innymi zakresami uspołecznionego lecznictwa, $\mathrm{w}$ ramach powszechnej służby zdrowia. $Z$ funduszów państwowych miały być natomiast pokrywane koszty związane $\mathrm{z}$ utrzymywaniem administracji zarówno na szczeblu centralnym, jak terenowym (wojewódzkich i powiatowych urzędów zdrowia). Z funduszów tych miała być również subwencjonowana działalność samorządów, niebędących w stanie zaspokoić swych potrzeb w tej dziedzinie własnymi środkami ${ }^{20}$.

Tak przedstawiał się w ogólnym zarysie plan powszechnej, publicznej służby zdrowia, jaka miała być powołana do życia w przyszłej Polsce. Został on opracowany przez Departament w ogólnych liniach, bez wchodzenia w wiele spraw, od których rozstrzygnięcia zależało stworzenie optymalnego systemu organizacyjnego powszechnej służby zdrowia oraz jej prawidłowe funkcjonowanie. Należało do nich m.in. zharmonizowanie działalności placówek służby zdrowia w zakresie lecznictwa ogólnego i specjalistycznego oraz określenie struktury i kompetencji samorządu lekarzy i innych grup zawodowych czynnych w służbie zdrowia.

Przede wszystkim nasuwały się jednak kwestie związane z wprowadzeniem w życie systemu powszechnej służby zdrowia. Było bowiem rzeczą jasną, że urzeczywistnienie ogólnych planów w tym zakresie będzie musiało natrafić na wiele trudności, wynikających z niedoboru kadrowego, braku dostatecznie rozbudowanych urządzeń leczniczych, ograniczoności środków finansowych i in. W tym stanie rzeczy szczególnego znaczenia nabierało nie tyle „obmyślenie skończonego planu", co przede wszystkim wskazanie dróg prowadzących do jego urzeczywistnienia, ze wskazaniem kolejnych etapów realizacyjnych, określonych preferencji, głównych kierunków działania itp. ${ }^{21}$

W opracowaniach Departamentu liczono się ze wspomnianymi wyżej trudnościami, na co wskazuje stwierdzenie, że pełne wprowadzenie w życie powszechnej służby zdrowia będzie musiało potrwać przez dłuższy czas (mianowicie do 30 lat) oraz że musi ono być podzielone na etapy realizacyjne, które powinny być $\mathrm{z}$ góry przewidziane i planowo opracowane ${ }^{22}$. Etapy te nie zostały jednak bliżej oznaczone. Wskazano natomiast „program minimalny”, który miał być realizowany natychmiast, bezpośrednio po wojnie, oraz zadania, które powinny być wykonane nie później niż w ciągu 3 trzech.

Programem minimalnym zostało objęte utworzenie niezbędnej liczby szpitali i ośrodków zdrowia zaspokajających najpilniejsze potrzeby ludności oraz zorganizowanie bezpłatnej pomocy w nagłych wypadkach, w położnictwie, w chorobach

${ }^{20}$ Ibidem, p. 12.

${ }^{21}$ Por. J. Piotrowski, Od ubezpieczenia chorobowego do powszechnej stużby zdrowia, Łódź 1948, s. 26-27.

${ }^{22}$ Publiczna stużba..., p. 13. 
zakaźnych ostrych i przewlekłych i w zakresie opieki nad dzieckiem do ukończenia obowiązkowego okresu szkolnego, połączone z udostępnieniem środków leczniczych i opatrunkowych. Był to zatem plan oznaczający pewne preferencje, co do zaspokajania potrzeb w zakresie pomocy leczniczej. Stawiał on przy tym, zwłaszcza co do rozbudowy szpitali i ośrodków zdrowia, zadania niemożliwe do zrealizowania w krótkim czasie bezpośrednio po wojnie, tak że należało je traktować raczej jako wytyczne działania w pierwszym stadium realizacji planu. Równocześnie miały być podjęte środki w celu zapewnienia ,planowego rozsiedlenia lekarzy i całego personelu leczniczego zgodnie z potrzebami ludności”. Miało to oznaczać nałożenie na każdego lekarza, a w razie potrzeby i przedstawicieli wszystkich innych zawodów leczniczych, oddania przynajmniej części swego czasu publicznej służbie zdrowia, za wynagrodzeniem ${ }^{23}$.

Odrębnie określony został czas, w ciągu którego miało być dokonane scalenie lecznictwa ubezpieczeniowego z innymi zakresami społecznej służby zdrowia, a ściślej biorąc - przejęcie leczenia ubezpieczonych przez jednolity system tej służby. Miało to mianowicie nastąpić w ciągu 3 lat, z tym że w okresie przejściowym należało zapewnić koordynację działania (,żeby nie dopuścić do istnienia dwóch równoległych organizacji”), przy czym nadzór i ogólne kierownictwo miało być powierzone od razu publicznej służbie zdrowia ${ }^{24}$. I w tym zakresie liczono się zatem ze stosunkowo szybkim działaniem, które miało sprowadzić formy organizacyjne uspołecznionego lecznictwa do pożądanej jedności.

W opracowaniach Departamentu zabrakło bardziej szczegółowego wskazania konkretnych zadań i prac przygotowawczych, jakie miałyby wypełniać ów 30-letni okres, w ciągu którego powszechna służba zdrowia miała być w pełni ukształtowana. Sam cel, do którego należało dążyć, poprzez cząstkowe etapy realizacyjne, został jednak wyraźnie określony.

\footnotetext{
${ }^{23}$ Ibidem, p. 13.

${ }^{24}$ Ibidem, p. 14.
} 


\section{Struktura administracyjna Departamentu i plany prac naukowych}

\section{Uwagi ogólne}

W poprzednich rozdziałach przedstawiliśmy całokształt prac koncepcyjnych Departamentu, obejmujących podstawowe dziedziny polityki społecznej należące do tego resortu. Relację tę wypada uzupełnić wskazaniem na prace organizacyjne, w których wyrażała się bieżąca działalność Departamentu, prowadzona również z myślą o przyszłości. Wydaje się też ważne poinformowanie o zainteresowaniach Departamentu kierunkami przyszłych prac naukowych, służących celom polityki społecznej. Było bowiem rzeczą znamienną, że sprawom tym, pozornie bardzo odległym od rzeczywistości okupacyjnej, Departament poświęcił sporo uwagi i to zarówno w aspekcie ogólnoprogramowym, jak i instytucjonalnym.

\section{Struktury administracyjne}

Struktura organizacyjna samego Departamentu, w sensie podziału na referaty przedmiotowe i funkcjonalne, została przedstawiona we Wprowadzeniu $^{1}$. Obraz tej struktury należy jednak dopełnić wskazaniem na organizacyjne komórki

${ }^{1}$ Chodzi o Wprowadzenie do starszej wersji maszynopisu, w którym Autor napisał: „Ukształtowana ostatecznie na przełomie 1943 i 1944 roku struktura organizacyjna Departamentu przedstawiała się następująco: dyrektor Departamentu - Stefan Mateja („Żłowski”), zastępca dyrektora i kierownik referatu organizacyjnego - Wacław Szubert („Wagner”), referaty: ogólny Eugeniusz Modliński, ustroju pracy - Maciej Święcicki („Tłuchowski”), prawa pracy - Henryk Borkowski, zatrudnienia - Wacław Iwaszkiewicz („Kozłowski”), ubezpieczeń społecznych - Jerzy Piotrowski, opieki społecznej - Marian Baran, legislacyjny - Zbigniew Baucz (,Rudnicki”) oraz referaty funkcjonalne: opieki czynnej - przejściowo przez ok. 9 miesięcy w roku 1943 Wacław Szubert, następnie Stanisław Stęplewski, finansowy - N.N. („Marian”) oraz Sekretariat (Biuro): kierownik Alicja Eysmontówna („Irena”), łączniczki - Janina Gadomska („Wanda”), Hanna Pachnowska („Ewa”), maszynistka - N.N. (,Zofia”)”. 
terenowe, tworzone przy Delegatach Okręgowych, które podlegały wprawdzie służbowo tym delegatom, jednak pod względem rzeczowym zostały podporządkowane Departamentowi, który miał decydujący wpływ na kierunki i formy ich działalności. Rozległy zakres spraw objętych właściwością Departamentu sprawił, że jego terenowe odpowiedniki uległy przedmiotowemu podziałowi; przewidziano mianowicie tworzenie odrębnych okręgowych wydziałów pracy, wydziałów pomocy i opieki społecznej oraz wydziałów zdrowia, pozostających pod kierunkiem lekarzy wojewódzkich. Kierowników tych wszystkich placówek terenowych powoływał Dyrektor Departamentu, na wniosek Delegata Okręgowego. Nominacje te istotnie miały miejsce, $\mathrm{z}$ obecnej perspektywy czasu trudno byłoby jednak stwierdzić, w jakiej mierze obsada tych stanowisk została skompletowana. Trudno byłoby również odtworzyć dane personalne. Zachowały się natomiast teksty instrukcji dla kierowników wymienionych wyżej wydziałów, które dają pojęcie o charakterze ich działań. Są to dokumenty dopełniające obraz koncepcyjnych prac Departamentu, wskazaniem na sprawy o dużym znaczeniu bieżącym w czasie okupacji oraz w momencie przełomu. Wyodrębnienie tych dwóch kategorii spraw i odpowiadających im zadań cechuje wszystkie trzy instrukcje dla właściwych wydziałów okręgowych, różnią się one natomiast od siebie odmiennym ujęciem treści w kwestiach związanych z dziedziną ich działalności².

W instrukcji dla kierowników okręgowych wydziałów pracy do zadań przygotowawczych, odpowiadających bieżącej działalności w czasie okupacji, zaliczono przede wszystkim prace o charakterze organizacyjnym. Miały one polegać na przygotowaniu obsady personalnej najważniejszych stanowisk w lokalnej administracji pracy oraz utrzymywaniu kontaktu z przedstawicielami ruchu zawodowego w konspiracji i ze zrzeszeniami pracodawców, a także z kierownikami Ubezpieczalni Społecznych lub osobami przewidzianymi na te stanowiska. Drugi, równoległy zakres zadań przygotowawczych stanowić miały prace informacyjne, polegające na zbieraniu danych o stanie zatrudnienia, zmianach struktury zawodowej i warunkach życia pracowników, a także o działaniach władz okupacyjnych i reakcji społeczeństwa na te działania, opiniach lokalnych środowisk pracowników i pracodawców i in. I wreszcie trzeci zakres zadań, należących do tego samego pionu, określony został jako prace kierownicze, których istotny sens miał sprowadzać się do tego, aby kierownik wydziału pracy stał się „ośrodkiem dyspozycji społecznej na swoim terenie" ${ }^{3}$ wpływającym na wykonywanie zarządzeń władz okupacyjnych w sposób zgodny z interesami społeczeństwa polskiego, przez oddziaływanie na polski personel instytucji okupacyjnych, rozpowszechnianie odpowiednich instrukcji, uzgadnianie postępowania z kierownikami innych działów administracji itp. Na uwagę zasługuje fakt, że kierownicy

\footnotetext{
${ }^{2}$ Teksty tych instrukcji zachowały się: dla wydziałów pracy - w 2 wersjach, dla wydziału pomocy i opieki społecznej - w 3 wersjach i dla lekarzy wojewódzkich w 2 wersjach.

${ }^{3}$ Instrukcja (wydziału pracy), s. 1, pkt 3 „Prace kierownicze”.
} 
wydziałów pracy mieli również „przygotowywać społeczeństwo do prowadzeniu polityki społecznej nowego typu", wyzyskując w tym celu kontakty z zakonspirowanymi związkami zawodowymi pracowników i zrzeszeniami pracodawców. Sformułowanie tego zadania mogło budzić wątpliwości, ze względu na brak jego ukonkretnienia oraz bezpośredniego związku z kierunkami działania wymuszanymi przez rzeczywistość okupacyjną. Zawierało się w nim natomiast nawiązanie do ogólniejszych idei przewodnich polityki społecznej, wyrażonych w pracach koncepcyjnych Departamentu, które zmierzały, jak wiemy, do włączenia tej polityki w system konstruktywnych działań, składających się na oblicze przyszłej gospodarki planowej. W sprawach nieobjętych instrukcją, kierownik wydziału pracy winien był postępować w myśl interesu społecznego, porozumiewając się w sprawach większej wagi z Departamentem.

W momencie przełomu kierownik wydziału pracy miał przejąć agendy odpowiednich instytucji okupacyjnych, stając się kierownikiem połączonej administracji zatrudnienia i ochrony pracy. Do zadań jego należało niezwłoczne uruchomienie pośrednictwa pracy na nowych zasadach oraz stosownie do możliwości - pośrednictwa miejsc nauki i poradnictwa zawodowego. Najogólniejsze określenie jego zadań sprowadzało się do uznania go za wykonawcę polityki zatrudnienia na danym terenie ${ }^{5}$.

Instrukcja dla okręgowych kierowników wydziałów pomocy i opieki społecznej rozróżniała także zadania bieżące i zadania przewidywane na moment przełomu. W ramach tych pierwszych przewidywano przede wszystkim dokonanie obsady personalnej głównych stanowisk i to zarówno na szczeblu wojewódzkim, jak powiatowym i gminnym. Kierownicy wydziałów okręgowych zostali zobowiązani do rozpoznania potrzeb okręgu w zakresie opieki społecznej i opracowania planu ich zaspokojenia w najkonieczniejszym zakresie (w granicach istniejących możliwości). Po zebraniu potrzebnych materiałów kierownicy tych wydziałów mieli opracować i uzgodnić z Departamentem ,ramowy projekt swej działalności na okres najbliższy (z myślą o planowaniu również na przełom i dalszą przyszłość)" ". I w tej instrukcji zawierało się tym samym nawiązanie do ogólnych prac koncepcyjnych Departamentu w danym zakresie przedmiotowym.

Plan powyższy miał w szczególności zawierać ogólną charakterystykę terenu i jego potrzeb, opis istniejących instytucji i urządzeń oraz propozycje ich przystosowania do potrzeb i dopełnienia, charakterystykę osób, grup i zespołów o szczególnym znaczeniu i in. Działania planowe powinny zmierzać do stworzenia organizacji pomocy i opieki społecznej, odpowiadającej koncepcjom przyszłościowym Departamentu. Urzeczywistnienie tego zadania miało następować w szczególności poprzez „dążenie do osiągnięcia porozumienia wszystkich ludzi

\footnotetext{
${ }^{4}$ Ibidem, pkt $3 \mathrm{f}$.

${ }^{5}$ Ibidem, zdanie końcowe.

${ }^{6}$ Instrukcja (pomoc i opieka społeczna), s. 3.
} 
dobrej woli, łagodzenie istniejących konfliktów i zadrażnień, łączenie ludzi i grup na płaszczyźnie wspólnych wszystkim wartości, w celu uzyskania pozytywnego stosunku ogółu do zagadnień pomocy i opieki społecznej oraz wyzyskania dla pracy wszystkich twórczych sił terenu"'. Szczególny akcent padał, jak widać, na mobilizowanie i organizowanie sił społecznych wokół rozwiązywania najważniejszych zagadnień, związanych z zapewnieniem odpowiedniego zakresu działalności opiekuńczej. W momencie przełomu miało nastąpić niezwłoczne uruchomienie całego wydziału pomocy i opieki społecznej, i jemu podporządkowanych placówek na terenie poszczególnych województw. Zaznaczyć należy, że akcja tzw. opieki czynnej, sprawowanej poza opieką legalną, z funduszów Delegatury, opierała się w terenie na komórkach organizacyjnych delegatur okręgowych, które prowadziły w tym zakresie niezbędne prace wykonawcze.

Instrukcja dla lekarzy wojewódzkich wymieniała jako jedno z głównych zadań przygotowawczych, obok prac o charakterze organizacyjnym i informacyjnym, „kierowanie biegiem spraw zdrowia [...] na terenie województwa"8. W ramach tego zadania wyodrębniono stosunek do niemieckiej administracji sanitarnej, do samorządu terytorialnego (którego zakres działania niepomiernie się rozszerzył, ze względu na przejęcie aparatu zlikwidowanych organizacji społecznych) oraz do instytucji ubezpieczeń społecznych i do zawodów leczniczych. Szczególną troską lekarzy wojewódzkich miało być zachowanie polskiego stanu posiadania $\mathrm{w}$ uspołecznionym lecznictwie oraz dążenie do rozszerzenia zakresu działania istniejących placówek (szpitali, ośrodków zdrowia i in.), do odpowiedniego ich wyposażenia oraz do związania z nimi jak najliczniejszego personelu fachowego. Miał on również dbać o utrzymanie świadczeń leczniczych na właściwym poziomie oraz o sprawne funkcjonowanie placówek służby zdrowia.

W odniesieniu do przedstawicieli zawodów leczniczych, lekarz wojewódzki miał czuwać nad właściwym poziomem ich pracy zarówno pod względem etyki zawodowej, jak i ogólnoobywatelskim. W momencie przełomu lekarz wojewódzki miał niezwłocznie ustanowić państwową administrację sanitarną na poziomie I instancji, uporządkować obsadę stanowisk kierowniczych we wszelkiego rodzaju instytucjach zdrowotnych. Miały być również niezwłocznie podjęte środki w celu zapewnienia optymalnego spożytkowania kadr służby zdrowia (zakaz samowolnego opuszczania placówek służby zdrowia przez lekarzy i personel sanitarny, sporządzenie spisów lekarzy i personelu pomocniczego, znajdującego się na terenie poszczególnych powiatów, kontrola nad ewentualnym zwalnianiem lekarzy do prac na innym terenie itp.)

Przedstawiona powyżej charakterystyka aktów instrukcyjnych, przeznaczonych dla komórek terenowych Departamentu, została z rozmysłem ograniczona do ram najbardziej ogólnych. Chodziło w niej bowiem jedynie o dopełnienie

\footnotetext{
${ }^{7}$ Ibidem, s. 4, pkt 6.

${ }^{8}$ Instrukcja (dla lekarzy wojewódzkich), s. 1, pkt b.
} 
obrazu działalności Departamentu, przez wskazanie na formy działania, które miały służyć ukonkretnieniu jego prac koncepcyjnych i powiązaniu ich z zadaniami podejmowanymi bieżąco $\mathrm{w}$ okresie okupacji i przewidywanymi w jej momencie końcowym. Szersze rozwinięcie tego wątku nie mieściłoby się już w koncepcji niniejszej pracy i wymagałoby zastosowania innych metod badawczych, nie mówiąc o trudnościach, na jakie musiałoby natrafić pozyskanie odpowiedniego materiału informacyjnego.

\section{Plany prac naukowych}

Zainteresowania Departamentu organizacją i kierunkiem prac naukowo-badawczych w dziedzinie polityki społecznej nieprzypadkowo skupiły się wokół przyszłej roli i zadań Instytutu Spraw Społecznych w Warszawie. Instytut ten stanowił bowiem przed wojną naturalne środowisko tego rodzaju prac oraz miał wszelkie dane dla rozwinięcia ich w przyszłości. Utworzony w 1931 r., jako fundacja instytucji ubezpieczeń społecznych, nie ograniczył się do prowadzenia prac naukowych interesujących bezpośrednio te instytucje, lecz rozszerzył je także na problematykę rynku pracy i bezrobocia, opieki społecznej, zdrowia publicznego, ustroju pracy, nie mówiąc już o zagadnieniach bezpieczeństwa i higieny pracy, ujmowanymi w szerszym aspekcie kultury pracy, które skupily na sobie szczególną uwagę Instytutu, który wniósł do tej dziedziny wiele twórczej myśli i inicjatywy. W ciągu 8-letniego zaledwie okresu swej działalności przed wojną Instytut zdołał skupić wokół siebie grono wybitnych specjalistów, czerpiących wiedzę zarówno z badań, jak i z praktyki życia, wykazał się również znaczącym dorobkiem wydawniczym, dotyczącym różnych zagadnień polityki społecznej. Ze względu na ścisłe powiązanie z instytucjami ubezpieczeń społecznych, a także z Funduszem Pracy oraz z Ministerstwem Opieki Społecznej, które sprawowało ogólny nadzór nad jego działalnością, Instytut pozostawał w bezpośrednim kręgu czynników kształtujących oblicze naszej polityki społecznej, będąc równocześnie powołanym do spełniania w tym zakresie inspirującej roli. Był tym samym placówką predestynowaną do uprawiania nauki polityki społecznej, pojętej jako dyscyplina praktyczna, służąca gromadzeniu wiedzy przydatnej przy określaniu kierunków działania oraz dobieraniu optymalnych środków do osiągnięcia założonych celów. Tę rolę Instytut Spraw Społecznych spełniał już w znacznej mierze przed wojną, jednak rozwinięcie jej w przyszłości wydawało się szczególnie ważne, zwłaszcza w obliczu postulowanych przemian charakteru polityki społecznej i przewidywanego powiązania jej z gospodarką planową.

W okresie wojny Instytut doznał ciężkich strat. Przerzedziły się przede wszystkim w sposób tragiczny, i to już na samym jej początku, kadry fachowych współpracowników Instytutu. Dotknęło to niestety również człowieka, który stał 
na czele Instytutu od chwili jego powstania i był, bez przesady, duszą jego prac. Legalne prowadzenie jakichkolwiek prac badawczych, a tym bardziej wydawniczych stało się oczywiście niemożliwe. Poważnym problemem było zachowanie samej substancji aparatu badawczego: biblioteki, materiałów będących w opracowaniu, rękopisów.

Tę ostatnią kwestię udało się do czasu rozwiązać przez zakamuflowanie Instytutu pod postacią warsztatu szewskiego, z którym związały się na zasadzie mniej lub bardziej stabilnej współpracy pewne kręgi inteligencji i świata artystycznego. Wnosiło to do funkcjonowania tej placówki pewne treści ideowe ${ }^{9}$, nie dawało natomiast szans kontynuowania, choćby w ograniczonej formie, właściwej działalności Instytutu, tym bardziej że jego personel fachowy uległ rozproszeniu.

Sprawa ta stała się natomiast przedmiotem zainteresowania Departamentu, do czego przyczynił się fakt, że w jego ramach znalazło się paru dawnych współpracowników Instytutu, którzy uczestniczyli już przed wojną w prowadzonych przezeń badaniach. Luźne rozmowy na ten temat prowadzone w Departamencie przerodzily się z czasem w zorganizowaną wymianę zdań i znalazły wyraz w postaci pisanych dokumentów, noszących wprawdzie charakter indywidualnych notatek, ale składających się w sumie na pewną całość, w której zarysowały się wyraźnie myśli przewodnie, dotyczące przyszłego kształtu Instytutu Spraw Społecznych i głównych kierunków jego prac ${ }^{10}$.

Zaznaczyła się w nich przede wszystkim koncepcja rozszerzenia zakresu działania Instytutu na wszystkie podstawowe zakresy polityki społecznej i pełniejszego uwzględnienia zagadnień niezwiązanych bezpośrednio z ubezpieczeniami społecznymi, które stanowiły przed wojną centralną dziedzinę jego zainteresowań. Postulowano również stworzenie ściślejszych powiązań pomiędzy pracami Instytutu a działalnością programową Ministerstwa Pracy i Opieki Społecznej tak, aby Instytut mógł odegrać aktywną rolę w kształtowaniu dróg rozwojowych polityki społecznej i być bezpośrednio pomocnym w rozwiązywaniu konkretnych zagadnień.

Równocześnie akcentowano jednak mocno treści ideowe przyszłej pracy Instytutu stwierdzając, że powinien on stać się „twórczym ośrodkiem myśli społecznych zdolnych do wzbudzenia żywego oddźwięku w opinii publicznej i do przemiany w rzeczywistość" ${ }^{11}$. Wychodząc z tych samych założeń, formułowano „naczelny problem Instytutu” jako „problem wyzwolenia czynnego uczestnictwa

${ }^{9}$ Instytut Spraw Społecznych przy Asfaltowej, [w:] Wspomnienia warszawskich peperowców, Warszawa 1963, s. 190 i n.

${ }^{10}$ Dokumenty te zostały opublikowane pt. Trójgłos o Instytucie Spraw Spolecznych w Warszawie z okresu okupacji, „Studia i Materiały z Historii Ubezpieczeń Społecznych w Polsce” (Warszawa) 1986, z. 4, s. 157-176.

${ }^{11}$ Ibidem, s. 170. 
mas pracowniczych w twórczych procesach budowania kultury narodowej". Wiązało się z tym ściśle kształtowanie „podstaw ideologii społeczno-kulturalnej Polski, wzorów osobniczych postaw, bodźców do działalności, instytucji, które by dawały upust narastającej energii społecznej" ${ }^{12}$. Refleksja nad przyszłą rolą Instytutu Spraw Społecznych wiązała się z uświadomieniem sobie faktu, że po wojnie trzeba będzie nie tylko budować domy, drogi i warsztaty, lecz także „splatać nowe więzi w stosunkach społecznych, [...] zaciągać je z nowych tworzyw, z innych materiałów”, a w tym celu sięgać do głębokich „pokładów ludzkiej myśli i odczuwań”, „tworzyć zręby nowych rozwiązań, wskaźniki wytyczające nowe tory na drodze rozwoju zjawisk społecznych"13.

Wśród zagadnień o charakterze kluczowym, na których powinna skupić się przede wszystkim działalność Instytutu, wskazywano problematykę pracy ludzkiej, sprawę wyzwalania twórczej i odpowiedzialnej postawy w pracy, odpowiedniego przygotowania do pracy zawodowej i wyzwolenia energii młodzieży, wzmocnienia społecznej roli warsztatów wytwórczych, podkreślano też kluczowe znaczenie demokracji „w różnych przejawach życia ludzkiego, od najdrobniejszych jego komórek do organizacji państwowej”"14.

Zdając sobie sprawę z rozległości tej problematyki, którą trudno byłoby objąć od razu pełnym opracowaniem, postulowano koncentrację sił na poszczególnych zagadnieniach branych na warsztat Instytutu, które powinny być stopniowo wprowadzane na tory realizacji. Równocześnie postulowano zacieśnienie współpracy z innymi instytucjami naukowo-badawczymi, a zwłaszcza z uczelniami wyższymi (brak tej ostatniej współpracy był słabą stroną przedwojennej działalności Instytutu).

Wskazywano też różne zagadnienia bardziej szczegółowe, które powinny stać się przedmiotem szczególnego zainteresowania Instytutu w okresie powojennym, takie jak: metody, zakres i kierunki szkolenia zawodowego, rzeczowe kryteria dla odrębnego traktowania różnych grup pracowniczych na gruncie prawa pracy, odrębności pracy fizycznej i umysłowej w związku z postulatem równych szans, wpływ różnych systemów polityki płac na uaktywnienie postaw pracowniczych, podstawowe zagadnienia ruchu zawodowego, skuteczność i rola społecznej akcji opiekuńczej $\mathrm{i}$ in. ${ }^{15}$

Wśród postulatów sformułowanych przez Departament znalazło się również podjęcie pewnych prac badawczych już w czasie okupacji, a w szczególności gromadzenie materiałów obrazujących ówczesną rzeczywistość społeczną i krytyczne przejrzenie dorobku prac przedwojennych, niedoprowadzonych do końca pod kątem celowości ich wykorzystania i kontynuacji. Prace tego rodza-

\footnotetext{
${ }^{12}$ Ibidem, s. 173.

${ }^{13}$ Ibidem, s. 170.

${ }^{14}$ Ibidem, s. 171.

${ }^{15}$ Ibidem, s. 167-168.
} 
ju mogły być cennym uzupełnieniem prac badawczych, prowadzonych w czasie wojny przez Instytut Gospodarstwa Społecznego, pod formą komisji statystycznej RGO w Warszawie, a także działalności informacyjnej odpowiednich komórek Delegatury Rządu i Armii Krajowej (Departament Informacji i Prasy, Wydział Informacji BIP AK). Do podjęcia tych prac jednak nie doszło, a następnie gmach Instytutu ze wszystkimi zbiorami uległ spaleniu. Po wojnie Instytut Spraw Społecznych nie został wskrzeszony, rolę jego podjęły natomiast w różnym zakresie placówki o charakterze uczelnianym i resortowym.

Opracowania programowe Departamentu pozostają natomiast dokumentem świadczącym o zrozumieniu znaczenia prac badawczych w dziedzinie polityki społecznej, jako niezbędnego oparcia dla praktycznych poczynań w tej dziedzinie. 


\section{Zakończenie}

W kolejnych rozdziałach niniejszej pracy dokonaliśmy przeglądu idei programowych i koncepcji Departamentu Pracy i Opieki Społecznej w odniesieniu do różnych zakresów polityki społecznej i prawa pracy. Zamykając nasze rozważania, wypada spojrzeć na te koncepcje jako na pewną całość oraz podjąć próbę oceny ich wartości z dłuższej perspektywy czasu, jaki upłynął od lat, gdy były one formułowane. Przystępując do tej oceny, należy przede wszystkim stwierdzić, że idee te nie stanowiły ogólniejszego politycznego programu, postulowały natomiast wiele konkretnych przemian w różnych dziedzinach życia społecznego, które miały prowadzić do stworzenia nowej sytuacji świata pracy. Formułowaniu tych idei nie towarzyszyły hasła zmiany ustroju społeczno-gospodarczego, było jednak rzeczą oczywistą, że ich urzeczywistnienie będzie musiało spowodować głębokie przeobrażenie o charakterze jakościowym w porównaniu z systemem, jaki istniał w okresie międzywojennym. W jakiej mierze koncepcje te wytrzymały próbę czasu i o ile znalazły potwierdzenie w późniejszym doświadczeniu?

Odpowiedź na to pytanie zależy od kryteriów oceny. Jeśli przyjąć za takie kryterium zgodność późniejszego rozwoju sytuacji społecznej z postulatami Departamentu, to trzeba stwierdzić, że wystąpiła ona istotnie w dość szerokim zakresie. Mniej istotna jest $\mathrm{z}$ tego punktu widzenia trafność przewidywań Departamentu, dotyczących okresu przejściowego, gdyż szczególne warunki i potrzeby tego okresu zarysowywały się w końcowej fazie wojny w sposób dość oczywisty. Posunięcia takie, jak ograniczenie swobody wyboru miejsc pracy w deficytowych zawodach czy stosowanie przyspieszonych metod szkolenia zawodowego, dla częściowego zaradzenia brakowi kwalifikowanych kadr, narzucały się same przez się; zostały też istotnie w praktyce podjęte, jakkolwiek nie od razu po wojnie, lecz dopiero w początkowej fazie forsownego uprzemysłowienia (1951). To samo dotyczy odpowiednio polityki płac okresu przejściowego, nacechowanej szerokim stosowaniem deputatów i dodatków rodzinnych, czy też struktury świadczeń rentowo-emerytalnych wymierzanych jednolicie poniżej skromnego minimum egzystencji, czy wreszcie szerokiego rozwinięcia różnych form opieki społecznej. 
Ważniejsze od spraw okresu przejściowego były jednak idee i koncepcje określające trwalsze podstawy porządku społeczno-gospodarczego w przyszłej Polsce. W tym zakresie dostrzegamy również urzeczywistnienie wielu myśli programowych Departamentu, z tym że praktyka nie zawsze odpowiadała ściśle ich treści. Zrealizowane zostało prawo do pracy w sensie likwidacji zjawiska bezrobocia, ale za cenę dopuszczenia do nieracjonalnego zatrudnienia i podważenia dyscypliny pracy. Dokumenty opracowane przez Departament świadczyły o dążeniu do innego rozwiązania tego problemu, przy którym polityka pełnego zatrudnienia nie stwarzałaby warunków ułatwionego życia przy małym nakładzie wysiłku, lecz opierałaby się na lepszym zrównoważeniu prawa do pracy i obowiązku pracy.

Zgodne z postulatami Departamentu było zniesienie niesprawiedliwych linii podziału w porządku prawnym, w szczególności podziału na robotników i pracowników umysłowych, z tym że reforma ta została przeprowadzona w pełnym zakresie dopiero blisko 30 lat po wojnie, wówczas gdy Departament wypowiadał się za dokonaniem jej znacznie szybciej i w sposób bardziej radykalny. Poza tym reforma ta nie doprowadziła do oparcia dyferencjacji prawa pracy w całości na kryteriach rzeczowych; niektóre problemy pozostają zatem w tej dziedzinie nadal do rozwiązania.

Model społecznej służby zdrowia ukształtował się, ogólnie rzecz biorąc, na zasadach postulowanych przez Departament, z tym że jego całkowite upowszechnienie natrafiło na wiele trudności i nie zostało dotychczas w pełni dokonane, jakkolwiek upłynął już od końca wojny znacznie dłuższy okres od przewidywanego przez Departament dla doprowadzenia tej reformy do końca (miało to być 30 lat). Zakres ubezpieczeń społecznych został natomiast rozciągnięty praktycznie na całą ludność pracującą, z tym że nastąpiło to stopniowo, poprzez częściowe reformy, dopiero w latach siedemdziesiątych.

W wielu zakresach, w których rozwój polityki społecznej poszedł w kierunku przewidywanym przez Departament, idee jego pozostają nadal żywe i mogą służyć jako wytyczne działania. Odrębnej oceny wymaga znaczenie idei Departamentu w tych dziedzinach, w których powojenna polityka społeczna została oparta na zasadach różniących się zdecydowanie od postulowanych przez Departament. Tutaj bowiem idee te ukazują wartości nieprzyjętych rozwiązań oraz rzucają wiele światła na złożone uwarunkowania różnych zakresów polityki pracy w ich wzajemnych powiązaniach. Dotyczy to w szczególności sprawy o znaczeniu tak kluczowym, jak struktura i charakter ruchu zawodowego i organów reprezentacyjnych świata pracy. W koncepcji Departamentu miały one stanowić podstawę ustroju opartego na pracy. Stąd też poszukiwano rozwiązań, które zapewniłyby im odpowiednio mocną pozycję, przy równoczesnym zachowaniu wewnętrznej autonomii i niezależności. Znamienne było zwłaszcza dążenie do konsolidacji ruchu zawodowego, w skojarzeniu z wolnością związkową i pluralizmem form organizacyjnych. Duże znaczenie miało również postulowanie rozbudowy struktur 
samorządowych, jako przeciwwagi dla państwowego aparatu biurokratycznego $\mathrm{w}$ gospodarce planowej, a także stworzenia autentycznego samorządu w ubezpieczeniach społecznych. Idee te zachowują nadal dużą siłę atrakcyjną oraz żyją w świadomości szerokich rzesz pracowniczych.

Jeden jeszcze wątek w pracach koncepcyjnych Departamentu zasługuje na bliższą uwagę, a mianowicie dążenie do oparcia rozwoju polityki społecznej na zasadach planowania. Postulowana przez Departament planowość gospodarki musiała znaleźć odbicie $\mathrm{w}$ dziedzinie jego bezpośrednich zainteresowań, a w szczególności w polityce zatrudnienia i płac. W dokumentach Departamentu zaznacza się to wyraźnie. Treść ich wykazuje dowodnie, że z planowością działania w zakresie polityki gospodarczej i społecznej wiązane były daleko idące oczekiwania, co do możliwości rozwiązania na tej drodze trudnych zagadnień życia społecznego oraz skutecznego pokierowania jego rozwojem.

Późniejsze doświadczenia miały wnieść w tę dziedzinę wiele sceptycyzmu. Zapanowanie nad żywiołowością wielu procesów okazało się bowiem znacznie trudniejsze, niż mogłoby się wydawać, a dążenia do nadania im określonego kierunku nie zawsze przynosiły wyniki odpowiadające zamierzonym. Dotyczyło to w szczególny sposób polityki zatrudnienia, obejmującej całość gospodarki siłami ludzkimi, oraz polityki płac, które Departament zamierzał oprzeć na zasadach racjonalności i podporządkować zobiektywizowanym kryteriom. Środki działania, jakie w koncepcji Departamentu miały służyć temu celowi, mogą z obecnego punktu widzenia budzić wątpliwości. W związku z tym warto zaznaczyć, że przecenianie możliwości planowania było rozpowszechnione wśród przedstawicieli postępowej myśli społecznej, poszukującej dróg głębszej przebudowy. Wystąpiło ono zresztą także w latach bezpośrednio powojennych przed wejściem na drogi praktycznej realizacji.

Te ostatnie stwierdzenia prowadzą do kolejnej refleksji: nad źródłami koncepcji i poglądów wyrażanych przez Departament i ośrodkami myśli, które wywarły wpływ na jego prace i kierunki poszukiwań. W dotychczasowych rozważaniach nie poruszaliśmy tego wątku, poza wskazaniem na literaturę charakteryzującą sytuację społeczno-gospodarczą przedwojennej Polski. Wpływ tej literatury na stanowisko zajmowane przez Departament wobec podstawowych problemów polityki społecznej był niewątpliwy. Wydawnictwa, takie jak Młodzież sięga po pracę czy Bezrobocie wśród chlopów, obok wielu innych publikacji Instytutu Gospodarstwa Społecznego i Instytutu Spraw Społecznych, tkwiły mocno w świadomości współpracowników Departamentu i skłaniały do zasadniczego przekształcenia charakteryzowanej w nich rzeczywistości.

Bezpośrednich inspiracji do kierunków owych poszukiwań dostarczały natomiast idee formułowane przez wybitnych przedstawicieli polskiej myśli społecznej. Należał do nich zwłaszcza Konstanty Krzeczkowski, ojciec polskiej nauki polityki społecznej, którego idee wypowiadane w licznych pracach publikowanych w okresie międzywojennym, a zwłaszcza w podstawowej książce 
Idee przewodnie ubezpieczeń społecznych, przemawiały głęboko do świadomości tych środowisk, z jakich rekrutowali się współpracownicy Departamentu. Jego wizja gospodarki planowej, zrodzona z „tęsknot za najdoskonalszym ustrojem”, jego plany - polegające na „wcieleniu instytucji ubezpieczeń społecznych (ale koncepcje te miały również szerszy zakres odniesienia) w organizm planowego gospodarstwa" ${ }^{\prime}$ - znajdowały silny rezonans w zespołach ludzi o tym obliczu ideowym, jakie reprezentował Departament.

Dodajmy jeszcze, że ta nowa forma ustrojowa, mająca być „przezwyciężeniem determinizmu sił gospodarczych na rzecz swobodnej twórczości ludzkiej”, zakładała w koncepcji K. Krzeczkowskiego uaktywnienie mas ${ }^{2}$ oraz szeroką rozbudowę struktur samorządowych jako podstawę „świadomej i planowej akcji”, mobilizującej siły społeczne do dzieła wielkiej przebudowy. W koncepcjach tego samorządu, ogarniającego różne dziedziny życia społecznego, znajdowała wyraz idea demokracji czynnej, której wyrazicielem był K. Krzeczkowski, nawiązując w tym do innych przedstawicieli polskiej myśli społecznej, w szczególności do Edwarda Abramowskiego. Są wszelkie dane, aby sądzić, że koncepcje te wywarły wpływ na projekty Departamentu, zmierzające do stworzenia szeroko zakrojonych struktur samorządu społeczno-gospodarczego, w którym miał odegrać poważną rolę samorząd pracy.

Do rozważenia byłaby kwestia, czy w ideach programowych Deparatementu nie można by się dopatrzeć również wpływu Georges'a Sorela, który oddziałał, jak wiadomo, na wielu przedstawicieli polskiej myśli społecznej, wśród nich na K. Krzeczkowskiego ${ }^{3}$, a w okresie okupacji, rzecz znamienna, należał do myślicieli, których idee znajdowały szeroki rezonans ${ }^{4}$. Dotyczyło to również środowiska współpracowników Departamentu, w którym prace G. Sorela były przedmiotem wewnętrznych dyskusji. Istniały też powiązania poprzez osobę Jerzego Piotrowskiego - jednego z pracowników Departamentu - z ruchem syndykalistycznym ${ }^{5}$. Wydaje się jednak, że można tu mówić raczej o ogólniejszych inspiracjach, dotyczących zwłaszcza aktywnej roli ruchu zawodowego w ramach ustroju opartego na pracy, aniżeli o bezpośrednim wpływie na określone koncepcje programowe w dziedzinie polityki społecznej.

Trzeba natomiast wskazać na zbieżność idei przewodnich Departamentu z koncepcjami przedwojennej postępowej myśli ekonomicznej, jakie reprezentował Michał Kalecki czy zwłaszcza Oskar Lange. Bliska poglądom Departamentu była w szczególności wyrażona przez tego ostatniego idea „rzeczypospolitej

\footnotetext{
${ }^{1}$ K. Krzeczkowski, Idee przewodnie ubezpieczeń społecznych, Warszawa 1936, s. 183.

${ }^{2}$ W. Szubert, Konstanty Krzeczkowski jako polityk społeczny, [w:] K. Krzeczkowski, Polityka społeczna. Wybór pism, Łódź 1947, s. LVII-LVIII.

${ }^{3}$ Ibidem, s. LVIII.

${ }^{4}$ Por. Z. Zbyszewska, Ministerstwo polskiej biedy, Warszawa 1983, s. 262.

${ }^{5}$ S. Lewandowska, Polska konspiracyjna prasa informacyjno-polityczna 1939-1945, Warszawa 1982, s. 107-108.
} 
socjalistycznej”, w której zarząd gospodarczy byłby oddzielony od władzy politycznej, a samorząd mas pracujących miałby przeniknąć wszystkie dziedziny życia społecznego ${ }^{6}$. Brak wprawdzie danych dla stwierdzenia, aby koncepcje O. Langego oddziałały bezpośrednio na prace Departamentu, jednakże wpływ postępowej myśli ekonomicznej z lat przedwojennych na postulowane w nich kierunki przemian wydaje się niewątpliwy. Nie bez znaczenia był z tego punktu widzenia fakt, że w wewnętrznych dyskusjach współpracowników Departamentu uczestniczył Edward Lipiński.

$\mathrm{Na}$ jeszcze jedno źródło inspiracji, spokrewnione z syndykalizmem, należy wskazać jako zasługujące na szczególną uwagę. Była to grupa „Jutra Pracy” uformowana na kilka lat przed wojną w ramach tzw. lewicy sanacyjnej, w której szczególną rolę odgrywał Jan Hoppe 7 . Było to źródło tym ważniejsze, że idee reprezentowane przez tę grupę znalazły $\mathrm{w}$ okresie okupacji kontynuację $\mathrm{w}$ organizacji „Unia”, która skupiła grono wybitnych intelektualistów zainteresowanych sprawą przebudowy społecznej. Czerpała ona swe myśli programowe z założeń chrześcijańskiej myśli społecznej, była jednak szeroko otwarta również dla przedstawicieli innych kierunków ideowych. Postulaty wypracowane w tym środowisku zmierzały do „uspołecznienia państwa” i stworzenia „powszechnego samorządu narodu", nie ograniczając się przy tym do ogólnych wytycznych, lecz kreśląc również projekty reform, w których dużą rolę odgrywało stworzenie struktur samorządowych obejmujących izby pracy. Jak widać, w środowisku tym zrodziły się idee bliskie koncepcjom Departamentu, rozwiniętym w postaci projektów odpowiednich aktów normatywnych. Trzeba przy tym dodać, że aktywnym uczestnikiem prac koncepcyjnych „Unii” oraz członkiem jej Rady Programowej był dyrektor Departamentu Stefan Mateja9. Stwarzało to bezpośrednią łączność personalną i równoległość niektórych prac prowadzonych w obu tych środowiskach. Były one częściowo zbieżne w swych założeniach dotyczących przyszłego ustroju pracy, z tym że w Departamencie przybrały formy znacznie bardziej ukonkretnione. Dla pełnej jasności należy dodać, że między tymi dwoma środowiskami nie było w okresie wojny żadnej zorganizowanej łączności, a nawet fakt uczestniczenia S. Matei w „Unii” nie był, ze względu na ówczesne zasady konspiracji, znany współpracownikom Departamentu.

Prace koncepcyjne Departamentu rozwijały się na pograniczu polityki społecznej i prawa pracy, wkraczając w bardzo poważnej mierze w tę ostatnią dziedzinę, która przed wojną nie uzyskała jeszcze prawa obywatelstwa, jako odrębna gałąź prawa i dyscyplina naukowa. W skromnym dorobku publikacyjnym z tamtego

${ }^{6}$ O. Lange, Wizje gospodarki socjalistycznej, Warszawa 1985, s. 251 i 253.

${ }^{7}$ Por. J. Hoppe, Samorzad pracy, Warszawa 1932, a także idem, Wspomnienia, przyczynki, refleksje, Londyn 1972, s. 65, 111.

${ }^{8}$ Ibidem, s. 283-285, 289.

${ }^{9}$ Ibidem, s. 275, 299. 
okresu znalazły się jednak prace, które mogły dostarczyć Departamentowi pewnych inspiracji. Należał do nich podręcznik Zygmunta Fenichela wydany w 1930 r., który poza zreferowaniem ówczesnego stanu prawnego na tle porównawczym, podejmował również niektóre ogólniejsze zagadnienia prawa pracy, a w szczególności jego umiejscowienia na pograniczu prawa prywatnego i publicznego ${ }^{10}$; a więc wkraczał w problematykę budzącą szczególne zainteresowanie Departamentu. Ważniejsze jeszcze z tego punktu widzenia były publikacje Jerzego Wengierowa, dotyczące różnych form przedstawicielstwa pracowniczego, w których formułowane były koncepcje przyszłych dróg rozwojowych i form organizacyjnych ruchu zawodowego, bliskie niektórym ideom wyrażonym w tezach programowych i w projektach aktów legislacyjnych, opracowanych przez Departament ${ }^{11}$.

$\mathrm{Na}$ osobną wzmiankę zasługuje inicjatywa, podjęta na krótko przed wojną, wydawania specjalnego periodyku, poświęconego omawianej dyscyplinie prawniczej, pod nazwą „Przegląd Prawa Pracy”. Postawił on sobie za cel pogłębienie wiedzy i służenie realizacji zadań polityki społecznej oraz stopniowe przygotowywanie gruntu dla kodyfikacji tej gałęzi prawa poprzez „,przepracowywanie poszczególnych jego instytucji"' ${ }^{2}$. Na łamach 11 numerów tego czasopisma, jakie ukazały się w latach 1938-1939, opublikowano wiele cennych artykułów, poświęconych problematyce polityki społecznej i prawa pracy, zatargom zbiorowym pracy, sądom pracy, przedstawicielstwu pracowniczemu w zakładach pracy, sytuacji prawnej różnych grup pracowniczych. Należy przy tym podkreślić, że w skład członków Komitetu Redakcyjnego tego pisma wchodzili Stefan Mateja i Maciej Święcicki, a sekretarzem jego był Henryk Borkowski; zatem późniejsi pracownicy Departamentu brali w nim bezpośredni udział.

Przejawem zdobywania samodzielnej pozycji przez prawo pracy była zapowiedź zorganizowania po raz pierwszy odrębnej Sekcji Prawa Społecznego w ramach XXIV Zjazdu Prawników Polskich, jaki miał obradować we wrześniu 1939 r. w Gdyni. Autorem jednego z dwóch referatów, mających być przedmiotem obrad tej sekcji pt. Obowiazki pracodawcy w zakresie opieki nad pracownikiem, był S. Mateja ${ }^{13}$, co świadczy pośrednio o uzyskanej przez niego pozycji w środowisku prawniczym, reprezentującym tę dyscyplinę.

Spostrzeżenia powyższe pokazują, że prace koncepcyjne Departamentu były głęboko osadzone w dorobku polskiej myśli społecznej i prawniczej, nawiązując w wielu wątkach do jej twórczego nurtu. Pracownicy Departamentu byli na ogół zbyt młodzi, aby mogli zaznaczyć już przed wojną swój poważniejszy udział

${ }^{10}$ Z. Fenichel, Zarys polskiego prawa robotniczego, Kraków 1930, s. 22 i n.

${ }^{11}$ J.G. Wengierow, Przedstawicielstwo pracownicze a państwo, Warszawa 1935.

${ }^{12}$ Stowo wstepne, „Przegląd Prawa Pracy” 1938, nr 1, s. 2.

${ }^{13}$ Praca ta zachowała się w maszynopisie i częściowo w odbitce korektorskiej z 1939 r., por. przypis 66 , rozdział I. 
w ówczesnych pracach koncepcyjnych i naukowych, znaleźli się jednak w środowiskach reprezentujących postępową myśl społeczną i po części wnosili już swój wkład do jej dorobku.

Prowadzone natomiast przez nich prace koncepcyjne w czasie wojny stanowiły w pewnej mierze kontynuację tamtych wątków ideowych, przynosząc dorobek niewykończony wprawdzie w niektórych dziedzinach i nierówny pod względem stopnia konkretyzacji, mający jednak niewątpliwie oryginalne wartości.

W okresie powojennym te ciągi rozwojowe podlegają komplikacji. Rozwój polityki społecznej i prawa pracy zostaje oparty na innych założeniach niż przyjmowane przez Departament. Dorobek jego prac koncepcyjnych i projektów legislacyjnych nie mógł być w tych warunkach bezpośrednio przydatny. Niektóre regulacje prawne i kierunki rozwiązań odpowiadają jednak, jak to już stwierdzono, przewidywaniom i zamierzeniom Departamentu. A ponadto dorobek myśli zawartej $\mathrm{w}$ jego opracowaniach jest nadal rozwijany $\mathrm{w}$ indywidualnych pracach niektórych jego pracowników, podejmowanych i publikowanych bezpośrednio po wojnie.

J. Piotrowski rozwija swe koncepcje budowy uspołecznionego lecznictwa i ubezpieczeń społecznych w wydanej w 1948 r. książce pt. Od ubezpieczenia chorobowego do powszechnej stużby zdrowia. Warto przy tym zaznaczyć, że był on w tym czasie czynny jako rzeczoznawca w Zakładzie Ubezpieczeń Społecznych, a następnie jako przewodniczący międzyministerialnej komisji do spraw reformy ubezpieczenia społecznego ${ }^{14}$. M. Święcicki wydaje w 1949 r. pierwszy powojenny podręcznik prawa pracy, w którym znajdują rozwinięcie niektóre idee wyrażone $\mathrm{w}$ tezach o indywidualnym prawie pracy z czasu wojny ${ }^{15}$. Warto też wskazać na jego publikację z tego samego roku dotyczącą rad zakładowych ${ }^{16}$, do której wzbogacenia przyczyniły się jego przemyślenia z okresu wojennych prac nad tą problematyką. Wacław Szubert rozwija zagadnienia konstruktywnej polityki społecznej w publikacji z 1947 r. ${ }^{17}$ oraz w swych wykładach na Uniwersytecie Łódzkim. Trzeba też wskazać na działalność, powstałego wkrótce po wojnie w Łodzi, Polskiego Instytutu Służby Społecznej, który wydał wspomnianą już książkę J. Piotrowskiego oraz zainicjował serię pod nazwą „Biblioteka Myśli Społecznej”, w ramach której ukazał się wybór prac K. Krzeczkowskiego, poprzedzony charakterystyką jego życia i prac naukowych.

Można by tym samym stwierdzić, że ciągłość myśli nawiązujących do dorobku Departamentu uległa przedłużeniu na lata powojenne, co świadczyło pośrednio

${ }^{14}$ W. Szubert, Zastużeni dla rozwoju ubezpieczeń społecznych. Jerzy Piotrowski (1907-1983), „Studia i Materiały z Historii Ubezpieczeń Społecznych w Polsce” (Warszawa) 1986, z. 4, s. $178-179$.

${ }^{15}$ M. Święcicki, Prawo stosunku pracy. Zarys systemu, Częstochowa 1949.

${ }^{16}$ M. Święcicki, Rady zakładowe jako organy ruchu zawodowego, „Państwo i Prawo” 1949, nr 9-10.

${ }^{17}$ W. Szubert, Nowe drogi polityki społecznej, „Myśl Współczesna” 1947, nr 11, odbitka. 
o ich żywotności i utrzymującej się sile atrakcyjnej. W pewnym sensie ten ciąg okazał nawet dalszą trwałość w postaci późniejszych publikacji wymienionych wyżej autorów, dotyczących tej samej lub pokrewnej tematyki. W tej fazie ciągi rozwojowe wyrażonych przez nich myśli ulegają jednak dalszemu skomplikowaniu ze względu na to, że oddziaływały na nie już nowe doznania i inspiracje.

Nie byłoby tym samym uzasadnione przypisywanie pracom koncepcyjnym Departamentu trwalszego znaczenia od tego, jakie było zdeterminowane ich charakterem oraz warunkami, w jakich były prowadzone. Umiejscowione w tych warunkach i czasie ukazują one jednak szersze horyzonty myśli poszukującej dróg przebudowy społecznej oraz pozostają w tym zakresie dokumentem, który nie powinien ulec zapomnieniu. 


\section{Aneks I}

\section{Waclaw Szubert \\ Departament Pracy i Polityki Społecznej Delegatury Rządu (1941-1945) - organizacja i dzialalność \\ (przedruk z „Kultura i Społeczeństwo” 1990, t. XXXIV, nr 2)}

Departament Pracy i Opieki Społecznej był w ramach Delegatury Rządu na Kraj jednostką o szczególnym profilu i charakterze. Ciążyły na nim wprawdzie, ogólnie rzecz biorąc, te same zadania, co na wszystkich departamentach Delegatury, polegające na przygotowaniach do opanowania sytuacji w momencie przełomu i w pierwszym okresie odbudowywania polskiej państwowości. Temu celowi podporządkowane były głównie prowadzone w Departamencie prace o charakterze dokumentacyjnym i koncepcyjnym, a także organizacyjnym, połączone z planowaniem przyszłych struktur administracji pracy i jej obsady personalnej'.

Różne okoliczności wpłynęły jednak na odrębne ukształtowanie się oblicza Departamentu oraz na podniesienie jego znaczenia. W ramach Departamentu przede wszystkim została zorganizowana i w ciągu kilku lat (1941-1945) była prowadzona akcja tak zwanej opieki czynnej, polegającej na niesieniu pomocy ofiarom terroru okupacyjnego i wartościowym społecznie jednostkom oraz członkom ich rodzin. Akcja ta przybrała z czasem szerokie rozmiary i angażowała stale rosnące fundusze, przy czym Departament odgrywał rolę centralnego ośrodka dyspozycji i rozdziału środków oraz określał zasady i formy udzielanej pomocy, odpowiednio do potrzeb i warunków.

O szczególnej pozycji Departamentu decydował również charakter reprezentowanego przezeń „resortu”. Problemy pracy miały bowiem centralne znaczenie w kształtowaniu przyszłego ładu społecznego, któremu miały

\footnotetext{
${ }^{1}$ Por. A.K. Kunert, Stownik biograficzny konspiracji warszawskiej 1939-1944, L 1. Warszawa 1987, ss. 88-90, także: W. Szubert, Wspomnienia o Departamencie Pracy i Opieki Spotecznej Delegatury Rzadu 1941-1944. „Przegląd Historyczny” z. 1. 1989, s. 133 i n.
} 
służyć przygotowywane w Departamencie opracowania koncepcyjne i projekty. Dotyczyło to przy tym nie tylko spraw wymagających rozstrzygnięcia w pierwszym okresie bezpośrednio po ustaniu okupacji, lecz również dalszych perspektyw rozwojowych. Podnosiło w zrozumiały sposób rangę prac prowadzonych w Departamencie i skupiało na nich szczególną uwagę władz Delegatury i czynników reprezentujących różne ośrodki społeczno-polityczne. Z tych samych względów kierunki i wyniki tych prac mogą również budzić zainteresowanie z perspektywy historycznej, w ramach badań nad rozwojem myśli społecznej, w zakresie szeroko pojętej problematyki pracy.

Istotne znaczenie miał również fakt, że Departament Pracy i Opieki Społecznej został utworzony stosunkowo wcześnie, w pierwszej połowie $1941 \mathrm{r}$., a na jego czele stanął człowiek odgrywający w życiu społeczno-politycznym okresu okupacji wybitną rolę: Jan Stanisław Jankowski, członek kierownictwa Stronnictwa Pracy, późniejszy zastępca Delegata, a następnie (od marca 1943 r.) Delegat Rządu, a więc szef wszystkich komórek organizacyjnych Delegatury. Po objęciu tego stanowiska nie przestał on nadal interesować się żywo pracami Departamentu Pracy i Opieki Społecznej oraz sprawował nad nimi nadzór. Zapewniało to ciągłość tych prac oraz wpływało na kształtowanie się ich głównych tendencji i myśli przewodnich.

Z tych względów, jak się wydaje, dorobek Departamentu utrwalony w dokumentach i w pamięci ludzkiej zasługuje na opracowanie. Takie też zamierzenie przyświeca piszącemu te słowa. Urzeczywistnieniem tego jest w pewnym stopniu niniejszy artykuł, którego kolejne części poświęcone są przedstawieniu struktury organizacyjno-personalnej Departamentu, a następnie ogólnej charakterystyce jego działalności w zakresie opieki czynnej i prac koncepcyjnych.

Kształtowanie się struktury organizacyjnej Departamentu następowało stopniowo, w miarę rozwoju jego działalności. W ciągu roku 1941 skupiała się ona przede wszystkim na prowadzeniu akcji opieki czynnej, którą organizował Jan S. Jankowski, wkładając w nią wiele osobistego zaangażowania, energii i inicjatyw $^{2}$. Prace koncepcyjne znajdowały się w tym czasie w fazie wstępnych przemyśleń i przygotowań.

Bardziej intensywny rozwój tych prac nastąpił z początkiem 1942 r., gdy w skład Departamentu wszedł, jako zastępca Jankowskiego, Stefan Mateja - wybitny prawnik, o postępowej orientacji społecznej i głębokim zaangażowaniu ideowym, bliski kręgom polskiej lewicy, w okresie okupacji współpracownik „Unii”’. Zaczęto wówczas formować zespół współpracowników Departamentu, w skład którego weszli: Jerzy Piotrowski - socjolog, uczeń Floriana Znanieckiego, wybitny znawca ubezpieczeń społecznych, w okresie okupacji związany z ruchem

\footnotetext{
2 Sprawy te znane są autorowi ze względu na osobisty kontakt w tym czasie z Janem S. Jankowskim (por. W. Szubert, Wspomnienia..., s. 139 i n.).

${ }^{3}$ Por. J. Hoppe, Wspomnienia, przyczynki, refleksje. Londyn 1972, ss. 275, 281, 299.
} 
syndykalistycznym; Maciej Święcicki - prawnik zatrudniony przed wojną w Ministerstwie Opieki Społecznej, członek „Iuventus Christiana”, w okresie okupacji związany z ośrodkiem w Laskach; Wacław Iwaszkiewicz - także przedwojenny pracownik Ministerstwa Opieki Społecznej, ekonomista, uczeń Edwarda Lipińskiego. W pracach Departamentu uczestniczył również od początku Wacław Szubert, prawnik i polityk społeczny, przedwojenny pracownik Instytutu Spraw Społecznych, w czasie wojny związany z Wydziałem Informacji BIP AK.

Członkowie tego zespołu spotkali się w ciągu 1942 r. wielokrotnie dla przedyskutowania podstawowych założeń przyszłego rozwoju polityki społecznej i prawa pracy oraz zadań wynikających stąd dla Departamentu. Na zebraniach tych, odbywanych pod przewodnictwem Stefana Matei w mieszkaniu Wacława Iwaszkiewicza (przy ul. Solec), poszczególni członkowie zespołu przedstawiali tezy dotyczące zagadnień, które były im tematycznie najbliższe. Stanowiły one punkt wyjścia do ożywionych dyskusji, z których wyłaniały się stopniowo wnioski dotyczące pożądanych rozwiązań prawno-organizacyjnych oraz następował w związku z tym tematyczny podział zadań między członków zespołu. W toku tych prac formułowane były na piśmie nie tylko tezy programowe, lecz również uwagi i propozycje, zmierzające do ich uściślenia i przedstawienia niektórych zagadnień. W zebraniach dyskusyjnych, o których mowa, uczestniczyły niekiedy, poza wymienionymi wyżej, także inne osoby. Był też na nie zapraszany prof. Edward Lipiński jako konsultant w zakresie problematyki ekonomicznej.

Dyskusje te odegrały dużą rolę w kształtowaniu wspólnego poglądu współpracowników Departamentu na pożądane kierunki przyszłego rozwoju polityki społecznej i prawa pracy oraz w konkretyzowaniu wynikających stąd zadań. Uformowane wówczas myśli znalazły później odbicie w wielu dokumentach przygotowywanych przez Departament. $\mathrm{W}$ toku tych prac ukształtowała się koleżeńska atmosfera, która wiązała odtąd podstawowy zespół pracowników Departamentu w całym okresie jego istnienia. Był to w istocie niezbyt liczny, lecz zharmonizowany ,zespół ideowo-fachowy”", składający się z ludzi stosunkowo młodych, ale o postawach ukształtowanych już w toku przedwojennej działalności i głębokich zainteresowaniach sprawami życia społecznego. Ogromną rolę w harmonizowaniu tego zespołu odegrała osobowość Stefana Matei, który był niezrównanym kierownikiem i inspiratorem zespołowych prac, wnoszącym do nich atmosferę twórczych poszukiwań i koleżeńskiego współdziałanias.

\footnotetext{
${ }^{4}$ Sprawozdanie z działalności Departamentu za okres od 1 VIII do 31 XII 1943, s. 1. Zachowało się ogółem pięć sprawozdań Departamentu za następujące okresy: X-XII 1942 (CA PZPR 202/1-32, t. 2, ss. 104-105), I-IV 1943 (ibidem 202/1-34, t. 1, s. 28), V-VII 1943 (ibidem 202/VIII, 4, s. 161), V1II-XII 1943 (ibidem 203 VII-35, t. 2, ss. 112-120), I-III 1944 (ibidem 202 1-34.1. I, ss. 66-71 oraz AAN, MPiOS Rządu Emigracyjnego RP w Londynie, sygn. 12, ss. 1-15, $309-324$, t. 1 , ss. $66-71$, ss. 3-18).

${ }^{5}$ Znaczna większość współpracowników Departamentu przed wojną była związana z Ministerstwem Opieki Społecznej i instytucjami działającymi w kręgu tego resortu (Zakład
} 
Charakter tych kontaktów utrzymał się w rozszerzonym zespole, do którego weszli z czasem: Eugeniusz Modliński - członek PPS, zajmujący już przed wojną kierownicze stanowisko w Ministerstwie Opieki Społecznej, a w czasie wojny pracujący w Ubezpieczalni Społecznej w Warszawie, oraz młodsi przedwojenni pracownicy tegoż resortu: Henryk Borkowski i Zbigniew Baucz. Ścisłą współpracę z Departamentem nawiązali również w drugiej połowie 1943 r. Marian Baran - prawnik ze Lwowa, znawca zagadnień opieki społecznej, i Marcin Kacprzak, wybitny lekarz społecznik, przedwojenny wykładowca w Państwowej Szkole Higieny i współpracownik Instytutu Spraw Społecznych w Warszawie. Koleżeńska atmosfera objęła również służby techniczne Departamentu, a w szczególności sekretariat, działający pod kierunkiem Alicji Eysmontówny ${ }^{6}$.

W miarę powiększania się zespołu pracowników Departamentu oraz rozwijania się jego działalności powstała potrzeba określenia wewnętrznych form organizacyjnych. Formy te krystalizowały się stopniowo, co miało swój wyraz w odpowiednich dokumentach, nie zawsze znajdujących pełne odbicie w układach faktycznych. W sprawozdaniu za okres od 1 VIII do 31 XII 1943 r. podano, że Departament dzieli się na pięć sekcji: ustroju i prawa pracy, zatrudnienia i płac, ubezpieczeń społecznych, zdrowia oraz opieki społecznej; prócz tego funkcjonował referat opieki czynnej, referat finansowy i sekretariat ${ }^{7}$. W kolejnym sprawozdaniu za pierwszy kwartał 1944 r. wymieniono sześć sekcji, przy czym różnica w porównaniu z poprzednim układem polegała na tym, że zakres pierwszej sekcji został ograniczony do ustroju pracy, a zakres sekcji drugiej został podzielony między dwie odrębne sekcje: zatrudnienia oraz płac i uposażeń. Zakres pozostałych sekcji nie uległ zmianie.

W sprawozdaniu tym zastrzeżono jednak, że podany schemat organizacyjny nie obejmuje wszystkich zagadnień z dziedziny polityki społecznej będących przedmiotem zainteresowania Departamentu oraz że ma charakter tymczasowy, a „dokładniejsze zarysowanie organizacji resortu polityki społecznej odracza się do czasu gruntowniejszego przemyślenia jej całokształtu”, dodano też, że „wtedy treść ułatwi znalezienie właściwej formy organizacyjnej”. Ta ostatnia uwaga miała już w istocie odniesienie do organizacji resortu pracy i opieki społecznej po

\footnotetext{
Ubezpieczeń Społecznych, Instytut Spraw Społecznych) bądź z sądownictwem pracy. Kilku z nich współpracowało z „Przeglądem Prawa Pracy” wydawanym w latach 1938-1939 przez Stowarzyszenie Przyjaciół Sądów Pracy.

${ }^{6}$ Por. W. Szubert, Wspomnienia..., s. 142 i n.; ibidem o niektórych pracownikach Departamentu (s. 146 i n.).

${ }^{7}$ Sprawozdanie z działalności Departamentu (VIII-XII 1943, s. 1).

${ }^{8}$ Ibidem (I-III 1944, s. 1). Było to ostatnie sprawozdanie przedstawione przez Departament. W czerwcu 1944 r. dyrektor Departamentu przesłał jednak do Londynu dalszą partię opracowanych dokumentów (pismo z 17 VI 1944 z załącznikami, AAN MPiOS, sygn. 12, ss. 137-142 i sygn. 179, ss. 1-2).
} 
wojnie, przy czym sugerowano zmianę jego nazwy ${ }^{9}$. Odrębnie opracowany został projekt jego statutu organizacyjnego ${ }^{10}$.

Struktura wewnętrzna Departamentu znajdowała się, jak już wspomniano, $\mathrm{w}$ stanie stopniowego kształtowania się, połączonego z pewnym formalizowaniem toku prac i łączności, obiegu dokumentów i kontaktów. Świadczy o tym treść dwóch okólników wewnętrznych Departamentu, wydanych w 1944 r. Pierwszy z nich dotyczył w szczególności sposobu przechowywania dokumentów i materiałów oraz składania wniosków w sprawie wynagrodzenia za prace zlecone. Określał on również zasady dobierania współpracowników poza osobami związanymi służbowo z Departamentem; w tym zakresie kierownicy referatów mieli znaczną swobodę (,z zachowaniem odpowiedniej ostrożności i rozwagi”). Drugi okólnik dotyczył zasad kontaktowania się z sekretariatem Departamentu, organizowania skrzynek do przekazywania wewnętrznej korespondencji i materiałów oraz organizowania obsługi w zakresie maszynopisania ${ }^{11}$.

Ten ostatni okólnik stanowi równocześnie dokument odzwierciedlający zgodną ze stanem faktycznym strukturę organizacyjną Departamentu, jaka ukształtowała się ostatecznie w przededniu powstania (czerwiec 1944 r.). Podaje on bowiem pełną listę referatów, stanowiących podstawowe komórki organizacyjne Departamentu, gdzie ogniskowały się jego prace ${ }^{12}$. Referatów tych było 11, z których 8 działało w sferze prac koncepcyjnych, związanych z przygotowywaniem rozwiązań prawno-organizacyjnych na okres powojenny.

Były to: (1) referat ogólny (kierownik Eugeniusz Modliński); do zadań tego referatu należała merytoryczna i formalna ocena dokumentów przygotowywanych przez inne referaty i zgłaszanie propozycji pod kątem ulepszenia i zharmonizowania tych dokumentów; (2) referat zatrudnienia (Wacław Iwaszkiewicz); (3) referat ustroju pracy (Maciej Święcicki w ścisłej współpracy ze Stefanem Mateją); (4) referat prawa pracy (Henryk Borkowski); (5) referat ubezpieczeń społecznych (Jerzy Piotrowski); (6) referat opieki społecznej (Marian Baran); (7) referat zdrowia (Marcin Kacprzak); (8) referat legislacyjny (Zbigniew Baucz); do zadań tego referatu należało nadawanie odpowiedniej formy projektom aktów prawnych, przygotowywanych przez Departament. Odrębny charakter miały: (9) referat opieki czynnej (Stanisław Stęplewski); (10) referat organizacyjny (Wacław Szubert, który był jednocześnie zastępcą dyrektora Departamentu); (11) referat finansowy (Marian [...], pracownik bankowy z Kielc znany osobiście Stefanowi Matei).

\footnotetext{
${ }^{9}$ Ministerstwo Spraw Społecznych.

${ }^{10}$ Statut organizacyjny Departamentu Pracy i Opieki Społecznej (był to w tym przypadku kryptonim przyszłego Ministerstwa). I Projekt (CA PZPR 203/VII-35, ss. 338-340).

${ }^{11}$ Okólnik nr 1 (bez daty), pochodzący z lutego łub marca 1944 oraz okólnik nr 2 z czerwca 1944 (zbiory rodziny Macieja Święcickiego).

${ }^{12}$ Sprawy te są znane autorowi ze względu na to, że był w tym czasie zastępcą Dyrektora Departamentu, odpowiedzialnym za wewnętrzny tok jego działalności.
} 
Odrębną komórkę organizacyjną stanowił sekretariat (kryptonim „biuro”), którym kierowała Alicja Eysmontówna („Irena”). Pracowały w nim jako łączniczki: Janina Gadomska („Wanda”), Hanna Pachnowska-Wałkówska („Ewa”) oraz jako maszynistka i łączniczka [...] („Zofia”). Na czele Departamentu stał - kierując całością jego prac - Stefan Mateja (,Żłowski”, „Rogalski”)'

To zestawienie, odzwierciedlające stan z czerwca 1944 r., informuje też o liczbie osób pozostających w ścisłym związku („etatowym”) z Departamentem. W końcu 1943 r. osób tych było dwanaście, ${ }^{14}$ a w czerwcu 1944 r. co najmniej szesnaście ${ }^{15}$. Poza tym współdziałało z Departamentem liczne grono „stałych pracowników honorowych", pozostających w bezpośrednim kontakcie ze Stefanem Mateją i kierownikami poszczególnych referatów. Pod koniec 1943 r. zespół ten liczył dwadzieścia pięć osób. Równocześnie Departament stwierdzał, że „dąży do zapewnienia sobie współpracy przede wszystkim tych, którzy są ideowo związani z zagadnieniami polityki społecznej"16. Liczba tych osób stopniowo się powiększała, trudno byłoby zatem dokładnie ustalić, ile wynosiła ona bezpośrednio przed Powstaniem, tym bardziej że kierownicy referatów mieli, jak podano wyżej, znaczną swobodę w dobieraniu współpracowników, wobec czego nie byli oni centralnie ewidencjonowani.

Dopełnieniem struktury Departamentu były komórki administracji terenowej, tworzone już w czasie okupacji, z myślą o ich rozbudowie w okresie powojennym. Na szczeblu wojewódzkim (okręgowym) były to trzy odrębne wydziały: (1) pracy, który miał stanowić w przyszłości jednostkę administracji niezespolonej, to jest podlegającą bezpośrednio resortowi pracy, (2) zdrowia i (3) opieki społecznej. Rozdzielenie tych dwóch ostatnich dziedzin nastąpiło ze względu na szeroki zakres zadań każdej z nich, związany z nasileniem potrzeb.

Tworzenie wydziałów następowało sukcesywnie, poczynając od 1942 r., a ich kierownicy byli mianowani przez dyrektora Departamentu Pracy i Opieki Społecznej, na wniosek delegatów okręgowych. Obsada tych stanowisk natrafiała na trudności, zwłaszcza na terenie województw wschodnich i do końca 1943 r. nie była jeszcze pełna; w 1944 r. trwały dalsze prace nad zorganizowaniem sieci administracji społecznej w terenie ${ }^{17}$. Zadania kierowników okręgowych wydziałów pracy oraz wydziałów opieki społecznej i lekarzy okręgowych (wojewódzkich) zostały sprecyzowane w instrukcjach opracowanych przez Departament, przy czym wyodrębniono w nich zadania przygotowawcze i zadania na moment

${ }^{13}$ Zestawienie to zostało dokonane w porządku rzeczowym. Nazwiska kierowników referatów (nie podane w okólniku) odzwierciedlają stan z połowy 1944 r. zachowany w pamięci autora.

${ }^{14}$ Sprawozdanie Departamentu VIII-XII 1943, s. 1.

${ }^{15}$ Być może należałoby tu również zaliczyć niektóre osoby, poza ówczesnymi kierownikami referatów, pozostające w bezpośredniej współpracy ze Stefanem Mateją.

${ }^{16}$ Sprawozdanie Departamentu VIII-XII 1943, s. 1.

${ }^{17}$ Por. informacje zawarte w sprawozdaniach Departamentu: X-XII 1942, s. 2, VIII-XII 1943, s. 1 i I-III 1944, s. 1. 
przełomu $^{18}$. Odrębna instrukcja dotyczyła prowadzenia w okręgach i powiatach opieki czynnej ${ }^{19}$.

Akcja opieki czynnej rozwijała się stopniowo, poczynając od pierwszej połowy $1941 \mathrm{r}$. W ciągu dwóch lat bezpośrednie kierownictwo tą akcją sprawował Jan S. Jankowski, określając jej zasady i formy. Po objęciu przez niego stanowiska Delegata Rządu centralny punkt rozdziału funduszów na cele opieki czynnej w Departamencie prowadził przez pewien czas (od połowy 1943 do początku 1944) Wacław Szubert. Następnie funkcję tę przejął Stanisław Stęplewski, co stwarzało dogodniejszą sytuację organizacyjną, ponieważ umożliwiało rozdzielnictwo funduszów konspiracyjnych pod bezpośrednią ochroną biura RGO - Rady Opiekuńczej Miejskiej, w której był on zatrudniony.

Zasady opieki czynnej, wypracowane przez Jana S. Jankowskiego, przybrały z czasem postać zorganizowanego systemu działania o szerokim zakresie i zróżnicowanych formach. Podstawowe cechy tego systemu, znane autorowi w znacznej mierze $\mathrm{z}$ autopsji, zostały wyraźnie sformułowane $\mathrm{w}$ instrukcjach dla delegatów okręgowych i powiatowych w sprawie opieki czynnej ${ }^{20} \mathrm{i}$ w sprawozdaniu z działalności Departamentu za okres 1 VIII - 31 XII 1943; na tych dokumentach opiera się też podana niżej charakterystyka.

Zakres tej akcji obejmował w szczególności dwie kategorie osób: ofiary polityczne oraz jednostki wartościowe społecznie (w obu przypadkach łącznie z członkami ich rodzin). Do pierwszej z tych kategorii zaliczano osoby dotknięte bezpośrednio terrorem lub prześladowaniem ,i to zarówno ze względów specjalnych, jak też w ramach ogólnej akcji tępienia polskości" (osoby przebywające w więzieniach i w obozach, ukrywające się przed prześladowaniami, poszkodowane ciężko na zdrowiu, objęte akcjami wysiedleńczymi itp).

Do kategorii jednostek wartościowych społecznie zaliczano natomiast osoby, „których utrzymanie przy życiu ma istotne znaczenie dla przyszłości narodu, ze względu na ich kwalifikacje zawodowe, poziom moralny i postawę obywatelską". Byli to zwłaszcza przedstawiciele świata nauki i kultury, a więc profesorowie wyższych uczelni, artyści, a także wybitniejsi działacze społeczni i inteligencja zawodowa o wyższych kwalifikacjach. Założeniem akcji opieki czynnej było jednak objęcie wybitniejszych jednostek ,ze wszystkich grup społecznych i środowisk, zarówno inteligenckich, jak i robotniczych". Szczególna uwaga była zwracana na młodzież i rodziny posiadające większą liczbę dzieci.

${ }^{18}$ CA PZPR 202/VHI, ss. 1-7 oraz 203/VII-35, t. 3, ss. 341-348a.

${ }^{19}$ Ibidem 202/VIII, ss. 8-10, 202/XXII-1, ss. 27-29 i 203/VU-35, t. 3. ss. 349-351.

${ }^{20}$ Ibidem 202/VIII, ss. 9-10 i 202/XXII-I, ss. 27-29, gdzie podano także obowiązujący schemat preliminarza i sprawozdania. 
Warunkiem udzielenia pomocy było w każdym przypadku znajdowanie się w potrzebie, to znaczy nieposiadanie ,środków wystarczających dla utrzymania się na poziomie życia, odpowiadającym (danej) grupie społecznej w warunkach wojennych". Podstawowe znaczenie miały jednak wskazane wyżej kryteria, które akcji prowadzonej przez Departament nadawały szczególny charakter, w odróżnieniu od „zwykłej opieki społecznej”. Akcja ta obejmowała osoby narodowości polskiej; mogły z niej jednak korzystać także osoby będące obywatelami państw sprzymierzonych oraz należące do mniejszości narodowych, zamieszkujących ziemie polskie, o ile wykazały się lojalnym stosunkiem do polskości. Opieka nad Żydami została zorganizowana odrębnie, w innych formach organizacyjnych ${ }^{21}$.

Pomoc świadczona była przede wszystkim w formie zapomóg pieniężnych - okresowych i jednorazowych, których maksymalna wysokość była ustalana przez Departament, a także specjalnych zapomóg dla rodzin osób przebywających w więzieniach i obozach (na paczki) ${ }^{22}$. Poza tym rozwijane były różne formy opieki pośredniej, w postaci subwencjonowania instytucji i urządzeń przeznaczonych dla osób odpowiadających wskazanym wyżej kryteriom, finansowania opieki nad więźniami, zwłaszcza dostarczania im leków i żywności, zarówno drogą legalną („do kotła”), jak i nielegalną, i inne. Nie udzielano natomiast w zasadzie pomocy finansowej na wykup z więzień czy obozów, poza wyjątkowymi przypadkami (i wówczas z reguły wykup wpłacano dopiero po wypuszczeniu więźnia lub do depozytu zaufanych osób).

Departament Pracy i Opieki Społecznej ustalał obowiązujące zasady i formy akcji opiekuńczej oraz stanowił centralny ośrodek dyspozycji i główny punkt rozdziału funduszów między różne instytucje i organizacje, legalne i nielegalne, do których należało bezpośrednie wykonawstwo. Znaczne fundusze przechodziły na tej zasadzie przez Radę Główną Opiekuńczą ${ }^{23}$, Patronat ${ }^{24}$, a także przez różne ośrodki specjalne, tworzone w porozumieniu z Departamentem do rozdziału funduszów w ustalonym zakresie. Akcja opiekuńcza sprawowana była również na zasadach określonych przez Departament i pod jego nadzorem przez inne jednostki centralne Delegatury Rządu: pomoc dla świata nauki, kultury i nauczycielstwa przez organy Departamentu Oświaty i Kultury („Pochodnia”), pomoc dla więźniów w pewnym zakresie przez komórkę więzienną Departamentu Spraw Wewnętrznych (,Sieć”).

${ }^{21}$ Rada Pomocy Żydom, której fundusze pochodziły przede wszystkim z subwencji Delegatury i organizacji społecznych. Por. M. Arczyński. W. Balcerak, Kryptonim ,Żegota”. Z dziejów pomocy Żydom w Polsce (1939-1945). Warszawa 1979.

${ }^{22} \mathrm{~W}$ wymienionych wyżej dokumentach określono wymiar zapomóg okresowych i jednorazowych stosownie do sytuacji i charakteru potrzeb.

${ }^{23}$ Fundusze te przekraczały w niektórych zakresach znacznie środki, jakimi dysponowała RGO legalnie. Por. B. Kroił, Rada Gtówna Opiekuńcza 1939-1945. Warszawa 1985, ss. 134-135.

${ }^{24}$ Por. Z. Zbyszewska, Ministerstwo Polskiej Biedy. Warszawa 1983, ss. 88-89. 
Fundusze przeznaczone na cele opieki czynnej poza Warszawą rozprowadzane były przede wszystkim przez okręgi Delegatury. Obowiązkiem kierowników wydziałów opieki w okręgach było zorganizowanie sieci rozdziału rozporządzalnych środków, obejmującej wszystkie większe skupiska ludności polskiej oraz wszystkie więzienia i obozy znajdujące się na terenie okręgu, a także nawiązanie ścisłego kontaktu ze wszystkimi instytucjami działającymi na tym terenie w zakresie opieki społecznej legalnie i nielegalnie. Kierownicy okręgowych wydziałów opieki mieli również współdziałać z lokalnymi komórkami Departamentu Oświaty i Kultury, czemu służyło zapewnienie udziału ich przedstawicieli w podejmujących decyzje o przyznaniu pomocy komisjach kwalifikacyjnych tworzonych przez te komórki.

Organizowanie opieki bezpośrednio w terenie należało do delegatów powiatowych, których zadaniem było stworzenie w powiatach sieci punktów opieki czynnej w celu rejestrowania osób potrzebujących pomocy, przeprowadzania wywiadu społecznego w celu zbadania ich sytuacji życiowej oraz dokonywania na tej podstawie rozdziału posiadanych środków. Rolę takich punktów mogły pełnić miejscowe placówki legalnej opieki społecznej bądź organizacje nielegalne albo indywidualnie zaufane osoby ${ }^{25}$.

Rozdział funduszów pomiędzy poszczególne instytucje prowadzące akcję opieki czynnej i okręgi Delegatury był dokonywany na podstawie przedstawianych przez nie preliminarzy, podlegających zatwierdzaniu przez Departament; obowiązkiem ich było również składanie periodycznych sprawozdań (co dwa miesiące ${ }^{26}$. Przedstawianie preliminarzy i sprawozdań obowiązywało również odpowiednio delegatów powiatowych, z tym że należało dążyć do prowadzenia opieki czynnej w powiatach bez kosztów administracyjno-osobowych. Ustanowienie etatu powiatowego referenta opieki czynnej wymagało zgody delegata okręgowego. W ten sposób całokształt akcji opiekuńczej był koordynowany przez Departament i jego komórki terenowe (w okręgach). Instytucje i ośrodki opieki czynnej działające na terenie Warszawy były zasilane funduszami bezpośrednio przez Departament i tutaj jednak pewien zakres akcji opiekuńczej był organizowany w ścisłym porozumieniu z Departamentem przez miejscowego delegata.

Akcja opiekuńcza oparta na przedstawionych powyżej zasadach obejmowała wszystkie ziemie wchodzące w roku 1939 w skład Rzeczypospolitej Polskiej. Rozwinęła się jednak najpełniej na terenie tzw. Generalnego Gubernatorstwa. Na pozostałych ziemiach (zachodnich i wschodnich) była połączona z większymi

${ }^{25}$ Instrukcja dla delegatów powiatowych w sprawie opieki czynnej (CA PZPR 202;VIII, s. 8).

${ }^{26} \mathrm{~W}$ aktach okręgu krakowskiego Delegatury Rządu zachowało sie sprawozdanie z akcji pomocy (bez daty) dotyczące, jak wynika z jego treści, okresu IX-X 1944. Obejmuje ono m.in. opiekę nad „ofiarami terroru narodowościowego - uchodźcami ze Wschodu (Wołyń i Galicja Wschodnia)". Brak w nim natomiast jeszcze danych o pomocy dla wysiedleńców z Warszawy (CA PZPR 202 XXII-3, ss. 22-23). 
trudnościami, ze względu na słabszą obsadę personalną komórek terenowych Delegatury, brak legalnych instytucji opiekuńczych, bardziej złożoną sytuację ludności polskiej. Dokładano jednak dużych starań, aby docierała szerszym strumieniem także i na tamte tereny.

Zakres akcji opieki czynnej rozszerzał się stale. W sprawozdaniu za okres 1 VIII - 31 XII 1943 podano, że jej budżet miesięczny wzrósł w czasie od $1 \mathrm{~V}$ do 30 X 1943 o 100\%. Znacznie wymowniejsze jest zestawienie środków przeznaczonych na rzecz Departamentu w preliminarzach budżetowych Delegatury. W 1943 r. środki te wyrażały się kwotą 1213800 dolarów (co stanowiło 28\% całego budżetu), a w preliminarzu roku 1944 wzrosły do 4672600 dolarów (39\% budżetu $)^{27}$.

Akcja opiekuńcza o przedstawionym wyżej charakterze stanowiła odrębny, ważny nurt działalności Departamentu, obok rozwijających się w spokojniejszym rytmie prac koncepcyjnych i programowych. Angażowała ona silnie nie tylko referat opieki czynnej, lecz także kierownictwo Departamentu, jego sekretariat i służbę łączności oraz w szczególny sposób referat finansowy. Wymagała licznych kontaktów z ludźmi biorącymi udział w tej akcji i stwarzała szczególną atmosferę ideową, wynikającą ze świadomości działania na rzecz szczególnie ważnych i bolesnych potrzeb. Atmosfera ta towarzyszyła zwłaszcza akcji na rzecz Patronatu $^{28}$ oraz akcji „RR”, polegającej na organizowaniu pomocy finansowej dla rodzin osób rozstrzelanych w masowych egzekucjach, obwieszczanych publicznie w formie znanych dobrze warszawiakom plakatów rozwieszanych na mieście ${ }^{29}$.

\section{III}

Równolegle rozwijały się prace koncepcyjno-programowe Departamentu, zorientowane ku przyszłości: tej bliższej, bezpośrednio powojennej i dalszej, w której będą się już kształtowały na nowych zasadach trwalsze formy narodowego bytu. Założenia tych prac, prowadzonych w zakresie polityki społecznej i prawa pracy „Z myślą o planowaniu nowego świata” ${ }^{30}$, wynikały bezpośred-

${ }^{27}$ Por. E. Duraczyński, Polski Rząd na emigracji i jego krajowa delegatura, [w:] Wojna i okupacja na ziemiach polskich 1939-1945. W. Góra (red.). Warszawa 1985, s. 331, a także dane przytoczone przez W. Grabowskiego, Delegatura Rząu na Kraj (1941-1944). Zarys struktury organizacyjnej. Kraków 1987 (maszynopis, s. 27).

${ }^{28} \mathrm{Z}$ ramienia Patronatu kontaktowała się z Departamentem Irena Nowodworska.

${ }^{29}$ Akcję tę, zorganizowaną w powiązaniu ze Społeczną Organizacją Samoobrony (SOS), prowadziła na terenie Warszawy i znacznej części GG, z udziałem członkiń grupy wykonawczej Szarych Szeregów i wykorzystując kontakty z legalnymi ośrodkami opieki społecznej Maria Chełmicka („Horpyna”). Wzmianka o niej, bez podania nazwiska, zob.: E. Manteufflowa, Praca społeczna wśród rodzin. „Opiekun Społeczny” nr 1-2. 1946, s. 44.

${ }^{30}$ S. Ossowski, Ku nowym formom życia spolecznego. Warszawa 1947, s. 13. Broszura ta została wydana poprzednio konspiracyjnie pt. Najogólniejsze postulaty nowoczesnej demokracji. 
nio z analizy sytuacji społeczno-gospodarczej kraju w okresie dwudziestolecia międzywojennego oraz skutków okupacji.

Pierwszy z tych wątków sprowadzał się do uświadomienia sobie podstawowych faktów charakteryzujących sytuację i rozwój społeczno-gospodarczy ówczesnej Polski. Fakty te, dokumentowane w latach trzydziestych przez instytucje badawcze wyspecjalizowane $\mathrm{w}$ tym przedmiocie ${ }^{31}$, składały się na obraz głęboko przejmujący. Zacofanie gospodarcze kraju, słabe uprzemysłowienie, upośledzenie społeczno-gospodarcze wsi, masowe bezrobocie i swoiste dla stosunków wiejskich zjawisko zbędności licznych rzesz ludności rolniczej - produkcyjnie nie wykorzystanej, słabość organizacyjna świata pracy, do której przyczyniało się również rozbicie związków zawodowych, i wreszcie rażące nierówności społeczne i niesprawiedliwe linie podziału - oto niepełny jeszcze obraz ówczesnych zjawisk, które musiały budzić głęboki niepokój o przyszłość kraju, borykającego się z tak poważnymi obciążeniami, hamującymi jego rozwój. Nie chodziło tu o sąd nad dwudziestoleciem, ani o zaprzeczanie wielu ówczesnych osiągnięć, ale o inwentaryzację podstawowych faktów, obrazujących bilans społeczno-gospodarczy kraju, czy raczej jego stan w końcowych latach okresu międzywojennego.

Były to fakty o wymowie niedwuznacznej, których uświadomienie musiało pobudzać do poszukiwania dróg wyjścia na przyszłość oraz środków działania umożliwiających dokonanie zasadniczych zmian, przeobrażających oblicze społeczno-gospodarcze kraju oraz wzmacniających jego potencjał. Odczucie i głębokie zrozumienie tej potrzeby leżało u podstaw wszelkich prac koncepcyjnych Departamentu, kreślących drogi przyszłej przebudowy.

Drugi element wstępnego bilansu: realia okresu okupacji, przedstawiał obraz przerażający, jakkolwiek było jeszcze za wcześnie na podsumowywanie całości doznanych klęsk i strat. Wyniszczenie biologiczne i pauperyzacja szerokich rzesz społeczeństwa, hekatomba krwawych ofiar, ogrom zniszczeń materialnych, zerwanie więzi społecznych na skutek masowych przesiedleń ludności, unicestwienie wielu instytucji o kluczowym znaczeniu dla normalnego życia kraju ${ }^{32}$ - wszystko to wskazywało, że po wojnie start do niepodległego bytu będzie się odbywał w sytuacji dramatycznie zaostrzonej, wśród wielu zagrożeń.

Bardziej złożony obraz przedstawiały ukształtowane pod wpływem realiów okupacji przemiany w sferze moralności społecznej. Obok demoralizacji, której ulegały żywioły słabsze, w szerokich kręgach społeczeństwa występowały zjawiska głęboko pozytywne: wielka mobilizacja sił moralnych, gotowość do poświęceń

Zagadnienia demokratycznej organizacji życia zbiorowego (dwie części w jednej broszurze), Warszawa 1943.

${ }^{31}$ Zwłaszcza przez Instytut Gospodarstwa Społecznego i Instytut Spraw Społecznych. Szczególne znaczenie miały książki: Bezrobocie wśród chłopów (Warszawa 1939) i Młodzież sięga po prace (Warszawa 1938).

32 Bliższą orientację w tych realiach zapewniała Departamentowi współpraca z Wydziałem Informacji BIP AK oraz akcja opieki czynnej. 
dla wspólnej sprawy, ofiarność. Umacniało się poczucie solidarności narodowej w obliczu represji zagrażających wszystkim warstwom społecznym. $Z$ tymi wartościami można było łączyć nadzieje na kształtowanie się pozytywnych postaw z chwilą uwolnienia kraju od okupanta: na wzmożony wysiłek pracy w celu dźwignięcia kraju z ruin, na szeroką mobilizację sił społecznych w budowie zrębów życia nowego, wolnego od koszmarów okupacyjnej „nocy i mgły”, na gotowość przechodzenia do porządku nad konfliktami interesów, w imię wspólnego dobra. Przewidywania te nie pozostały bez wpływu na proponowane przez Departament kierunki działań, zwłaszcza w okresie bezpośrednio powojennym. Wydawało się, że w tym okresie, wobec ogromu pracy do wykonania i przerzedzonych bardzo szeregów ludzkich, zapewnienie zatrudnienia wszystkim zdolnym do pracy nie powinno stwarzać poważniejszych trudności.

Rozważenie tych wszystkich aspektów sprawy prowadziło nieodmiennie do wniosku, że wśród bezmiaru zniszczeń i strat - bardziej niż w jakiejkolwiek innej sytuacji - podstawową wartością będzie praca i że w tej dziedzinie będą leżały główne przesłanki działania zmierzającego do gospodarczego podźwignięcia kraju i zapewnienia mu dalszego rozwoju. Kluczowego znaczenia nabierała z tej perspektywy wielka mobilizacja szerokich rzesz ludzkich do pracy wydajnej i twórczej, dobrze zorganizowanej i sprawiedliwie, choć na początku skromnie wynagradzanej, a także cenionej społecznie i zapewniającej odpowiednią pozycję w społeczeństwie. Uświadomienie sobie tego faktu podnosiło rangę zadań stojących przed Departamentem i nakładało nań szczególne obowiązki w planowaniu działań, służących powyższemu celowi. Istotna jego treść sprowadzała się do stwarzania przesłanek dla pobudzania i umacniania woli pracy, czemu powinny służyć rozwiązania prawno-polityczne i instytucjonalne stwarzające odpowiedni klimat społeczny i motywację.

Działania, o których mowa, należało planować w dwóch cyklach: pierwszym, bezpośrednio powojennym (który określano jako „przejściowy” zakładając, że potrwa on kilka lat), oraz drugim, gdy zarysuje się już pewna normalizacja ogólnej sytuacji, jakkolwiek skutki wojny i okupacji będą nadal boleśnie odczuwane. W pierwszym z tych okresów należało dążyć przede wszystkim do opanowania żywiołowych procesów związanych z masowymi przemieszczeniami ludności oraz zaspokojenia, choćby w najskromniejszym zakresie, ogromu elementarnych potrzeb. Należało też przygotować podstawy prawno-organizacyjne do podjęcia działalności przez administrację pracy, ubezpieczenia społeczne, służbę zdrowia, instytucje pomocy i opieki społecznej. Działania doraźne tego okresu powinny przy tym torować drogę rozwiązaniom trwalszym, zgodnym z założeniami programowymi Departamentu na dalszą przyszłość.

$\mathrm{W}$ tej perspektywie jako główne zadanie zarysowało się nie tylko podźwignięcie kraju ze zniszczeń wojennych, lecz także przezwyciężenie jego społeczno-gospodarczego zacofania. Zakładało to potrzebę wprzęgnięcia wszystkich możliwych do rozporządzenia sił i środków do wielkiego wysiłku 
inwestycyjno-produkcyjnego, połączonego z koniecznością pewnych wyrzeczeń w zakresie zaspokajania bieżących potrzeb. Do urzeczywistnienia tych zadań wydawało się z kolei niezbędne dokonanie zmian ustrojowych, które mogłyby wyzwolić nowe źródła energii społecznej oraz zapewnić odpowiednie ich spożytkowanie oraz ciągłość działania w dążeniu do urzeczywistnienia założonych celów.

Istniejący do 1939 r. system gospodarczy w sposób oczywisty nie dawał takich możliwości. Zarysowała się zatem potrzeba głębszych przeobrażeń, umożliwiających koncentrację sił i środków w dążeniu do racjonalizacji i humanizacji oraz pobudzenia dynamiki życia gospodarczego. Wynikał stąd postulat wprowadzenia gospodarki planowej, który już przed wojną miał u nas wielu zwolenników $^{33}$, a w czasie wojny uzyskał szerokie prawo obywatelstwa ${ }^{34}$. Jego afirmacja nie oznaczała jednak zgodności stanowisk co do konkretnych rozwiązań.

Przyjętą przez Departament koncepcję gospodarki planowej cechowało ograniczenie bezpośredniego władztwa i zarządu państwowego oraz położenie nacisku na społeczne mechanizmy planowania. Zakładano, że uspołecznieniu podlegałby przemysł kluczowy, natomiast własność środków produkcji w tym zakresie, w jakim pozostawałaby w rękach prywatnych, miała być poddana kontroli sposobu jej użytkowania i rozmiaru ciągniętych z niej zysków poprzez stosowanie odpowiedniej polityki finansowej, kredytowej i podatkowej. Dzięki czemu własność ta miała nabrać charakteru funkcji społecznej wykonywanej w interesie ogółu.

Dokonanie tych przemian zakładało istnienie władzy posiadającej odpowiedni autorytet w społeczeństwie oraz wzmożenie dyscypliny społecznej, nie powinno jednak prowadzić do omnipotencji aparatu państwowego. Uważano bowiem, że osiągnięcie postulowanego wysiłku produkcyjnego będzie możliwe jedynie w razie powiązania rozwoju gospodarczego z postępem społecznym, który powinien polegać nie tylko na zapewnieniu ludziom pracy zatrudnienia i odpowiedniego, stopniowo podnoszonego poziomu egzystencji, ale również na dopuszczeniu ich do udziału w kierowaniu życiem produkcyjnym, a przez to nadaniu im prawa „obywatelstwa społeczności gospodarczej”35. Uważano za niezbędne powoła-

${ }^{33}$ O. Lange, Droga do socjalistycznej gospodarki planowej (1934). Istota Socjalizmu (1938). Gospodarcze podstawy demokracji w Polsce (1943), [w:] Wizje gospodarki socjalistycznej. Warszawa 1985, ss. 141, 253, 316. W publikacjach tych Lange postulował uspołecznienie, a nie upaństwowienie gospodarki, oddzielenie gospodarki od polityki, rozbudowę samorządu gospodarczego. Przeciwdziałanie biurokratyzacji. Por. także: K. Krzeczkowski, Idee przewodnie ubezpieczeń społecznych. Warszawa 1936, s. 183 oraz Młodzież sięga po pracę, s. V.

${ }^{34}$ Znalazło to wyraz w deklaracji Rady Jedności Narodowej: O co walczy naród polski? „Rzeczpospolita Polska”, numer specjalny, marzec 1944, s. 3. Rozdział tej deklaracji pt. Polityka społeczna zawiera myśli odpowiadające koncepcjom programowym Departamentu. Za gospodarką planową opowiada się S. Ossowski (op. cit., ss. 38-47). Zwracając jednak uwagę na związane z nią niebezpieczeństwa oraz postulując „uspołecznienie, które nie sprowadza się do upaństwowienia”.

${ }^{35}$ Notatka pt. Myśli o S.S.G. (samorządzie społeczno-gospodarczym) w materiałach Departamentu, s. 2 (zbiory autora). 
nie w tym celu samorządu społeczno-gospodarczego przy odpowiednim udziale czynnika pracy z szerokimi uprawnieniami w zakresie inicjatywy i wykonywania zadań gospodarczych.

W tej koncepcji, nawiązującej do nie urzeczywistnionych w pełni postanowień Konstytucji marcowej z 1921 r, struktura samorządu społeczno-gospodarczego miała być dopełniona przez utworzenie izb pracy ${ }^{36}$, dla których organizacyjną podstawę miał stanowić ruch zawodowy. Samorząd ten był pomyślany w całości jako ,pośrednie wiązadło pomiędzy jednostką a państwem”, umożliwiające harmonizowanie ,przeciwstawnych czynników swobody i podporządkowania" oraz pobudzanie rozwoju inicjatywy indywidualnej i grupowej w ramach struktur wyposażonych w pewną autonomię ${ }^{37}$.

Organizacyjną podstawą samorządu pracy mogły jednak być tylko silne związki zawodowe, tworzące odpowiednio reprezentatywne struktury. Należało tym samym zapobiec rozbiciu ruchu zawodowego pomiędzy nazbyt liczne słabe organizacje i zrzeszenia, nie mające realnej możliwości działania w obronie interesów pracowniczych. Celowi temu powinna służyć między innymi regulacja prawna stawiająca określone wymagania co do liczebności członków i zakresu działania tworzonych organizacji związkowych. W tym też kierunku zmierzały projekty przygotowane przez Departament, poszukujące optymalnych rozwiązań w tej delikatnej materii. Zakładano, że konsolidacja ruchu zawodowego nie będzie wyłączała istnienia i równoległego działania związków zrzeszonych w różnych centralach reprezentujących podstawowe kierunki ideologiczne tego ruchu.

Odrębny charakter miały w koncepcji Departamentu rady zakładowe, pomyślane jako instytucje organizujące współdziałanie społeczności zakładów pracy w dążeniu do osiągania wspólnych celów. Rady te miały zapewnić pracownikom udział w rozstrzyganiu spraw interesujących ich wspólnie, kładąc tym samym „kres samowładztwu”38 kierownika i przekształcając wydawany przez niego regulamin pracy w uchwalaną przez rady „konstytucję zakładową" ${ }^{39}$ normującą wewnętrzne życie zakładów pracy. Bliższe określenie uprawnień rad zakładowych, a zwłaszcza spraw, co do których miałyby one głos decydujący, było kwestią kontrowersyjną ${ }^{40}$. W uzgodnionych ostatecznie tekstach uprawnienia te dotyczyły raczej spraw pracowniczych i socjalnych aniżeli techniczno-produkcyjnych, z tym że przewidywano możliwość rozszerzenia tych uprawnień, a w spółkach akcyjnych rada miała uczestniczyć w wykonywaniu społecznej kontroli spółki (przez przedstawicieli zasiadających $\mathrm{w}$ walnych zgromadzeniach akcjonariuszy).

\footnotetext{
${ }^{36}$ Postulaty utworzenia izb pracy były formułowane przed wojną. Por.: W. Landau, Izby Pracy. Warszawa 1932; M. Święcicki, Instytucje polskiego prawa pracy 1918-1939. Warszawa 1960, s. $318 \mathrm{in}$.

${ }^{37}$ Myśli o S.S.G. (por. wyżej przypis 35), s. 1.

${ }^{38}$ Notatka pt. Ustrój pracy w materiałach Departamentu, s. 1 (zbiory autora).

${ }^{39}$ Ibidem, s. 2.

${ }^{40}$ Por. A. Bień, Bóg jest wyżej, dom jest dalej. „Przedświt”. Warszawa (b.r.), s. 71 i 101.
} 
Syntetyczny obraz przedstawionych wyżej koncepcji stanowiła idea „ustroju opartego na pracy" "41 , której w Departamencie nadawano szerokie znaczenie, wiążąc z nią szereg ważnych przemian zmierzających do umocnienia pozycji świata pracy jako współgospodarza w państwie, a także do należytego zorganizowania i wartościowania pracy ludzkiej i sprawiedliwego ukształtowania towarzyszących jej stosunków społecznych.

Celowi temu powinno służyć urzeczywistnienie prawa do pracy w ramach planowej polityki zatrudnienia zakładającej aktywną rolę jej organów. Prawo to miałoby być skorelowane z obowiązkiem pracy wyrażającym moralną powinność pracy dla wspólnego dobra i nie powinno wynaturzać się w zagwarantowanie podstaw egzystencji ,przy pomocy najmniejszego wysiłku"42.

Z tych samych założeń ideowych wynikał postulat podniesienia pracy do roli podstawowego wyznacznika pozycji społecznej człowieka, co wymagało stworzenia nowej hierarchii społecznej, w której główne kryterium stratyfikacji stanowiłyby „rodzaj i jakość spełnianej pracy”, ocenianej według „ważności jej efektów dla wspólnoty narodowej"43. Kryterium to miało stać się powszechnie obowiązującym w miejsce innych, określanych jako „klasowe”, a więc opartych na urodzeniu, przynależności do uprzywilejowanych kręgów społecznych czy na posiadanym majątku. Płynął stąd ważny wniosek dotyczący miejsca wyznaczanego inteligencji, która miała być poddana ogólnym kryteriom wartościowania według pracy i afirmowana stosownie do posiadanych kwalifikacji i sposobu ich spożytkowania. Predestynowało to ją do roli kierowniczej, ale nie do pozycji uprzywilejowanej poza powyższymi kryteriami i odrębnego statusu prawnego.

$\mathrm{Z}$ zajmowaną pozycją $\mathrm{w}$ hierarchii społecznej powinna wiązać się sytuacja materialna i całokształt wyznaczających ją uprawnień: w zakresie wynagrodzenia za pracę i różnych świadczeń, urlopów wypoczynkowych itd. Wynikał stąd postulat odpowiedniego uregulowania stosunków pracy oraz ich uniezależnienia od zmiennych sytuacji rynkowych i swoistego targu upodobniającego pracę ludzką do towaru. Celowi temu miałaby służyć ,instytucjonalizacja pracy"44 gwarantująca pracownikom stabilizację ich pozycji społeczno-prawnej, przez unormowanie ich statusu na podstawie obiektywnych kryteriów, odpowiadających właściwej ocenie społecznej wartości wykonywanych zadań. Chodziło przy tym nie tylko o aspekt ściśle prawny takiej regulacji, ale i o aspekt społeczno-moralny: uwydatnienie roli pracy jako funkcji pełnionej na zasadach określonych przez społeczeństwo.

\footnotetext{
${ }^{41}$ Notatka bez tytułu przedstawiająca idee przewodnie polityki społecznej (taki zapis odręczny na odwrocie) w materiałach Departamentu, s. 3 (zbiory autora).

42 „Notatka o planowaniu społecznym i gospodarczym” w materiałach Departamentu, s. 3 (zbiory autora).

${ }^{43}$ Notatka Idee przewodnie... (por. przypis 41 ), teza $18 \mathrm{c}$.

${ }^{44}$ Ibidem, tezy 4 i 5.
} 
Całość koncepcji programowych Departamentu wiązała się z określeniem charakteru i zadań polityki społecznej. W obliczu postulowanych przemian polityka ta miała uzyskać nowy wymiar. Nie mogłaby już nadal ograniczać się do „łagodzenia szkodliwych objawów życia społecznego" i wiązanych z tym napięć społecznych ${ }^{45}$, innymi słowy nie mogłaby być nadal polityką wyłącznie ochronną. Powinna rozwinąc szeroki zakres działań konstruktywnych, włączając się aktywnie do budowy nowego porządku społecznego: ustroju opartego na pracy, odpowiednio do przedstawionych wyżej zasad. Wynikała stąd potrzeba nowego określenia wzajemnego stosunku polityki społecznej i polityki gospodarczej, polegającego na podziale zadań w ramach wspólnoty celów ogólnych ${ }^{46}$.

Pozytywne oddziaływanie polityki społecznej miałoby zmierzać przede wszystkim do potęgowania woli pracy w społeczeństwie, do intensyfikacji szkolenia zawodowego i podnoszenia jakości pracy oraz do planowego kierowania procesami zachodzącymi na rynku pracy i migracjami wewnętrznymi ${ }^{47}$. Szersze rozwinięcie tych zadań znalazło wyraz w pracach koncepcyjnych Departamentu dotyczących różnych zakresów polityki społecznej i ustawodawstwa społecznego. Prace te dotyczyły między innymi administracji i pośrednictwa pracy, zatrudnienia młodzieży i powszechnego obowiązku nauki zawodu, szczególnego trybu powoływania do pracy w okresie przejściowym przez organizacje zawodowe i inne. Równolegle opracowywane były podstawy prawne polityki plac, która w okresie przejściowym miała zmierzać do stopniowej odbudowy wartości realnej, zwłaszcza najniższych wynagrodzeń, i do załatwiania spraw konfliktowych poprzez procedury rozjemcze. Przygotowywano również trwalsze podstawy prawne pojednawstwa i rozjemstwa w zatargach zbiorowych oraz nową ustawę o układach zbiorowych pracy.

W zakresie indywidualnego prawa pracy koncepcje Departamentu zmierzały natomiast do urzeczywistnienia ,jedności pracowniczej”, to jest do przezwyciężenia separatyzmów oddzielających służbę publiczną od umownych stosunków pracy oraz pracowników umysłowych od robotników. Wszystkie te stosunki powinny być, zdaniem Departamentu, unormowane w jednej ustawie, która miała przygotować grunt dla przyszłej kodyfikacji prawa pracy.

Znaczny stopień konkretności osiągnęły prace programowe $\mathrm{w}$ dziedzinie ubezpieczenia społecznego, dotyczące nie tylko uporządkowania stanu prawnego w okresie przejściowym, ale i trwalszych zmian na przyszłość. Miały one polegać na objęciu ubezpieczeniami ogółu pracowników oraz na zniesieniu nieuzasadnionego zróżnicowania ich uprawnień upośledzającego robotników w stosunku do pracowników umysłowych. W dalszej perspektywie przewidywano rozciągnięcie zakresu ubezpieczeń społecznych na grupy pozapracownicze (rzemieślnicy,

\footnotetext{
${ }^{45}$ Sprawozdanie Departamentu I-I 11.1944, s. 1.

${ }^{46}$ Notatka Idee przewodnie..., teza 19.

${ }^{47}$ Ibidem, teza 14.
} 
rolnicy). Postulowano odbudowę samorządu ubezpieczeniowego o szerokich uprawnieniach o charakterze stanowiącym i kontrolnym. Dopełnieniem powszechnego systemu ubezpieczeń społecznych miały być ubezpieczenia dodatkowe, będące wyrazem przezorności zbiorowej. Opracowano koncepcję uzdrowienia podstaw finansowych ubezpieczeń, które w wyniku wojny uległy praktycznie unicestwieniu.

Lecznictwo ubezpieczeniowe miało stać się bazą stopniowej rozbudowy powszechnej służby zdrowia obejmującej całą ludność. W związku z tym organizacja służby zdrowia miała być ujednolicona na terenie całego kraju, obejmując sieć odpowiednio rozmieszczonych i wyspecjalizowanych szpitali oraz ośrodków zdrowia. W koncepcji Departamentu poważną rolę miał do odegrania samorząd zawodowy (izby lekarskie).

Przedmiotem prac Departamentu było również zorganizowanie na nowych zasadach opieki społecznej, przed którą stawały ogromne zadania, zwłaszcza w okresie przejściowym. Przewidywano znaczną rozbudowę działalności opiekuńczej w celu zaspokojenia najsilniejszych potrzeb, przede wszystkim opieki nad matką i dzieckiem, a bezpośrednio po wojnie - opieki nad ludnością powracającą do kraju i przesiedleńcami. Przewidywano, że opieka społeczna sprawowana przez gminy zostanie uzupełniona przez działalność opiekuńczą organizacji społecznych, w szczególności przez Polski Komitet Samopomocy Społecznej, który miał powstać na miejsce Rady Głównej Opiekuńczej.

Koncepcje Departamentu we wszystkich powyższych zakresach formułowane były najpierw w postaci tez, podlegających dyskusji wewnętrznej, bądź także na forum Komitetu Ekonomicznego Delegatury Rządu i jego komisji ${ }^{48}$. Dalszą fazą było przygotowywanie projektów aktów prawnych wraz z uzasadnieniami, a w pewnych przypadkach również przepisów wykonawczych. W toku tych prac powstawały - jako produkt uboczny - notatki poświęcone opracowaniu różnych nasuwających się problemów.

Najbardziej dojrzały owoc prac Departamentu stanowił dekret o radach zakładowych, który po zaakceptowaniu przez centralne komórki Delegatury doczekał się urzędowej publikacji w czasie powstania warszawskiego ${ }^{49}$. Opracowano również wiele innych projektów aktów prawnych, dotyczących: związków zawodowych, izb pracy, ubezpieczeń społecznych, różnych aspektów polityki

${ }^{48}$ M.in. w komisji cen i plac, w komisji uprzemysłowienia oraz w komisji rynku pracy, w której przewodniczącym był dyrektor Departamentu (sprawozdanie Departamentu X-XII 1942). Koncepcje dotyczące ustroju pracy były ponadto konsultowane z przedstawicielami związków zawodowych: klasowych i chrześcijańskich (sprawozdanie Departamentu I-III 1944, s. 2).

${ }^{49}$ Rozporządzenie Krajowej Rady Ministrów z 1 VIII 1944 r. o radach zakładowych (,Dziennik Ustaw RP”. cz. III. Warszawa, 2 VIII 1944. nr 2 poz. 16). Treść tego aktu została omówiona przeze mnie w artykule: Rady Zakładowe. „Rzeczpospolita Polska” nr 38 (i 10) z 27 VIII 1944; także opracowanie analityczne: W. Szubert, Rady Zakładowe w świetle aktu prawnego z dnia 1 sierpnia 1944. „Czasopismo Prawno-Historyczne” 1990 (w druku). 
zatrudnienia i płac itd. Niektóre $\mathrm{z}$ nich zostały przygotowane $\mathrm{w}$ formie wykończonej lub bliskiej wykończenia (niekiedy w paru wersjach), inne miały jeszcze charakter roboczy. Istotną część dorobku Departamentu stanowiły również opracowania tezowe, zwłaszcza dotyczące zagadnień społeczno-gospodarczych ${ }^{50}$.

Pracom, o których mowa, towarzyszyły trudności wynikające między innymi ze ścierania się różnych poglądów i stanowisk w łonie Delegatury. Wiele przyczyn złożyło się na nierówny poziom poszczególnych opracowań i na to, że przedstawione $\mathrm{w}$ nich propozycje są $\mathrm{w}$ różnym stopniu przekonywające. Ocena tego obfitego materiału przechowywanego $\mathrm{w} \operatorname{archiwach}^{51} \mathrm{i} \mathrm{w}$ zbiorach prywatnych musiałaby w związku z tym wypaść niejednolicie. $\mathrm{Z}$ czasem ujawnią to zapewne opracowania analityczne dotyczące różnych instytucji i dziedzin objętych zakresem prac koncepcyjnych Departamentu, wydobędą również braki polegające na niedostatecznym skonkretyzowaniu niektórych koncepcji czy też pominięciu pewnych aspektów.

Nie antycypując tych sądów (byłyby one nie na miejscu w artykule informującym o pracach, w których autor sam uczestniczył), należałoby zauważyć, że koncepcje Departamentu nie kształtowały się w próżni. Oddziałały na nie sądy i myśli programowe zrodzone w środowisku przedwojennego Instytutu Gospodarstwa Społecznego i Instytutu Spraw Społecznych, a także w postępowych kręgach pracowników Ministerstwa Opieki Społecznej, Zakładu Ubezpieczeń Społecznych i sądownictwa pracy, współdziałających zwłaszcza z tym drugim Instytutem.

Przyjęta przez Departament koncepcja gospodarki planowej o społecznych treściach, opartej na strukturach samorządowych, miała w polskiej myśli społecznej wielu wybitnych przedstawicieli ${ }^{52}$. Źródłem niewątpliwych wpływów były opracowania programowe Polskiej Partii Socjalistycznej ${ }^{53}$ i Stronnictwa Pracy, a w szczególności myśli nurtujące środowisko okupacyjnej „Unii” ${ }^{4}$, w której pracach uczestniczył dyrektor Departamentu Stefan Mateja.

Żywy oddźwięk w zespole pracowników Departamentu budziły idee syndykalistyczne, wywodzące się od Sorela i rozwijane przez jego polskich kontynu-

${ }^{50}$ Por. A. Bień, op. cit., ss. 71 i 101.

${ }^{51}$ Głównie w CA KC PZPR, zespoły akt „Delegatura Rządu” i Armia Krajowa** oraz w AAN, zespół akt: Ministerstwo Pracy i Opieki Społecznej Rządu Emigracyjnego w Londynie.

${ }_{52}^{5}$ Por. wyżej przypisy 33 i 34.

${ }^{53}$ Por. J. Tomicki, Polska Partia Socjalistyczna 1892-1948. Warszawa 1983, ss. 339-340, 377, 419. Por. także: A. Kriszke, O kształt Niepodległej. Warszawa 1989. s. 433 i n.

${ }^{54} \mathrm{~W}$ szczególności koncepcje J. Hoppego w kwestii uspołecznienia państwa, roli samorządu społeczno-gospodarczego, izb pracy i in. Por. J. Hoppe, Wspomnienia..., ss. 65, 76-78, 94. Koncepcje te kształtowały się już przed wojną w grupie: ,Jutro Pracy”. Por. tegoż autora, Samorząd pracy (Warszawa 1932), a także Tezy w sprawie aktualnych zagadnień dotyczacych świata pracy - uchwalone przez Parlamentarna Grupe Pracy (1936), których autorem był Z. Madeyski. Por. także: W. Bujak, Historia Stronnictwa Pracy 1937-1946-1950. Warszawa 1988, ss. 114-115; A. Friszke, Wizja przyszłego państwa w koncepcjach czterech stronnictw obozu rządowego w kraju 1939-1944, [w:] Państwo w polskiej myśli politycznej. Ossolineum 1988, s. 206 i n. 
atorów ${ }^{55}$. Nie bez znaczenia były też przenikające do kraju informacje o planach przebudowy społeczno-gospodarczej na Zachodzie ${ }^{56}$. Trzeba mieć ponadto na uwadze, że w społeczeństwie polskim dokonywała się w czasie wojny radykalizacja postaw i narastało przekonanie o potrzebie głębszych przemian społecznoustrojowych.

W tym kontekście kształtowały się koncepcje programowe Departamentu znajdujące wyraz w jego projektach i opracowaniach. Zamykając tę część artykułu, powtórzmy raz jeszcze najważniejsze sformułowane w nich postulaty: gospodarka planowa skojarzona $\mathrm{z}$ rozbudową samorządu, umocnienie roli skonsolidowanego ruchu zawodowego, powszechne prawo do pracy sprawiedliwie wynagradzanej i cenionej odpowiednio do jej społecznego znaczenia, podźwignięcie gospodarcze i kulturalne szerokich rzesz robotniczych i chłopskich, przeobrażenie struktury społeczno-gospodarczej kraju oraz pchnięcie jego rozwoju na nowe tory - oto główne myśli składające się w sumie na wizję nowej Polski, przetransponowane w pracach Departamentu na płaszczyznę postulowanych zmian w zakresie polityki społecznej i ustawodawstwa społecznego. Dodajmy jeszcze, że wizja ta w ogólnym swym wyrazie sprowadzała się do wydźwignięcia kraju na taki poziom, na którym takie jak w tamtych latach ,śmiertelne zagrożenie naszego bytu (stałoby się) już niemożliwe"s7.

\section{IV}

Wybuch powstania uniemożliwił kontynuowanie opisanych wyżej prac Departamentu. Prace koncepcyjne zostały przerwane, do czego przyczyniła się śmierć Stefana Matei i rozproszenie znacznej części współpracowników. Działalność opiekuńcza w stosunku do ludności Warszawy prowadzona była w czasie powstania, w granicach możliwości, przez rejonowe delegatury Rządu, a także przez placówki RGO i PCK. Szeroki zakres pomocy żywnościowej oraz odzieżowej i mieszkaniowej rozwinęła zwłaszcza delegatura okręgu WarszawaPołudnie, w której kierownikiem działu opieki był Stanisław Kulesiński ${ }^{58}$. Departament Pracy i Opieki Społecznej, na czele którego stanął po śmierci Stefana Matei Franciszek Białas, nie miał w tym czasie większych możliwości działania,

${ }^{55}$ Por. S. Ajzner, Związek Związów Zawodowych 1931-1939. Warszawa 1979, s. 343 i n.

${ }^{56}$ Program Brytyjskiej Partii Pracy (wydany konspiracyjnie drukiem Warszawa 1943), zawierający m.in. postulat wprowadzenia gospodarki planowej oraz Plan Beveridge'a. O bliższe informacje i materiały z tego okresu upominał się Mateja w piśmie z 17 VI 1944 (por. wyżej przypis 8 ).

${ }^{57}$ Sprawozdanie Departamentu I-III 1944, s. 3.

${ }^{58}$ Por. B. Kroll, Opieka i samopomoc społeczna w Warszawie 1939-1945. Warszawa 1977, s. 246 i n., a także relację S. Kulesińskiego w: Ludność cywilna w powstaniu warszawskim. Warszawa 1974. t. I. cz. II, s. 386 i n. oraz K. Dunin-Wąsowicz, Warszawa w latach 1939-1945. Warszawa 1984, s. 337. 
interesował się jednak żywo akcją opieki i samopomocy społecznej oraz starał się udzielać jej poparcia ${ }^{59}$.

Po powstaniu akcja opieki społecznej nad wysiedleńcami z Warszawy, a także nad ludnością ewakuowaną z terenów przyfrontowych, nabrała ogromnego znaczenia. Sprawami tymi zajmowała się bezpośrednio Komisja Główna w składzie przedstawicieli czterech stronnictw, działająca w zastępstwie Rady Jedności Narodowej. Departament Pracy i Opieki Społecznej objął kierownictwo całości tej akcji, która prowadzona była przede wszystkim przez RGO i PCK. Instytucje te stały się w związku z tym organami wykonawczymi Departamentu, otrzymywały od niego znaczne sumy pieniężne $\mathrm{w}$ dolarach i działały zgodnie $\mathrm{z}$ udzielanymi im wytycznymi ${ }^{60}$.

Centralne kierownictwo całością akcji opiekuńczej sprawował Franciszek Białas, z którym współdziałał ściśle dyrektor biura RGO w Krakowie Edmund Seyfried ${ }^{61}$. Szeroki zakres akcji opieki nad wysiedleńcami z Warszawy, przede wszystkim na terenie Częstochowy, prowadził Stanisław Stęplewski, z którym współpracował Zbigniew Baucz. W pracach organizacyjnych związanych z akcją opieki uczestniczył Wacław Szubert, pozostając nadal zastępcą dyrektora Departamentu. W ścisłym kontakcie z Franciszkiem Białasem był Zbigniew Madeyski, który już przed powstaniem współpracował z Departamentem ${ }^{62}$. Bliższe udokumentowanie akcji opieki w tym czasie wymagałoby specjalnych badań, niełatwych zresztą do przeprowadzenia ze względu na jej charakter i warunki.

W okresie popowstaniowym działał nadal sekretariat Departamentu pod kierunkiem Alicji Eysmontówny, który utrzymywał kontakt z pracownikami Departamentu, jacy znajdowali się w tym czasie na terenie Generalnego Gubernatorstwa, oraz z członkami ich rodzin. Zakończenie działalności Departamentu nastąpiło w wyniku podjęcia decyzji o rozwiązaniu Delegatury Rządu w lipcu 1945 r. ${ }^{63}$

${ }^{59}$ Por. B. Kroll, Rada Główna Opiekuńcza 1939-1945. Warszawa 1985, s. 469. Apel Departamentu Pracy i Opieki Społecznej w sprawie samopomocy społecznej został ogłoszony w biuletynie: „Wiadomości z Miasta i Wiadomości Radiowe” z 6 VIII 1944, nr 7.

${ }^{60}$ Por. B. Kroll, Rada Główna Opiekuńcza..., s. 474 i n.

${ }^{61}$ Por. B. Kroll, Opieka i Samopomoc Społeczna..., s. 303.

${ }^{62}$ Por. Zbigniew Władysław Stanisław Madeyski, Podsumowanie żywota i jego dorobku, Wykonane w okresie lat 1968-1980. maszynopis, ss. 139-146 (zbiory Andrzeja Madeyskiego).

${ }^{63}$ Decyzja ta została podjęta na ostatnim posiedzeniu Rady Jedności Narodowej 5 VII 1945. Por. J. Braun. K. Popiel, K. Sieniewicz, Człowiek ze spiżu. Londyn 1981, ss. 194-195. 


\section{Aneks II}

\section{Waclaw Szubert \\ Wspomnienia o Departamencie Pracy i Opieki Społecznej Delegatury Rządu (1941-1944) \\ (przedruk z czasopisma „Przegląd Historyczny” 1989, z. 1)}

Z Departamentem Pracy i Opieki Społecznej Delegatury Rządu byłem związany od połowy 1941 r., najpierw na zasadzie luźniejszej współpracy, a następnie ścisłej przynależności organizacyjnej. Brałem czynny udział w dwóch ważnych dziedzinach działalności Departamentu, a mianowicie w pracach koncepcyjnych, dotyczących kształtu polityki społecznej w przyszłej Polsce oraz w akcji pomocy i opieki nad ofiarami terroru okupanta i przedstawicielami środowisk szczególnie zagrożonych jego polityką eksterminacyjną. Pierwszej z tych dziedzin poświęcam osobne obszerniejsze opracowanie, które znajduje się w stadium daleko posuniętego przygotowania. Drugiej nie dałoby się już chyba opracować w sposób pełniejszy ze względu na trudność zgromadzenia odpowiedniej dokumentacji; o znaczeniu jej świadczą jednak liczne wzmianki w literaturze dotyczącej okresu okupacji.

Szkic niniejszy nie nawiązuje bezpośrednio do żadnego z tych wątków. Przyświeca mu natomiast intencja uzupełnienia obrazu, jaki wyłania się stopniowo z opracowań analitycznych, przez zarysowanie postaci ludzi, którzy stanowili trzon organizacyjny Departamentu Pracy i Opieki Społecznej i których działalność wywierała decydujący wpływ na jego prace i rozwój.

W pamięci mojej utkwiły mocno sylwetki niektórych zwłaszcza spośród tych ludzi, do jakich dane mi było zbliżyć się i z nimi współpracować. Z pamięci tej pragnę wydobyć wspomnienia o charakterze osobistym, z natury rzeczy selektywne, skupiające się wokół osób zmarłych, bez dawania pełniejszych charakterystyk czy też przedstawiania pełnego składu współpracowników Departamentu.

Wśród osób tych wysuwa się na plan pierwszy postać Jana Stanisława Jankowskiego, który stał na czele Departamentu w latach 1941-1943, a następnie 
- po przejściu na stanowisko Delegata Rządu na Kraj, a więc szefa wszystkich komórek organizacyjnych delegatury - interesował się nadal żywo jego pracami.

Z Janem Stanisławem Jankowskim zetknąłem się po raz pierwszy na kilka lat przed wojną, w okresie mojej pracy w Instytucie Spraw Społecznych w Warszawie, ważnym ośrodku prac badawczych i postępowej myśli społecznej, skupiającym grono wybitnych jej przedstawicieli. Głębokim przeżyciem było dla mnie, jako dla bardzo młodego wówczas adepta nauki, znalezienie się w tym środowisku, nie mającym bezpośrednich powiązań z nauką akademicką, reprezentującym natomiast ogromny zasób żywej wiedzy, czerpanej z praktyki i doświadczenia. Jako asystent jednego z działów Instytutu i sekretarz jego Rady Naukowej miałem możność przysłuchiwania się wielu dyskusjom, mającym za przedmiot czy to ogólniejsze plany prac badawczych, czy też koncepcje poszczególnych badań i roztrząsanie związanych z nimi problemów, czy wreszcie obmyślanie różnych form działania i wydawnictw. Z prac tych wyłaniał się ogólniejszy nurt myśli badawczej i koncepcyjnej, zmierzającej do przedstawienia rzetelnego obrazu współczesnej rzeczywistości społecznej oraz wskazywania najskuteczniejszych środków mogących przyczynić się do pożądanych zmian. Kształtowały się w ten sposób w toku bieżących prac Instytutu zręby nauki polityki społecznej, formowane przez ludzi światłych i twórczych, jakkolwiek nie mających na ogół tytułów naukowych ${ }^{1}$.

Należał do nich przede wszystkim dyrektor Instytutu Kazimierz Korniłowicz, niezrównany inicjator i animator prac badawczych i instrukcyjnych, należeli do nich także wybitni znawcy problemów rynku pracy: Edward Strzelecki i Ludwik Landau, ubezpieczeniowcy - jak Wacław Bruner, Zbigniew Łomnicki czy Henryk Greniewski, znawcy zagadnień bezpieczeństwa i higieny pracy - jak Edward Mazurkiewicz i Wacław Adamiecki, problematyki zdrowia publicznego - jak Marcin Kacprzak i wielu innych.

Do tych najwybitniejszych znawców zagadnień polityki społecznej, uczestniczących w szerokim zakresie prac Instytutu, należał też Jan Stanisław Jankowski, stały członek jego Rady Naukowej i wielu gremiów powoływanych dla dyskutowania i rozwiązywania określonych problemów. Główną domenę Jana S. Jankowskiego stanowiły ubezpieczenia społeczne, z którymi był związany w ostatnich latach przed wojną miejscem swej pracy. Reprezentował on jednak głęboką wiedzę także i w innych dziedzinach polityki społecznej, co umożliwiało mu oddziaływanie na kierunek i formy wielu prac Instytutu. Zabierał on głos przy

${ }^{1}$ Dorobek Instytutu Spraw Społecznych nie doczekał się jeszcze monograficznego opracowania. W ostatnich latach ukazały się dwie publikacje: H. Kuropatwińska-Swidowa, Ze wspomnień o Instytucie Spraw Spolecznych w Warszawę (1931-1939), „Studia i Materiały z Historii Ubezpieczeń Społecznych w Polsce" z. 2, Warszawa 1984, s. 99-110 oraz Trójglos o Instytucie Spraw Społecznych $w$ Warszawie z okresu okupacji (Wacław Szubert, Jerzy Piotrowski, Stefan Mateja), ibidem, z. 4, Warszawa 1986, s. 157-176. 
różnych okazjach; pozostały mi w pamięci liczne jego wystąpienia na posiedzeniach Rady Naukowej i na innych zebraniach, zawsze nacechowane rzeczowością i trzeźwością sądów oraz konstruktywne w poszukiwaniu optymalnych rozwiązań dyskutowanych problemów. Ten ważny wkład Jana S. Jankowskiego był wysoko ceniony w środowisku Instytutu Spraw Społecznych, czemu niejednokrotnie dawano wyraz.

Stwierdzenia te dotyczą okresu 1936-1939, kiedy to byłem pracownikiem Instytutu Spraw Społecznych. Wojna i okupacja położyły kres pracom Instytutu, tym boleśniejszy, że naznaczony tragicznym odejściem wielu jego współpracowników, a wśród nich, od razu w pierwszych dniach września 1939, dyrektora Kazimierza Korniłowicza. Pozostali pracownicy zbierali się jeszcze w ciągu października i listopada w lokalu Instytutu przy ul. Wilczej 1, stawało się jednak rzeczą jasną, że nie będzie szans na kontynuowanie legalnej działalności Instytutu $\mathrm{w}$ jego dotychczasowych formach.

Wtedy właśnie Jan S. Jankowski, podczas jednej ze swych wizyt w lokalu Instytutu Spraw Społecznych, zaproponował mi, abym przeszedł do pracy w Stołecznym Komitecie Samopomocy Społecznej w charakterze sekretarza kierowanej przez niego komórki organizacyjnej tego Komitetu: sekcji do spraw pracy. Dodał przy tym, że w istniejącej sytuacji jest to w jego przekonaniu dobra dla mnie propozycja. Nie musiał mnie jednak do jej przyjęcia namawiać - zgodziłem się bez wahania, choć żal mi było Instytutu. Szanse jego dawnej działalności zamknęły się bowiem bezpowrotnie, a propozycja Jana S. Jankowskiego otwierała przede mną możliwości nowej, interesującej i pożytecznej pracy, służącej dobrej sprawie.

Te przewidywania w pełni się potwierdziły. Stołeczny Komitet Samopomocy Społecznej w pierwszych miesiącach okupacji stanowił szczególne środowisko skupiające wielu wybitnych przedstawicieli naszego życia publicznego i kulturalnego na skromnych formalnie stanowiskach organizatorów i wykonawców w różnych działach pracy opiekuńczej, która miała służyć najpilniejszym potrzebom zubożałego i boleśnie dotkniętego przez wojnę społeczeństwa.

Praca ta nosiła w początkowej fazie wiele cech działalności społecznej, prowadzonej na zasadach wewnętrznej samorządności. Osoby znajdujące się na naczelnych stanowiskach kierowniczych w Komitecie nie pobierały w ciągu dłuższego czasu żadnego wynagrodzenia, a pracownicy zostali zrównani pod względem uposażenia na skromnym wówczas poziomie płacy wynoszącej $250 \mathrm{zł} \mathrm{miesięcznie.} \mathrm{Wśród} \mathrm{jednych} \mathrm{i} \mathrm{drugich} \mathrm{znajdowały} \mathrm{się} \mathrm{przy} \mathrm{tym} \mathrm{osoby,} \mathrm{które}$ byłyby predestynowane, ze względu na swe przedwojenne stanowiska i kwalifikacje, do wykonywania zupełnie innych prac. Niezapomniane wrażenie sprawiała ta tragicznie pomniejszona i zagrożona $\mathrm{w}$ swej dalszej egzystencji reprezentacja niezależnego w jakiejś mierze polskiego życia, która mogła jeszcze działać w legalnych formach. Na małej przestrzeni lokalu przy ul. Wiejskiej 10 (gmach byłej Izby Przemysłowo-Handlowej) można było wówczas przeżyć niejedno niezwykłe 
spotkanie. Przybywało też ciągle sporo nowych ludzi, ale niestety zaczęli również ubywać ci, którzy byli wyrywani policyjną ręką okupanta z naszych szeregów, aby nigdy już do nich nie powrócić 2 .

Sekcja do spraw pracy, jedna z sekcji, które działały w ramach Komitetu, miała za zadanie dopomaganie ludziom pozbawionym poprzednich możliwości pracy, a tym samym i środków do życia, przez udzielanie pożyczek, które miały umożliwić im stworzenie skromnych, samodzielnych placówek pracy o charakterze indywidualnym, bądź spółdzielczym. Założenie to nie zawsze dawało się urzeczywistnić, zarówno ze względu na skromny wymiar udostępnianych środków, jak i brak niezbędnego doświadczenia i obrotności wśród wspomaganych osób, a także ze względu na nieustabilizowane warunki ówczesnego życia w początkowym okresie okupacji. Pomoc pieniężna miała jednak znaczenie psychologiczne, pozwalała niejednokrotnie przetrwać szczególnie trudny okres przystosowania do dramatycznie zmienionych warunków oraz zachęcała do podejmowania starań by zorganizować podstawy egzystencji na przyszłość.

Zasady udzielania tej pomocy, jej wymiar materialny i warunki ustalił w początkowym okresie Jan S. Jankowski; następnie były one stopniowo precyzowane w praktyce, czemu sprzyjały okoliczności towarzyszące działalności sekcji. W jednym niewielkim pokoju, przez który przechodził nie kończący się korowód ludzi poszukujących wsparcia, funkcjonował cały aktyw, czy też personel Sekcji w osobach jej przewodniczącego: Jana S. Jankowskiego, zastępcy przewodniczącego, którym był Antoni Zdanowski i sekretarza w mojej osobie. Każda sprawa mogła być w tych warunkach gruntownie rozpatrzona i rozstrzygnięta bezpośrednio, bez biurokratycznej mitręgi, co również sprzyjało konkretyzowaniu zasad, które miałyby obowiązywać w przyszłości w podobnych przypadkach. Korowód owych przyjmowanych przez nas osób, do których nie pasowałaby nazwa interesantów, miał dość niezwykły skład. Znaczną jego część stanowili wybitni przedstawiciele świata kultury, którzy zostali pozbawieni dawnych możliwości pracy, bądź też nie chcieli w warunkach okupacyjnych wykonywać swego zawodu (jak aktorzy).

Jedni z pierwszych zostali wpisani do księgi dokumentującej działalność Sekcji czterej pisarze: Jerzy Andrzejewski, Tadeusz Breza, Michał Choromański i Stefan Otwinowski, którzy otrzymali pożyczkę w wysokości 800 ówczesnych złotych na handel uliczny książkami. Pamiętam ich wszystkich zgromadzonych w naszym pokoju i składających swe podpisy na stosownym dokumencie. Potem byli m.in. Helena Boguszewska i Jerzy Kornacki reprezentujący grupę „Przedmieście”, Wanda Melcer w imieniu grupy literatów zrzeszonych w założonej wówczas spółdzielni, a ze świata teatru Dobiesław Damięcki, który później musiał się ukrywać w związku ze sprawą Igo Syma, Teofil Trzciński na czele grupy artystów Opery i wielu, wielu innych.

\footnotetext{
${ }^{2}$ Należeli do nich: Jan Łazowski, Roman Rybarski, Jan Strzelecki.
} 
Odmienną, stosunkowo liczną kategorię zgłaszających się do nas osób stanowili wysiedleńcy z Poznańskiego, którzy przychodzili zazwyczaj bezpośrednio po przymusowym przetransportowaniu do tzw. Generalnego Gubernatorstwa i przybyciu do Warszawy. Trzeba było podziwiać postawę tych dzielnych ludzi, którym kazano w ciągu 15 minut opuścić ich domy i zostawić cały dobytek, poza skromnym ręcznym bagażem. Wyrażali oni niezachwianą pewność, że tam powrócą oraz przejawiali wiele energii i zaradności w prowizorycznym urządzaniu swego życia w miejscu przesiedlenia, co pozwoliło im stworzyć sobie z czasem znośne warunki bytu.

Wiedzieliśmy o tym, gdyż z wieloma osobami korzystającymi z naszej pomocy utrzymywaliśmy trwalszy kontakt; niektórzy z nich po spłaceniu otrzymanych pożyczek (co ułatwiała dewaluacja pieniądza) zaciągali nowe, już na ściśle określone cele. Staraliśmy się, na miarę ówczesnych warunków i możliwości, gromadzić dokumentację obrazującą efektywność prowadzonej przez nas działalności, czym żywo interesował się Jan S. Jankowski.

Akcja pożyczek na cele usamodzielnienia gospodarczego stanowiła w ogóle przedmiot jego szczególnej uwagi, także i wtedy gdy zinstytucjonalizowała się ona na tyle, że nie musiał wnikać bezpośrednio w poszczególne przypadki. Sprawiała mu też dużo zadowolenia, ponieważ rozwijała się stosunkowo dobrze, na gruncie ustalonych zasad, nie przeradzając się w zwykłe rozdawnictwo pieniędzy bez myśli przewodniej i kontroli.

Poza tą działalnością Jan S. Jankowski zainicjował w ramach naszej Sekcji akcję popierania pracowniczych ogródków działkowych, która rozwinęła się bardzo w warunkach okupacji, przynosząc realną korzyść ludności Warszawy; zajmowała się tym Zofia Brzywczy-Kunińska. Powołał również komisję prawniczą przy naszej Sekcji, która miała wyjaśnić problemy prawne o znaczeniu społecznym, jakie stwarzało wprowadzenie reżimu okupacyjnego. Na czele tej komisji stanął sędzia Pierzchalski, a członkami jej byli m.in. Stefan Mateja, Stanisław Kędzierski, a także, o ile mnie pamięć nie myli, Zbigniew Wróblewski i Zygmunt Kopankiewicz. Zbierała się ona dość często, poczynając już od grudnia 1939, w owym jedynym pokoju stanowiącym lokal Sekcji, poza godzinami jej zwykłej działalności, przy czym Jan S. Jankowski w początkowej fazie uczestniczył w jej obradach.

Na początku 1940 r. warunki pracy Sekcji zmieniły się na tyle, że uzyskała ona dwupokojowy lokal na wyższym piętrze w tym samym gmachu. W ten sposób powiększyła się jej przestrzeń dyspozycyjna, niestety zupełnie nieogrzewana, co w warunkach surowej zimy $1940 \mathrm{r}$. stwarzało sytuację trudną do wytrzymania. Temperatura $\mathrm{w}$ naszych pomieszczeniach spadała poniżej $0^{\circ}$ (atrament zamarzał w kałamarzach), trudno więc było normalnie wysiedzieć przy biurkach: praca odbywała się w ciągłym ruchu i w pełnym wyjściowym rynsztunku zimowym. Pamiętam, jak w takich okolicznościach finalizowaliśmy udzielenie pożyczki H. Boguszewskiej i J. Kornackiemu, biegając po pokoju i zdejmując rękawiczki 
tylko na moment wypełnienia stosownych formularzy i składania podpisów. A z pobliskiego terenu Sejmu dochodziły do nas odgłosy salw karabinowych, oznaczających dokonywane tam egzekucje.

Z nadejściem wiosny ustąpiły wspomniane poprzednio dokuczliwości, a na jesieni 1940 r. nastąpiła przeprowadzka do gmachu „Romy” przy ul. Nowogrodzkiej, a wkrótce potem charakteru naszej instytucji. Stołeczny Komitet Samopomocy Społecznej został przekształcony w Radę Opiekuńczą Miejską, działającą w ramach Rady Głównej Opiekuńczej, mającej swą siedzibę w Krakowie. Z tą chwilą znikły wszelkie przejawy społecznej samorządności i kolegialnych form działania. Instytucja nasza przekształciła się w wielką biurokratyczną maszynę, której charakter był bardziej przystosowany do okupacyjnych warunków. Trzeba przy tym przyznać, że była ona na ogół sprawnie kierowana i pozostawiała sporo możliwości organizowania pod jej przykrywką nielegalnych form działania.

Wiele zmian też zaszło w naszej Sekcji, przemianowanej obecnie na Dział do spraw pracy. Na miejsce Antoniego Zdanowskiego przyszedł Franciszek Białas, rozbudowała się też poważnie obsada personalna, w ramach której znaleźli się m.in. Jan (?) Kordowski, Stanisław Roman Dangel, Wacław Czarnecki, Janina Gadomska, Alicja Eysmontówna i wiele innych osób, spełniających te same co dawniej funkcje w nieporównanie szerszym zakresie. Trudno było w istocie porównać to wielkie biuro, jakie stanowił teraz nasz Dział, ze skromną sekcją zajmującą w końcu 1939 r. jeden pokoik przy Wiejskiej. Charakter działalności pozostał jednak ten sam, choć doszły m.in. sprawy mieszkaniowe. W powiększonym znacznie zespole ludzkim panowała harmonia i pełne zrozumienie.

W działalności tej umacniał się przy tym coraz bardziej nurt podskórny, wynikający nie tylko stąd, że dawała ona pokrycie różnym nielegalnym poczynaniom (tak np. przy naszym Dziale funkcjonował, zakamuflowany pod nazwą Komisji Statystycznej, Instytut Gospodarstwa Społecznego) ${ }^{3}$. Ważniejsza jeszcze była ta okoliczność, że prawie każda z bardziej eksponowanych osób w naszym Dziale brała udział w pracach konspiracyjnych, które niekiedy się ze sobą zazębiały. Życie i praca toczyły się więc niejako na dwóch płaszczyznach, przy czym ta podziemna wciągała coraz bardziej, ale ta legalna, czy quasi legalna - w RGO, wymagała również dużego zaangażowania, ponieważ chodziło w niej o sprawy społecznie ważne w ówczesnej okupacyjnej rzeczywistości.

Istnienie owego podskórnego nurtu dawało jawnie znać o sobie, gdy zachodził fakt, wyłączający daną osobę z normalnych form życia. U mnie dokonało się to bezboleśnie, ponieważ udało mi się uniknąć niepożądanego spotkania. Niektórzy nasi koledzy stali się jednak ofiarami represji i zapłacili za swe patriotyczne zaangażowanie najwyższą cenę4.

\footnotetext{
${ }^{3}$ Por. T. Szturm de Sztrem, Instytut Gospodarstwa Społecznego, Warszawa 1959, s. 216 i n.

${ }^{4}$ Stanisław Roman Dangel został zamordowany bezpośrednio po aresztowaniu w roku 1942, Jan Kordowski zmarł w Oświęcimiu w roku 1943 (?).
} 
W ciągu dwóch lat (od grudnia 1939 do listopada 1941) dane mi było pracować pod bezpośrednim kierunkiem Jana S. Jankowskiego i w codziennej z nim styczności, w opisanych warunkach. W wielu sytuacjach miałem możność obserwować jego reakcje, jego linię postępowania i różne przejawy działalności jako organizatora i kierownika stworzonej przez niego placówki pracy opiekuńczej. Zbliżyłem się też do niego już wtedy w nurcie konspiracyjnym, do czego przyczyniła się moja służba w Wydziale Informacji BIP ZWZ (później AK), a następnie współpraca z Departamentem Pracy i Opieki Społecznej Delegatury Rządu, którego kierownictwo Jankowski objął wiosną $1941 \mathrm{r}$. W toku tych wszystkich kontaktów mogłem w pełni ocenić wysokie walory jego umysłu i charakteru, które były przedmiotem powszechnego szacunku w naszym środowisku. Szczery podziw wzbudzał jego niewzruszony spokój i opanowanie, trzeźwość sądu pozwalająca mu zawsze znajdować trafne rozwiązanie w skomplikowanych sytuacjach, a nade wszystko jego głębokie patriotyczne zaangażowanie we wszelką działalność służącą polskiej sprawie.

Jan S. Jankowski nie był człowiekiem wylewnym i uczuciowym. Kontakty z nim były nacechowane rzeczowością, z pozoru suche ze względu na dużą oszczędność słów, ale zawsze znamionujące wielką kulturę osobistą. Niełatwo było wejść z nim w bezpośrednią osobistą zażyłość, można było natomiast niezawodnie polegać na jego słowie i prawości jego intencji. Jako kierownik pracy zespołowej umiał nadawać jej właściwy kształt organizacyjny, natomiast w podejmowaniu szczegółowych decyzji przejawiał niekiedy pewną apodyktyczność, nie przygotowując ich dostatecznie przez uprzednie rozmowy ze współpracownikami. W działalności na terenie SKSS czy RGO nie stwarzało to poważniejszych problemów. Zastanawiałem się jednak nieraz nad tym, czy ta cecha postępowania Jankowskiego nie mogła zaważyć na niektórych jego późniejszych decyzjach w sprawach najwyższej wagi.

W listopadzie 1941 r. urwał się mój kontakt z RGO i odtąd miałem już styczność z Janem S. Jankowskim wyłącznie na gruncie działalności konspiracyjnej, biorąc udział w pracach koncepcyjnych prowadzonych przez Departament Pracy i Opieki Społecznej oraz w niektórych zakresach opieki czynnej sprawowanej przez tenże Departament. Współpraca ta stopniowo ulegała zacieśnieniu w miarę tego, jak rozwijały się prace koncepcyjne Departamentu, których bezpośrednie kierownictwo należało do Stefana Matei; uzasadniały one jednak również potrzebę kontaktu osobistego z Janem S. Jankowskim.

W połowie 1943 r. zaszedł w tej współpracy moment przełomowy, związany z objęciem przez Jankowskiego stanowiska Delegata Rządu oraz powołaniem Matei na stanowisko dyrektora Departamentu Pracy i Opieki Społecznej. Zaproponował mi wówczas Jankowski pełne włączenie się do pracy w Departamencie w charakterze zastępcy dyrektora. W ten sposób, już po raz drugi w okresie okupacji, jego inicjatywa miała wpłynąć zasadniczo na moją sytuację życiową. Muszę jednak przyznać, że tym razem, w przeciwieństwie do decyzji 
z końca 1939 r., akceptacja tej zmiany nie przyszła mi łatwo. Wymagała bowiem odejścia z Wydziału Informacji BIP AK, w którym prowadziłem od marca $1940 \mathrm{r}$. referat społeczny, czując się z tą pracą głęboko związany zwłaszcza od czasu, gdy zaczęła ona służyć celom walki konspiracyjnej i przygotowywaniu akcji zbrojnych ${ }^{5}$. Istotny sens tej pracy sprowadzał się bowiem do bezpośredniego udziału w walce z okupantem, podczas gdy w Delegaturze dominowały sprawy polityczne, związane z przygotowaniami na chwilę przełomu.

Jeśli jednak zdecydowałem się ostatecznie przejść do Departamentu (co przybrało formalną postać odkomenderowania), to rozstrzygnął o tym szacunek i głębokie zaufanie, jakie żywiłem zarówno do Jana S. Jankowskiego jak i Stefana Matei, pod którego kierunkiem miałem odtąd pracować. Na tym zaufaniu nigdy się nie zawiodłem, a poza tym praca w Departamencie zaczęła mi wkrótce przynosić również duże zadowolenie ze względu na jego zadania w zakresie opieki czynnej oraz z uwagi na szczególny klimat, jaki stwarzała postawa ideowa Matei. Praca ta dawała też niewątpliwie większe możliwości spożytkowania (i rozwijania) moich kwalifikacji zawodowych.

U progu tej nowej fazy działalności konspiracyjnej zostały mi powierzone odpowiedzialne zadania w zakresie organizacji opieki czynnej, która obejmowała ofiary terroru politycznego okupanta (a więc osoby przebywające w więzieniach, obozach koncentracyjnych) i członków ich rodzin, wysiedleńców, osoby ukrywające się, rodziny osób pomordowanych, później w szczególności rozstrzelanych (tzw. akcja RR) oraz jednostki wartościowe społecznie, znajdujące się w potrzebie. Do tej ostatniej kategorii zaliczano nie tylko przedstawicieli świata nauki i kultury, lecz również innych środowisk, a decydujące kryterium stanowił poziom moralny, postawa obywatelska oraz stan potrzeby, uzasadniający udzielenie pomocy ${ }^{6}$.

Zasady prowadzenia tej akcji o nastawieniu specjalnym, odróżniającym ją od ogólnej opieki społecznej, prowadzonej z legalnych źródeł przez gminy miejskie i wiejskie oraz przez placówki RGO, ustalił Jan S. Jankowski. On też starał się stale o zwiększanie środków przeznaczonych na ten cel i dbał o przestrzeganie ustalonych zasad i prawidłowe dysponowanie funduszami. Departament Pracy i Opieki Społecznej stanowił w tej akcji centralny ośrodek dyspozycyjny i główny punkt rozdziału funduszów pomiędzy różne ośrodki legalne (jak RGO) czy nielegalne (jak Patronat nad Więźniami, okręgi Delegatury Rządu), prowadzące bezpośrednio działalność opiekuńczą, przy czym zasadnicza jej forma polegała

${ }^{5}$ Ten aspekt działalności Wydziału Informacji BIP AK nie został moim zdaniem dostatecznie uwydatniony w pięknej książce G. Mazura, Biuro Informacji i Propagandy SZP-ZWZ-AK, Warszawa 1987. Nieścisłe jest zwłaszcza stwierdzenie, że praca tego Wydziału nosiła „wyłącznie analityczny charakter" (s. 90).

${ }^{6}$ Por. CA KC PZPR 203/VII-35, Ł 2, s. 112 i n.: Sprawozdanie Pracy i Opieki Społecznej za okres 1 VIII - 31 XII 1943 oraz instrukcje dla Okręgów i komórek powiatowych w sprawie opieki czynnej (ibidem, 2G2/VIII, s. 8-10). 
na zapomodze pieniężnej okresowej lub jednorazowej (m.in. na paczki dla więźniów) o ustalonej maksymalnej wysokości.

W połowie 1943 r. została mi powierzona organizacyjna strona owego centralnego punktu dyspozycji, co wprowadziło mnie w całokształt tej akcji oraz uzasadniało znowu bliski kontakt z Jankowskim. Interesował się on nadal tą akcją, pomimo objęcia naczelnego stanowiska kierowniczego w Delegaturze Rządu. Oznaczało to odbieranie bezpośrednio od niego wskazówek i dyspozycji oraz odpowiedzialność za sprawne przejmowanie, przechowywanie i rozprowadzanie funduszów przy wykorzystaniu lokali, które zostały mi oddane do dyspozycji (dwa najważniejsze przy ul. Moniuszki i przy ul. Elektoralnej służyły również w pewnej mierze jako punkty kontaktowe dla Jana S. Jankowskiego).

Podejmując ten zakres obowiązków, zdałem sobie rychło sprawę ze szczególnych problemów, które stwarzała w ramach działalności konspiracyjnej kontrola nad prawidłowością spożytkowywania funduszów przeznaczonych na cele opieki czynnej. Względy bezpieczeństwa wymagałyby ograniczenia do minimum wszelkich formalności i związanej z nimi dokumentacji. Dużą rolę musiał też odgrywać czynnik zaufania, związany z właściwym doborem osób uczestniczących w pracy konspiracyjnej. Z drugiej strony nie można było jednak rezygnować z rygorów, jakich wymaga w każdym środowisku obrót pieniędzy, aby zapobiec mimowolnym choćby uchybieniom i nieścisłościom.

Jan S. Jankowski przywiązywał wielką wagę do tej kontroli, jakkolwiek zdawał sobie sprawę z ograniczonych możliwości jej zastosowania w warunkach konspiracji. Fundusze na rzecz instytucji i ośrodków prowadzących bezpośrednio akcję opieki z ramienia Delegatury były przyznawane na podstawie przedstawionych przez nie preliminarzy, a następnie wymagano składania sprawozdań ze sposobu ich wykorzystania (co dwa miesiące). Przy świadczeniach przyznawanych bezpośrednio przez kierownictwo Departamentu zbierano potwierdzenia odbioru sporządzane według odpowiedniego klucza, a następnie kwity te i rozliczenia były komisyjnie sprawdzane i niszczone.

Jankowski narzucał sobie także te rygory w stosunku do akcji opiekuńczej, którą osobiście prowadził, i to nawet wtedy, gdy objął stanowisko Delegata Rządu. Nauczyłem się szanować tę skrupulatność w sprawach pozornie błahych (w zestawieniu z zakresem ciążących na nim odpowiedzialności), ale zawsze delikatnych, jak wszystko to co dotyczy pieniędzy, zwłaszcza w warunkach ograniczonej formalnej kontroli. Zawierał się w tym także wzór postępowania dla współpracowników. W całym omawianym teraz okresie miałem z Jankowskim bliski kontakt osobisty. Bywałem też stosunkowo często w jego prywatnym mieszkaniu przy ul. Kaszyńskiej 52, w którym mieszkał cały czas legalnie i przyjmował, wbrew zasadom ścisłej konspiracji, swych najbliższych współpracowników.

Na początku 1944 r. w organizacji akcji opieki czynnej zaszła zmiana. Główny punkt rozdziału funduszów przejął Stanisław Stęplewski, o czym zadecydowały względy praktyczne, można było bowiem w ten sposób oprzeć całą akcję o biuro 
RGO, w której był on legalnie zatrudniony, odciążyć od niej natomiast konspiracyjne lokale. Ułatwiało to również technicznie Jankowskiemu kontakt z punktem rozdziału funduszów, gdyż pozostawał on także w związku z RGO, jakkolwiek nie pełnił już w niej poprzednich funkcji.

Sprawy opieki czynnej należały do mnie odtąd w takim zakresie, w jakim wiązały się z wewnętrzną organizacją prac Departamentu, które były objęte zakresem mych funkcji. Punkt ciężkości zadań, w których wykonywaniu uczestniczyłem, przesunął się natomiast ku pracom koncepcyjnym, które nabierały coraz większego tempa i konkretyzowały się w miarę zbliżania się momentu przełomu, na jaki obliczone były projekty przygotowywane przez nas.

Następna, i ostatnia już, faza moich kontaktów z Jankowskim przypadła na okres powstania warszawskiego, od chwili gdy kierownictwo Delegatury znalazło się w północnej części śródmieścia (w gmachu PKO przy ul. Świętokrzyskiej). W tym rejonie znalazłem się również w drugiej połowie sierpnia 1944 r., a kontakt z centralnymi władzami Delegatury był dla mnie tym bardziej konieczny, że po tragicznej śmierci Stefana Matei w pierwszych dniach powstania, objąłem przejściowo funkcje dyrektora Departamentu. W trakcie parokrotnej styczności z Jankowskim podziwiałem jego spokój zewnętrzny i opanowanie w obliczu dramatycznego obrotu wydarzeń. Poznałem też jeszcze jedną jego cechę osobistą, a mianowicie odwagę, gdy zdarzyło mi się iść z nim w niewielkiej grupie przez plac noszący wówczas nazwę placu Napoleona w czasie gęstego obstrzału. Jankowski szedł pierwszy, wyprostowany, nie kłaniając się kulom, jakkolwiek była to kanonada mogąca zdeprymować najodważniejszych ludzi.

Ostatnie już nasze spotkanie miało miejsce pod koniec września 1944 r., w schronie przy ul. Mokotowskiej, którego strop rezonował od uderzeń pocisków padających raz po raz w pobliżu. Powstanie dobiegało końca, ciężki ostrzał pokrywał ostatnie miejsca pobytu jego dowództwa i władz cywilnych. Po tragicznym epizodzie przebywania na zagrożonym wciąż skrawku wolnego kraju, czekała nas nowa faza poniewierka i nie wyjaśniona przyszłość. Nie była to sytuacja zachęcająca do rozmów.

Jeszcze byłem świadkiem wymiany słów między konspiracyjnym prezydentem Warszawy Marcelim Porowskim a Kazimierzem Pużakiem w sprawie zasad ujawniania się wobec władz radzieckich. Jeszcze otrzymywałem instrukcje, jak zorganizować wyjście z miasta grupy współpracowników Departamentu po kapitulacji. Ale w istocie dominowało milczenie i narastająca świadomość końca. W tych okolicznościach wymieniłem z Janem S. Jankowskim ostatni, pożegnalny uścisk dłoni.

\section{II}

Stefan Mateja stał na czele Departamentu Pracy i Opieki Społecznej od marca 1943 r. do powstania warszawskiego. Wybitny prawnik, znany ze swej społecznej postawy sędzia sądów pracy, współpracownik Instytutu Spraw Społecznych 
i Polskiego Towarzystwa Polityki Społecznej, zajął to stanowisko dzięki swym szczególnym przymiotom osobistym, mimo że nie należał do żadnej partii, co uzasadniałoby jego nominację według przyjętego „klucza”. Nasze drogi krzyżowały się już przed wojną, ale były to kontakty okazjonalne, bez głębszej treści.

Zbliżyłem się do niego $\mathrm{w}$ pierwszych miesiącach okupacji w związku z jego udziałem w komisji prawniczej utworzonej przez Jana S. Jankowskiego przy sekcji do spraw pracy SKSS. Kontakt ten utorował drogę naszej współpracy w Wydziale Informacji BIP ZWZ, w którym Stefan Mateja zgodził się pełnić funkcję konsultanta przy kierowanym przeze mnie referacie społecznym (w drugiej połowie 1940 r.). Jego udział w tym charakterze był cennym dopełnieniem mojego skromnego jeszcze wówczas doświadczenia w tej odpowiedzialnej pracy. W sprawach natury ogólniejszej głos Matei był niezmiernie pożyteczny, niekiedy dochodziło do kontaktu między nim a moim szefem, kierownikiem Wydziału Informacji Jerzym Makowieckim.

W połowie $1941 \mathrm{r}$. Mateja objął kierownictwo prac koncepcyjnych prowadzonych w Departamencie Pracy i Opieki Społecznej i wówczas nasza współpraca przesunęła się, z jego inicjatywy, na tamtą płaszczyznę. W ciągu roku 1942 przewodniczył na zebraniach dyskusyjnych współpracowników Departamentu, które zmierzały do wypracowania ogólniejszych koncepcji i myśli programowych, dotyczących rozwoju polityki społecznej i prawa pracy w przyszłej Polsce. W tej roli dał się poznać jako inspirator wielu twórczych myśli i oryginalnych rozwiązań, nadając naszym pracom jednolity kierunek oraz ugruntowując atmosferę koleżeńskiego współdziałania, opartego na wzajemnym zrozumieniu i akceptacji określonych założeń ideowych. Gdy w marcu 1943 r. objął stanowisko dyrektora Departamentu, nadal sprawował kierownictwo tych prac oraz wnosił do nich duży własny wkład, starając się doprowadzić do przygotowania w najważniejszych dziedzinach projektów rozwiązań, ubranych w szatę prawną.

Stefan Mateja był szefem pełnym uroku. Nie miał w sobie nic z oficjalności dyrektora i nie sposobił się również do zajęcia żadnych eksponowanych stanowisk w przyszłości. Wbrew rozpowszechnionym w pewnych kołach postawom nie widział siebie w roli przyszłego szefa resortu. Mawiał niekiedy, że ministrem mógłby być tylko w bardzo nienormalnych czasach, odsuwając wyraźnie od siebie tę ewentualność. Najchętniej myślał, a może nawet marzył, o objęciu kiedyś kierownictwa wielkiego instytutu badawczo-koncepcyjnego, obejmującego szeroki zakres polityki społecznej. W jednej z naszych licznych rozmów wyraźnie wypowiedział się na ten temat. Tym też było uzasadnione jego żywe zainteresowanie losami i przyszłą rolą Instytutu Spraw Społecznych w Warszawie, do którego objęcia przymierzał się chyba w swoich myślach. Nie muszę dodawać, że ta postawa Stefana Matei przyciągała mnie do niego najbardziej i stwarzała pomiędzy nami płaszczyznę bliższego zrozumienia.

Był człowiekiem głęboko wewnętrznie zaangażowanym na rzecz postępu społecznego, ale równocześnie otwartym na wszelkie idee i koncepcje służące 
tej sprawie. Gruntowny znawca marksizmu, oczytany w literaturze syndykalistycznej, studiował gorliwie prasę podziemną wszelkich orientacji politycznych, starając się z niej wyłuskać zdrowe ziarna. Bliski już przed wojną ideom wyrażanym w dokumentach programowych Polskiej Partii Socjalistycznej, brał w czasie wojny żywy udział w pracach katolickiej „Unii” i zbliżył się w związku z tym do Stronnictwa Pracy. Był lojalnym pracownikiem Delegatury Rządu na Kraj, ale równocześnie przyznawał wiele racji głosom krytycznym przeciwko monopolowi czterech stronnictw, jakie odzywały się w środowiskach nie reprezentowanych w aparacie Delegatury i w Radzie Jedności Narodu.

Polityka była dla Stefana Matei sprawą ideologii, a nie rozgrywek taktycznych i to ideologii pojętej w sposób twórczy, wolny od wszelkiego schematyzmu i doktrynerstwa. Jego postawy ideowej nie można byłoby określić przy pomocy żadnego przydanego jej szyldu, ani zaliczyć go bez reszty do żadnego kierunku czy ugrupowania politycznego. Był zbyt wielką indywidualnością na to, aby można go było zakwalifikować w ten sposób. Niewątpliwie jednak jego wielka wrażliwość na problemy społeczne związane z sytuacją człowieka pracy oraz dążenie do głębszych przemian zgodnych z zasadami sprawiedliwości społecznej rozstrzygały o jego przynależności do szeroko pojętego obozu lewicy.

Sprawy te były często tematem naszych rozmów, ponieważ współpraca nasza przerodziła się z czasem w osobistą zażyłość. Odwiedzałem często Stefana Mateję poza obowiązkami służbowymi, aby pożyczać książki z jego bogatej prywatnej biblioteki oraz rozmawiać $\mathrm{z}$ nim na temat tych lektur i innych związanych z nimi problemów. Jednym ze szczególnie ważnych wątków w tych rozmowach było ustosunkowanie się do myśli programowych Sorela, które jak wiadomo, oddziałały zapładniająco na wielu naszych wybitnych myślicieli, a w okresie okupacji cieszyły się szczególną popularnością․ Starałem się już wtedy zrozumieć, co o tym rozstrzygnęło i powracam nadal często w myślach do tej kwestii. Czyżby miał to być heroizm, przypisywany przez Sorela klasie robotniczej, a tak bliski przeżyciom i doświadczeniom dni okupacji? Czy też rola mitów jako czynnika mobilizującego do wielkich społecznych działań? Czy po prostu idea oparcia porządku społecznego na syndykatach, tak bliska idei ustroju opartego na pracy, której hołdował wyraźnie nasz Departament, co znalazło wyraz w jego pracach programowych?

Stefan Mateja widział szczególną wartość koncepcji Sorela w ich swoistej czystości ideowej, w tym mianowicie, że stawiał on na samych robotników i ich organizacje jako na czynnik sprawczy, a nie na działających w ich imieniu przywódców politycznych i społecznych, wyobcowujących się w istocie z ich grona. Znajdował również upodobanie w swoistej konstrukcji głównego dzieła Sorela: Reflexions sur la violence, polegającej na wielokrotnym powracaniu do tych samych wątków myślowych z coraz szerszej perspektywy.

\footnotetext{
${ }^{7}$ Por. J. Hoppe, Wspomnienia, przyczynki i refleksje, Londyn 1976, s. 275, 281, 299.

${ }^{8}$ Por Z. Zbyszewska, Ministerstwo Polskiej Biedy, Warszawa 1983, s. 262.
} 
Rozmowy nasze dotyczyły również niekiedy stosunku do Rosji. Mateja miał wiele sentymentu dla tego wielkiego kraju i jego niespożytych sił: ,Rosji nie można pobić" powiedział bezpośrednio po napaści Hitlera na Związek Radziecki, gdy wsłuchiwaliśmy się w lokalu konspiracyjnym Wydziału Informacji BIP AK w odgłosy świeżo rozpoczętej wojny na froncie wschodnim. Był oczytany w rosyjskiej literaturze pięknej i operował nieraz zaczerpniętymi z niej przykładami czy cytatami. Miał głębokie zrozumienie dla uzasadnionych aspiracji narodu rosyjskiego, a także dla potrzeby ugruntowania przyjaźni między narodem polskim i rosyjskim oraz usuwania przeszkód na tej drodze. Chodziło mu przy tym oczywiście o istotę rzeczy, a nie o pozorne efekty i gry polityczne, mogące jedynie wypaczyć dążenia do tego celu.

W rozmowach naszych wypływały niezmiernie często różne wątki, dotyczące przyszłego obrazu polityki społecznej i prawa pracy w przyszłej Polsce. Bardziej konkretne przewidywania i zamierzenia były formułowane w przygotowywanych przez Departament dokumentach programowych i projektach aktów normatywnych. Niezależnie od tego nasuwały się jednak różne refleksje trudne do ujęcia w tę formę. Stefan Mateja mówił często o ogromie potrzeb, które będą wymagały zaspokojenia po wyniszczających przeżyciach wojny i okupacji, a także o wysiłku, jaki będzie konieczny dla odbudowy i podźwignięcia gospodarczego kraju.

Postulował w związku z tym wielką mobilizację sił o charakterze samopomocy społecznej, polegającej na świadczeniach na rzecz wspólnego dobra w zakresie odpowiadającym indywidualnym możliwościom i umiejętnościom. Wierzył, że przeżycia wojenne przyczynią się do scementowania narodu i przezwyciężenia wielu dawnych konfliktów. Postulował jednak równocześnie likwidację linii podziału stwarzających w szerokich kręgach poczucie niesprawiedliwości i krzywdy. Dotyczyło to zwłaszcza zróżnicowania uprawnień pracowniczych według kryteriów pracy fizycznej i umysłowej, a także dyskryminacji robotników rolnych. Chodziło mu jednak nie tylko o samą sytuację prawną w pracy zawodowej, lecz również o otworzenie szerokiego dostępu do oświaty na wszystkich jej szczeblach oraz o zmianę składu społecznego inteligencji, tak aby stała się ona warstwą kierowniczą, pozbawioną cech kastowych. Zgodnie ze swoją otwartą postawą Mateja uważał za celowe wykorzystywanie wszelkich obcych wzorów w takim zakresie, w jakim mogą okazać się użyteczne, bez względu na to, od kogo pochodzą. Dotyczyło to m.in. również pewnych rozwiązań techniczno-organizacyjnych stosowanych w niemieckiej polityce pracy, nie mających bezpośredniego związku z systemem politycznym.

Stefan Mateja nie był dobrym pisarzem. Formułowanie myśli na piśmie przychodziło mu z trudem, był z reguły bardzo niezadowolony ze wszystkiego, co wychodziło spod jego pióra. Należał do osób wypowiadających się inaczej: poprzez wpływ wywierany na ludzi, inspirowanie twórczych myśli, pobudzanie ożywczych dyskusji, stwarzanie klimatu sprzyjającego owocnej i harmonijnej pracy zespołowej. Był niezrównany jako kierownik prac koncepcyjno-programowych i jako 
polemista, broniący z wielką siłą argumentacji własnego stanowiska, a równocześnie otwarty na przyjmowanie wszelkich uwag, mających rzeczowe uzasadnienie.

Sympatię budziła jego postać owiana mgiełką romantyzmu i pełna niecodziennej fantazji, która cechowała jego całe postępowanie w owych latach grozy okupacyjnej. Lekceważąc wszelkie zasady konspiracji, chodził obładowany nielegalnymi dokumentami i prasą podziemną wszelkich odcieni. Odnosił się z pogodną wyrozumiałością do odstępstw od rygorów pracy konspiracyjnej, jakie wynikały z osobistych cech niektórych naszych współpracowników (zwłaszcza jednego z nich, o czym będzie jeszcze mowa poniżej). Był całkowicie zaangażowany w walkę podziemną, widząc w niej głęboki moralny sens. „Bywają takie sytuacje, w których opłacają się tylko straty" powiedział mi kiedyś w jednej z naszych przyjacielskich rozmów. Przejawiał jednak równocześnie wielką trzeźwość sądów we wszystkim, co dotyczyło rozwiązywania podstawowych problemów społecznych i pozytywnych zmian w tej dziedzinie. Był niewątpliwie jednostką nieprzeciętną, człowiekiem mądrym, odważnym i twórczym, o wyjątkowych walorach umysłu i charakteru. Odczuwałem to zawsze jako wielkie szczęście, że dane mi było z nim współpracować.

Widzieliśmy się po raz ostatni 1 sierpnia 1944 r. na krótko przed godziną „W”. Władze cywilne Polski podziemnej nie były zawiadomione o ustalonej dacie wybuchu powstania, odbywaliśmy więc rutynowy dyżur w lokalu kontaktowym, który mieścił się w mieszkaniu naszej sekretarki Alicji Eysmontówny przy ul. Marszałkowskiej 49. Stefan Mateja wyszedł z tego dyżuru około godziny 16-ej, ja pozostałem nieco dłużej i znalazłem się na terenie Śródmieścia objętym przez powstanie, w którym następnie wziąłem udział nawiązując kontakt z placówkami zorganizowanymi przez BIP AK.

Wiadomość o śmierci Matei, który został zastrzelony podczas gaszenia pożaru „Reduty Wawelskiej” w rejonie placu Narutowicza9 przyszła do Śródmieścia wkrótce po 10 sierpnia. Był to cios bolesny, który wywołał głęboki smutek i przygnębienie w kręgach Delegatury Rządu oraz wśród ludzi, którzy czuli się z nim ideowo związani. Hołd jego pamięci został oddany w nekrologu, który ukazał się w organie Delegatury, dzienniku „Rzeczpospolita Polska”"

Wkrótce po wyzwoleniu ruin Warszawy udałem się do domu, w którym mieszkał Stefan Mateja przy ul. Uniwersyteckiej 3. Dom i jego mieszkanie były zdewastowane, ale nie zostały zrujnowane ani spalone. $Z$ ogromnej masy poniszczonych i częściowo zalanych wodą papierów wybrałem to, co wydawało mi się najcenniejsze: niektóre maszynopisy oraz odbitkę korektorską jego pracy, która

\footnotetext{
${ }^{9}$ Por. A.K. Kunert, Stownik biograficzny konspiracji warszawskiej 1939-1944, t. II, Warszawa 1987, s. 126.

${ }^{10}$ „Rzeczpospolita Polska”, nr 35/107 z 24 sierpnia 1944. W nekrologu podano pseudonim Matei: Stefan Żłowski. Wspomnienie żałobne (w imieniu unionistów) pt. List z frontu ukazało się w „Kurierze Stołecznym”, nr 7 z 16 sierpnia 1944.
} 
miała być opublikowana w wydawnictwach Instytutu Spraw Społecznych w roku 1939. Uporządkowałem następnie te papiery i podjąłem starania o opublikowanie zbioru prac Stefana Matei przez Polski Instytut Służby Społecznej powstały w Łodzi w 1946 r., a kierowany przez prof. Helenę Radlińską. Zbiór ten miał się ukazać drukiem w ramach serii Biblioteka Myśli Społecznej zainicjowanej wydaniem wybranych prac Konstantego Krzeczkowskiego. Niestety na przeszkodzie publikacji stanęło stanowcze veto cenzury. Maszynopisy i wspomniana wyżej odbitka korektorska są przechowywane w Bibliotece Uniwersytetu Łódzkiego.

Krótko po wojnie i później w roku 1948, z okazji złożenia prochów Stefana Matei w Alei Zasłużonych na warszawskich Powązkach, ukazały się w prasie codziennej nekrologi i wspomnienia poświęcone jego pamięci ${ }^{11}$. Podnoszono w nich bezsporne wartości Zmarłego i podkreślano jego postępową postawę społeczną. W niektórych z nich zaznaczyła się jednak, niezgodna z prawdą, tendencja zaliczenia go do określonych szeregów i upraszczania w ten sposób obrazu jego pamięci. Od tendencji tej nie było też całkowicie wolne, piękne skądinąd, wspomnienie o Stefanie Matei opublikowane w roku 1946 przez Stanisława Gombińskiego ${ }^{12}$.

Pisząc obecnie, z innej perspektywy czasu i w warunkach umożliwiających swobodniejsze wypowiedzenie się, starałem się oddać sprawiedliwość postaci Stefana Matei oraz przedstawić prawdziwy obraz ważnego okresu jego życia.

\section{III}

Spośród współpracowników Departamentu Pracy i Opieki Społecznej szczególnie bliscy byli mi Maciej Święcicki i Jerzy Piotrowski. Z Maciejem Święcickim zetknąłem się na kilka lat przed wojną na uniwersyteckich studiach prawniczych i poprzez wspólne grona przyjacielskie. Jego żywe zainteresowania prawem pracy sprawiły, że wszedł do zespołu pracowników Ministerstwa Opieki Społecznej oraz nawiązał kontakt z Instytutem Spraw Społecznych, w którym podjął opracowanie problematyki społeczno-prawnej związków zawodowych. Uczestnik kampanii wrześniowej, wyszedł szczęśliwie z groźnej sytuacji z niezbyt ciężkimi obrażeniami, które uzasadniły jednak dłuższy pobyt w szpitalu i kwalifikację inwalidzką.

Osiadł następnie wraz z rodziną w Laskach pod Warszawą. Współpracę z Departamentem nawiązał na moją propozycję wiosną 1942 r. Uczestniczył w zebraniach odbywanych pod przewodnictwem Stefana Matei, na których

${ }^{11}$ Nekrologi w „Głosie Ludu”, nr 186 z 8 lipca 1948 i w „Życiu Warszawy”, nr 186 z 8 lipca 1948, a w „Robotniku” (nr 187 z 9 lipca 1948) wspomnienie w postaci artykułu pt. Towarzysz Stefan Mateja. W „Robotniku” ukazała się także już w roku 1945 obszerniejsza wzmianka o Stefanie Matei w ramach artykułu pt. Niesplamiony sztandar (nr 211 z 16 sierpnia 1945).

${ }^{12}$ S. Gombiński, Ś.p. Stefan Mateja, „Demokratyczny Przegląd Prawniczy”, nr 9-10, 1948, s. 51-54. Wspomniane przez Gombińskiego nowe pismo, którego wydawanie przygotowywał Stefan Mateja, miało być organem Unii Pracy. Jego redaktorem miał być pierwotnie Zygmunt Kopankiewicz; po jego aresztowaniu zadanie to przejął S. Mateja. 
kształtowały się w toku żywej wymiany zdań idee programowe Departamentu. W ramach tych zebrań przedstawił najpierw obszerniejsze opracowanie dotyczące przyszłych linii rozwojowych opieki społecznej, a następnie skupił się, zgodnie ze swymi poprzednimi zainteresowaniami, na zagadnieniach ustroju pracy.

W związku z tym wszedł w ściślejszy osobisty kontakt ze Stefanem Mateją, przygotowując pod jego kierunkiem, ale z dużym wkładem własnych myśli, różne dokumenty programowe Departamentu. Było coś fascynującego w harmonijnej i niezwykle owocnej współpracy tych dwóch ludzi o różnym rodowodzie ideologicznym, ale o podobnej wrażliwości na sprawy społeczne i podobnych, jak to oceniam z perspektywy czasu, cechach charakteru. Marksista-romantyk i konsekwentny katolik, który nieprzypadkowo odbywał służbę wojskową jako ułan, znaleźli zadziwiająco łatwo wspólny język i porozumieli się co do kierunków przebudowy ustroju pracy w przyszłej Polsce. Mateja górował w tym dialogu wiedzą i doświadczeniem oraz wynikającą stąd dojrzałością, ale Święcicki wnosił również wiele własnych myśli, a poza tym jemu przypadała przeważnie rola formułowania tekstów, które podlegały następnie dalszej obróbce.

W ten sposób powstały tezy o radach zakładowych, związkach zawodowych i izbach pracy, a następnie projekty aktów prawnych regulujących te instytucje, z których jeden, ten najdojrzalszy, dotyczący rad zakładowych, uzyskał akceptację władz Delegatury i został opublikowany w „Dzienniku Ustaw” w czasie powstania warszawskiego. Maciej Święcicki zaznaczył w ten sposób swój poważny udział w tym zakresie prac programowych Departamentu Pracy i Opieki Społecznej, który miał kluczowe znaczenie dla całości tych prac i stanowił niejako jego wizytówkę ideową.

Z Jerzym Piotrowskim zetknąłem się po raz pierwszy dopiero w roku 1939, na krótko przed wybuchem wojny, gdy przeniósł się on z Poznania do Warszawy, obejmując odpowiedzialne stanowisko w Zakładzie Ubezpieczeń Społecznych, a następnie wszedł również w kontakt z Instytutem Spraw Społecznych, podejmując na jego zlecenie opracowanie wyników ankiety na temat samorządu ubezpieczeniowego. W skład współpracowników Departamentu Pracy i Opieki Społecznej wszedł w roku 1941, nawiązując osobisty kontakt z Janem S. Jankowskim. Od tej pory datowała się nasza stale zacieśniająca się współpraca, która przybrała trwale formy z chwilą powstania zespołu opracowującego idee programowe przyszłej polityki społecznej pod przewodnictwem Stefana Matei.

Jerzy Piotrowski brał udział we wspomnianych wyżej dyskusjach, wnosząc do nich wiele trafnych sądów i ważnych spostrzeżeń opartych na jego gruntownej wiedzy socjologicznej. Następnie objął samodzielnie zakres prac koncepcyjnych, dotyczących problematyki ubezpieczeń społecznych. Spod jego pióra wyszły najpierw ogólne tezy dotyczące przyszłego rozwoju tej instytucji, które były przedmiotem wewnętrznych dyskusji w Departamencie. Z kolei opracował samodzielnie projekt dekretu o uporządkowaniu stanu prawnego w ubezpieczeniu społecznym w okresie bezpośrednio powojennym, wraz z obszernym 
uzasadnieniem, a także odrębny projekt prawa normującego sprawy ubezpieczeń społecznych na „zajętych obszarach”, tzn. na ziemiach zachodnich i północnych, co do których przewidywano, że zostaną włączone po wojnie do państwa polskiego. Przedstawił również materiały obrazujące straty instytucji ubezpieczeń społecznych w wyniku wojny i okupacji oraz związane z tym problemy odszkodowawcze. Podkreślić należy, że wszystkie te dokumenty zostały przygotowane przez Jerzego Piotrowskiego samodzielnie bądź też, jeśli chodzi o opracowania materiałowe, pozyskane jego staraniem.

Do grona ścisłych współpracowników Departamentu należał również Eugeniusz Modliński, z którym przed wojną stykałem się okazjonalnie w związku z zajmowanym przez niego stanowiskiem w Ministerstwie Opieki Społecznej, a w czasie okupacji wszedłem z nim w bliższy kontakt. Rola Modlińskiego w Departamencie była inna niż osób, o których była mowa poprzednio. Nie brał on udziału w naszych zebraniach dyskusyjnych ze względu na to, że nawiązał współpracę z Departamentem w późniejszej fazie. Nie opracowywał również żadnego wyodrębnionego działu zagadnień w ramach naszych prac koncepcyjnych. Przez jego ręce przechodziły natomiast niemal wszystkie ważniejsze nasze opracowania, które były poddawane jego osądowi zarówno pod względem merytorycznym jak i formalnym. Utrzymywałem w związku z tym kontakt $\mathrm{z}$ Eugeniuszem Modlińskim, przekazując mu różne dokumenty Departamentu oraz odbierając jego uwagi, a także omawiając je z nim bezpośrednio. Był to w przeważającej mierze kontakt osobisty w miejscu pracy Modlińskiego w Ubezpieczalni Społecznej, która mieściła się wówczas przy ul. Smulikowskiego w gmachu ZNP. To pominięcie zwykłej konspiracyjnej drogi (za pośrednictwem łączniczek, skrzynek itp.) sprzyjało bezpośredniemu porozumieniu, a przy tym było uzasadnione charakterem naszej współpracy, która przybierała coraz bardziej formy wymiany myśli na gruncie przyjaznych stosunków. Funkcja Eugeniusza Modlińskiego w Departamencie została określona w jego organizacyjnej strukturze jako „referat ogólny”. Jego opinie były wysoko cenione przez Stefana Mateję ${ }^{13}$.

Współpracownikiem merytorycznym Departamentu był również Marian Baran, który wszedł w kontakt z nami na przełomie 1943 i 1944 r. i przeniósł się w związku z tym z Krakowa do Warszawy. Był on znawcą zagadnień opieki społecznej, a plonem jego prac było przygotowanie projektu dekretu o utworzeniu Polskiego

${ }^{13}$ Z Maciejem Święcickim, Jerzy Piotrowskim i Eugeniuszem Modlińskim łączyła mnie po wojnie przez dłuższe lata osobista przyjaźń i ścisła współpraca na gruncie naukowym, wszyscy trzej zostali bowiem profesorami na wyższych uczelniach. Poniżej (podaję opublikowane przeze mnie wspomnienia, uwzględniające również okres okupacji: Maciej Święcicki (1913-1971), „Państwo i Prawo" nr 2/1972, s. 109-112 oraz Księga Pamiattowa. Studia z prawa pracy, SGPiS, Warszawa (w druku); Jerzy Piotrowski (1907-1983), „Polityka Społeczna” 1984, nr 1, s. 39 i n. oraz „Studia i Materiały z Historii Ubezpieczeń Społecznych w Polsce" z. 4, Warszawa 1986, s. 177-182; ibidem opublikowano fragment opracowania programowego Jerzego Piotrowskiego z czasu wojny (s. 183-185); Eugeniusz Modliński (1903-1984), „Polityka Społeczna” 1984, nr 4, s. 39 i n. 
Komitetu Samopomocy Społecznej, który w naszej koncepcji miał powstać bezpośrednio po wojnie w miejsce RGO, a także projektu statutu tej instytucji.

Osobna uwaga należy się współpracownikom techniczno-administracyjnym, z którymi utrzymywałem szczególnie bliski kontakt, ponieważ do mnie należała organizacyjna strona działalności Departamentu. Rozwój tej działalności, zwłaszcza akcji opieki czynnej, sprawił, że zaszła potrzeba włączenia do obsady personalnej Departamentu osoby zajmującej się prowadzeniem kasy i uproszczonej księgowości dla utrzymania w należytym porządku gospodarki finansowej. Obowiązki te objął w roku 1943 Marian, dobry znajomy Stefana Matei z Kielc, gdzie zajmował poprzednio stanowisko kierownicze w bankowości. Był to człowiek nie tylko fachowy lecz również obowiązkowy i sumienny, tak że współpraca z nim układała się bardzo harmonijnie. $Z$ jednym tylko zastrzeżeniem: mianowicie co pewien czas, niezbyt często, ale jednak wystąpiło to w okresie naszej półtorarocznej współpracy parokrotnie, przychodził na niego „amok”: znikał wówczas bez uprzedzenia na 2-3 dni, oddając się w tym czasie uciechom życia, po czym podejmował znów swe obowiązki i wszystko wracało do normy. Odskoki te nie pasowały zupełnie do jego codziennej sylwetki, człowieka zorganizowanego i zrównoważonego, były mu jednak najwyraźniej potrzebne jako forma odprężenia, równoważącego napięcia życia okupacyjnego pod wysokim ciśnieniem. Ujawniały one również jakby drugą stronę jego natury, pełną niespodziewanej fantazji, gdy potrafił np. skłonić motorniczego tramwaju do odwiezienia go pod sam dom poza normalną trasą, po godzinie policyjnej. Nietrudno sobie wyobrazić zakłócenia, jakie w naszej pracy konspiracyjnej wprowadzały nagłe zniknięcia Mariana (zwłaszcza za pierwszym razem!): zmiana lokali, przerzucanie pieniędzy i dokumentów itp. Później przestaliśmy już reagować tak nerwowo, a Stefan Mateja, któremu przedstawiałem tę sprawę, okazywał w stosunku do niej dużą wyrozumiałość i pobłażliwość.

Szczególnie ważną komórkę organizacyjną Departamentu stanowił sekretariat (kryptonim: „Biuro”) i cały powiązany z nim system łączności. Na czele tej komórki stała Alicja Eysmontówna („Irena”) prowadząc ją wzorowo, z dużym nakładem starań o sprawność, bezpieczeństwo i niezawodność obiegu dokumentów. Po długich latach jedna z najbliższych naszych współpracowniczek - łączniczka Departamentu, Hanna Pachnowska-Wałkówska („Ewa”), pisała wspominając: „Ja naprawdę lubiłam tamto »biuro« na Wspólnej, gdzie każdego ranka Pani Irena (nigdy nie potrafię nazywać Jej inaczej) z niezmąconym spokojem rozdzielała pocztę, ustalała trasę i jej dokładne godziny. To naprawdę dziwne, że w centrum tamtej Warszawy, w konspiracyjnym lokalu, miało się poczucie bezpiecznego azylu. Nigdy ani przez chwilę nie miałam wątpliwości, że tam nie będzie »kotła«. Myślę, że właśnie postawa Pani Ireny, jej spokojna pewność dobrej roboty, nie była tu bez znaczenia" (wspomnienia w formie listu z 11 marca 1987).

Taką też pozostała Alicja Eysmontówna w mej pamięci: sumienna, obowiązkowa i zaangażowana, niezawodna w organizowaniu codziennej roboty, od której 
dobrego wykonania zależało tak wiele, jakkolwiek nie dawała ona bezpośrednio większych satysfakcji. W całym okresie sprawowania przeze mnie funkcji zastępcy dyrektora Departamentu Alicja Eysmontówna należała do moich najbliższych współpracowników. W wielu trudnych sytuacjach była mi bezpośrednio pomocna; z perspektywy czasu zdaję sobie tym bardziej sprawę, jak wiele miałem jej do zawdzięczenia i ta świadomość dominuje w moim wspomnieniu. W podobny sposób wspominani inną naszą współpracowniczkę, wchodzącą w skład sekretariatu, Janinę Gadomską („Wandę”). Reprezentowała ona w naszym gronie nieco starsze pokolenie: dawna członkini „Zetu”, uczestniczka strajków szkolnych z roku 1905, zaprawiona w pracy konspiracyjnej i bezwzględnie oddana sprawie, a przy tym pełna osobistego uroku, była niezawodna w działaniu i zawsze gotowa do wszelkich wysiłków i poświęceń, jakich mogło wymagać uczestnictwo w podziemnej robocie. Właściwe jej roztargnienie nie upośledzało sprawności działania. Odznaczała się również odwagą, co miało się okazać w trudnych, tragicznych dniach powstania warszawskiego.

\section{IV}

Wybuch powstania położył kres opisanym wyżej formom działalności Departamentu. Zaskoczeni tym faktem, podobnie jak cała Delegatura, nie mieliśmy możności odpowiednio się przygotować. W związku z tym rozproszyło się grono współpracowników Departamentu i porwały się sieci łączności, które tylko w pewnej części udało się następnie odbudować. Śmierć Stefana Matei, izolowanego od początku na beznadziejnej reducie w rejonie Placu Narutowicza, była szczególnie ciężkim ciosem.

W atmosferze pierwszych dni powstania znaczenie spraw „cywilnych”, jakimi zajmowaliśmy się dotychczas, schodziło z natury rzeczy na dalszy plan, rodziła się natomiast potrzeba włączenia się do formacji walczących. Dla mnie formacją tą stała się radiostacja „Anna”, do której wszedłem w sposób niejako naturalny, dzięki poprzednim powiązaniom z Biurem Informacji i Propagandy AK. I tak patrole informacyjne i obsługiwanie stanowisk obserwacyjnych zastąpiły dla mnie dawne formy aktywności; później wszedłem również $\mathrm{w}$ kontakt $\mathrm{z}$ ośrodkiem centralnym VI Oddziału Sztabu AK mieszczącym się w gmachu PKO przy ul. Świętokrzyskiej.

Stopniowo skupiała się jednak na nowo grupka współpracowników Departamentu. Należały do nich Alicja Eysmontówna, Janina Gadomska, która w początkowych dniach powstania pracowała jako sanitariuszka w szpitalu przy ul. Świętokrzyskiej; później także Marian Baran, wycieńczony i schorowany po przejściu kanałami ze Starego Miasta do Śródmieścia. Ta grupa pozostawała następnie w ścisłej łączności do ostatnich dni powstania.

Zarysowały się też sprawy, wymagające ze względu na swój charakter zainteresowania ze strony Departamentu. Pierwszą z nich była konieczność stworzenia 
form zorganizowanej samopomocy dla osób zmuszonych do opuszczenia swych miejsc zamieszkania i szukania schronienia na terenie Śródmieścia. Formy takie powstawały w sposób samorzutny i polegały nie tylko na zapewnieniu azylu, lecz również pomocy w zakresie wyżywienia, na co w pierwszym okresie powstania pozwalały jeszcze istniejące zasoby. Miałem możność zapoznania się ze szczególnie wartościowymi przejawami takiego działania. Departament nie miał w tym zakresie żadnych możliwości udzielenia organizacyjnej ani rzeczowej pomocy, pozostawała jedynie droga oddziaływania moralnego w kierunku mobilizowania postaw solidarności i samopomocy społecznej. W tym duchu ogłosiłem odpowiednią odezwę do mieszkańców Śódmieścia na łamach biuletynu wydawanego przez radiostację „Anna”, pod redakcją Władysława Bartoszewskiego ${ }^{14}$.

Następna sprawa wiązała się ściśle z poprzednim nurtem prac Departamentu, polegających na przygotowywaniu projektów aktów legislacyjnych. Jeden z tych aktów, dekret o radach zakładowych, został przyjęty uchwałą Krajowej Rady Ministrów i zakwalifikowany do opublikowania w „Dzienniku Ustaw”, który postanowiono wydawać w czasie powstania. Ze zrozumiałych względów interesowałem się tą sprawą. Próbowałem też naiwnie wpłynąć jeszcze na pewne poprawki w tekście wspomnianego dekretu, który, jako wynik pewnego kompromisu w łonie Delegatury, nie całkowicie nas w Departamencie zadowalał. Próby te nie mogły oczywiście być skuteczne, co wyjaśniło się w toku kontaktu, jaki nawiązałem z Adamem Bieniem, który, jako pierwszy zastępca Delegata Rządu, działał w tym czasie w jego imieniu na terenie Śódmieścia. Po ukazaniu się nr 2 „Dziennika Ustaw”, w którym opublikowany został tekst dekretu o radach zakładowych ${ }^{15}$, napisałem artykuł wyjaśniający jego zasady, wydrukowany następnie w organie Delegatury „Rzeczpospolita Polska”"16.

Inne sprawy, takie jak kontakt z instytucjami należącymi do naszego resortu, a mieszczącymi się na terenie objętym powstaniem oraz z delegaturami dzielnicowymi działającymi w różnych rejonach miasta, zwłaszcza w Śródmieściu, miały już wtórny charakter, nie było bowiem w tym zakresie wiele do zrobienia. Przez pewien czas rezydowałem jednak w związku z tym w lokalu oddanym do dyspozycji Departamentu przy ul. Sienkiewicza 4 . Warunki tej pracy były zupełnie nienormalne, gdyż ciężki ostrzał tej części Śródmieścia sprawiał, że lokal ten ulegał postępującej dewastacji. Dotrzymywała mi w tym czasie po bohatersku kroku Janina Gadomska, której pełna ofiarności postawa była mi cenną pomocą.

${ }^{14}$ „Wiadomości z Miasta i Wiadomości Radiowe”, nr 7 z 6 sierpnia 1944. Świadectwem drugiego, równoległego nurtu mojej działalności w tym czasie był opublikowany w tychże „Wiadomościach” (nr 11 z 8 sierpnia 1944) mój reportaż pt. Na ulicy Piusa przed gmachem Pasty.

${ }^{15}$ Rozporządzenie Krajowej Rady Ministrów z dnia 1 sierpnia 1944 r. o radach zakładowych, „Dziennik Ustaw Rzeczypospolitej Polskiej” cz. III, nr 2 z 2 sierpnia 1944, poz. 16. O kontrowersjach w łonie Delegatury, dotyczących treści tego aktu prawnego pisze A. Bień, Bóg jest wyżej, dom jest dalej, „Przedświt”, Warszawa, s. 71 i 101.

${ }^{16}$ Rady Zakładowe, „Rzeczpospolita Polska”, nr 38/110 z 27 sierpnia 1944. 
W tymże lokalu odwiedził mnie w końcu sierpnia Franciszek Białas zawiadamiając, że zostało mu powierzone stanowisko dyrektora Departamentu Pracy i Opieki Społecznej, osierocone przez śmierć Stefana Matei. Wyjaśnił przy tym, że tylko wyjątkowo, ze względu na szczególną pozycję Matei, stanowisko to mogło być zajmowane przez człowieka nie należącego do żadnego ze stronnictw, na których opierała się struktura Delegatury Rządu. Obecnie musiał tu jednak znaleźć zastosowanie klucz polityczny, według którego przypadło ono Białasowi jako przedstawicielowi PPS-WRN. Mnie pozostawiono nadal funkcję zastępcy dyrektora; coraz bardziej jednak stawało się dla mnie rzeczą jasną, że moja dotychczasowa rola w Departamencie stanowi zamknięty rozdział i że nigdy już nie będę mógł rozwijać w nim takiej działalności, jaka była moim udziałem w okresie przedpowstańczym ${ }^{17}$. Najszczęśliwszym dla mnie rozwiązaniem byłoby chyba w tych okolicznościach zdecydowanie się na pójście do niewoli: sugerowano mi to wraz z propozycją awansu do stopnia oficerskiego; była to jednak dla mnie propozycja trudna do przyjęcia.

Byłem świadom obowiązków wobec grona naszych współpracowników, którzy pozostawali ze mną nadal w kontakcie i tych, których spodziewaliśmy się odszukać po powstaniu, ewentualnie wobec członków ich rodzin. Za swój obowiązek uważałem ponadto zabezpieczenie dokumentów, obrazujących dorobek prac koncepcyjnych Departamentu, których najważniejszy zestaw przechowywaliśmy cały czas pieczołowicie. To było ostatnie zadanie, jakie miała do wykonania nasza czteroosobowa grupa we wspomnianym poprzednio składzie.

Powstanie w sposób oczywisty dogorywało. Kończyła się epopeja potwornego nieraz, a jednak wspaniałego życia na skrawku wolnej ziemi, na którym można było w szczególny sposób czuć się bezpiecznym: od zagrożeń, jakie stwarzał poprzednio terror okupacyjny. Bezmierna ofiara cierpień i krwi miała okazać się raz jeszcze daremna. Tracił bezpośredni sens cały poprzedni trud przygotowywania planów na okres mający zapoczątkować nową fazę życia narodu, po uwolnieniu od okupacji hitlerowskiej. Przenikało zwolna do naszej świadomości, że prace nasze nie będą w chwili ostatecznego przełomu bezpośrednio przydatne. Mieliśmy; jednak przekonanie, że zawiera się w nich ładunek myśli, do których być może w przyszłości wypadnie powrócić. A w każdym razie, że prace te będą miały wartość jako dokument historyczny, odzwierciedlający dążenia właściwe znacznemu odłamowi postępowej myśli społecznej.

Aby te materiały przechować, należało powierzyć je ziemi. Powinno to być jednak dokonane bez niepotrzebnych świadków. W tym celu nasza grupa opóźniła swój termin wyjścia z miasta po powstaniu do czasu, aż wszyscy lokatorzy domu naszego pobytu go opuszczą. W nocy z 5 na 6 października 1944 r. dom

\footnotetext{
${ }^{17}$ Utrzymała się jednak nadal po powstaniu moja więź organizacyjna z Departamentem, który rozwinął w tym czasie szeroką akcję opiekuńczą, zwłaszcza w stosunku do ludności wysiedlonej z Warszawy.
} 
opustoszał już całkowicie. W zupełnej pustce, ciemności i ciszy przystąpiliśmy do zakopywania na skwerku podwórza tej kamienicy naszych dokumentów. W pewnym momencie odezwał się jednak odgłos przypominający o życiu, jakie do niedawna pulsowało $\mathrm{w}$ tym wielkim domu i jakie nie miało już więcej do niego powrócić. Był to dźwięk zegarów, które w licznych opuszczonych już mieszkaniach, o pustych otworach okiennych, zaczęły kolejno wybijać północ. Było coś głęboko przejmującego w tym echu jakby zza grobu, ostatnim świadectwie minionego życia w mieście skazanym na zagładę. Symbolizowało to w sposób bardziej wymowny tragizm przeżywanych chwil niż niejedno z bezpośrednich groźnych wydarzeń. Odczuliśmy to wszyscy głęboko.

Nieprędko przyszedł sposobny czas, aby powrócić do tamtych dokumentów i materiałów oraz podjąć próbę ich opracowania. Gdy jednak zdecydowałem się to uczynić, rodzina mego zmarłego już od dawna przyjaciela, Macieja Święcickiego, przekazała mi dodatkowo tekę papierów, które zostały przez niego przechowane pod Warszawą. Odczułem to jako podanie mi przez niego pomocnej dłoni i dodatkową zachętę. A w toku tej mojej pracy narzuciła mi się potrzeba uzupełnienia jej osobistymi wspomnieniami o ludziach mi bliskich, a nieżyjących, którzy mieli w działalności tamtych lat szczególny udział. W ten sposób powstał niniejszy szkic. 


\section{Bibliografia}

Ajnenkiel A., Położenie prawne robotników rolnych w Polsce (1918-1939), Warszawa 1962.

Ajzner S., Zwiąek Związów Zawodowych (1931-1939), Warszawa 1979.

Bezrobocie wśród chlopów. Instytut Gospodarstwa Społecznego, Warszawa 1939.

Bień A., Bóg jest wyżej - dom jest dalej (1939-1949), Warszawa 1991.

Blanc-Jouvan X., Les rapports collectifs aux Etats Unis, Grenoble 1956.

Brodowski L., Samorząd rad zakładowych, Częstochowa 1947.

Brun A., Galland H., Droi du Travail, Paris 1978.

Däubler W., Das Arbeitsrecht, Reinbek bei Hamburg 1976.

Däubler W., Das Grundrecht auf Mitbestimmung, Frankfurt am Main 1973.

Fenichel Z., Polskie prawo urzędnicze a prawo pracowników najemnych, „Praca i Opieka Społeczna” 1930, $\mathrm{nr} 4$.

Fenichel Z., Zarys polskiego prawa robotniczego, Kraków 1930.

Friszke A., O ksztalt Niepodlegtej, Warszawa 1989.

Fundusz Pracy w latach 1933-1934, Warszawa 1934.

Grabski S., Ku lepszej Polsce, Warszawa 1938.

Hoppe J., Samorzą Pracy, Warszawa 1932.

Hoppe J., Wspomnienia, przyczynki, refleksje, Londyn 1972.

Hueck A., Nipperdey H.C., Lehrbuch des Arbeitsrechts, t. II, Mannheim, Berlin, Leipzig 1930.

Instytut Spraw Spolecznych przy Asfaltowej, [w:] Wspomnienia warszawskich peperowców, Warszawa 1963.

Jaśkiewicz W., Studia nad sytuacja prawna pracowników państwowych, t. I, Poznań 1961.

Jaworski W.L., Ankieta o Konstytucji, Warszawa 1924.

Kabaj M., Funkcje wartościowania pracy, [w:] Metody wartościowania pracy, Warszawa 1979.

Klarner C., Zadania i wytyczne państwowej polityki gospodarczej, Warszawa 1932.

Klott M., Ustawodawstwo społeczne a rzeczywistość, „Przegląd Ekonomiczny” (Lwów) 1937, t. XVIII, nr 87-90.

Korboński S., Polskie Państwo [Podziemne, Bydgoszcz 1990].

Krzeczkowski K., Idee przewodnie ubezpieczeń społecznych, Warszawa 1936.

Kwiatkowski E., Dysproporcje [Rzecz o Polsce przeszłej i obecnej], Warszawa 1989.

Landau W., Izby Pracy, Warszawa 1932.

Lange O., Wizje gospodarki socjalistycznej (Wybór pism), Warszawa 1985.

Leinwand A., Tadeusz Szturm de Sztrem, Warszawa 1987.

Lewandowska S., Polska konspiracyjna prasa informacyjno-polityczna 1939-1945, Warszawa 1982.

Malański J., Pracownicze zwiazki zawodowe w Polsce, Warszawa 1934.

Mateja S., Opieka nad pracownikiem jako obowiązek pracodawcy, maszynopis, BUŁ. 
Mateja S., Tendencje prawa pracy, „Praca i Opieka Społeczna” 1934, nr 4.

Młodzież sięga po pracę. Instytut Sprawa Społecznych, Warszawa 1938.

Nowacki J., Ubezpieczenia na wypadek braku pracy, [w:] Rozwój ubezpieczeń społecznych w Polsce, Warszawa 1991.

Polityka Społeczna Państwa Polskiego (1918-1935), Warszawa 1935.

Ossowski S., Ku nowym formom życia społecznego, Warszawa 1947.

Piotrowski J., Od ubezpieczenia chorobowego do powszechnej służby zdrowia, Łódź 1948.

Rybarski R., Program gospodarczy, Warszawa 1932.

Rychliński S., Zasadnicze kierunki robotniczego ruchu zawodowego w Polsce, Warszawa 1929.

Rygier H., Izby Pracy. Projekt ustawy i uzasadnienia, Warszawa 1932.

Rzepecki J., Wspomnienia i przyczynki historyczne, Warszawa 1983.

Święcicki M., Instytucje polskiego prawa pracy w latach 1918-1939, Warszawa 1960.

Święcicki M., Prawo stosunku pracy, Częstochowa 1949.

Święcicki M., Rady zaktadowe jako organy ruchu zawodowego, „Państwo i Prawo” 1940, nr 9/10.

Szubert W., Konstanty Krzeczkowski jako polityk społeczny, [w:] K. Krzeczkowski, Polityka spoteczna. Wybór pism, Łódź 1947, s. LVII-LVIII.

Szubert W., Nowe drogi polityki społecznej, „Myśl Współczesna” 1947, nr 11.

Szubert W., O charakterze prawnym stosunku pracy, „Państwo i Prawo” 1964, nr 7.

Szubert W., Ujednolicenie prawa pracy w polskiej myśli prawniczej lat międzywojennych i okresu wojny, „Państwo i Prawo” 1991, nr 4.

Szubert W., Uktady zbiorowe pracy, Warszawa 1960.

Szubert W., Zastużeni dla rozwoju ubezpieczeń społecznych. Jerzy Piotrowski (1907-1983), „Studia i Materiały z Historii Ubezpieczeń Społecznych w Polsce” (Warszawa) 1986, z. 4, s. 178-179.

Tomicki J., Polska Partia Socjalistyczna 1892-1948, Warszawa 1983.

Trójgłos o Instytucie Spraw Społecznych w Warszawie z okresu okupacji, „Studia i Materiały z Historii Ubezpieczeń Społecznych w Polsce" (Warszawa) 1986, z. 4, s. 157-176.

Verdier J.M., Syndicats, Paris 1966.

Wengierow J.G., Izby Pracownicze, Warszawa 1934.

Wengierow J.G., Przedstawicielstwo pracownicze a państwo, Warszawa 1935.

Zaleski Z., Rola sądów pracy w zakresie realizowania zasad i ksztattowania wytycznych polityki społecznej państwa, „Praca i Opieka Społeczna” 1930, nr 1.

Zbyszewska Z., Ministerstwo polskiej biedy, Warszawa 1983.

Zientara B., Mączak A., Ihnatowicz I., Landau Z., Dzieje gospodarcze Polski do 1939 r., Warszawa 1965. 